\title{
ALBIAN-CENOMANIAN FORAMINIFERA IN NORTHEASTERN BRITISH COLUMBIA AND WESTERN ALBERTA: \\ PALEOECOLOGY AND INTEGRATION OF BIOSTRATIGRAPHY WITH ALLOSTRATIGRAPHY
}

\section{David Mans}

A thesis submitted to the Faculty of Graduate Studies in partial fulfillment of the requirements for the degree of Master of Science

\author{
Department of Earth Sciences \\ Carleton University \\ Ottawa-Carleton Geoscience Centre \\ Ottawa, Ontario
}

September 2007

(C) Copyright 2007, David Mans 


$\begin{array}{ll}\begin{array}{l}\text { Library and } \\ \text { Archives Canada }\end{array} & \begin{array}{l}\text { Bibliothèque et } \\ \text { Archives Canada }\end{array} \\ \begin{array}{l}\text { Published Heritage } \\ \text { Branch }\end{array} & \begin{array}{l}\text { Direction du } \\ \text { Patrimoine de l'édition }\end{array} \\ \begin{array}{l}\text { 395 Wellington Street } \\ \text { Ottawa ON K1A ON4 }\end{array} & \begin{array}{l}\text { 395, rue Wellington } \\ \text { Ottawa ON K1A ON4 } \\ \text { Canada }\end{array}\end{array}$

Your file Votre référence ISBN: 978-0-494-33704-2 Our file Notre référence ISBN: 978-0-494-33704-2

NOTICE:

The author has granted a nonexclusive license allowing Library and Archives Canada to reproduce, publish, archive, preserve, conserve, communicate to the public by telecommunication or on the Internet, loan, distribute and sell theses worldwide, for commercial or noncommercial purposes, in microform, paper, electronic and/or any other formats.

The author retains copyright ownership and moral rights in this thesis. Neither the thesis nor substantial extracts from it may be printed or otherwise reproduced without the author's permission.
AVIS:

L'auteur a accordé une licence non exclusive permettant à la Bibliothèque et Archives Canada de reproduire, publier, archiver, sauvegarder, conserver, transmettre au public par télécommunication ou par l'Internet, prêter, distribuer et vendre des thèses partout dans le monde, à des fins commerciales ou autres, sur support microforme, papier, électronique et/ou autres formats.

L'auteur conserve la propriété du droit d'auteur et des droits moraux qui protège cette thèse. $\mathrm{Ni}$ la thèse ni des extraits substantiels de celle-ci ne doivent être imprimés ou autrement reproduits sans son autorisation.
In compliance with the Canadian

Privacy Act some supporting forms may have been removed from this thesis.

While these forms may be included in the document page count, their removal does not represent any loss of content from the thesis.
Conformément à la loi canadienne sur la protection de la vie privée, quelques formulaires secondaires ont été enlevés de cette thèse.

Bien que ces formulaires aient inclus dans la pagination, il n'y aura aucun contenu manquant.

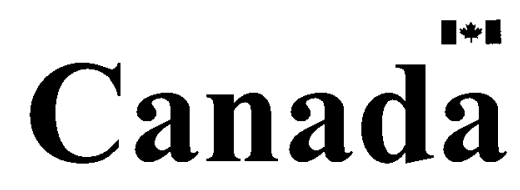




\begin{abstract}
The Rocky Mountain foredeep in northeastern British Columbia and northwestern Alberta preserves an expanded Albian to Cenomanian interval in outcrop and subsurface that documents a nearly complete sea-level record of the Western Interior Sea at that time. Current foraminiferal subzonations that were based on multiple short stratigraphic intervals and are linked to lithostratigraphic frameworks make correlations to areas of less accommodation space to the east and south problematic. An extensive subsurface and outcrop database based on sedimentology and wireline logs in this region resulted recently in a new allostratigraphic framework that forms the basis for new biostratigraphic correlations. Micropaleontological analysis of a complete section at Deadhorse Meadows has led to a new foraminiferal zonation where faunal changes are linked to allostratigraphic surfaces. This zonation was tested in previously used outcrops and lateral faunal distribution correlates remarkably well to the new allomember architecture. Latest Albian faunas represent highstand and falling stage systems tracts, where maximum abundances occur in the middle of the deposits associated with maximum flooding intervals. Cenomanian strata also represent transgressive system tracts associated with the Greenhorn transgression.

Latest Albian foraminiferal assemblages in this region consist almost entirely of benthic agglutinated species controlled by cool, low salinity waters of the Mowry Sea. Distribution of morphotypes, related to feeding strategies indicate lower shoreface to marginal marine environments confirming lower paleosalinities and paleoenvironmental and paleogeographic interpretations based on sediment facies. Lowest Cenomanian strata are barren of foraminifera due to bottom water anoxia. An increase in the oxygen
\end{abstract}


minimum zone resulted in increased organic matter entering the water column during rapid transgression. As the basin deepened during continued Greenhorn transgression uncoiled and serial morphotypes began to colonize the mudstone dominated facies indicating normal marine paleosalinties and the return of bottom water oxygenation. 


\section{ACKNOWLEDGEMENTS}

My sincere thanks go out to my advisor Dr. Claudia Schröder-Adams for a great M.Sc. project along with her guidance and support throughout the length of this study. I would especially like to thank her for her time and energy in the field and especially her enthusiasm for geology. Research funding for this project was supplied by a NSERC Discovery Grant to Dr. Claudia Schröder-Adams. Additional funding was made possible by an AAPG Grant and the William V. Sliter Student Research Award. I would like to thank Guy Plint and Xavier Roca for their invaluable help in understanding the allostratigraphic framework, section and core descriptions and samples for foraminiferal analysis. Thanks to my colleagues at Carleton University, especially Aaron Phillips. My discussions with him were always a pleasure (if somewhat drawn out) and made for a better working environment, good humour and good times. I owe all kinds of obligation to my parents and my brother for their unlimited and unconditional love; especially their encouragement to get a job. Last but not least, I shall be forever indebted to Jaya and Vibha Dixit. I would like to thank Vibha for giving me a home away from home, with her generous hospitality, laughter, friendship and out of this world cooking. To Jaya for her everlasting love, inspiration, sacrifice, encouragement, laughter and tears, which have certainly contributed a lot to the successful completion of this thesis. 


\section{TABLE OF CONTENTS}

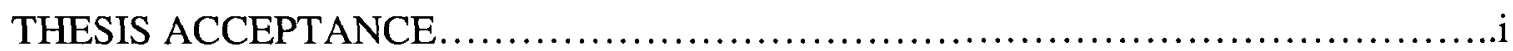

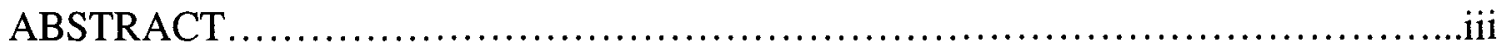

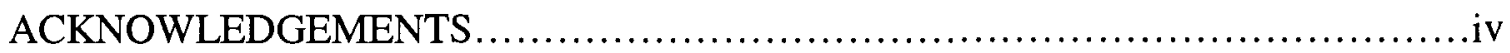

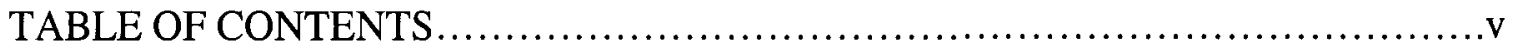

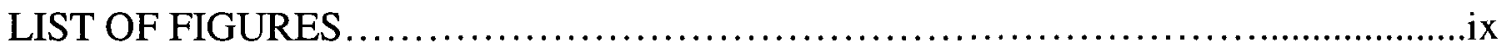

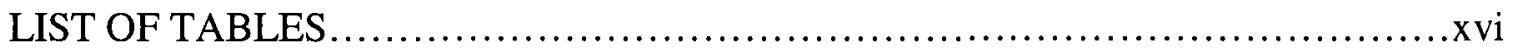

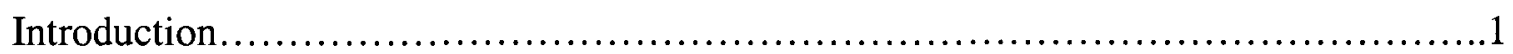

Materials and Methods.........................................................

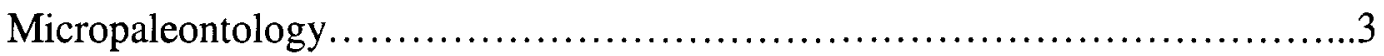

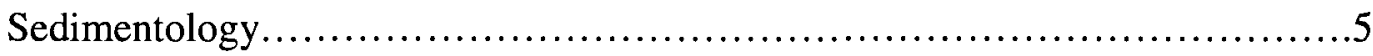

Wireline well $\log$ correlations...........................................5

Geologic setting ..............................................................

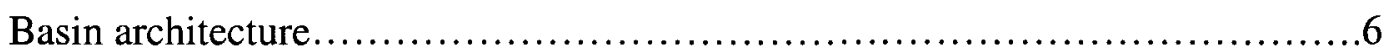

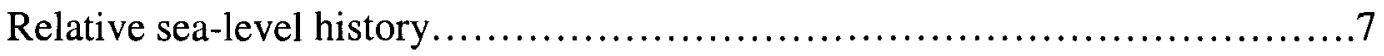

Structure.....................................................................

Lithostratigraphy.................................................. 10

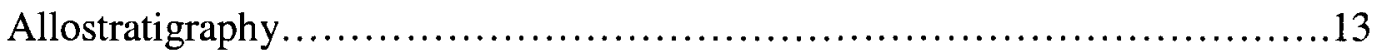

Foraminiferal biostratigraphy......................................... 16

Biostratigraphic Challenges...............................................23

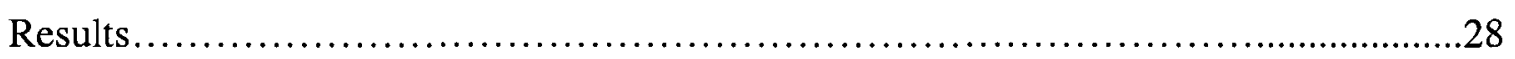

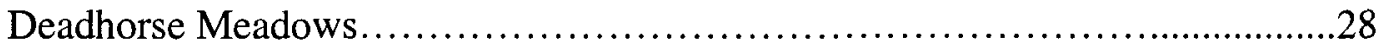


Lithology.

Micropaleontology ............................................30

Haplophragmoides postis goodrichi Zone......................35

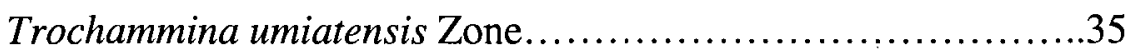

Haplophragmium swareni Zone...........................37

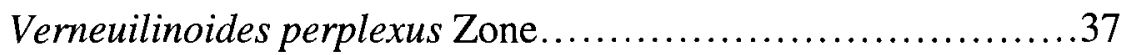

Ammobaculites gravenori Subzone.............................37

Gaudryina irenensis Subzone.............................. 38

Nickerson Creek.........................................................

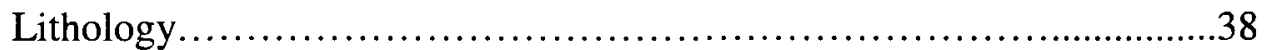

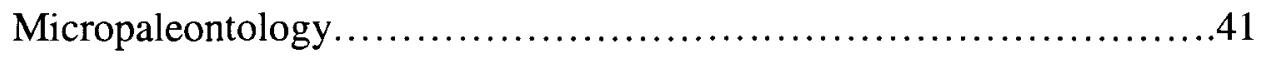

Sulphur River....................................................41

Lithology.........................................................41

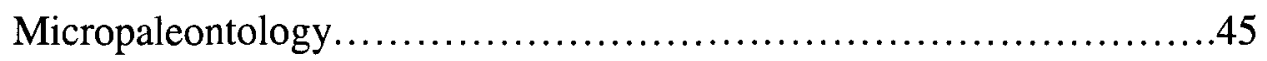

Mount Belcourt.....................................................45

Lithology........................................................... 45

Micropaleontology..............................................49

Haplophragmoides multiplum Zone.........................49

Hasler Creek............................................................. 51

Lithology...................................................53

Micropaleontology $\ldots \ldots \ldots \ldots \ldots \ldots \ldots \ldots \ldots \ldots \ldots \ldots \ldots \ldots \ldots \ldots \ldots . \ldots \ldots$

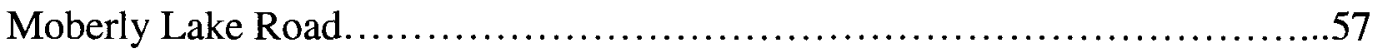

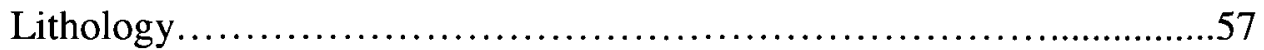


Halfway River....................................................67

Lithology.........................................................67

Micropaleontology..........................................67

Cores........................................................... 71

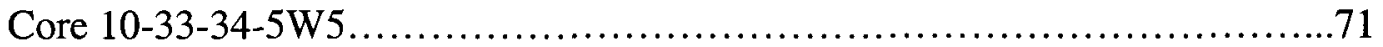

Lithology..................................................... 71

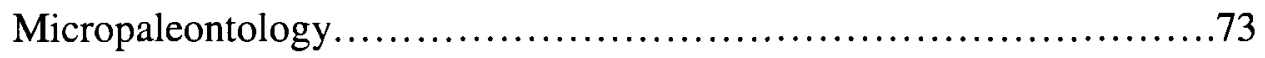

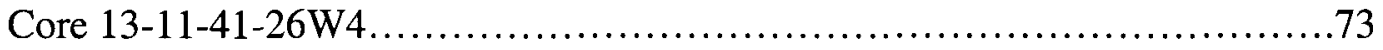

Lithology..........................................................73

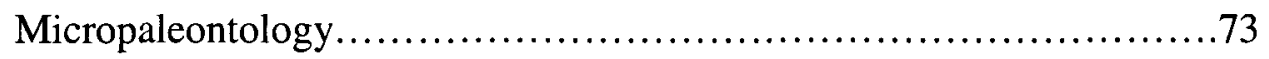

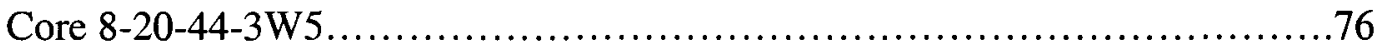

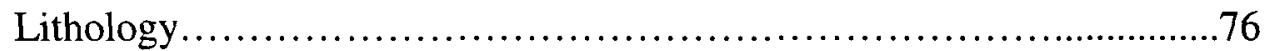

Micropaleontology ...........................................76

Wireline $\log$ correlations........................................... 76

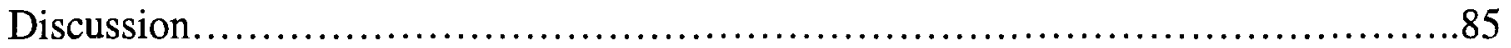

A biostratigraphic zonal scheme using allostratigraphy $\ldots \ldots \ldots \ldots \ldots \ldots \ldots \ldots . \ldots 5$

Lithostratigraphic vs. allostratigraphic biostratigraphy...............88

Haplophragmoides multiplum Zone............................90

Haplophragmoides postis goodrichi Zone........................92

Trochammina umiatensis Zone...............................93

Haplophragmium swareni Zone............................93

Verneuilina canadensis Zone....................................94 
Foraminifera as paleoenvironmental proxies in sequence stratigraphy.

Paleoshorelines.

100

Use of morphotypes............................................... 101

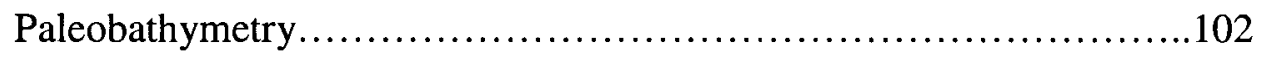

Paleosalinity.................................................111

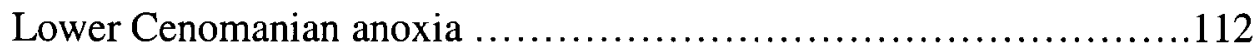

Application beyond the study area....................................116

Conclusions.................................................................... 19

Systematics............................................................. 122

References............................................................ 146

Plates......................................................................... 161

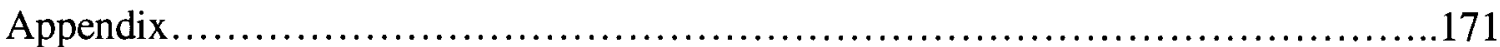




\section{LIST OF FIGURES}

Figure 1. Location map of study area showing localities of sampled outcrops and wells with the Imperial Spirit River Well (Stritch et al. 1999) for reference. Green shaded shaded areas are national parks and the grey shaded area represents the Peace River Arch structure............................................ 2

Figure 2. Global transgressive-regressive cycles and transgressive-regressive cycles in northwest Alberta of the WCSB during the Cretaceous (Aptian to Santonian) and radiometric ages at stage boundaries. Modified after Kauffman (1977) and Obradovich (1993).

Figure 3. Regional stratigraphic nomenclature for the study area in northeast British Columbia and northwest Alberta. Modified from Stott (1982), Stelck and Koke (1987), Bloch et al. (1993) and Schröder-Adams and Pedersen (2003)...11

Figure 4. Allostratigraphic cross-section for western Alberta (Roca 2007). Erosional surfaces are labelled on the left and right margin of the cross-section and allomembers are labelled between erosional surfaces. Allomembers represent lithostratigraphic strata from the Viking and Westgate formations.

Figure 5. Difference in lithostratigraphy and allostratigraphy of the Lower Colorado Group (Roca, 2007)

Figure 6. Foraminiferal zones and subzones of Aptian to lower Cenomanian stages, macrofossil zones and their relationship with sea-level changes (modified after Schröder-Adams and Pedersen 2003). 
Figure 7. Species 1. Haplophragmoides postis goodrichi, 2. Haplophragmoides linki and 3. Haplophragmoides multiplum are well defined and easily identified taxonomically. Species 4-10 are all variations of Haplophragmoides postis found within the PR-2001-G3 sample from Moberly Lake Road. Note the various degree of distortion, overgrowth and silicification........................26

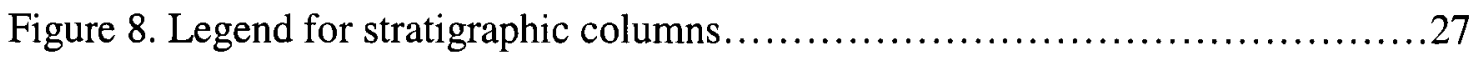

Figure 9. Deadhorse Meadows section showing sample locations, erosional surfaces (Roca, 2007), facies and foraminiferal zones. Refer to legend in figure 8. Allomembers above the FSU erosional surface have not been assigned and are therefore not labeled..................................................... 31

Figure 10. Deadhorse Meadows section: a. basal allomember WA lying unconformably over the Boulder Creek Formation. B. dark grey mudstone with interbedded fine grained sandstone of allomember WB

Figure 11. Deadhorse Meadows section: a. coarsening upwards sequence with a medium grained sandstone at the top of allomember WB b. $2 \mathrm{~cm}$ coal at WE1 surface indicated by the white arrow

Figure 12. Deadhorse Meadows section: a. Pyritized wood fragment in allomember FB.

B. unconformable contact of Cruiser Formation with overlying Dunvegan Formation .34

Figure 13. Range and abundance chart of foraminiferal species for Deadhorse Meadows outcrop 36 
Figure 14. Stratigraphic section of Nickerson Creek with location of foraminiferal samples, allostratigraphic surfaces (Roca, 2007), facies and foraminiferal zones

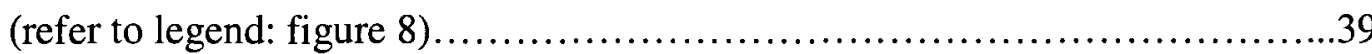

Figure 15 Outcrop photo of the Nickerson Creek locality showing the unconformable contact between the Viking allomembers (VB, VC and VD) and the overlying allomembers above the VE4 surface. .40

Figure 16. Range and abundance chart of foraminiferal species for Nickerson Creek and Sulphur River outcrops .42

Figure 17. Stratigraphic section of the Sulphur River section with location of foraminiferal samples, allostratigraphic surfaces (Roca, 2007), facies and foraminiferal zones. Refer to legend: figure 8

Figure 18. Outcrop photograph at the Sulphur River section showing allomembers VD, WA, WB, WC and FB (from Roca, 2007).

Figure 19. Stratigraphic section of the Mount Belcourt outcrop with location of foraminiferal samples, allostratigraphic surfaces, facies and foraminiferal zones (refer to legend: figure 8) .46

Figure 20. Outcrop photos of Mt. Belcourt: a. Spectacular outcrop exposure of allomembers VE, WA and WB lying between the Boulder Creek and Goodrich formations. B. Conglomerate unconformity with $8 \mathrm{~cm}$ of relief between Boulder Creek Formation and the VD allomember at the base of the Mt. Belcourt outcrop. 
Figure 21. Outcrop photos of Mt. Belcourt: a. Parallel lamination in dark grey mudstone seen in a streambed in allomember WA. B. Laterally continuous very fine sandstone beds with coarsening upwards cycles in the WB allomember.... .48

Figure 22. Outcrop photos of Mt. Belcourt: a. impression of an Inoceramus shell in the lower VD allomember. B. Unconformity between the WB allomember and Goodrich Formation 50

Figure 23. Range and abundance chart of foraminiferal species for Mount Belcourt.....52

Figure 24. Stratigraphic section of the Hasler Creek outcrop with location of foraminiferal samples, allostratigraphic surfaces, facies and foraminiferal zones (refer to legend: figure 8) .54

Figure 25. Outcrop photos of Hasler Creek: a. Outcrop exposure of allomembers WB and WC. B. Wave ripples in fine grained sandstone in allomember WB............55

Figure 26. Range and abundance chart of foraminiferal species for Hasler Creek

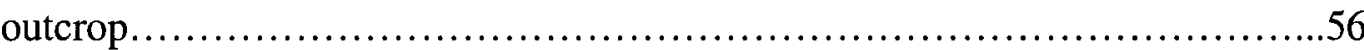

Figure 27. Stratigraphic section of the Moberly Lake Road outcrop with location of foraminiferal samples, allostratigraphic surfaces, facies and foraminiferal zones. Letters refer to different outcrops (refer to legend: figure 8 )................58

Figure 28. Outcrop photos of the Moberly Lake Road section: a. northernmost outcrop (a in figure 27) representing allomember VD. B. Second outcrop (b in figure 27) containing allomembers WA and WB .59

Figure 29. Outcrop photos of the Moberly Lake Road section: a. Outcrop c in figure 27; fine sandstone interbedded with mudstone coarsening upwards to medium grained 
sandstone containing allomembers WB and WC. b. Dark fine grained interval at $295 \mathrm{~m}$ (e in figure 27) in allomember WC..............................61

Figure 30. Outcrop photos of Moberly Lake Road section: a. Outcrop f in figure 27 showing very fine to fine grained 5 to $25 \mathrm{~cm}$ thick sandstones with mudstone interbeds in allomember FA. B. Hummocky cross-stratification in fine grained sandstone in allomember FA in outcrop $\mathrm{f}$ of figure 27

Figure 31. Outcrop photos of Moberly Lake Road section. a. Asymmetrical wave ripples in outcrop f (figure 27) in allomember FA. b. Allomembers FA and FB in outcrop $\mathrm{g}$ (figure 27) and Fish Scales marker bed (FSMB major flooding surface in Roca, 2007) .63

Figure 32. Section of outcrop along Moberly Lake Road containing a highly radioactive pebble bed that is tentatively correlated with the Fish Scale Marker Bed or FSMB in Roca (2007). 64

Figure 33. Range and abundance chart of foraminiferal species for Moberly Lake Road outcrop .66

Figure 34. Stratigraphic section of the Halfway River outcrop with location of foraminiferal samples, allostratigraphic surfaces, facies and foraminiferal zones (refer to legend: figure 8) .68

Figure 35. Outcrop of the Halfway River section containing allomembers VD and WA, containing mudstone with interbedded very fine to fine grained sandstone .69

Figure 36. Range and abundance chart of foraminiferal species for Halfway River......70 Figure 37. Stratigraphic section of the 10-33-34-5W5 core with location of foraminiferal samples, allostratigraphic surfaces and facies (refer to legend: figure 8)........72 
Figure 38 Range and abundance of foraminiferal species in cores 13-11-41-26W4, 10 -

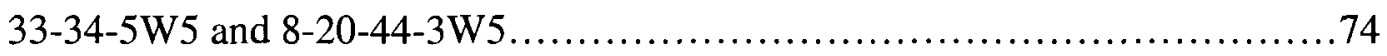

Figure 39. Stratigraphic section of the 13-11-41-26W4 core with location of foraminiferal samples, allostratigraphic surfaces and facies (refer to legend: figure 8).........75

Figure 40. Stratigraphic section of the 8-20-44-3W5 core with location of foraminiferal samples, allostratigraphic surfaces and facies (refer to legend: figure 8)........77

Figure 41. Allostratigraphic surfaces in the Deadhorse Meadows outcrop and well 11-362-12W6 (left curve is gamma ray log and right curve is resistivity) showing correlations of surfaces from outcrop into the subsurface (after Roca, 2007)......79

Figure 42. Black dots are wells used to create the NW-SE (blue line) and the east-west (green line) cross-sections. Red dots are outcrops from the study; 1: Halfway River 2: Moberly Lake Road 3: Hasler Creek 4: Mount Belcourt 5: Deadhorse Meadows

Figure 43. Cross-section SE-NW (blue line from figure 42) connecting established allostratigraphic framework of Roca (2007) with northeast British Columbia. Red curves represent gamma logs and black curves represent resistivity

Figure 44. . Cross-section E-W (green line from figure 42) connecting established allostratigraphic framework of Zhang (2006) with northeast British Columbia. Red curves represent gamma logs and black curves represent resistivity. .83

Figure 45. Left diagram shows the current foraminiferal zonation (Caldwell et al. 1993) alond with the outcrops used to create the subzonation in northeast British Columbia. The right diagram shows foraminiferal zones correlated to allomembers from this study along with selected outcrops from this study .86 
Figure 46. Schematic NW/SE cross-section from northwestern British Columbia to western Alberta showing the sequence of allomembers bounded by erosional surfaces and the distribution of foraminiferal zones. Modified from Roca 2007. See figure 4 for position of cross-section .87

Figure 47. Biostratigraphic range of some key species in the Albian and Cenomanian strata of western Canada and allostratigraphic members. Ranges after Caldwell et al. (1978, 1993) and this study. Allomembers after Roca (2007) .91

Figure 48a. Foraminiferal morphotypes shown as a percentage of entire sample with erosional surfaces labeled on the left and allomembers labeled on the right......105

Figure 48b. Foraminiferal morphotypes shown as a percentage of entire sample with erosional surfaces labeled on the left and allomembers labeled on the right......106

Figure 48c. Foraminiferal morphotypes shown as a percentage of entire sample with erosional surfaces labeled on the left and allomembers labeled on the right.....107

Figure 49. Relative abundances of morphotypes in neritic environments modified from Jones and Charnock (1985) 108

Figure 50. Relative abundances of morphotypes in allomembers and environments modified from Jones and Charnock (1985)

Figure 51. Summary of major geochemical, tectonic and sea level events associated with mid-Cretaceous oceanic anoxic events (OAEs) (from Leckie et al., 2002). Peace River foothills strata (Stott, 1982) showing the Fish Scale Marker Bed (FSMB) in comparison to global sea-level.

Figure 52. Possible correlation between the Deadhorse Meadows section and the 11-3622-1W2 well in eastern Saskatchewan (from Schröder-Adams et al. 1996) using 
erosional surfaces and total number of aggultinated foraminifera. Allomembers are labled in black

\section{LIST OF TABLES}

Table 1. Sections used in study and locations. 4

Table 2. Six facies (I to VI) are defined by their features of texture, stratification and ichnofossil content. The right column is the inferred depositional environment.

Table 3. summary of important relationships between fauna and sequences observed by; Rey et al., 1993; Scarponi and Kowalewski, 2007 and this study. LST: lowstand systems tract; TST: transgressive systems tract; HST: highstand systems tract; FSST: falling stage systems tract.

Table 4. Foraminiferal species richness (variable number of species results from multiple outcrops) and dominant genera for allomembers and depositional sequences.

Table 5. Paleoenvironment, life position, and feeding strategy of foraminera genera based on morphotypes. Modified from Chamney (1976) and Jones and Charnock (1985) 


\section{INTRODUCTION}

The sea-level history in the Western Canada Sedimentary Basin (WCSB) is associated with distinct macro- and micro- faunal assemblages. Paleontology has played an important role in paleogeographic and paleoecologic reconstructions of the WCSB. Macrofaunas such as molluscs are used as markers in regional correlation and have delivered a detailed zonation correlated with an absolute time scale (Warren and Stelck, 1969; Jeletzky, 1970, 1971a and 1971b). Macrofossils can be rare in Cretaceous marine rocks, in particular when work is based on core studies. In contrast, microfossils can be retrieved abundantly from core samples and have become a valuable correlation tool. The most detailed foraminiferal zonation for the WCSB originates in the foothills of British Columbia where expanded Rocky Mountain foredeep sections are associated with frequent faunal changes. The application of this detailed zonation with numerous subzones, however, has been problematic especially in condensed forebulge settings.

Recently a new allostratigraphic framework for Albian-Cenomanian strata has been proposed for western Alberta by Zhang (2006) and Roca (2007) who integrate these expanded foredeep outcrop sections with the subsurface of Alberta. The regional detailed correlation of strata that are bound by erosional surfaces requires a fresh look at the current biostratigraphic zones, which are limited to lithostratigraphic units. This study uses a multidisciplinary approach to address foraminiferal assemblages of the Rocky Mountain foredeep, integrating it with the new allostratigraphic framework and revisiting the region in northeast British Columbia where the original detailed zonation was created. Seven outcrops and three cores were studied in northeastern British Columbia and northwestern Alberta (Figure 1) in order to correlate foraminiferal assemblage changes 


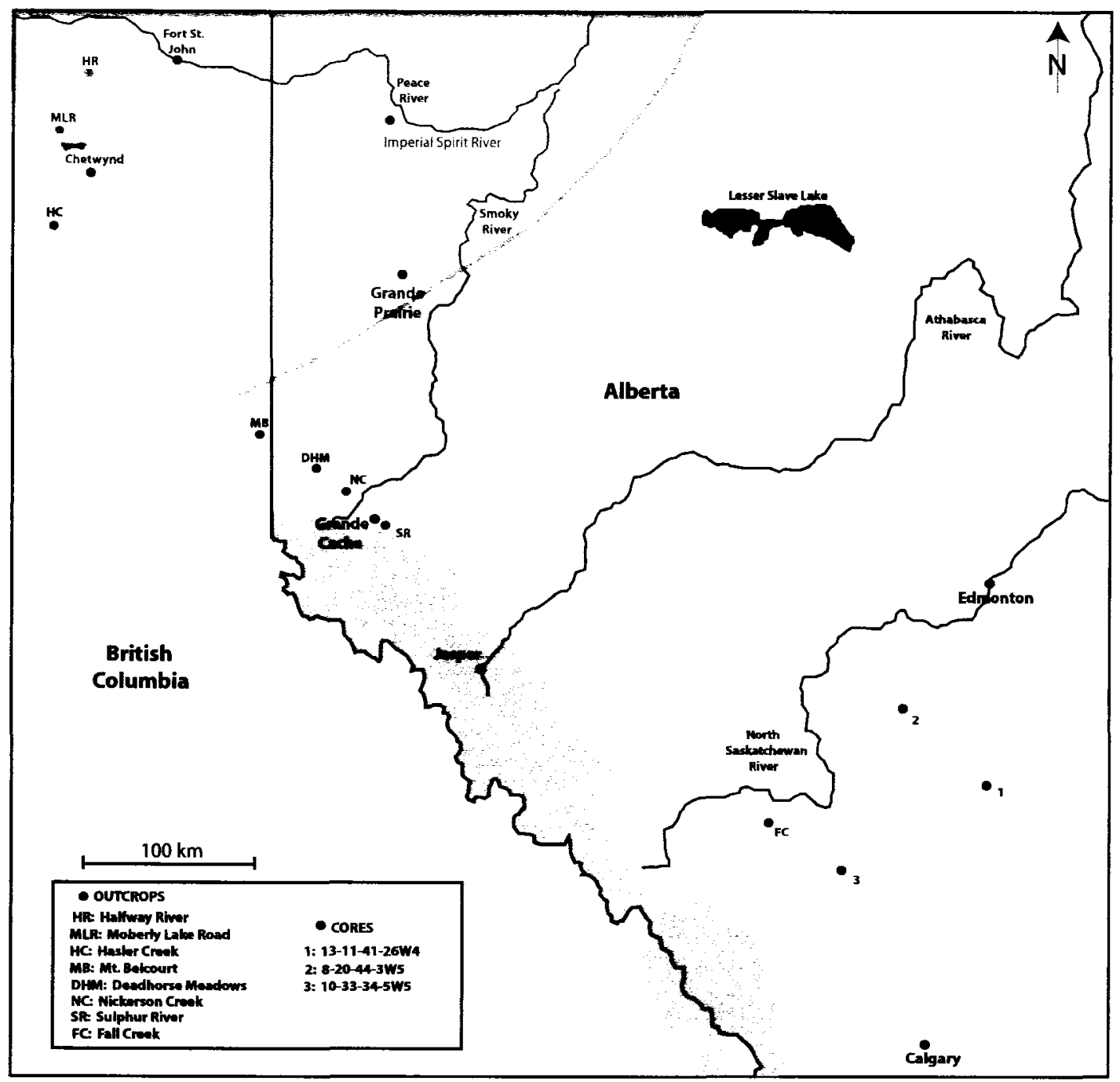

Figure 1. Location map of study area showing localities of sampled outcrops and wells with the Imperial Spirit River Well (Stritch et al. 1999) for reference. Green shaded areas are national parks and the grey shaded area represents the Peace River Arch structure. 
with allostratigraphic surfaces and resolve application problems of the current zonation as proposed by Caldwell et al. $(1978,1993)$.

Foraminifera provide critical information for testing paleoceanographic and sequence stratigraphic models. This includes faunal relationships to e.g. paleosalinity, paleoproductivitiy, stratification of ancient water masses, and oxygenation (Eicher, 1975; Eicher and Diner, 1985; Leckie et al., 1991; Caldwell et al., 1993). A number of patterns of paleoecology and even evolutionary changes appear to correlate with fluctuations in water depth and sedimentation through the course of a depositional sequence (Brett, 1998). Until recently, there has been little attempt to meld foraminiferal paleoecology with sequence stratigraphy (allostratigraphy) and it has never been proposed for Western Canada. This study attempts to interpret the paleoenvironment of Albian-Cenomanian strata within an allostratigraphic model.

\section{MATERIALS AND METHODS}

This study is based on 236 micropaleontological samples from seven outcrops and three cores in northeastern British Columbia and northwestern Alberta. The study area includes outcrops from Moberly Lake Rd., Halfway River, Hasler Creek, Deadhorse Meadows, Mt. Belcourt, Nickerson Creek, and Sulphur River (figure 1 and table 1). Cores at 13-11-41-26W4, 10-33-34-5W5 and 8-20-44-3W5 were also studied (figure 1). These cores are kept at the Alberta Core Board in Alberta Canada.

\section{Micropaleontology}

The biostratigraphic framework was established on vertical and lateral distribution of foraminiferal assemblages. Foraminiferal analysis was based on outcrop and core 


\begin{tabular}{|c|c|}
\hline SECTION & COORDINATES \\
\hline Deadhorse Meadows & $54 \operatorname{deg} 08^{\prime} 53^{\prime \prime} \mathrm{N}$ and $119 \operatorname{deg} 53^{\prime} 24^{\prime \prime} \mathrm{W}$ \\
\hline Sulphur River & $53 \operatorname{deg} 72^{\prime} 14$ ' $\mathrm{N}$ and $119 \operatorname{deg} 03^{\prime} 33^{\prime \prime} \mathrm{W}$ \\
\hline Nickerson Creek & $54 \operatorname{deg} 01^{\prime} 42^{\prime \prime} \mathrm{N}$ and $119 \operatorname{deg} 28^{\prime} 06^{\prime \prime} \mathrm{W}$ \\
\hline Mount Belcourt & $54 \operatorname{deg} 25^{\prime} 49^{\prime \prime} \mathrm{N}$ and $120 \operatorname{deg} 27^{\prime} 36^{\prime \prime} \mathrm{W}$ \\
\hline Hasler Creek & $55 \operatorname{deg} 33^{\prime} 40^{\prime \prime} \mathrm{N}$ and $121 \mathrm{deg} 58^{\prime} 50^{\prime \prime} \mathrm{W}$ \\
\hline Moberly Lake Rd & $\begin{array}{c}55 \operatorname{deg} 54^{\prime} 30^{\prime \prime}-55 \operatorname{deg} 55^{\prime} 30^{\prime \prime} \mathrm{N} \text { and } 121 \\
\operatorname{deg} 55^{\prime} 00^{\prime \prime} \mathrm{W}\end{array}$ \\
\hline Halfway River & $56 \operatorname{deg} 13^{\prime} 45^{\prime \prime} \mathrm{N}$ and $121 \operatorname{deg} 29^{\prime} 00^{\prime \prime} \mathrm{W}$ \\
\hline
\end{tabular}

Table 1. Sections used in the study and locations. 
samples, taken at variable intervals, depending on lithological boundaries, unusual characteristics of sediments, or other critical intervals. Samples for foraminiferal analysis were broken down according to the method described by Then and Dougherty (1983). Foraminifera were picked from the sand-size fraction $(>63 \mu \mathrm{m})$. Volumes of picked residues varied with foraminiferal abundance and the amount of material available; low abundance prohibited statistical analysis. Numerous samples were barren of foraminifera or had poorly preserved specimens. Total numbers of foraminifera are listed in the Appendix. Species were arranged in order of first appearance, followed by alphabetical order. Preservation of foraminifera was generally moderate to poor due to taphonomic processes such as crushing and fragmentation allowing in many cases genus identification only. Identification was based solely on original descriptions. Identified species were prepared and photographed under a binocular light microscope using a Sony Cyber-shot digital camera. Foraminiferal taxa were grouped into morphotypes according to Jones and Charnock (1985) for paleoenvironmental analysis.

\section{Sedimentology}

Sedimentological analysis is based on lithological description of cores and outcrops, which includes visual characteristics of sediments in terms of composition, grain size, sedimentary structure, trace fossils and fossil content. The allostratigraphic framework and core lithological descriptions were provided by Roca (2007).

\section{Wireline well log correlations}

Gamma ray and resistivity logs were used to establish correlations between cores in the British Columbia portion of the study to the Alberta portion where correlations 
have been provided by Zhang (2006) and Roca (2007). Their established allostratigraphic framework and erosional surfaces were utilized in extending allostratigraphy into British Columbia. Well control covering the study interval in this region is much reduced due to thrusting and subsequent erosion. The regional wireline log cross-section in the British Columbia study area was constructed using Crosslog, the online digital database from Divestco Inc.

\section{GEOLOGIC SETTING}

\section{Basin architecture}

In the Early to Middle Jurassic the break-up of Pangea caused the northwestward movement of the North American Plate over the Farallon Plate creating an east-dipping subduction zone. This large scale, tectonically driven evolution was caused by loading of the continental lithosphere by plutonism, volcanism, accretion and lateral displacement of pericratonic and accreted terrains (Monger and Nokleberg, 1995). The static and dynamic loads caused subsidence on a large area of the craton and the formation of a foreland basin, which, combined with an eustatic sea-level highstand, culminated in the Cretaceous Western Interior Sea.

The Western Interior Sea developed between the Cordillera and the stable interior craton. At its maximum extent it was more than $6000 \mathrm{~km}$ long, stretching from the Arctic Ocean (Boreal Sea) to the Gulf of Mexico (Tethyan Sea) and up to $1600 \mathrm{~km}$ wide, extending from westernmost Ontario to central British Columbia (Leckie and Smith, 1992). Over the evolution of the basin, from the Middle Jurassic to the Middle Tertiary, 
over six km of sediment was deposited along the western margin of the basin (Leckie and Smith, 1992). The sediment package tapers eastward in the WCSB, forming a wedge which covers the Precambrian crystalline basement of the North American craton (Price, 1994).

Tectonic events in the Cordillera largely controlled the supply of sediment to the foreland basin and significantly influenced accommodation space. During the latest Jurassic the first pulse of the Columbian Orogeny began with tectonic activity on the western margin of the basin (Stott, 1984). This resulted in an increased rate of sediment deposition in the expanding foreland basin that lasted until the end of the early Tertiary (Leckie et al., 1989). The development of a foredeep on the western edge of the basin allowed for the formation of a thick clastic wedge, composed primarily of sandstones, siltstones and shales. This thickened wedge records the most complete record of transgression and regression within the basin. As subsidence in the foredeep kept pace with sedimentation of marine and alluvial sediment, the development of an associated forebulge formed further east where condensed sections developed due to reduced sediment supply and subsidence (Kauffman and Caldwell, 1993). These hiatuses are often recognized by missing biostratigraphic zones (Caldwell et al., 1993; SchröderAdams et al., 1996).

\section{Relative sea-level history}

Although regional and local tectonics largely controlled the source and rate of sedimentation within the WCSB, some accommodation space was supplied through eustatic sea-level changes (Jervey, 1992). Cretaceous strata within the WCSB were deposited in a series of nine major transgressive-regressive marine cycles (Kauffman 
1977, 1984: Kauffman and Caldwell 1993). During the Albian (figure 2), the basin was influenced by two eustatic cycles, the Kiowa-Skull Creek and the basal transgressive phase of the Greenhorn Cycles (Kauffman, 1977). In the WCSB the global eustatic cycles were locally overprinted in the Albian by the Moosebar, Hulcross, Joli Fou and Mowry transgressions (Caldwell, 1984; Leckie and Smith, 1992). During times of maximum transgression (Joli Fou, Greenhorn and Niobrara), the northern and southern portions of the Western Interior Seaway were connected, allowing the northern Boreal waters to mix with southern Tethyan waters (Stelck, 1975). Deposition of the various strata within the Albian and Cenomanian was during a period of overall global eustatic sea-level rise, punctuated by several relative sea-level falls (Kauffman, 1977).

Early late Albian sea-level rise resulted in a narrow seaway connecting the Tethyan and Boreal seas, depositing the Joli Fou Formation. The succeeding lowstand terminated the Tethyan connection and deposited the Viking Formation which consists of marine sandstone and conglomerate throughout much of western to central Alberta. Along the western margin incised valleys were cut and subsequently infilled with estuarine sediments during sea-level rise (Leckie and Smith, 1992).

The subsequent transgression is associated with the Mowry Sea bringing cool, low salinity, Boreal watermasses and depositing the Westgate Formation (Bloch et al., 1993; Schröder-Adams et al., 1996). This transgression represents the beginning of the global eustatic Greenhorn cycle but is interrupted by several relative sea-level falls. 


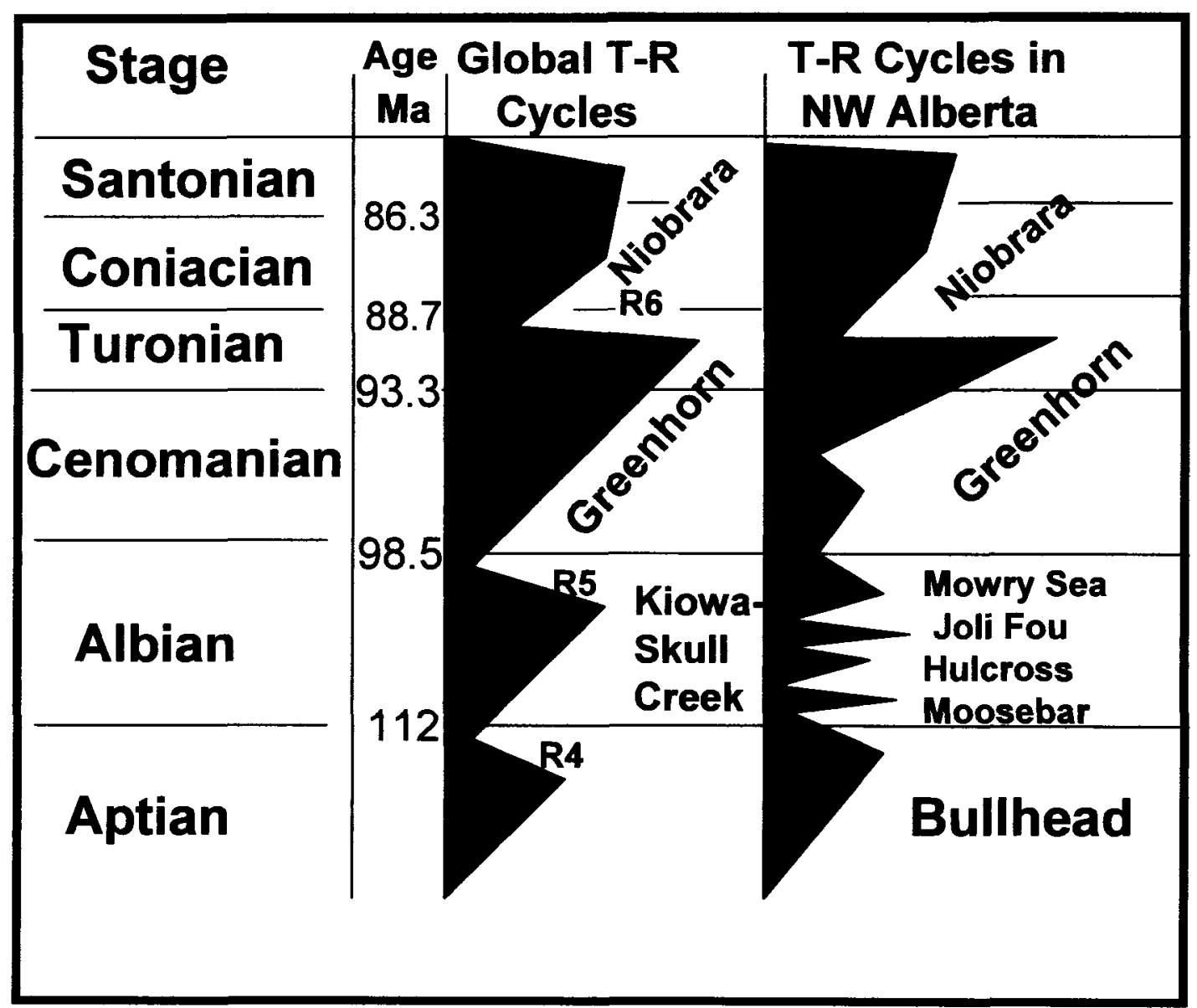

Figure 2. Global transgressive-regressive cycles and transgressive-regressive cycles in northwest Alberta of the WCSB during the Cretaceous (Aptian to Santonian) and radiometric ages at stage boundaries. Modified after Kauffman (1977) and Obradovich (1993). 


\section{Structure}

Located in northeastern British Columbia and northwestern Alberta, the Peace River Arch is a significant northeast-trending Precambrain basement feature (Leckie et al., 1990) (figure 1), that has undergone several periods of uplift and subsidence during Phanerozoic time (Chen and Bergman, 1999). The block-faulted Peace River Arch was uplifted during the early Cambrian and remained a structural high until the Late Devonian (Cant, 1988; O'Connell et al., 1990). During the Mississippian, the arch began to subside and remained a topographic low until the Early Cretaceous (Cant, 1988; Leckie et al., 1990). During the latest Cretaceous and Tertiary, the arch again became a positive feature as a result of Laramide deformation farther west (Williams, 1958, Cant, 1988).

\section{Lithostratigraphy}

The Peace River area was first explored by Sir Alexander Mackenzie as early as 1792 (Stott, 1968). More detailed reports appeared in 1881 by George M. Dawson who named strata overlying the present day Notikewin Member the Fort St. John Shales (Stott, 1968). This was followed by Wickenden and Shaw (1943) who distinguished subdivisions such as Moosebar, Commotion, Hasler, Goodrich and Cruiser formations, creating the Fort St. John Group. As more subsurface data became available for correlation, Stott (1982) suggested removal of the name Commotion Formation and gave the Gates, Hulcross and Boulder Creek (members of the Commotion Formation) formation status. An extensive lithostratigraphic framework correlating outcrops of the Rocky Mountains with the subsurface of Alberta was proposed by Stott (1982). No major modifications have occurred since. Figure 3 illustrates the current stratigraphic nomenclature for the northeastern British Columbia Foothills, northwestern Alberta Peace 


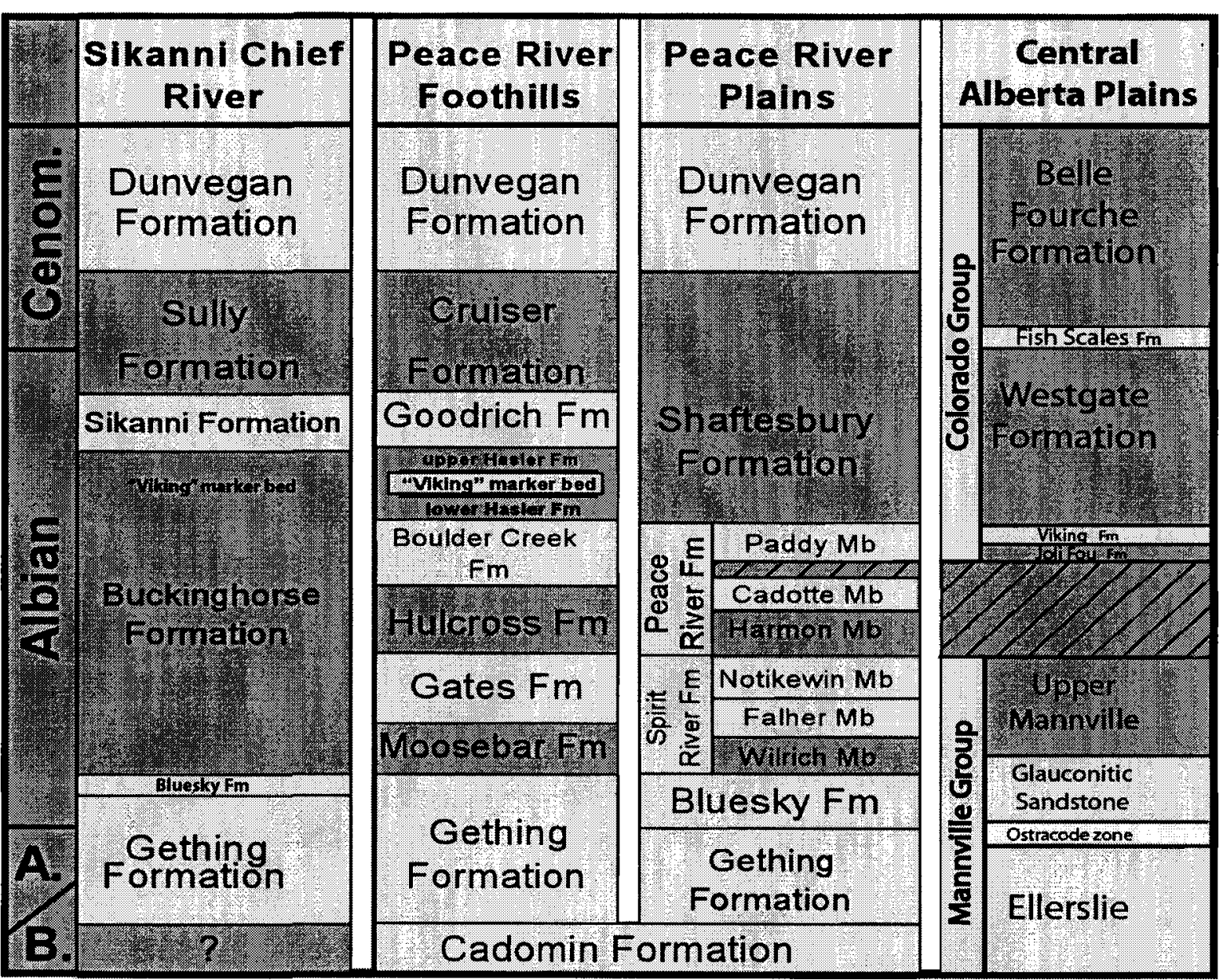

Figure 3. Regional stratigraphic nomenclature for the study area in northeast British Columbia and northwest Alberta. Modified from Stott (1982), Stelck and Koke (1987), Bloch et al. (1993) and Schröder-Adams and Pedersen (2003) 
River Plains, central Alberta Plains and the Sikanni Chief River region to the north of the study area.

Lithostratigraphy is based on physical characteristics that are recognizable on a regional scale. However, basin-forming processes result in a laterally variable sediment package. As a result stratigraphic nomenclature differs from the northeastern British Columbia Foothills to northwestern Alberta Peace River Plains and to central Alberta Plains (figure 3). In the subsurface of the Peace River Plains, the Fort St. John Group (Albian to lower Cenomanian) consists of the Spirit River, Peace River and the Shaftesbury formations in ascending stratigraphic order (figure 3). The Spirit River Formation has been further subdivided into the Wilrich, Falher and Notikewin members, while the Harmon, Cadotte and Paddy members form the Peace River Formation. Farther to the east in the Central Alberta Plains the Albian to Cenomanian strata consists of the Mannville Group and the Lower Colorado Group. The Lower Colorado Group is then further divided into the Joli Fou, Viking, Westgate, Fish Scales and Belle Fourche formations.

In the foothills of northeastern British Columbia, the study area comprises the upper Albian to Cenomanian strata of the Hasler, Goodrich and Cruiser formations (figure 3). All three formations are equivalent to the Shaftesbury Formation of the Alberta Peace River Plains (Stelck and Leckie, 1990). The Shaftesbury Formation is in turn equivalent to the Westgate, Fish Scales and lower Belle Fourche formations of the Colorado Group (figure 2) (Warren and Stelck, 1969; Stelck and Leckie, 1990; Bloch et al., 1993). 


\begin{abstract}
Allostratigraphy
An allostratigraphic unit is a mappable stratiform body of sedimentary rock that is defined and identified on the basis of its bounding discontinuities (NACSN, 1983, p. 865). Bounding discontinuities highlight important changes in depositional conditions. Thus they define allostratigraphic units in which depositional conditions were either fairly constant, or were progressively changing but without breaks (as in a sandier-upward succession). For this reason, allostratigraphic units are more natural subdivisions of the geological record for interpretive purposes than conventional lithostratigraphic units. A allostratigraphic framework of the Viking Formation in Alberta was originally proposed by Boreen and Walker (1991), who used well logs and cores to map three erosional surfaces in the Viking Formation in south-central Alberta (Willesden Green area). These erosion surfaces (Viking erosion surfaces VE2, VE3 and VE4), or bounding discontinuities, allowed the definition of five allomembers in the Willesden Green study area (Boreen and Walker, 1991). Roca (2007) and Zhang (2006) have expanded this work using a combined 47 outcrops, 223 cores and 2630 well logs to extend the allostratigraphic framework over large portions of western Alberta (figure 4). They also extended the framework to include allomembers from the underlying Joli Fou Formation up to the overlying Fish Scales Marker Bed. Figure 5 shows the differences between allostratigraphic and lithostratigraphic units. Allostratigraphic surfaces can best be identified in wireline log cross-sections, which are then extended into near-by outcrop. Often, the projected position of some surfaces in measured sections coincides with only subtle lithological change. Micropaleontological data can play an important role in supporting or disputing the position of these surfaces.
\end{abstract}




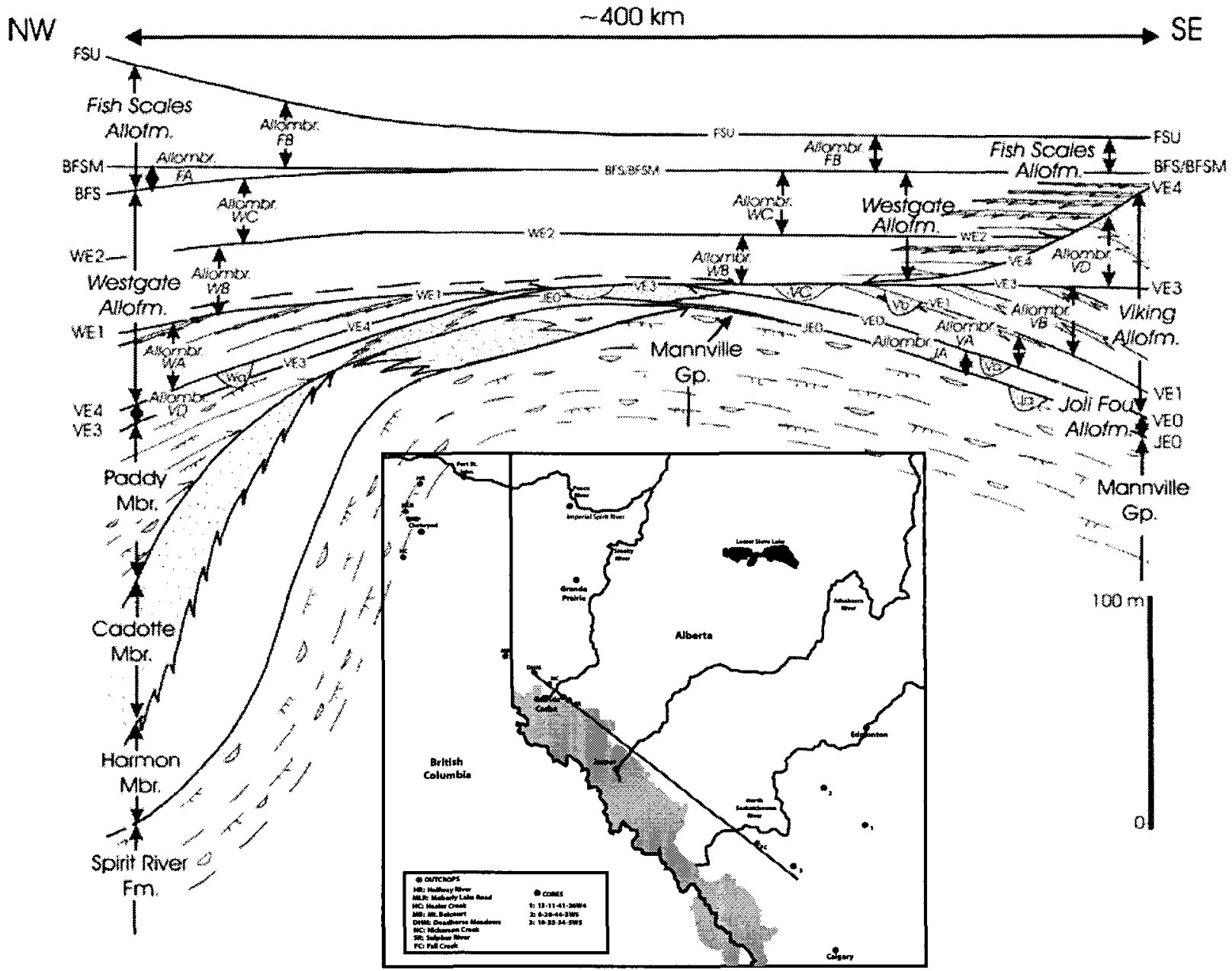

Figure 4. Allostratigraphic cross-section for western Alberta (Roca 2007). Erosional surfaces are labeled on the left and right margin of the cross-section and allomembers are labeled between erosional surfaces. Allomembers represent lithostratigraphic strata from the Viking and Westgate formations. 


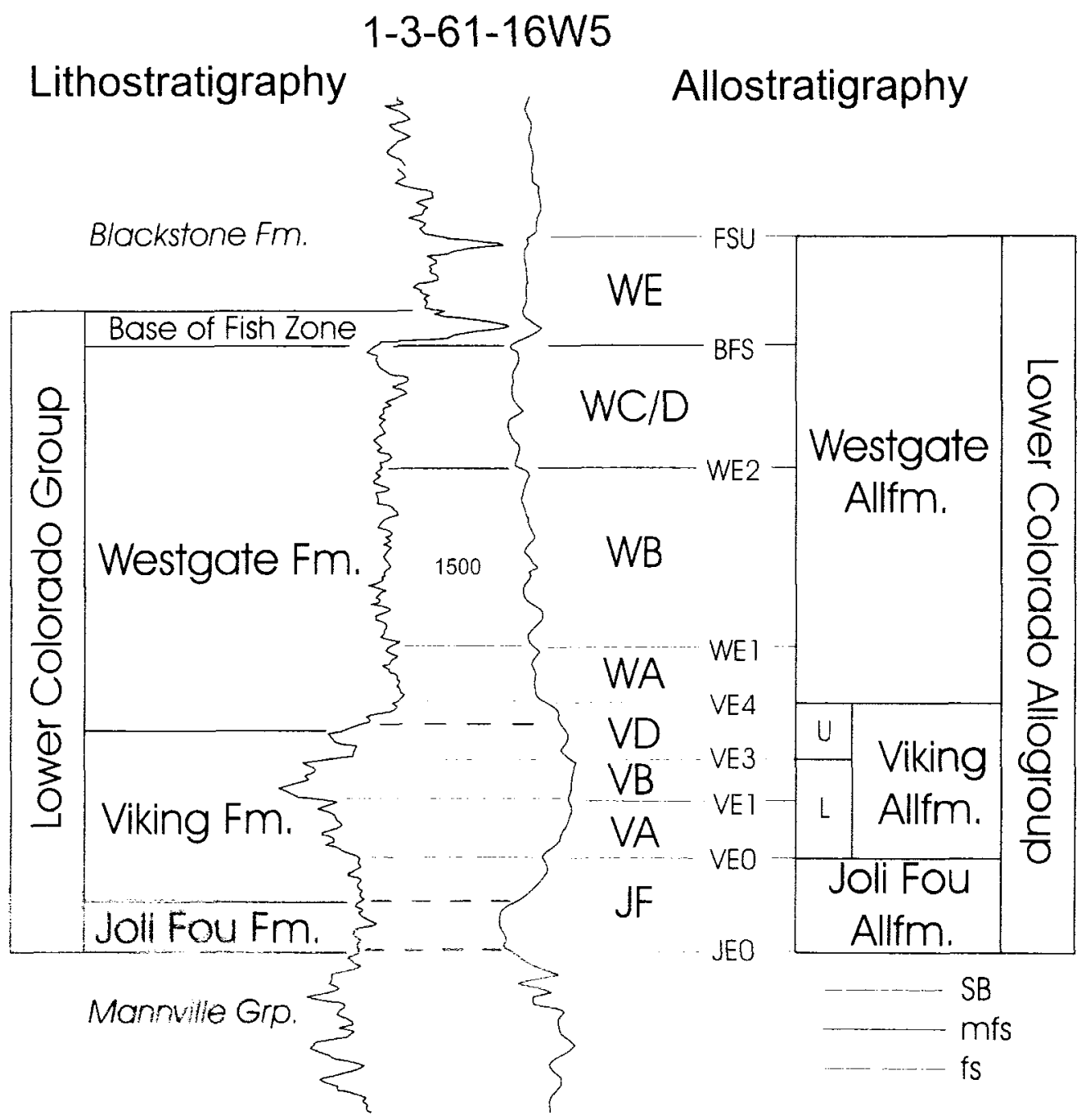

Figure 5. Differences in lithostratigraphy and allostratigraphy of the Lower Colorado Group (Roca, 2007). SB: sequence boundary, mfs: maximum flooding surface and fs: flooding surface. 
This study integrates foraminiferal data with the allostratigraphic framework. Some outcrops from this study (Deadhorse Meadows, Nickerson Creek, Sulphur River, and cores 13-11-41-26W4, 10-33-34-5W5 and 8-20-44-3W5) coincide with sections used by Roca (2007). These outcrops are used to facilitate detailed correlations between faunal changes and allomembers. Samples for foraminiferal data for this study have been gathered from sections that are stratigraphically higher than the Viking erosive surface 3 (VE3), therefore this study will only use allomembers and surfaces above the VE3 surface (figure 4). These are allomembers VD, WA, WB, WC, FA and FB and associated erosional surfaces VE3, VE4, WE1, WE2, BFS, BFSM and FSU. This study extends the allostratigraphic model outside of Alberta and into northeast British Columbia using the existing well $\log$ data as a reference and starting point.

\section{Foraminiferal Biostratigraphy}

The presence of foraminifera in Cretaceous rocks in the WCSB is well known and Caldwell et al., (1978) proposed a comprehensive foraminiferal zonation for the WCSB. Numerous studies have been published describing Albian-Cenomanian age foraminifera throughout the American and Canadian portions of the Western Interior Basin. Excluding the endemic species that developed within the Western Interior Sea, the dominant agglutinated foraminiferal faunas of northeast British Columbia and northwest Alberta have more species in common with Cretaceous assemblages described from the Arctic slope of Alaska (Tappan, 1962) than with those of the Gulf Coast (Schröder-Adams et al., 1996; Stelck, 1991), suggesting a more continuous connection to the Boreal Sea.

The foraminiferal scheme has been correlated as much as possible to the molluscan zones outlined by Jeletzky $(1968,1970,1971 a, 1971 b)$ for the Western Interior 
of Canada (figure 6). In the Peace River and Sikanni Chief River areas, a number of foraminiferal studies have resulted in a detailed zonation for the Albian-Cenomanian of northeastern British Columbia (Wickenden, 1951; Stelck et al., 1956; Stelck, 1958; Sutherland and Stelck, 1972; Stelck 1975, 1991; Stelck et al., 2000; Stelck and Hedinger, 1983; Koke and Stelck, 1984, 1985; Stelck and Koke, 1987; Stelck and Leckie, 1990; Stritch and Schröder-Adams, 1999 and Schröder-Adams and Pedersen, 2003).

For Western Canada Caldwell et al. $(1978,1993)$ established three foraminiferal zones within the Albian Stage: the Gaudryina nanushukensis Zone, Haplophragmoides gigas Zone, and Miliammina manitobensis Zone (figure 6). Correlations with molluscan zones (Stelck and Koke, 1987; Caldwell et al., 1993) place the Gaudryina nanushukensis Zone within the early to middle Albian, the Haplophragmoides gigas Zone within the early late Albian, and the Miliammina manitobensis Zone within the late late Albian (figure 6). In northeastern British Columbia these three zones have their fullest expression and are subdivided into a number of subzones - six within the Gaudryina nanushukensis Zone (Caldwell et al. 1978), seven within the Haplophragmoides gigas Zone (Stelck and Koke, 1987; Stelck, 1991), and three within the Miliammina manitobensis Zone (Caldwell, 1978) (figure 6).

In the foredeep setting of the Peace River area, much of the refinement of the foraminiferal zonation has taken place within the Hasler, Goodrich and Cruiser formations. In the Peace River area, (northeastern British Columbia) in the lower part of the Hasler Formation, Koke and Stelck $(1984,1985)$ described the Ammobaculites wenonahae Subzone of the Gaudryina nanushukensis Zone in sections along the Halfway River just north of the Peace River. This subzone has also been recognized in the middle part of the Buckinghorse Formation by Schröder-Adams and Pedersen (2003) in the 


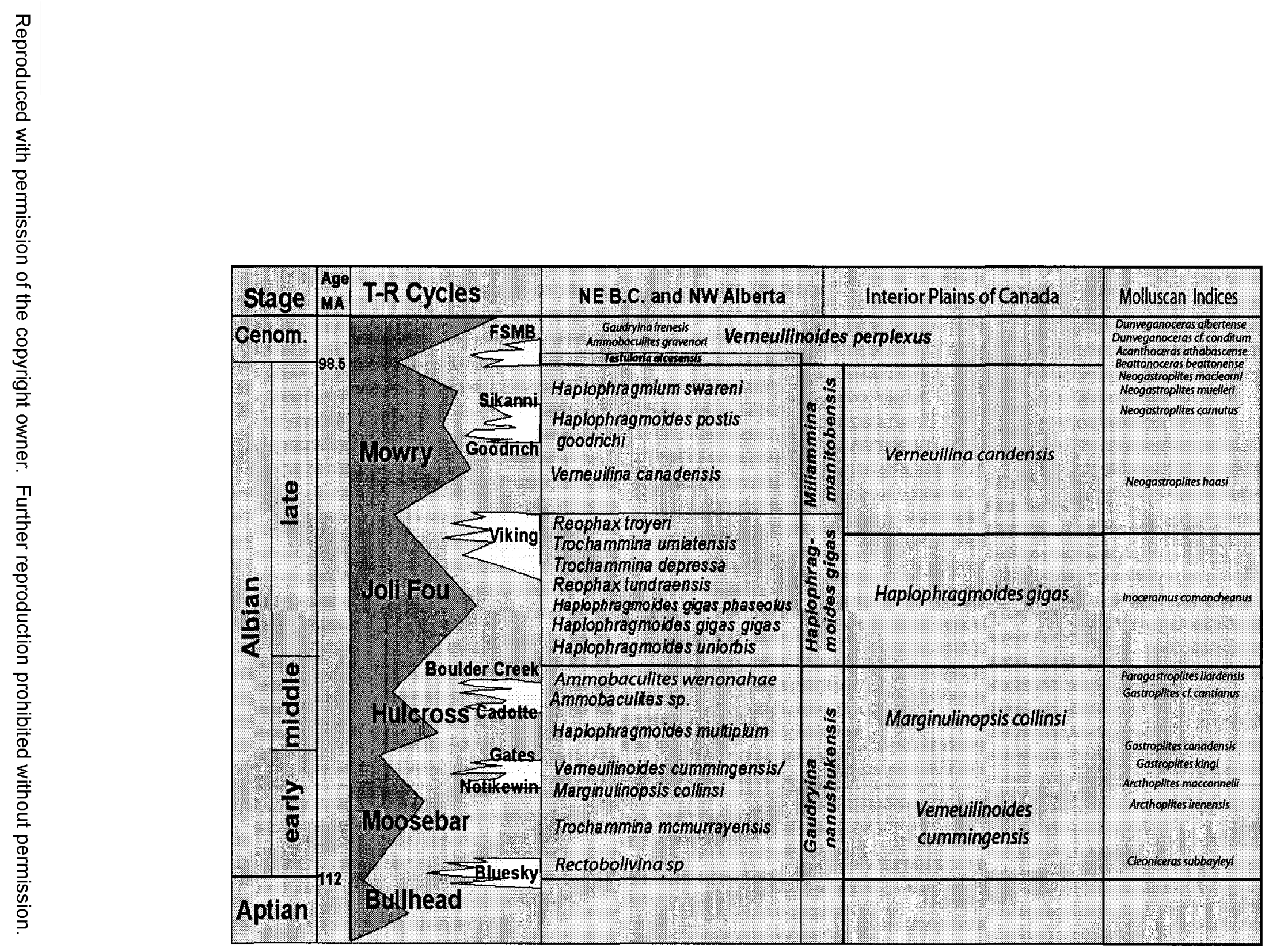

Figure 6. Foraminiferal zones and subzones of Aptian to lower Cenomanian stages, macrofossil zones and their relationship with sea-level changes (modified after Schröder-Adams and Pedersen 2003). 
Sikanni Chief River area. This subzone seems to have been retained only in the short segment of the foredeep of the basin northward from the Peace River to the southern end of the Mackenzie Mountains in the Northwest Territories (Caldwell et al. 1993).

Substantial refinement of the Haplophragmoides gigas Zone has resulted from analysis of Rocky Mountain foothills sections of northeastern British Columbia. In the Peace and Pine River valleys, the zone contains seven subzones (Stelck and Koke, 1987 and Stelck, 1991) whereas faunas farther east and south within the interior plains lack subzones (Caldwell et al., 1993). In the Canadian prairie region, the zone has been widely identified as the biostratigraphic counterpart of the Joli Fou Formation, and Koke and Stelck (1985) described the foraminifera of the Joli Fou equivalent in the lower Hasler Formation of the Peace River region. Stelck and Koke (1987) then showed that the zone should be extended through much of the upper Hasler Formation by describing a sequence of assemblages that are related to those of the Joli Fou equivalent.

In the outcrops studied the lowermost Haplophragmoides uniorbis Subzone is present in the Halfway River $3.5 \mathrm{~km}$ above the mouth of the Halfway River where the contact can be found with the underlying Ammobaculites wenonahae Subzone (Stelck, 1991). Stelck (1991) also found the uppermost $14 \mathrm{~m}$ of the H. uniorbis Subzone exposed in the Moberly Lake Road outcrop.

The Haplophragmoides gigas gigas Subzone has been recognized in two outcrops on the northern bank of the Peace River near the Halfway River and in the Moberly Lake Road outcrop. In the Moberly Lake Road outcrop the indicator species Haplophragmoides gigas gigas is absent and a smaller variety has been assigned to $H$. gigas (Stelck and Koke. 1987). The overlying Haplophragmoides phaseolus Subzone (originally name Haplophragmoides gigas ssp. A by Stelck and Koke, 1987; Stelck, 
1991) is also based on a variety of $\mathrm{H}$. gigas and has no clear cut boundary with the underlying $H$. gigas gigas Subzone (Stelck and Koke, 1987). Instead, Kechenotiske (a foraminiferal taxa) has been used as a marker for the top of the $\mathrm{H}$. gigas gigas Subzone and is purely arbitrary (Stelck and Koke, 1987). The Haplophragmoides phaseolus Subzone has been recognized in the Moberly Lake road cuts and on the Halfway River north of the Peace River by Stelck and Koke (1987). The upper contact of this subzone has not been observed in outcrop and has been assumed to be transitional, as many foraminifera are common to the overlying Reophax tundraensis Subzone (Stelck and Koke, 1987).

The Reophax tundraensis Subzone has been recognized in the Moberly Lake road cuts in what Stelck and Koke (1987) have designated the "Viking" marker bed. The $R$. tundraensis Subzone has not been recognized in the Pine River valley $50 \mathrm{~km}$ south of the Peace River (Caldwell et al., 1993). Stelck and Koke (1987) also note that neither the lower or upper contact of this subzone has been observed in outcrop.

On Dokie Ridge, which represents the type section for the Hasler Formation, and Commotion Creek basal beds of the Hasler contain the Trochammina depressa Subzone indicating that only the upper part of the formation is represented at its type section (Stelck and Koke, 1987). Stelck and Koke (1987) also note that this is where the species Haplophragmoides postis goodrichi, forming a subzonal indicator of the overlying Miliammina manitobensis Zone, first appears. The top of the Trochammina depressa subzone is recognized in the Moberly Lake road cuts above the Reophax tundraensis Subzone. The lower contact of this unit is exposed in the Commotion Creek outcrop where Stelck and Koke (1987) suggest a conformable contact with the underlying 
Boulder Creek Formation. The upper contact is exposed in the road cut on Moberly Lake Road where Stelck and Koke (1987) note no change in lithology.

On Dokie Ridge the Trochammina depressa Subzone is overlain by the Trochammina umiatensis Subzone with a total thickness of $90 \mathrm{~m}$ (Stelck and Koke, 1987). This subzone on Boulder Creek, Moberly Lake Road and Hasler Creek occurs below the "Viking grits", which is not to be confused with the "Viking" marker bed.

On Hasler Creek above the Trochammina depressa Subzone and below the grit beds is the Reophax troyeri Subzone (Stelck and Koke, 1987). This subzone is absent in the Dokie Ridge section, poorly represented in a ditch in the Moberly Lake road cuts and has its most complete expression in the Hasler Creek outcrop (Stelck and Koke, 1987).

Like the Haplophragmoides gigas Zone, the Miliammina manitobensis Zone has its fullest expression in the foredeep of the WCSB in northeastern British Columbia, where it carries three diverse successive faunas; Verneuilinoides canadensis, Haplophragmoides postis goodrichi and Haplophragmium swareni (Caldwell et al., 1993). The Miliammina manitobensis Zone has been described from the upper parts of the Hasler and Buckinghorse formations (Stelck, 1975; Schröder-Adams and Pedersen, 2003), lower Sully Formation (Stelck and Hedinger, 1983), and the base of the Shaftesbury Formation (Nielsen, 1950; Stritch and Schröder-Adams, 1999). While the Miliammina manitobensis Zone is the most widespread Albian foraminiferal zone in western Canada only the Verneuilina canadensis Subzone can be identified east and south of British Columbia (Caldwell et al., 1978). The overlying Haplophragmoides postis goodrichi and Haplophragmium swareni Subzones have only been recognized in the foothills of northeastern British Columbia (Stelck and Hedinger, 1976). 
In the Peace River area in northeastern British Columbia, where the Miliammina manitobensis Zone has its fullest expression, the zone is marked by an erosional base expressed as a thin pebble conglomerates. The pebble beds are the equivalent of the "Viking grits" (Stelck, 1975; Hein et al., 1986) in the Alberta plains and their base marks an unconformity that cuts across the Alberta foothills (Caldwell et al., 1993). This unconformity has removed the Reophax troyeri Subzone in the Moberly River area (Caldwell et al., 1993) and further south and east into Alberta the remainder of the Haplophragmoides gigas Zone has been removed to the extent that the Miliammina manitobensis Zone lies on older Albian beds (Caldwell et al., 1993).

The Verneuilinoides canadensis Subzone was originally described by Stelck (1975) on the Sikanni Chief River in northeastern British Columbia. The V. canadensis Subzone is extremely widespread, having been recognized throughout the Western Interior of Canada and in adjacent parts of the United States (Caldwell et al. 1978). According to Sutherland and Stelck (1972) in the Moberly Lake roadcut the Haplophragmoides postis goodrichi Subzone lies above the $V$. canadensis Subzone which is not exposed in the Moberly Lake roadcut. Sutherland and Stelck (1972) found the $H$. postis goodrichi Subzone in the Goodrich sands within the Moberly Lake road cuts. However, Stritch and Schröder-Adams (1999) found that the H. postis goodrichi Subzone lies below the $V$. canadensis Subzone in the Spirit River well in northwest Alberta south of Peace River town. The uppermost subzone in the Miliammina manitobensis Zone was first described by Stelck and Hedinger (1983) in the lower Sully Formation, directly underlying the Fish-Scale Marker. The Haplophragmium swareni Subzone has since been recognized in the Sikanni Formation in the Sikanni Chief River area of British 
Columbia (Schröder-Adams and Pederson, 2003) and in the Lower Sully Formation in the Liard Plateau (Jowett and Schröder-Adams, 2005).

The Textularia alcesensis Zone was first described by Stelck (1958) and straddles the Albian-Cenomanian boundary. It has been found in the Peace River plains and the Rocky Mountain foothills of northeastern British Columbia and northwestern Alberta, from the base of the Fish Scale Marker to the base of the Dunvegan Formation (Caldwell et al. 1978), and at Cadomin (Leckie et al., 2000). From central Alberta to the Manitoba Escarpment, the T. alcesensis Zone is absent and the end of the Albian is marked in these regions by a complete disappearance of benthic foraminifera in the lower Cenomanian Fish Scales Formation (McNeil and Caldwell, 1981; Bloch et al. 1993; Schröder-Adams et al., 1996).

The early Late Cenomanian Verneuilinoides perplexus Zone has been divided into the Ammobaculites gravenori and Gaudryina irenensis subzones (Caldwell et al., 1978). Both subzones were originally described in the Kaskapau Formation in the Peace River area by Stelck and Wall $(1954,1955)$ and can be found in northeastern British Columbia and northwestern Alberta. Farther east in the WCSB in more condensed strata only a single zone can be distinguished (Caldwell et al., 1978, 1993) containing elements that are common to both subzones.

\section{BIOSTRATIGRAPHIC CHALLENGES}

Benthic foraminifera are employed widely as tools to determine biostratigraphic framework and to reconstruct paleoenvironments. Since the Cambrian, they have diversified along with other groups of the Kingdom Protista (Escalante and Ayala, 1996) and have been present in a wide range of environments, from shallow brackish waters to 
the deepest parts of the ocean (Van der Zwaan et al., 1999). Their agglutinated or calcareous tests have allowed them good fossilization potential in a variety of diagenetic regimes, which in combination with their abundance makes them useful tools.

Planktonic foraminifera were rare in the Canadian Western Interior Sea, appearing only in the Late Cenomanian, Turonian and Santonian Stages, when Tethyan watermasses were widespread in the Western Interior Sea. In contrast, benthic foraminifera were relatively common, although their abundance was reduced by phases of bottom water anoxia. The Albian-Cenomanian strata in the WCSB contain an almost exclusive agglutinated benthic fauna, where as calcareous benthic fauna have been found only sporadically (Stelck and Koke, 1987; Harrison, 1988; Stelck et al., 2000). Using the almost exclusive agglutinated benthic foraminifera as biostratigraphic markers and paleoenvironmental indicators presents a number of challenges.

Taphonomy is the fundamental problem of preservation and modification of the fossil assemblage. In general, the most significant post-mortem processes affecting preservation are transport and various modes of destruction (Murray and Alve, 1999). Transport of foraminiferal tests can lead to the loss of fragile tests or the introduction of allochthonous tests. Early diagenesis can cause the dissolution of calcareous tests from increased carboxylic acid in the pore water or disintegration of agglutinated tests from iron reduction utilizing iron present in foraminiferal cement (Hesse, 1984). The introduction of meteoric water during diagenesis can also lead to the dissolution of calcareous components due to the corrosive, low salinity nature of the water being introduced (Veizer, 2003). Burial diagenesis can also alter the foraminiferal assemblage. The increased temperature and pressure of burial can cause silicification, color alteration and distortion of tests making taxonomic placement difficult (McNeil et al., 1996). 
An additional challenge working with agglutinated foraminifera is intraspecific variability hampering taxonomic placement of species. In order to create a useful biostratigraphic zonation key indicator foraminiferal species must be easily identifiable, widely distributed and have a short biostratigraphic range. Some authors have resorted to splitting resulting in short biostratigraphic ranges of species or subspecies. However, considering the high degree of taphonomic alteration to faunal elements within the WCSB great care must be taken that these variations represent truly different species and not just intraspecific variations, e.g. as response to substrate changes.

Figure 7 demonstrates possible intraspecific variability within the genus Haplophragmoides. Species 1-3 in the figure are easily recognizable and clearly defined species of Haplophragmoides. However, species 4-10 are believed to be representative specimens of Haplophragmoides postis (from a single sample) as defined by Stelck and Wall (1955). Subsequently some authors have subdivided the $H$. postis into a number of subspecies. It remains, however, unclear if each type represents a true evolutionary change or is a response to variations that are environmentally dependent. In modern agglutinated assemblages, intraspecific variability has frequently been observed as a response to substrate changes providing variable grains for test construction (Schröder, 1986). 


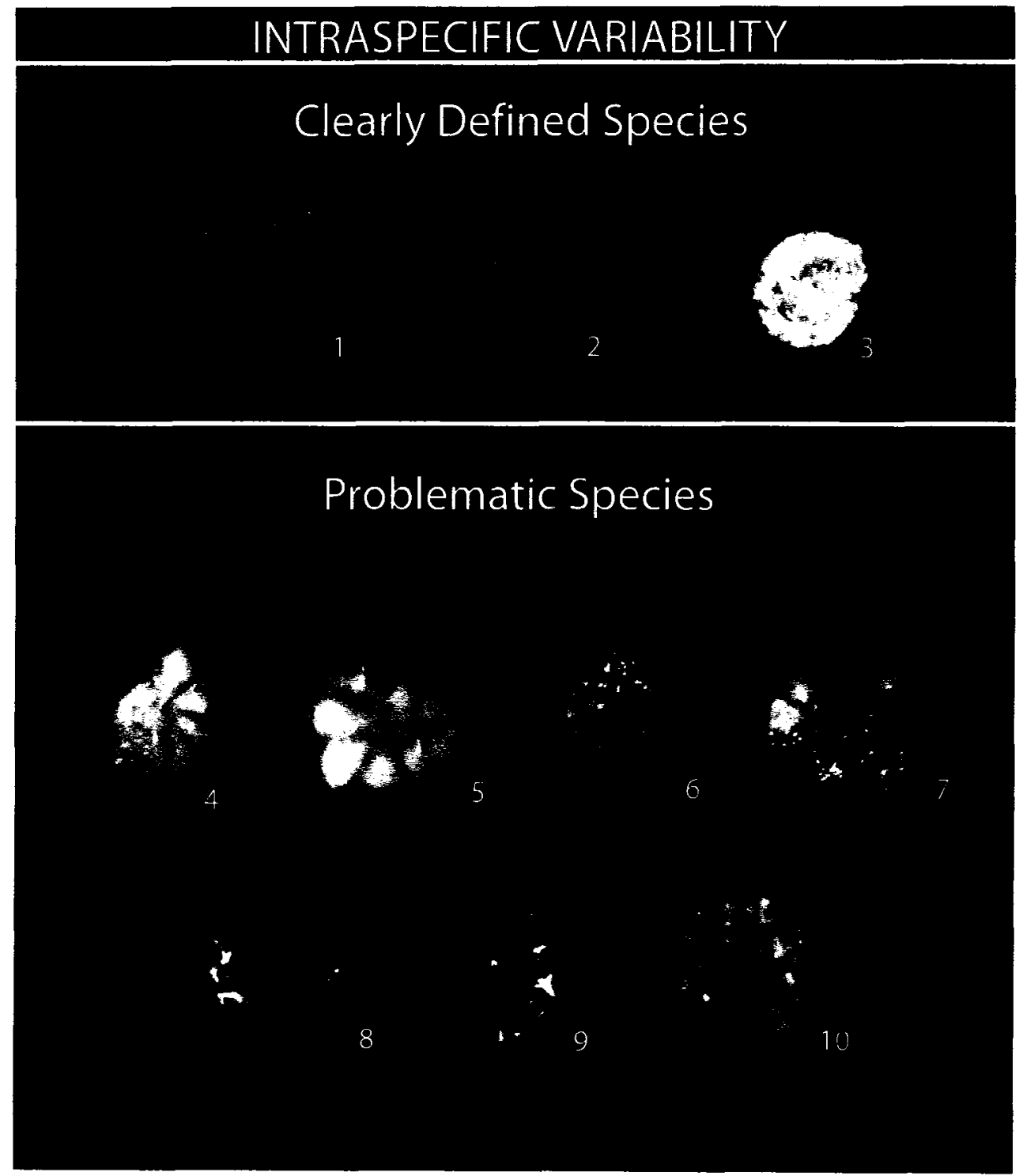

Figure 7. Species 1. Haplophragmoides postis goodrichi, 2. Haplophragmoides linki, and 3. Haplophragmoides multiplum are well defined and easily identified taxonomically. Species 4-10 are all variations of Haplophragmoides postis found within the PR-2001-G3 sample from Moberly Lake Road. Note the various degree of distortion, overgrowth and silicification. 


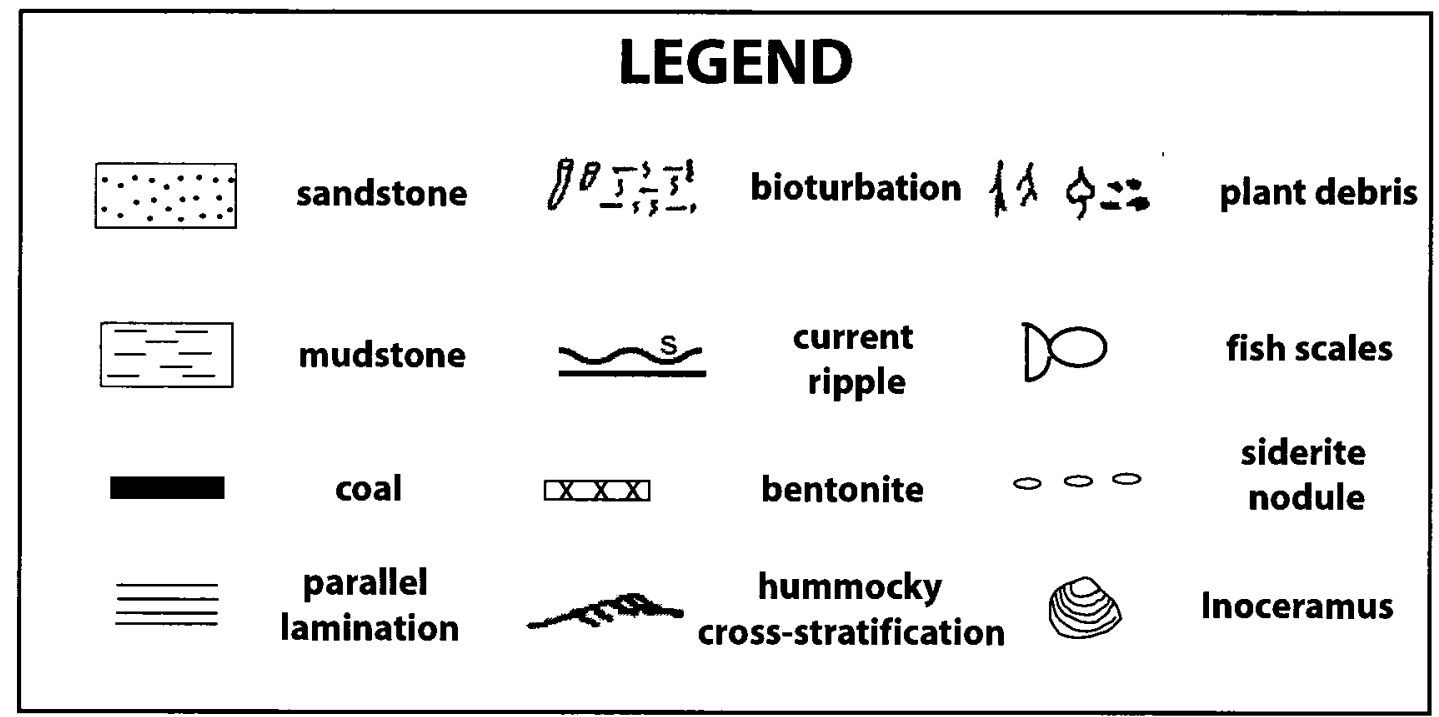

Figure 8. Legend for stratigraphic columns 


\section{RESULTS}

Stratigraphic sections for outcrops and cores show foraminiferal sample locations, allostratigraphic surfaces and allomembers (Roca 2007) and facies. Foraminiferal faunas found in each section and core are subdivided into assemblages. Assemblage boundaries were defined on the basis of changes in foraminiferal abundance and species composition. Assemblage changes coincide with allostratigraphic erosional surfaces and will be described in relation to allomembers. All species are figured in Plates 1-5 and tables of actual counts are in the appendix. Foraminiferal species are exclusively agglutinated with the exception of one specimen found in the Mount Belcourt outcrop that had a calcareous test.

Individual facies are described by their sedimentary structures, ichnofossils, grain size and inferred depositional environment in table 2 . The facies are fully marine sediments ranging from shelf to lower shoreface, with the exception of a coal bed in the Deadhorse Meadows outcrop.

\section{Deadhorse Meadows}

The Deadhorse Meadows outcrop lies in northwestern Alberta at 54 deg 08' 53 ' ' N and 119 deg 53'24' W (figure 1 and table 1). The section can only be reached via helicopter and records an expanded section with the most complete coverage available for this study. 


\begin{tabular}{|c|c|c|c|c|c|c|}
\hline NO. & Facies & Texture & Sedimentary structures & $\begin{array}{c}\text { Vertical } \\
\text { Sequence }\end{array}$ & $\begin{array}{c}\text { Degree of } \\
\text { Bioturbation }\end{array}$ & $\begin{array}{c}\text { Inferred } \\
\text { Depositional } \\
\text { Environment }\end{array}$ \\
\hline I & Mudstone & Silt and clay & $\begin{array}{l}\text { Mainly homogeneous and } \\
\text { structureless, parallel laminations } \\
\text { uncommon. Siderite concretions common. }\end{array}$ & None & None & $\begin{array}{l}\text { Lower } \\
\text { offshore } \\
\text { to shelf }\end{array}$ \\
\hline II & $\begin{array}{l}\text { Siltstone } \\
\text { interbedded } \\
\text { w/ fine } \\
\text { sandstone } \\
\end{array}$ & $\begin{array}{l}\text { Silt and } \\
\text { very fine } \\
\text { to fine } \\
\text { sands }\end{array}$ & $\begin{array}{l}\text { Siltstone structureless or laminated; } \\
\text { Sands planar and laterally continuous. } \\
\text { Siderite concretions common. }\end{array}$ & $\begin{array}{l}\text { Gradual } \\
\text { upwards } \\
\text { coarsening }\end{array}$ & $\begin{array}{l}\text { Uncommon } \\
\text { Skolithos } \\
\text { Cruziana }\end{array}$ & $\begin{array}{l}\text { Lower } \\
\text { offshore }\end{array}$ \\
\hline III & $\begin{array}{l}\text { Fine } \\
\text { sandstone } \\
\text { interbedded } \\
\text { w/ siltstone }\end{array}$ & $\begin{array}{l}\text { Fine to } \\
\text { medium } \\
\text { sands } \\
\text { and silt }\end{array}$ & $\begin{array}{l}\text { Sandstone beds } 1-5 \mathrm{~cm} \text { thick laterally continuous, } \\
\text { often with starved or wave ripples. } \\
\text { Beds coarsen upwards to medium sandstone, } \\
\text { often hummocky cross-stratified. } \\
\text { Commonly contains many coarsening } \\
\text { upwards cycles. }\end{array}$ & $\begin{array}{l}\text { Gradual } \\
\text { upwards } \\
\text { coarsening }\end{array}$ & $\begin{array}{l}\text { Locally intense } \\
\text { bioturbation } \\
\text { In some } \\
\text { sequences } \\
\text { Skolithos }\end{array}$ & $\begin{array}{l}\text { Upper } \\
\text { offshore }\end{array}$ \\
\hline IV & $\begin{array}{l}\text { Fine } \\
\text { sandstone }\end{array}$ & $\begin{array}{l}\text { Fine to } \\
\text { medium } \\
\text { grained } \\
\text { sand }\end{array}$ & $\begin{array}{l}\text { Homogeneous and massive with } \\
\text { uncommon medium grained beds. Rarely } \\
\text { Cross-stratified. }\end{array}$ & $\begin{array}{l}\text { Gradually } \\
\text { upwards } \\
\text { coarsening }\end{array}$ & $\begin{array}{l}\text { Moderate to } \\
\text { intense } \\
\text { bioturbation } \\
\text { Skolithos }\end{array}$ & $\begin{array}{l}\text { Lower to } \\
\text { middle } \\
\text { shoreface }\end{array}$ \\
\hline $\mathrm{V}$ & coal & lignite & Homogeneous $2 \mathrm{~cm}$ seam. & None & None & $\begin{array}{l}\text { Swamp } \\
\text { Marsh }\end{array}$ \\
\hline VI & $\begin{array}{l}\text { Lag \& } \\
\text { related } \\
\text { facies }\end{array}$ & $\begin{array}{l}\text { Medium } \\
\text { sand to } \\
\text { conglomerate }\end{array}$ & $\begin{array}{l}\text { Quartz and chert pebbles up to } 15 \mathrm{~mm} \text { thick } \\
\text { wave rippled or homogeneous, often } \\
\text { containing gutter casts. Wood fragments, } \\
\text { fish scales and bone fragments common } \\
\text { to abundant. }\end{array}$ & None & $\begin{array}{l}\text { Absent or } \\
\text { intense } \\
\text { Skolithos }\end{array}$ & $\begin{array}{c}\text { Not } \\
\text { applicable }\end{array}$ \\
\hline
\end{tabular}

Table 2. Six Facies (I to VI) are defined by their features of texture, stratification and ichnofossil content. The right column is the inferred depositional environment (after Cliftone, 1986). 


\section{Lithology:}

The section at Deadhorse Meadows comprises $420 \mathrm{~m}$ of strata from the VE4 to the FSU surface and the overlying Dunvegan Formation (figure 9). The outcrop lies unconformably on sandstone of Boulder Creek Formation (figure 10a) and consists predominately of dark grey platy mudstone interbedded with very fine $2-5 \mathrm{~cm}$ sandstone beds( facies II), with sporadic siderite concretions (figure 10b). Sandstone beds are laterally continuous, often forming small coarsening upwards sequences with wave or starved ripples. Coarsening upwards sequences are often followed by a medium to coarse grained bed that contains Skolithos, pebbles, chert, wood fragments and gutter casts (figure 11a). A $2 \mathrm{~cm}$ coal stringer, WE1 surface, is also present at $42 \mathrm{~m}$ (figure 11b). From $95 \mathrm{~m}$ to $115 \mathrm{~m}$ the lithology consists of grey mudstone with continuously interbedded very fine sandstone with some bioturbation but mostly well laminated (facies II). Fish scales are present throughout this interval and become very abundant at the top $(115 \mathrm{~m})$ where Inoceramus fragments and pyritized wood (figure 12a) are present in an intensely bioturbated zone $20 \mathrm{~cm}$ thick.

Above $115 \mathrm{~m}$ the section consists mainly of dark grey platy mudstone (facies I) that contains siderite concretions. This siltstone lacks bioturbation even in the intervals that contain very fine to fine grained interbedded sandstone beds (facies III), often containing starved ripples. The overlying Dunvegan Formation lies unconformably above this interval (figure 12b).

\section{Micropaleontology:}

The foraminifera found in the Deadhorse Meadows section were subdivided into five assemblages, which were defined on the basis of changes in foraminiferal 


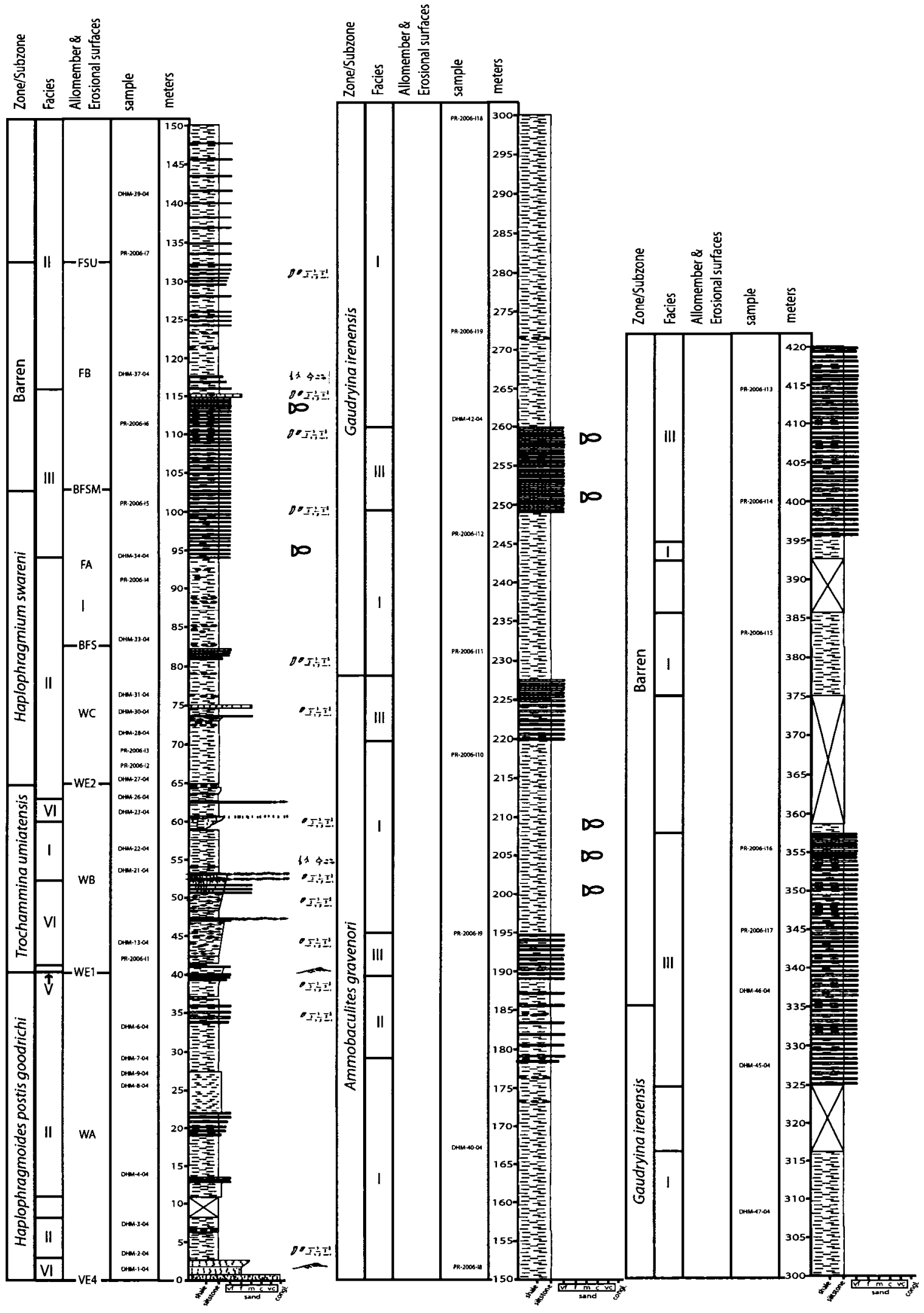

Figure 9. Deadhorse Meadows section showing sample locations, erosional surfaces (Roca 2007), facies and foraminiferal zones. Refer to legend in figure 8. Allomembers above the FSU erosional surface have not been assigned and are therefore not labeled. 

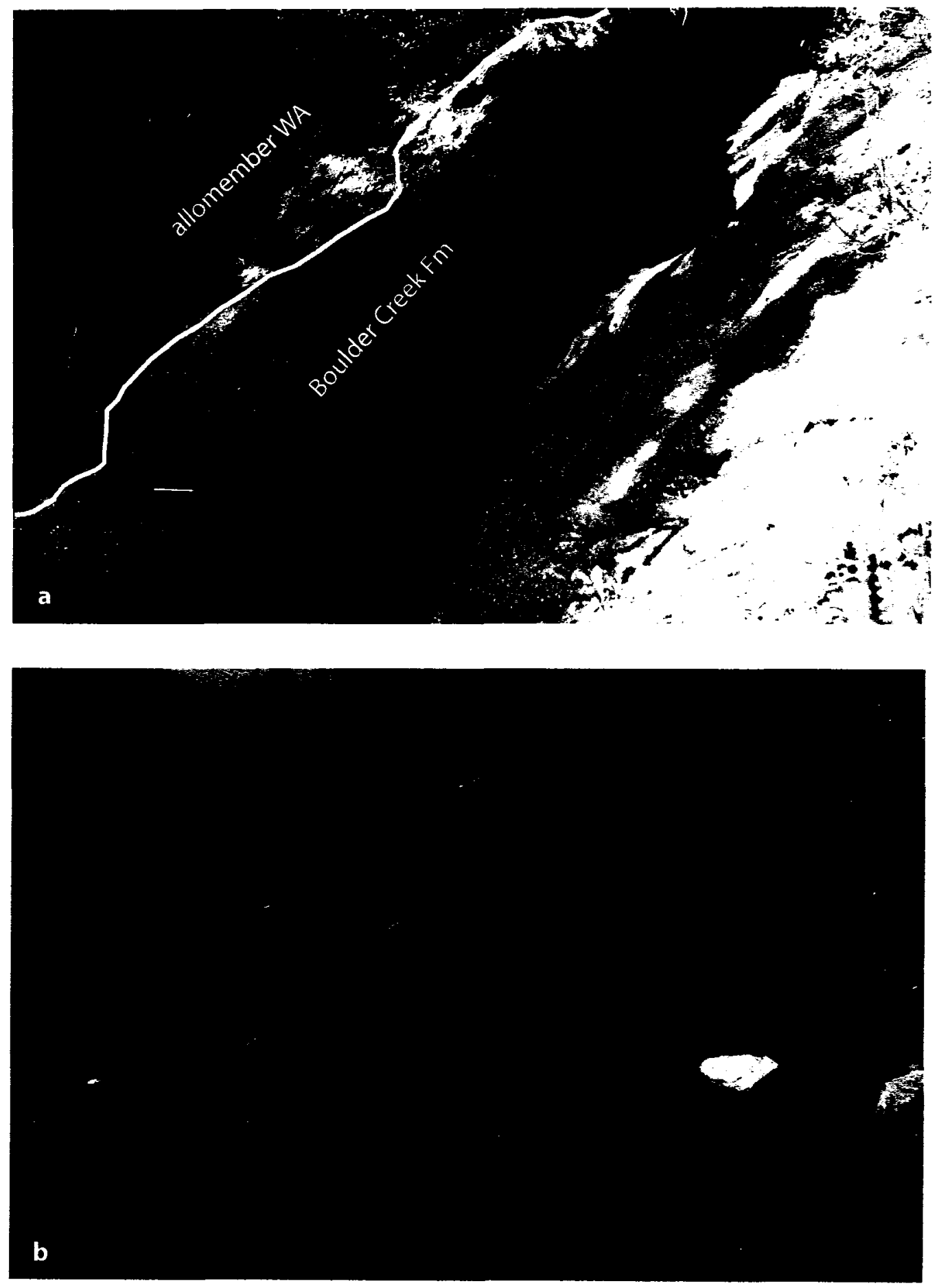

Figure 10. Deadhorse Meadows section: a. basal allomember WA lying unconformably over the Boulder Creek Formation $b$. dark grey mudstone with interbedded fine sandstone of allomember WB. 

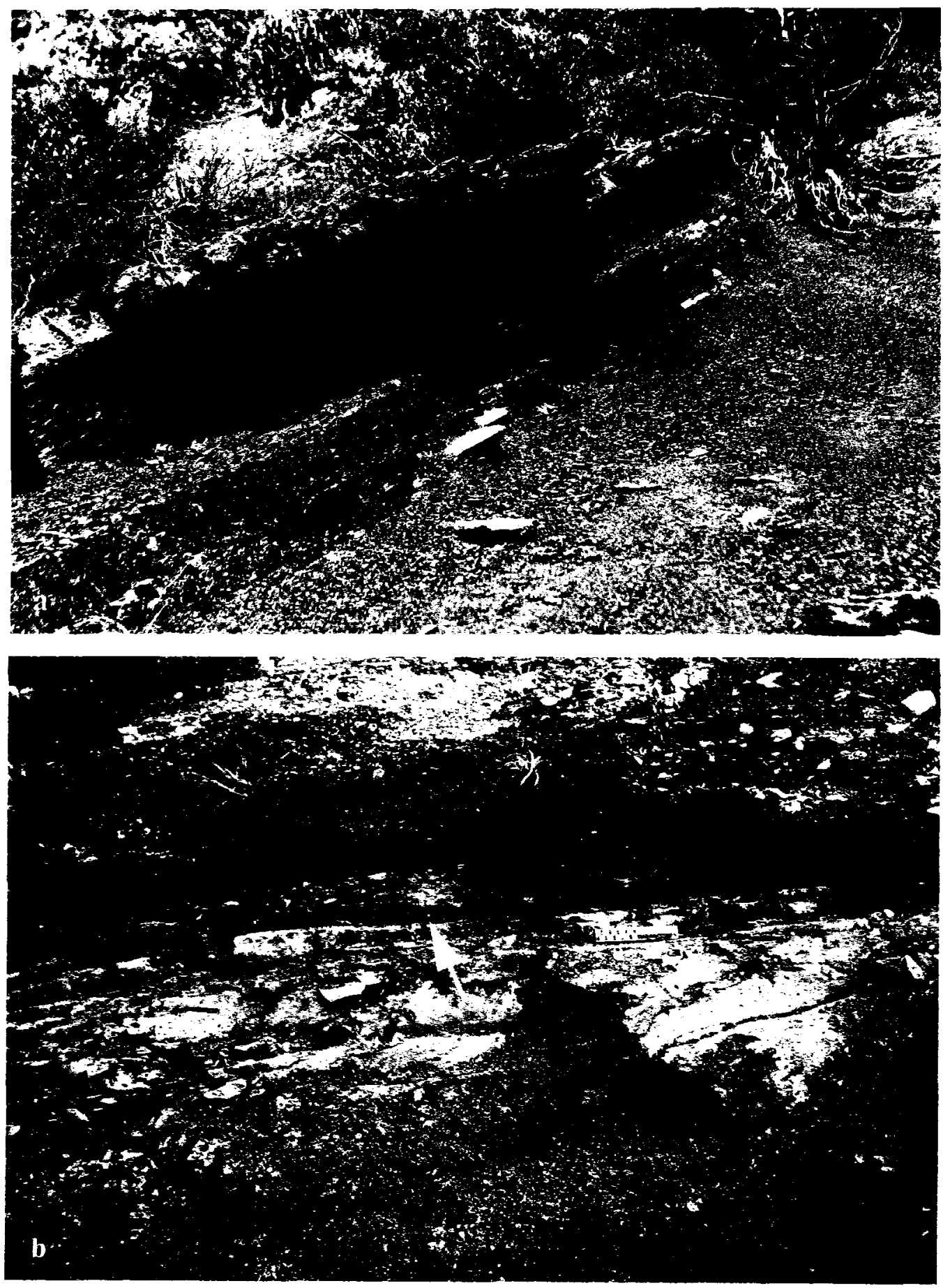

Figure 11. Deadhorse Meadows section: a. coarsening upwards sequence with a medium grained sandstone at the top of allomember WB b. $2 \mathrm{~cm}$ coal bed at WE1 surface indicated by the white arrow. 

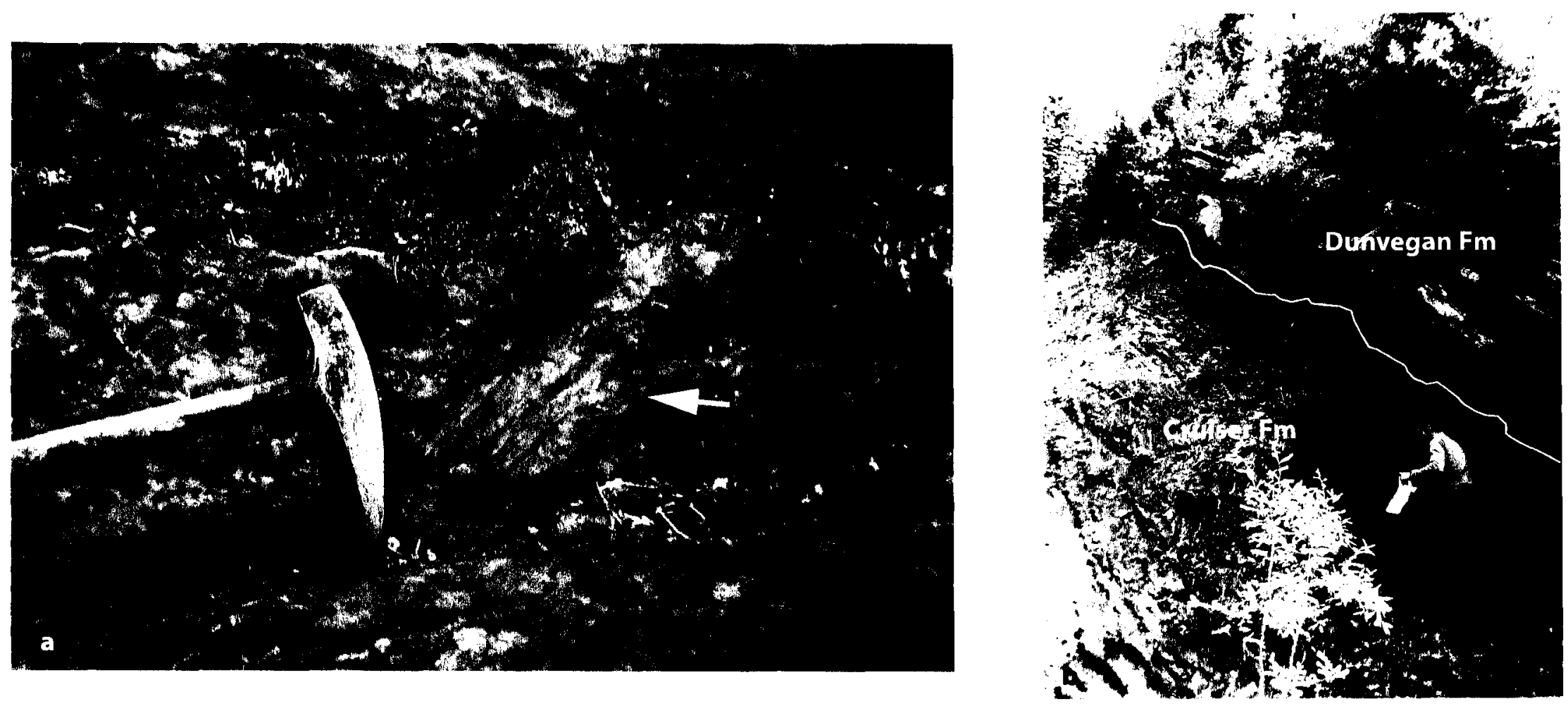

Figure 12. Deadhorse Meadows section: a. Pyritized wood fragment in allomember FB b. unconformable contact of Cruiser Formation with overlying Dunvegan Formation. 
composition. Since the Deadhorse Meadows section covers a long stratigraphic interval and is nearly complete, it will serve as a reference section to establish foraminiferal zones that are then correlated to allomembers.

\section{Haplophragmoides postis goodrichi Zone}

The lowest faunal zone in the Deadhorse Meadows outcrop falls within the WA allomember (figure 9) between the VE4 and WE1 surfaces spanning the interval from $0 \mathrm{~m}$ to $42 \mathrm{~m}$ below a $2 \mathrm{~cm}$ coal bed. The zone contains 18 species, of which, Haplophragmoides postis goodrichi, is most abundant and unique to this zone. Foraminiferal abundances within this interval range from 19 to 206 specimens per sample. Biostratigraphic ranges and species abundances for the Deadhorse Meadows section are in figure 13. The common (5-19 specimens) and abundant ( $>19$ specimens) taxa are within this zone are listed below.

Haplophragmoides postis goodrichi, Ammobaculites fragmentarius, Ammobaculites tyrrelli, Miliammina sproulei, Saccammina alexanderi, Trochammina rutherfordi and Miliammina manitobensis

\section{Trochammina umiatensis Zone}

The second faunal zone (figure 13) appears above the coal bed at $42 \mathrm{~m}$ and ranges to a glauconitic medium grained sandstone containing small pebbles at $64 \mathrm{~m}$ and corresponds to allomember WB between the WE1 and WE2 surfaces (figure 9). The species Haplophragmoides postis goodrichi and Trochammina rutherfordi that were abundant below are no longer present in this interval. Trochammina umiatensis is designated as the indicator species due to its first appearance and abundance in allomember WB. This zone contains 16 different species with foraminiferal 


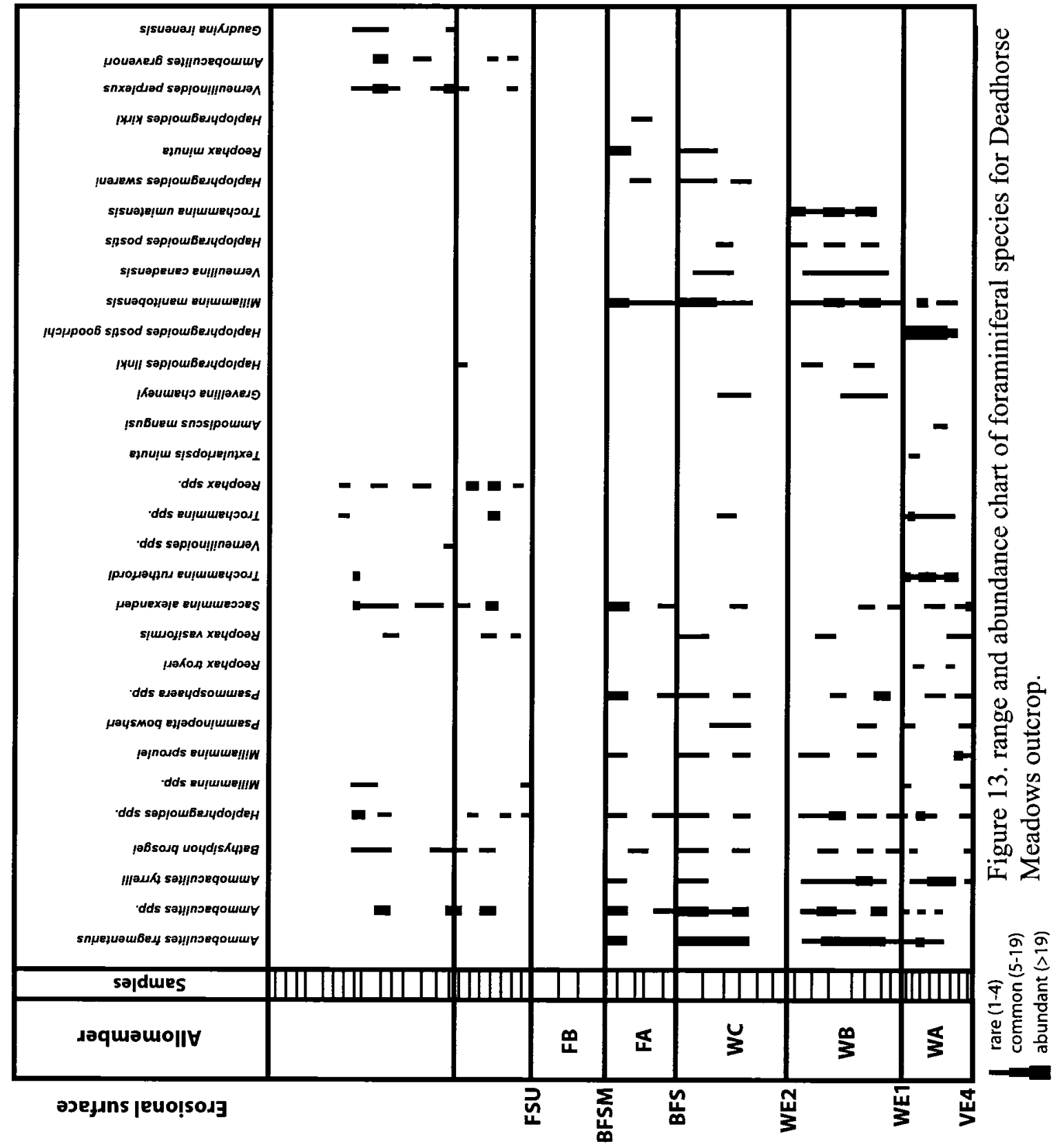


abundance ranging from 4 to 60 specimens per sample (figure 13). Common and abundant taxa include

Trochammina umiatensis, Ammobaculites fragmentarius, Ammobaculites tyrrelli, Miliammina manitobensis, Verneuilina Canadensis, Psammosphaera spp. and Haplophragmoides postis

\section{Haplophragmium swareni Zone}

The third zone follows a barren interval from $64 \mathrm{~m}$ to $71 \mathrm{~m}$ and ranges from $71 \mathrm{~m}$ to $94 \mathrm{~m}$. This zone is associated with allomembers WC and FA and falls between the WE2 and FSMB surfaces (figure 9). The species Haplophragmium swareni first appears in this zone and is given indicator status, while Trochammina umiatensis is no longer present (figure 13). This assemblage contains 18 species with abundance ranging from 8 to 74 specimens per sample. Common and abundant taxa in this assemblage include: Ammobaculites fragmentarius, Ammobaculites tyrrelli, Saccammina alexanderi, Miliammina manitobensis and Reophax minuta.

\section{Verneuilinoides perplexus Zone}

\section{Ammobaculites gravenori Subzone}

The interval from $94 \mathrm{~m}$ to $134 \mathrm{~m}$ (associated with allomember FB) has two coarsening upwards cycles with abundant fish scales, intense bioturbation, wave rippled fine sandstones, but is barren of foraminifera. The incoming foraminiferal zone falls above the allomembers defined by Roca (2007) but is associated with the Ammobaculites gravenori Subzone of the Verneuilinoides perplexus Zone. This subzone occurs from 134 $\mathrm{m}$ to $227 \mathrm{~m}$ and contains five species. Abundances range from 4 to 40 specimens per sample (figure 13). The common and abundant taxa include: 
Saccammina alexanderi, Verneuilinoides perplexus and Reophax spp.

Verneuilinoides perplexus Zone

Gaudryina irenensis Subzone

The youngest strata contains Gaudryina irenensis, the upper subzonal marker of the Verneuilinoides perplexus Zone. This subzone occurs from $227 \mathrm{~m}$ to $345 \mathrm{~m}$ were the section becomes barren up to the Dunvegan Formation that unconformably overlies the study interval. There are eight species present within this assemblage and total abundances range from 2 to 44 specimens per sample (figure 13). The common and abundant taxa include:

Ammobaculites gravenori, Gaudryina irenensis, Saccammina alexanderi, Verneuilinoides perplexus, Reophax spp. and Trochammina rutherfordi

\section{Nickerson Creek}

The Nickerson Creek outcrop lies southeast of Deadhorse Meadows at 54 deg 01'42' $\mathrm{N}$ and $119 \mathrm{deg} 28^{\prime} 06$ ' 'W (figure 1 and table 1). This section lies $24 \mathrm{~km}$ northwest of Grande Cache, Alberta off Highway 40. It can be reached by four-wheeldrive vehicle off a logging road just northwest of Grande Cache.

\section{Lithology:}

The Nickerson Creek outcrop is a $105 \mathrm{~m}$ section (figure 14) and spans the interval from the VE4 surface at the base of the WA allomember to the FB allomember (figure 15). The basal four meters of this section is medium to coarse grained sandstone (facies IV) with symmetrical wave ripples. The remaining $100 \mathrm{~m}$ are mudstone with abundant 


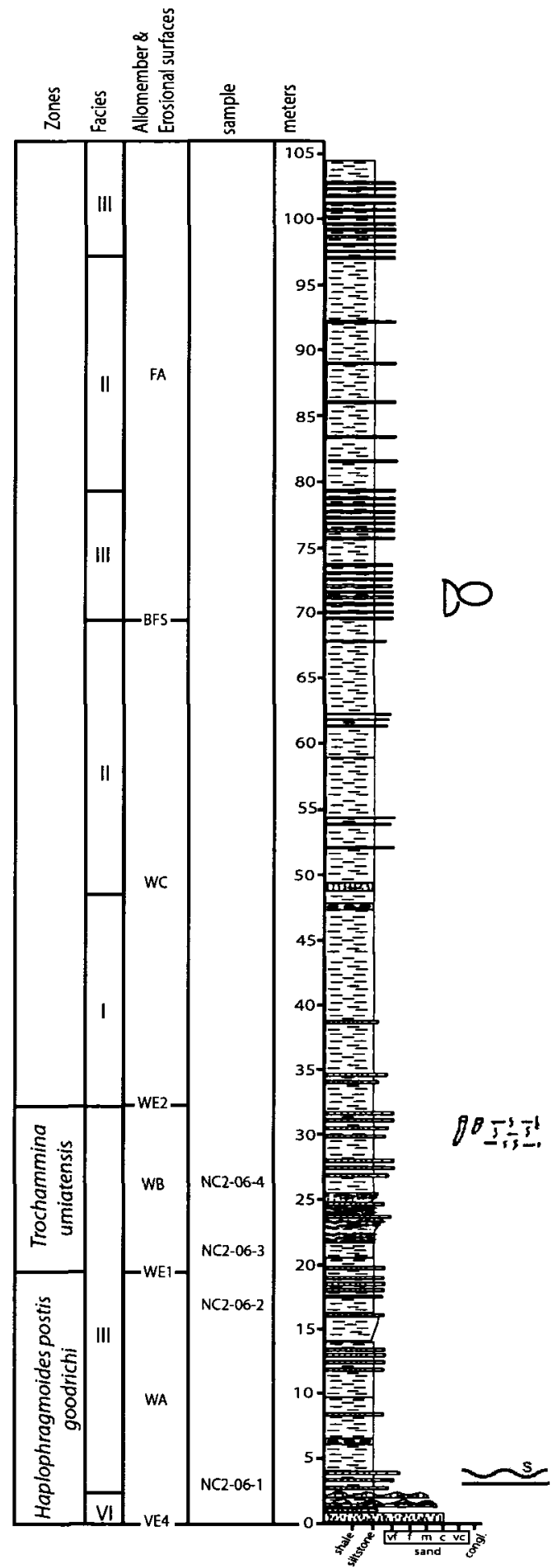

Figure 14. Stratigraphic section of Nickerson Creek with location of foraminiferal samples, allostratigraphic surfaces (Roca, 2007), facies and foraminiferal zones (refer to legend: figure 8). 


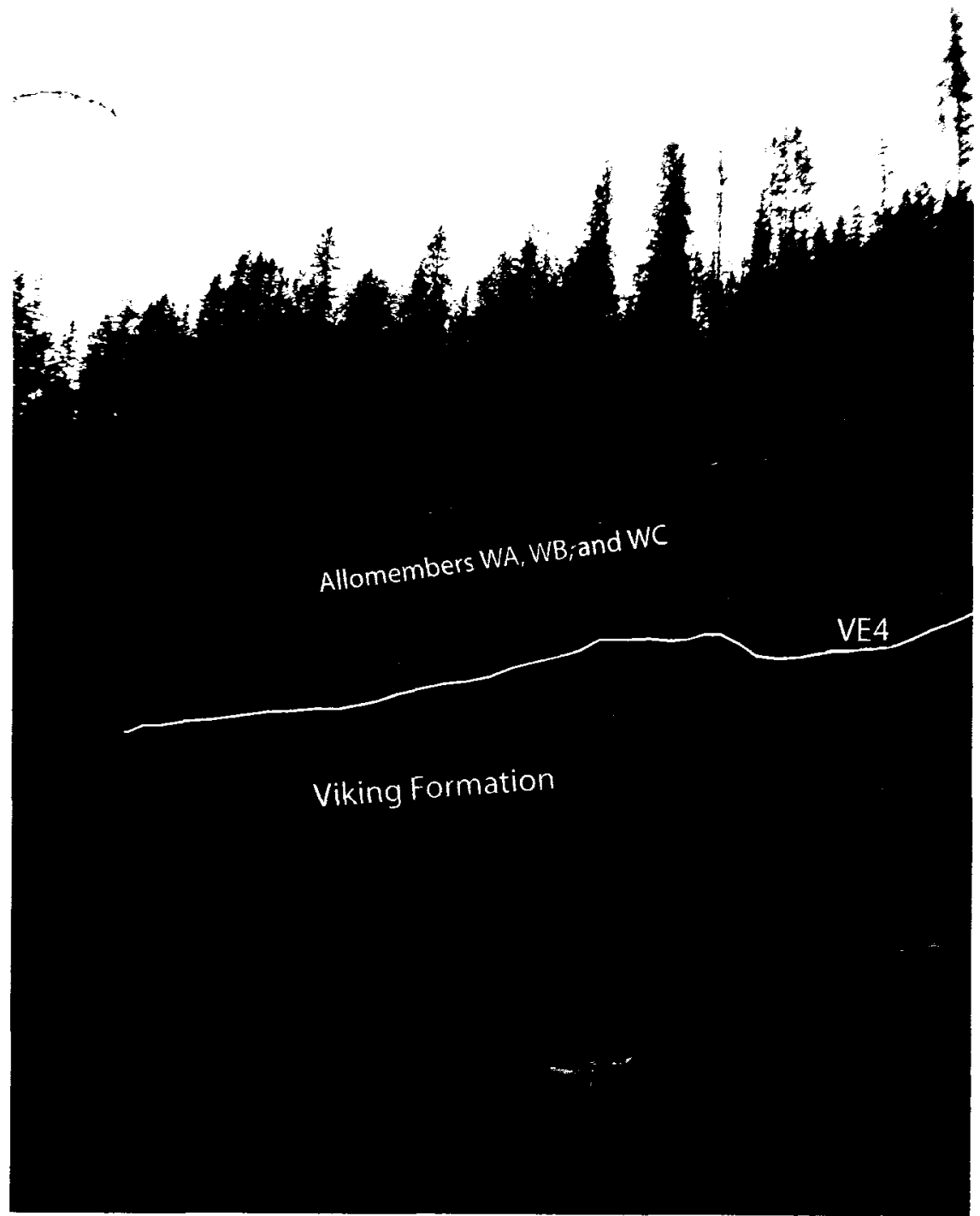

Figure 15. Outcrop photo of the Nickerson Creek locality showing the unconformable contact between Viking Formation and the over-lying allomembers above the VE4 surface. 
very fine grained $2-5 \mathrm{~cm}$ thick sandstone beds (facies II), showing coarsening upwards cycles to very fine grained sandstone.

\section{Micropaleontology:}

Samples taken in the Nickerson Creek outcrop lie between the VE4 and the WE2 surfaces. The Haplophragmoides postis goodrichi assemblage occurs in the coarse interval between the VE4 and the WE1 surfaces (figure 14). The Haplophragmoides postis goodrichi assemblage contains ten different species with Haplophragmoides postis goodrichi being the dominant species. Foraminiferal species abundances range from 17 and 91 specimens. The Trochammina umiatensis assemblage occurs from $17 \mathrm{~m}$ to $33 \mathrm{~m}$ (figure 14) and contains 18 different species with abundances of 41 and 90 specimens. Foraminiferal abundance and ranges are shown in figure 16.

\section{Sulphur River}

The Sulphur River outcrop is southeast of Nickerson Creek at 53 deg 72'14' N and 119 deg 03'33' 'W (figure 1 and table 1) and is $32 \mathrm{~km}$ southwest of Grande Cache, Alberta.

\section{Lithology:}

The Sulphur River outcrop is a $108 \mathrm{~m}$ long section (figure 17) of allomembers VD, WA, WB, WC and FB (figure 18). The basal eight meters (VD) are fine to medium grained cross-stratified sandstone (facies IV) with a thin $10-15 \mathrm{~cm}$ conglomeratic bed at the top, representing the VE4 surface (figure 17). From 8 to $20 \mathrm{~m}$ the section consists of four coarsening upwards cycles grading from mudstone to very fine grained sandstone 

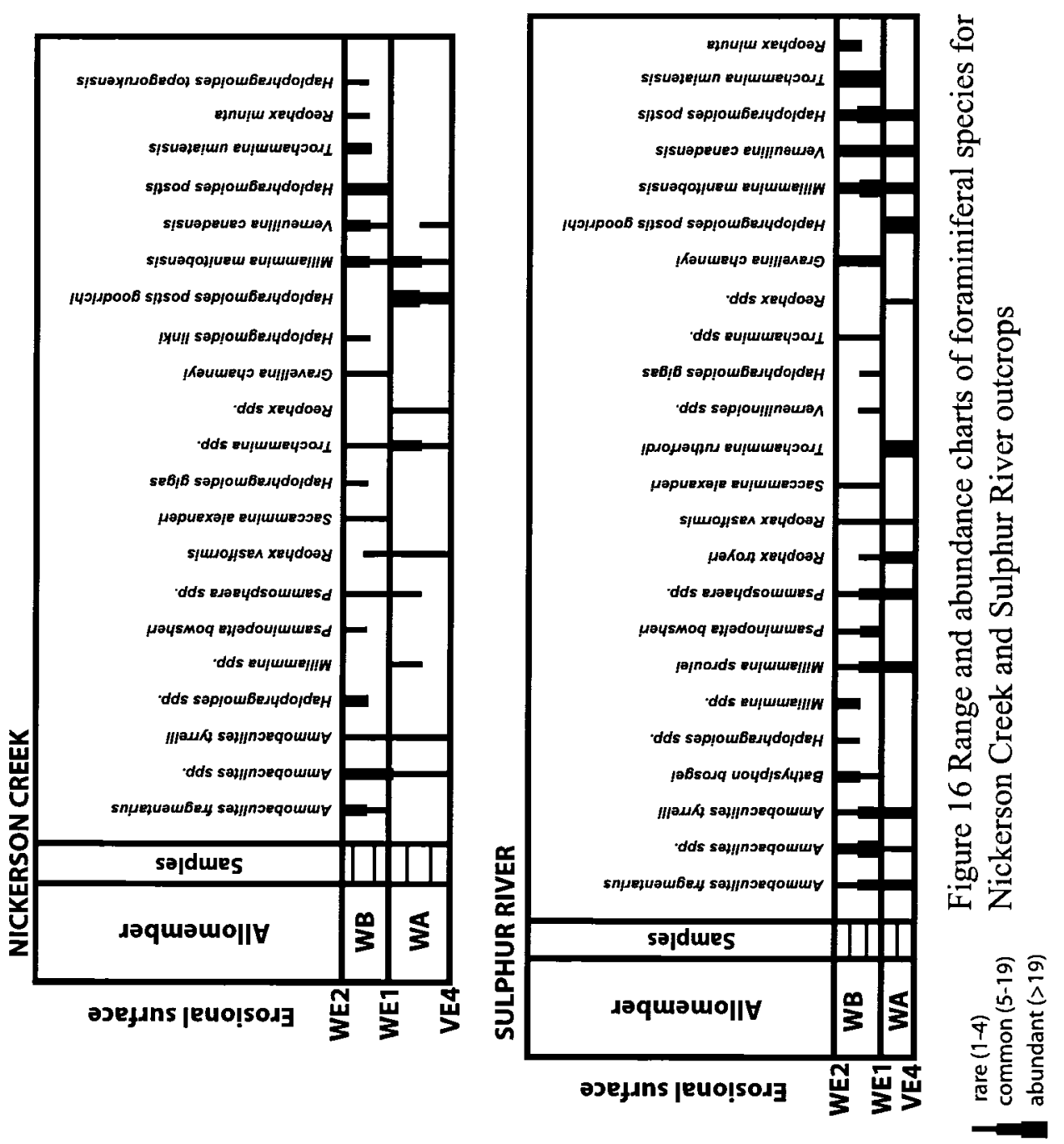


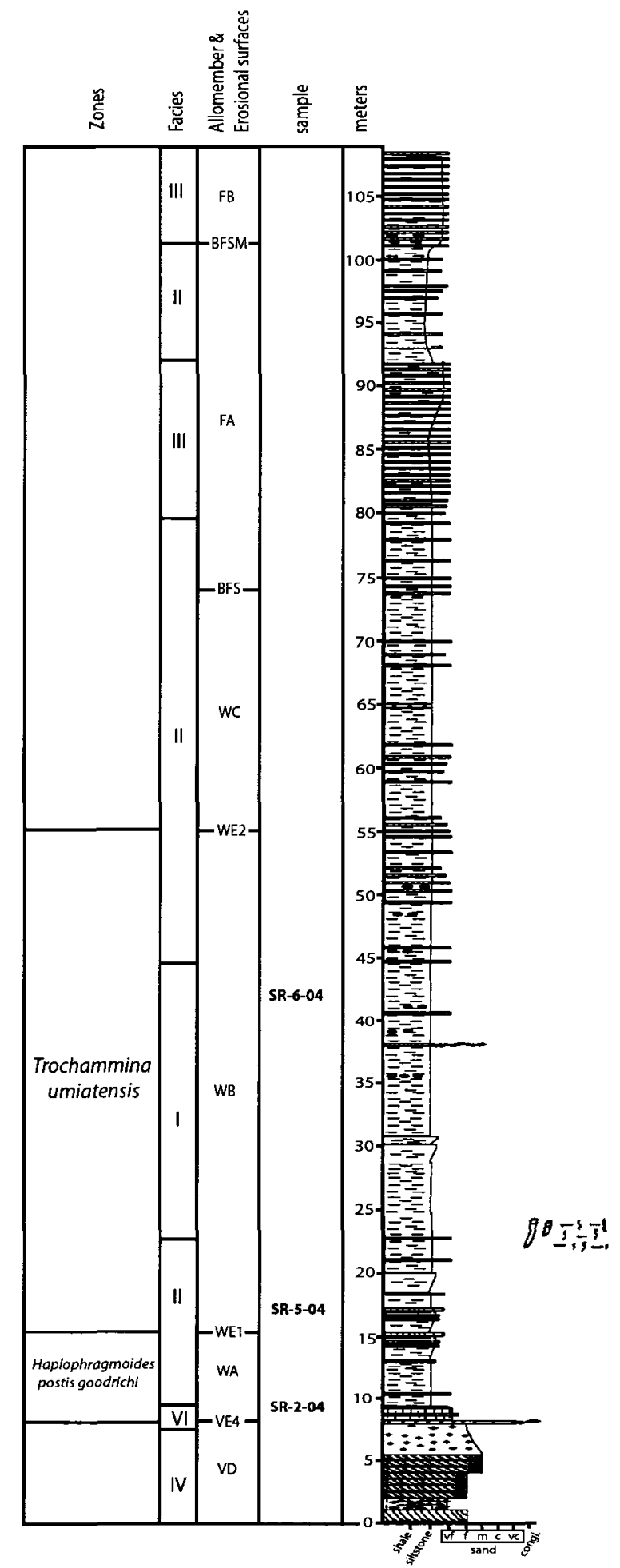

Figure 17. Stratigraphic section of the Sulphur River section with location of foraminiferal samples, allostratigraphic surfaces (Roca 2007), facies and foraminiferal zones. Refer to legend: figure 8. 


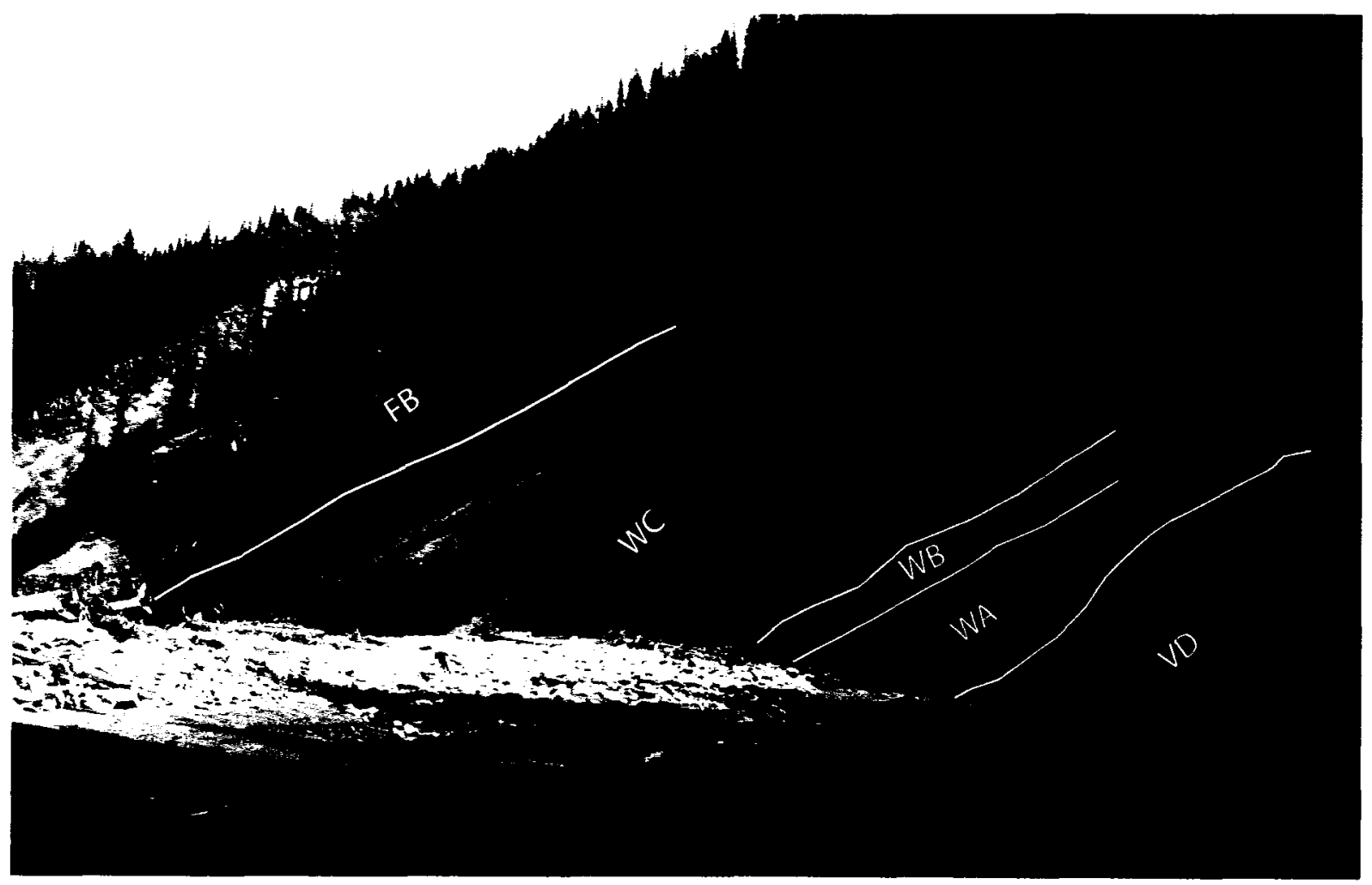

Figure 18. Outcrop photograph at the Sulphur River section showing allomembers VD, WA, WB, WC and FB (from Roca, 2007). 
(facies II to III). The remaining section is mostly siltstone with interbedded very fine grained sandstone beds $(1-4 \mathrm{~cm})$ that often coarsen upwards (facies II).

\section{Micropaleontology:}

The Haplophragmoides postis goodrichi assemblage occurs in allomember WA from eight to $15 \mathrm{~m}$ lying between VE4 and WE1 (figure 17). The assemblage contains 13 species but is $53 \%$ dominated by Haplophragmoides postis goodrichi. The Trochammina umiatensis assemblage occurs from $15 \mathrm{~m}$ to $55 \mathrm{~m}$ (figure 17). The Trochammina umiatensis assemblage contains 21 species including Ammobaculites fragmentarius, Ammobaculites tyrrelli, Miliammina manitobensis, and Verneuilinoides canadensis. Foraminiferal abundance and biostratigraphic ranges are shown in figure 16.

\section{Mount Belcourt}

The Mount Belcourt outcrop lies northeast British Columbia at 54 deg 25'49' N and 120 deg 27'36' W on the north facing slope of Mt. Belcourt (figure 1 and table 1). This outcrop can only be reached via helicopter.

\section{Lithology:}

The $315 \mathrm{~m}$ thick Mount Belcourt section (figure 19) includes strata of allomembers VD, WA and WB that are overlain by the Goodrich Formation (figure 20a). The outcrop sits unconformably over the Boulder Creek Formation (figure 20b) and consists predominately of dark grey, parallel laminated mudstone (figure 21a) interbedded with laterally continuous very fine grained $2-5 \mathrm{~cm}$ thick sandstone beds (facies II; figure 21b), with sporadic siderite concretions. Sandstone beds often form small coarsening upwards sequences, from mudstone to fine sandstone, (figure $21 \mathrm{~b}$ ) with 


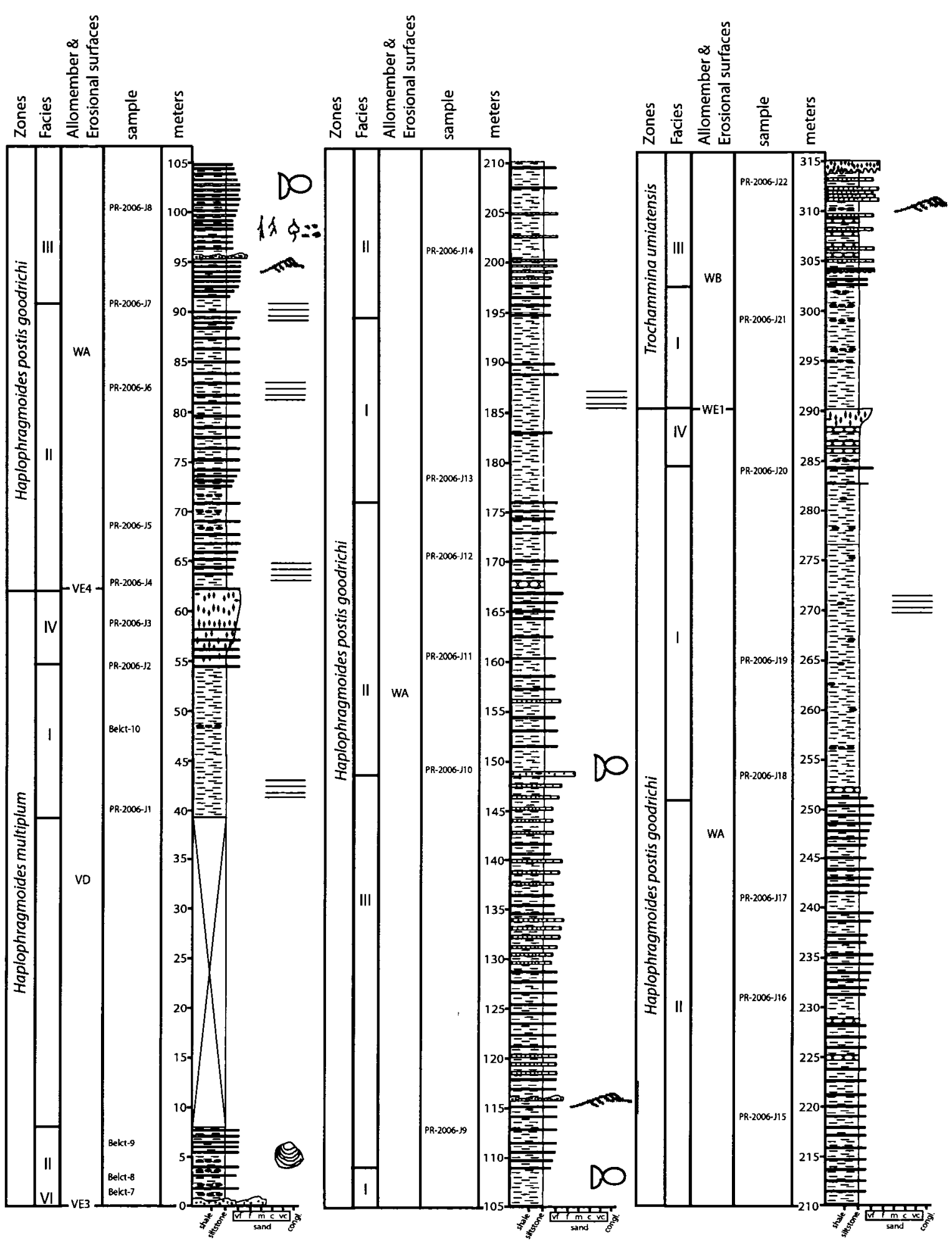

Figure 19. Stratigraphic section of the outcrop at Mount Belcourt with location of foraminiferal samples, allostratigraphic surfaces, facies and foraminiferal zones (refer to legend: figure 8). 

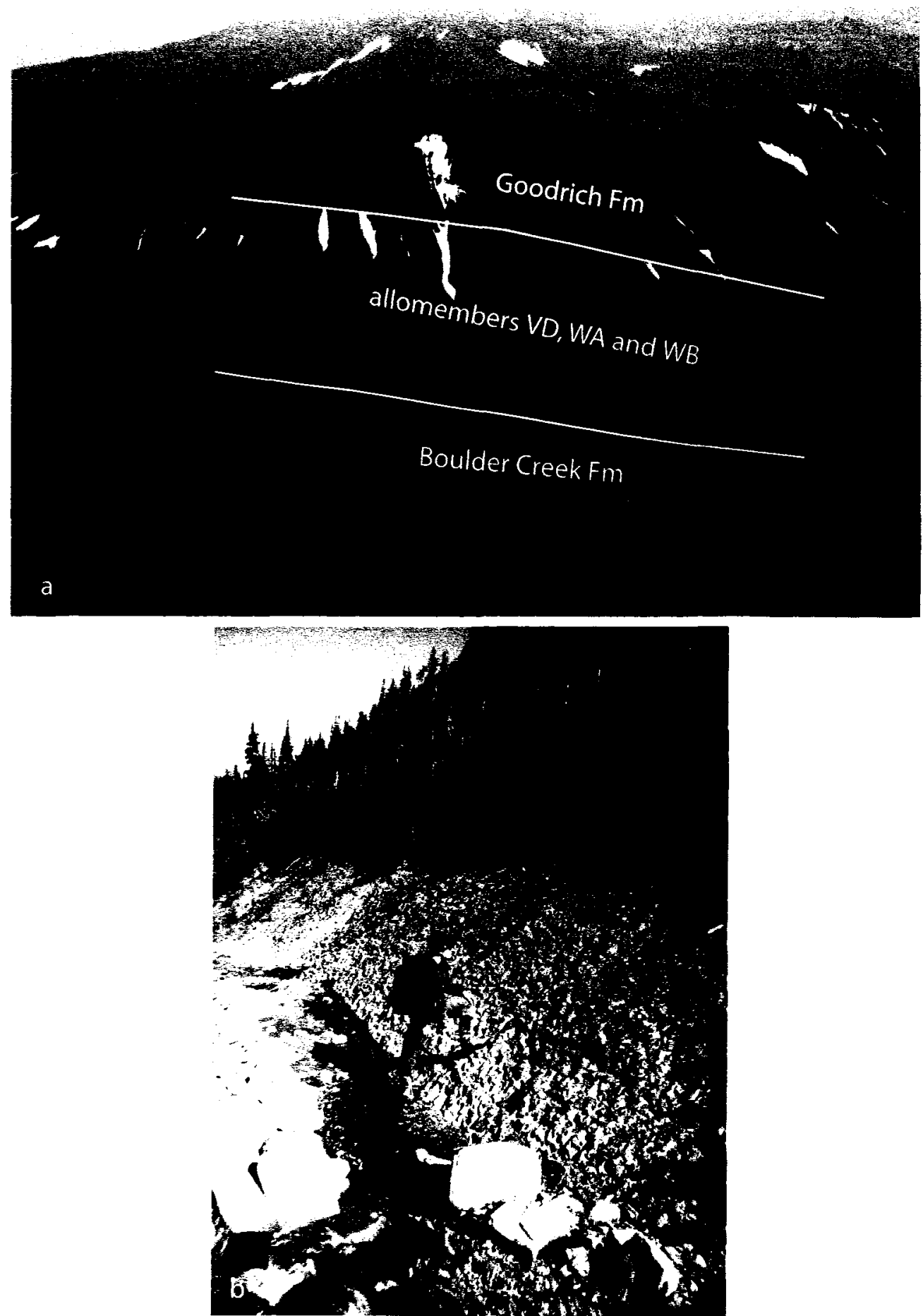

Figure 20. Outcrop photos of Mt. Belcourt. a) Spectacular outcrop exposure of allomembers VD, WA and WB lying between the Boulder Creek and Goodrich formations. b) Conglomerate unconformity with $8 \mathrm{~cm}$ of relief between Boulder Creek Formation and the VD allomember at the base of the Mt. Belcourt outcrop. 

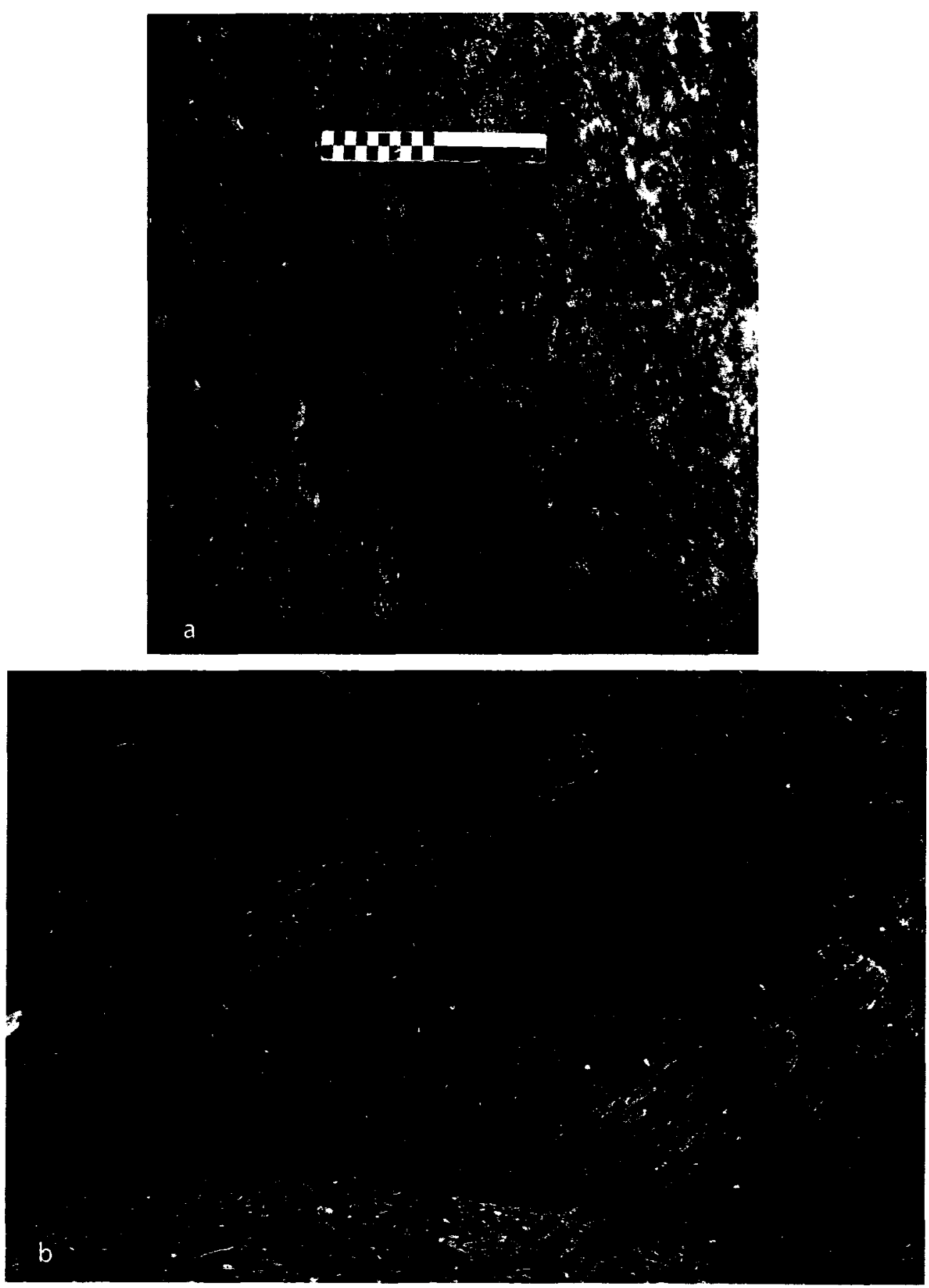

Figure 21. Outcrop photos of Mt Belcourt. a) Parallel lamination in dark grey siltstone seen in a streambed in allomember WA. b) Laterally continuous very fine sandstone beds with coarsening upwards cycles in the WB allomember. 
wave rippled tops. Bioturbation is absent within the fine and coarse intervals of the outcrop or cannot be identified due to lack of sediment contrast.

Inoceramus shells are present in the basal nine meters of section (figure 22a) followed by a $30 \mathrm{~m}$ covered interval. Abundant very fine grained sandstone beds containing coarsening upwards cycles are prevalent through the remaining section (facies III). Coarsening upwards cycles culminate in medium grained, hummocky crossstratified sandstone (facies III) at $95 \mathrm{~m}$ and $116 \mathrm{~m}$. Mudstone intervals in-between coarse cycles show parallel lamination (facies I and II). A number of small 2-4 cm thick bentonites are present above $225 \mathrm{~m}$ and become increasingly common near the top of the section with increasing sandstone content. The Goodrich Formation unconformably overlies allomember WB (figure 22b).

\section{Micropaleontology:}

\section{Haplophragmoides multiplum Zone}

The Haplophragmoides multiplum Zone is stratigraphically the lowest zone present in the study area. It occurs in the VD allomember between the VE3 and VE4 surfaces (figure 4). Haplophragmoides multiplum is a subzonal marker of the Gaudryina nanushukensis Zone, and associated with the Middle Albian Hulcross/Harmon formations after the zonation proposed by Caldwell et al. (1978). Within the studied stratigraphic interval its last appearance datum occurs consistently within the allomember VD and therefore has been chosen here as a zonal marker despite its first appearance datum in the Middle Albian. The Haplophragmoides multiplum Zone is recognized in the Moberly Lake Road, Halfway River and Mount Belcourt outcrops. Species occurring commonly (5-19 specimens) and abundantly (>19 specimens) are listed below. 


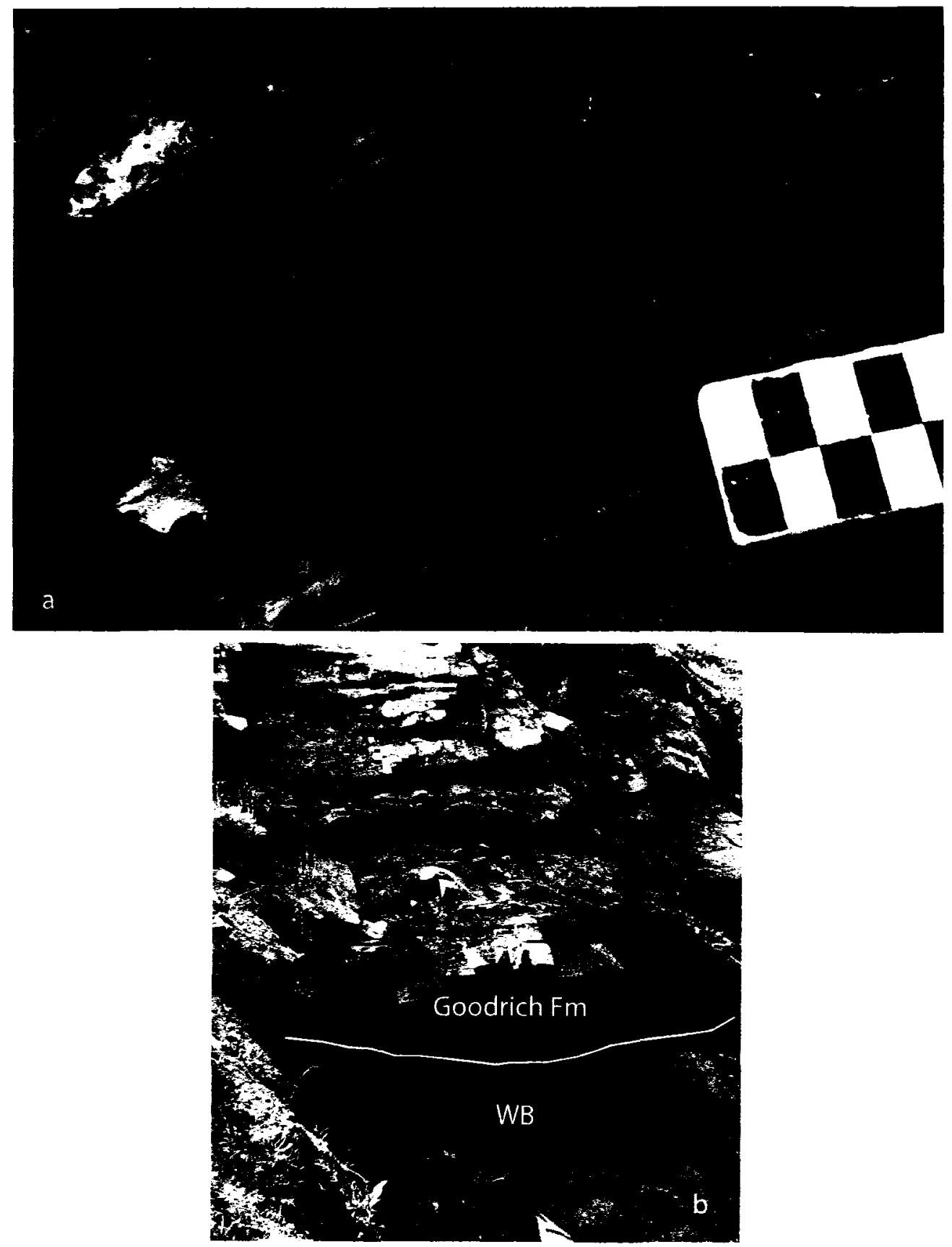

Figure 22. Outcrop photos of Mt. Belcourt. a) impression of an Inoceramus shell in the lower VD allomember. b) Unconformity between the WB allomember and Goodrich Formation. 
Haplophragmoides multiplum, Ammobaculites fragmentarius, Ammobaculites tyrrelli, Miliammina sproulei, Psamminopelta bowsheri, Trochammina rutherfordi and Haplophragmoides postis

The Haplophragmoides multiplum Zone, allomember VD, spans the interval from $0 \mathrm{~m}$ to $55 \mathrm{~m}$. The assemblage contains 19 foraminiferal species with abundances ranging from 9 to 40 specimens per sample (figure 23). Inoceramus prisms are common in this interval with peek abundance at eight meters. At this location the only calcareous foraminiferal taxon present within the study was identified as Lenticulina macrodisca.

The interval from $65 \mathrm{~m}$ to $230 \mathrm{~m}$ (allomember WA) contains common foraminiferal elements including Verneuilina canadensis, Miliammina manitobensis, Ammobaculites fragmentarius and Ammobaculites tyrrelli but no biostratigraphically useful maker species. Within this interval, Inoceramus prisms, fish scales and framboidal pyrite are common. A total of 15 foraminiferal species are present and abundances range from 2-25 specimens per sample (figure 23).

Above a barren interval, at $265 \mathrm{~m}$ the Trochammina umiatensis assemblage is present. The assemblage ranges to the top of the section where the coarser sandstones of the Goodrich Formation appear. The Trochammina umiatensis assemblage contains nine species including Verneuilina canadensis, Bathysiphon brosgei, Gravellina chamneyi, and Trochammina umiatensis. Foraminiferal abundances range from 6 to 14 specimens per sample (figure 23).

\section{Hasler Creek}

The Hasler Creek outcrop lies at $55 \mathrm{deg} 33^{\prime} 40^{\prime \prime}$ N and $121 \mathrm{deg} 58^{\prime} 50^{\prime \prime}$ 'W in British Columbia on the east bank of Hasler Creek southwest of Chetwynd (figure 1 and 


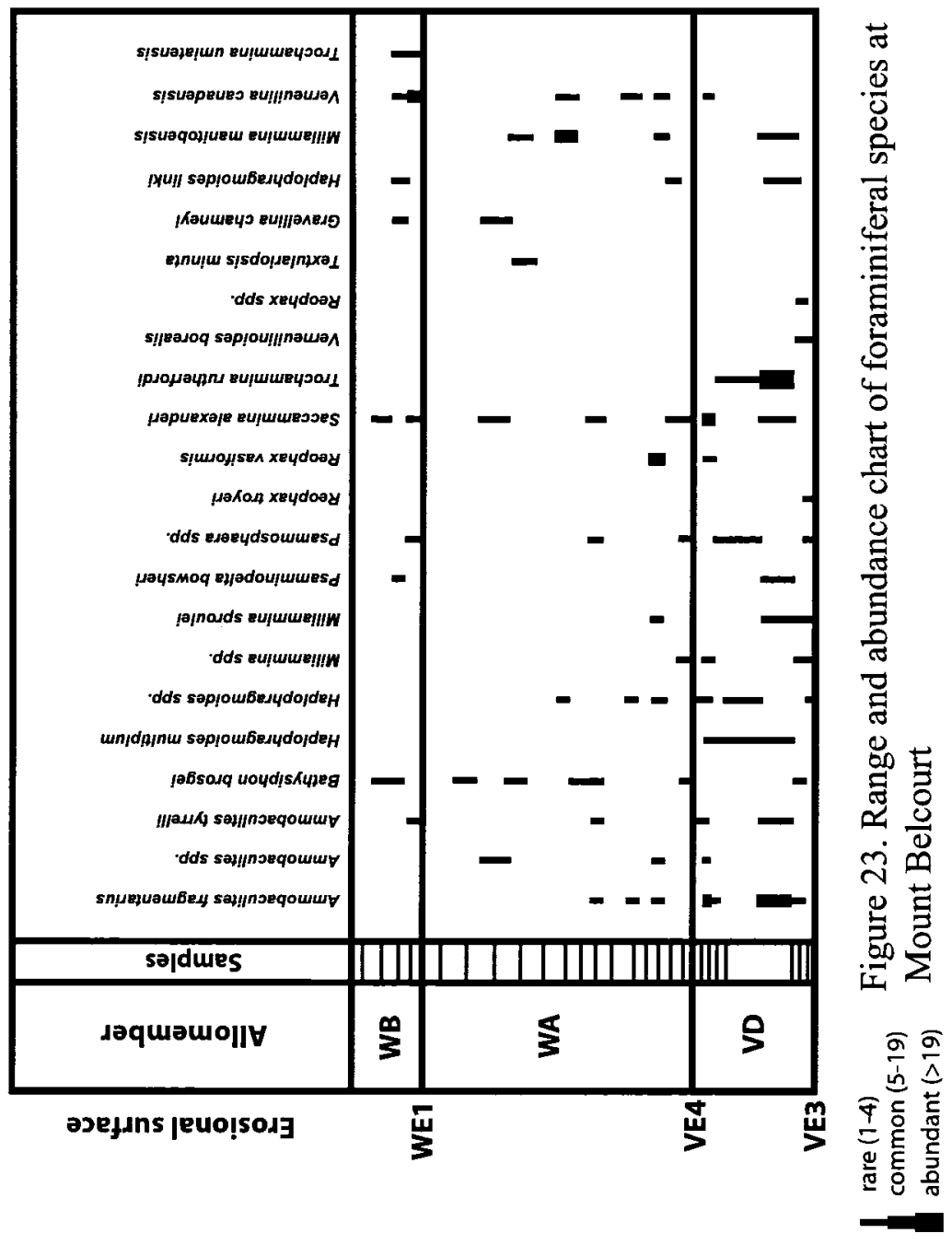


table 1). This outcrop is reached by a service road off Highway 97 that runs south along Hasler Creek.

\section{Lithology:}

The $85 \mathrm{~m}$ thick Hasler Creek section (figure 24) includes strata of allomembers WB and WC (figure 25a). The initial $80 \mathrm{~m}$ contains laterally continuous very fine to fine grained sandstone beds $2-5 \mathrm{~cm}$ thick interbedded with dark grey mudstone (facies III), with sporadic siderite concretions. Sandstone beds often form coarsening upwards sequences with wave rippled tops (figure $25 \mathrm{~b}$ ). Bioturbation is very abundant within the section and is especially visible in the coarser sandstone intervals.

The upper five meters of section coarsens to medium grained sandstone with pebble beds present (facies IV). The basal meter is unconformable and is represented by a coarse to very coarse grained conglomeratic unit that fines upwards to fine grained sandstone. This unit has abundant Skolithos burrows and cross-stratification. The overlying sandstone is well indurated and forms a cliff at the top of the outcrop.

\section{Micropaleontology:}

The Hasler Creek section contains 17 foraminiferal species (figure 26). Despite common bioturbation foraminiferal abundance within the section was low and preservation was poor. No indicator species of the newly established zonation were present to allow assemblage placement. However species present, such as Verneuilina canadensis, Miliammina manitobensis, and Haplophragmoides postis are elements common to the Trochammina umiatensis and Haplophragmium swareni assemblages suggesting placement within these two units. Log correlations (see wireline 


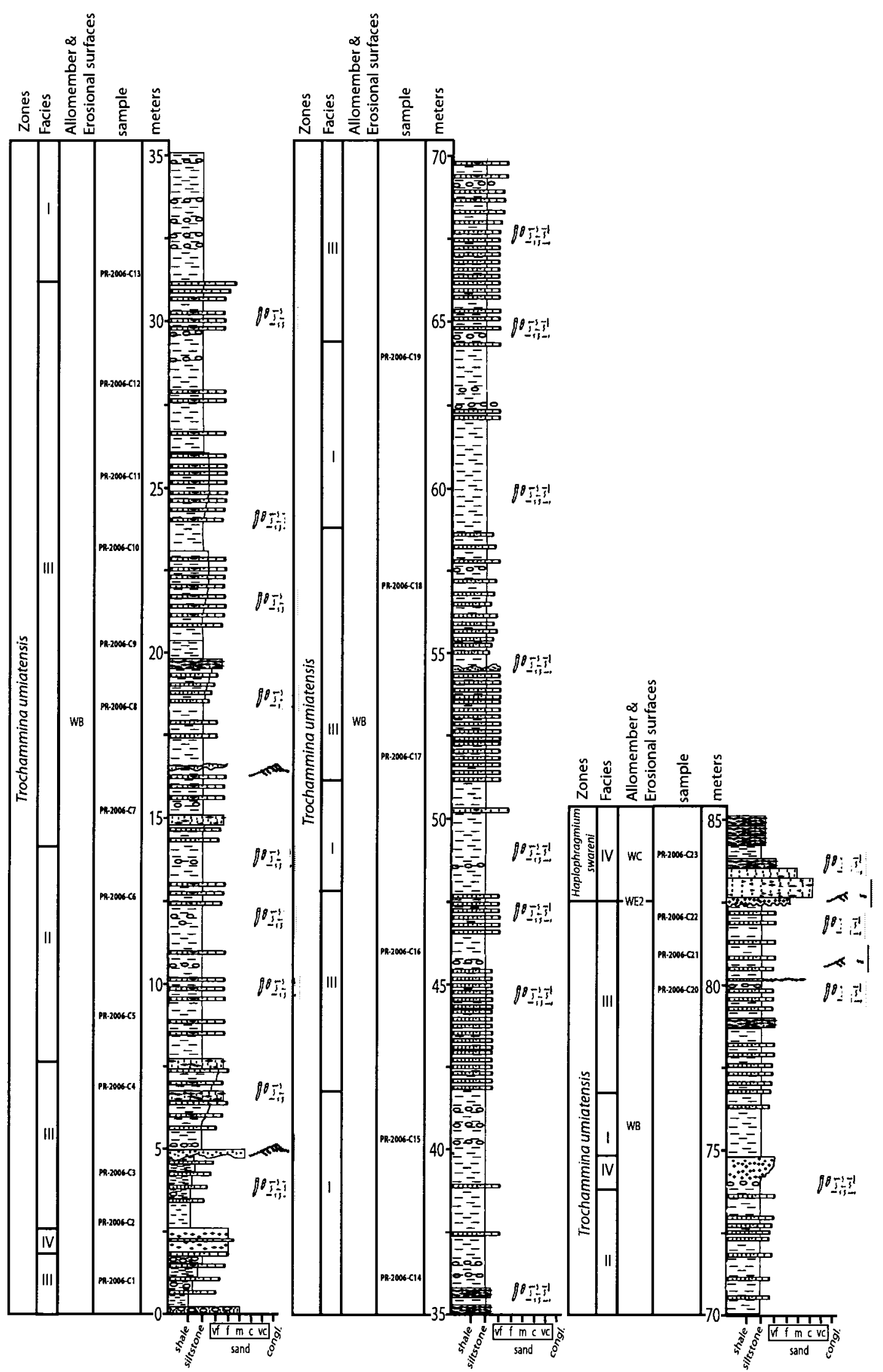

Figure 24. Stratigraphic section of the Hasler Creek outcrop with location of foraminiferal samples, allostratigraphic surfaces, facies and foraminiferal zones (refer to legend: figure 8). 

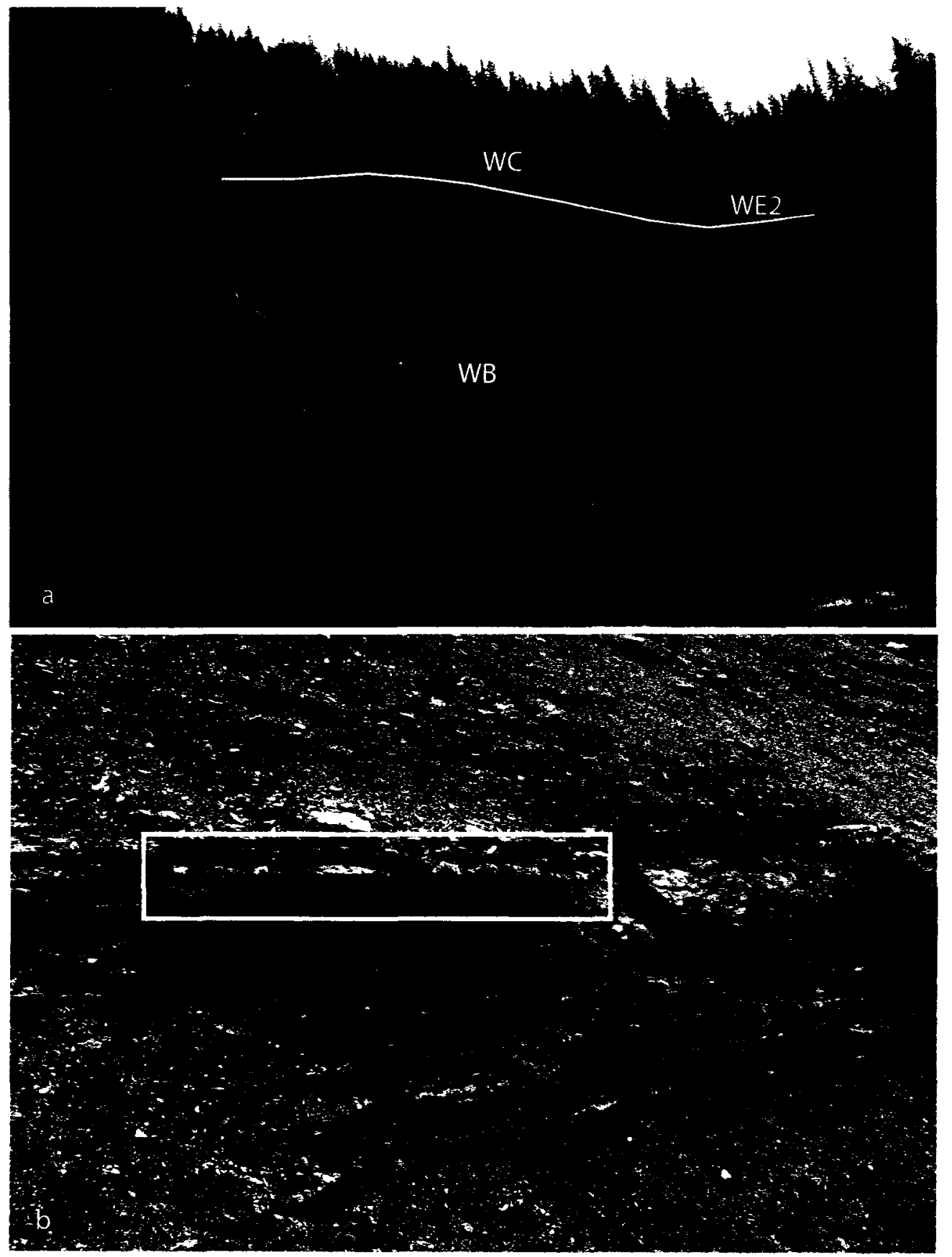

Figure 25. Outcrop photos of Hasler Creek. a) Outcrop exposure of allomembers WB and WC. b) Wave ripples in fine sandstone in allomember WB. 


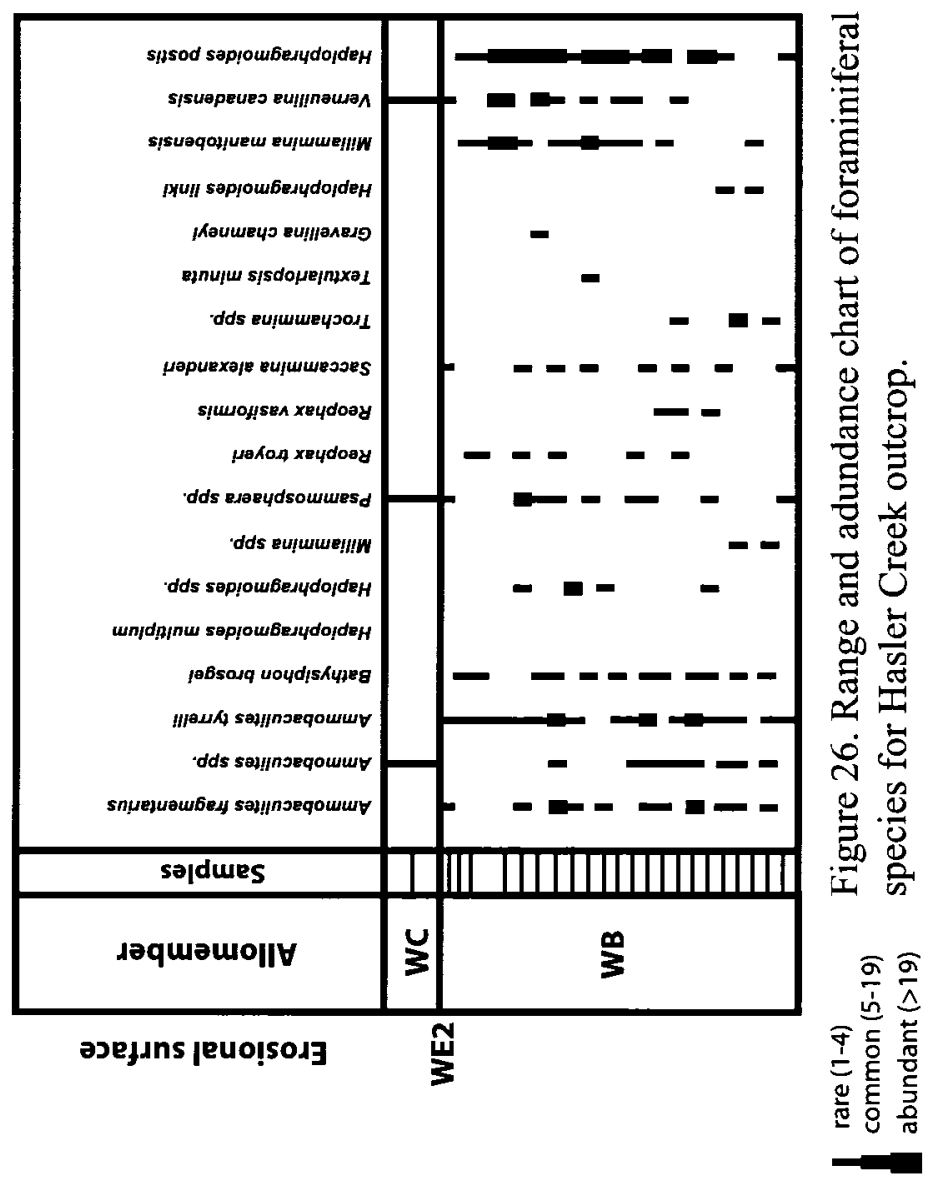


$\log$ correlations) aided to place the outcrop in the WB and WC allomembers, which contain the Trochammina umiatensis and Haplophragmium swareni assemblages. Foraminiferal abundances varied from 2 to 47 specimens per sample (figure 26).

\section{Moberly Lake Road}

The Moberly Lake Road outcrop consists of a number of small road cuts on Highway 29 along Moberly Lake at 55 deg 54'30' - 55 deg 55'30' 'N and $121 \mathrm{deg}$ 55'00' W in British Columbia (figure 1 and table 1). The outcrops lie on the east side of the road just north of Moberly Lake. Dip measurements, where available, varied from 25 degrees. Due to the large length of covered intervals between road cuts the overall thickness might be overestimated. A change to horizontal beds or other structural changes might have lengthened the section.

\section{Lithology:}

The $850 \mathrm{~m}$ Moberly Lake Road outcrop consists of eight small outcrops (figure 27) that make up $60 \mathrm{~m}$ of section; the remaining $790 \mathrm{~m}$ are covered. Despite the unfavourable representation this outcrop was included for two reasons: 1) it represents a long stratigraphic interval from the VE3 surface to the FSU surface (figure 27); and 2) this outcrop forms part of the base for the original foraminiferal subzonation (Sutherland and Stelck, 1972; Koke and Stelck, 1984, 1985; Stelck and Koke, 1987). This outcrop includes the upper Viking, Hasler, Goodrich and Cruiser formations covering the VD, WA, WB, WC, FA and FB allomembers. Starting at the north end of the section (stratigraphically oldest) the lowest two outcrops, a and b, (figure 28 a, b) which are separated by a covered interval of $21 \mathrm{~m}$, consist predominately of dark grey mudstone 


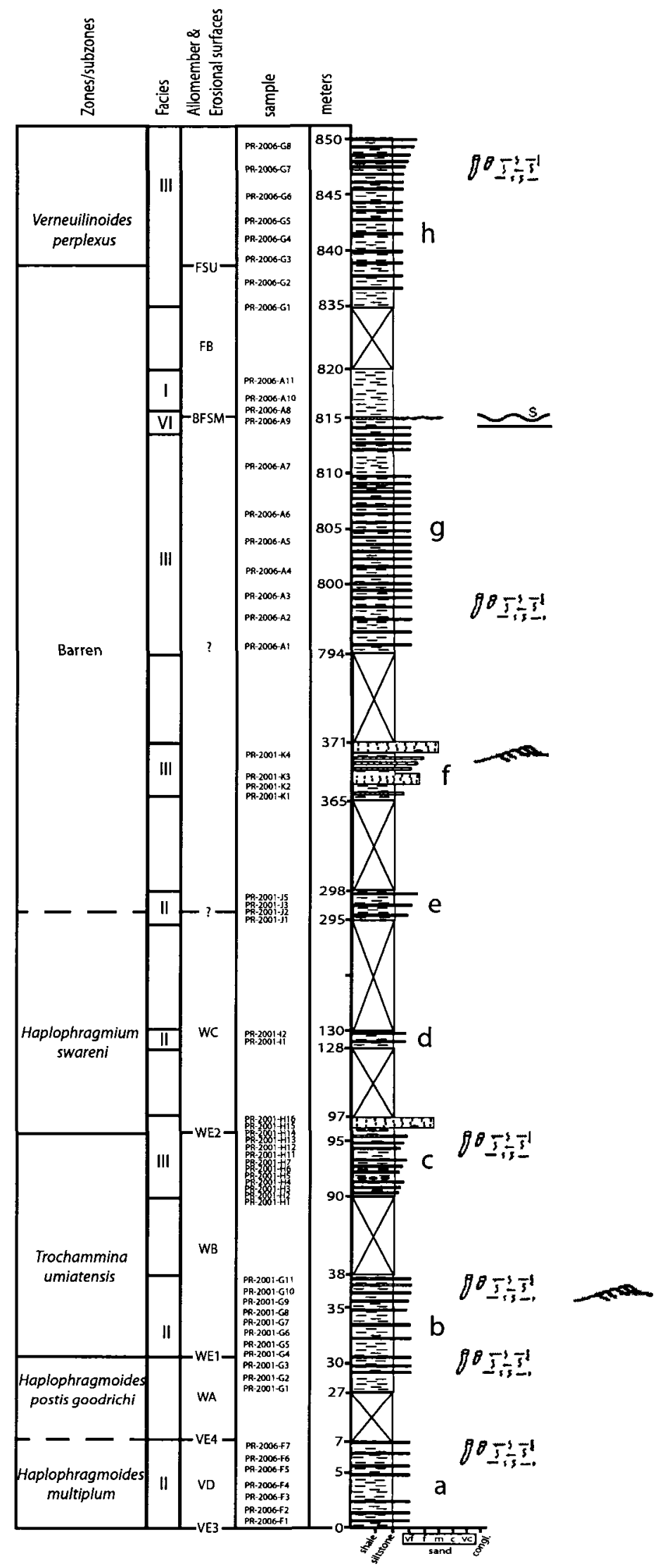

Figure 27. Stratigraphic section of the Moberly Lake Road outcrop with location of foraminiferal samples, allostratigraphic surfaces, facies and foraminiferal zones. Letters refer to different outcrops (refer to legend: figure 8). 

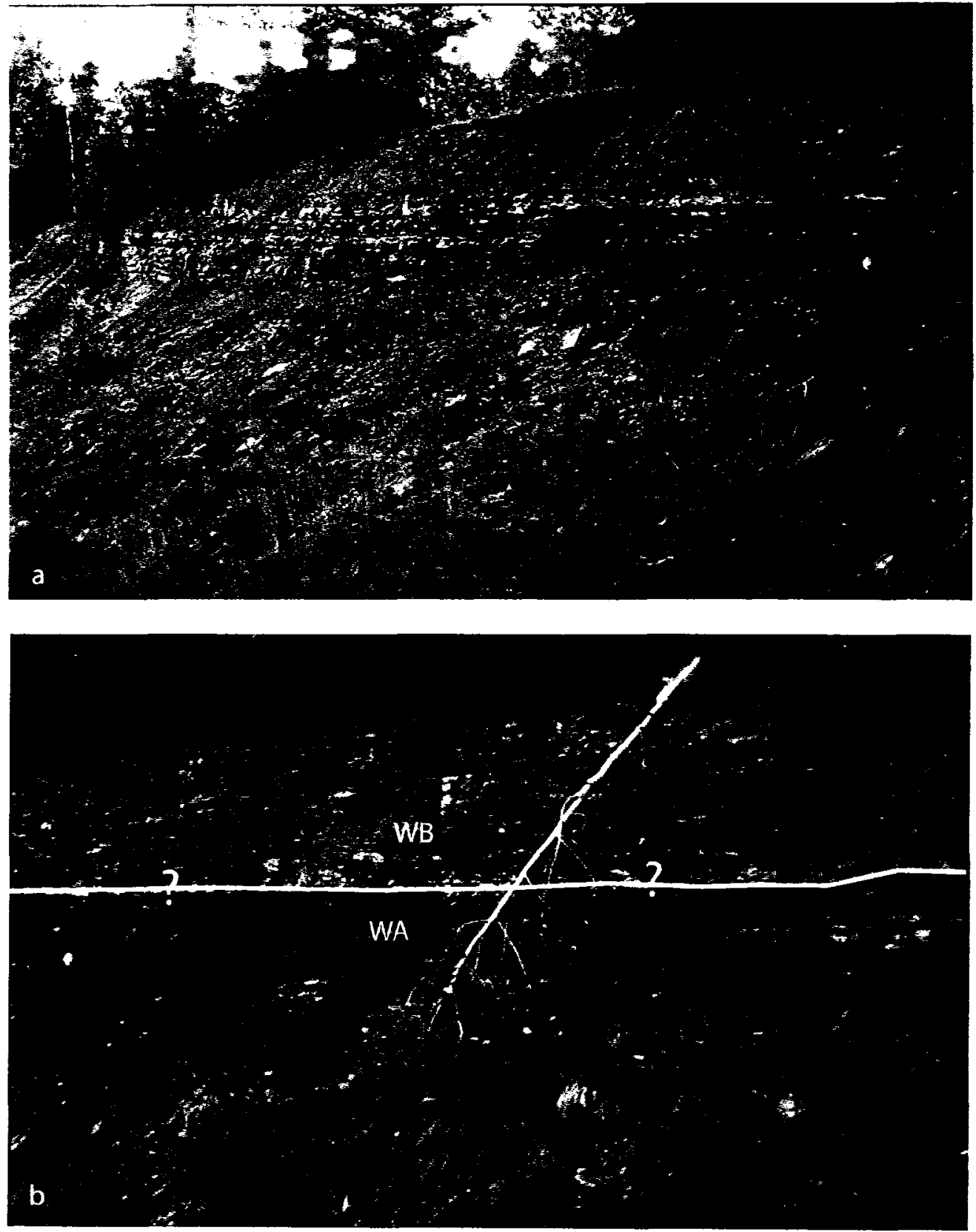

Figure 28. Outcrop photos of the Moberly Lake Road section. a) northern most outcrop ( $a$ in figure 27) representing allomember VD. b) second outcrop (b in figure 27) moving south containing allomembers WA and WB. 
interbedded with $2-5 \mathrm{~cm}$ thick very fine sandstone (facies II). Sandstones are bioturbated with increasing bioturbation upsection and are wave rippled in the upper portion of outcrop b.

Following a covered interval of $56 \mathrm{~m}$, the third outcrop, c, (figure 29 a) consists of ten meters of fine grained $4-20 \mathrm{~cm}$ thick sandstone interbedded with mudstone (facies III). Siderite concretions and bioturbation are abundant within this section. The uppermost meter of the outcrop is mudstone (facies I).

From $97 \mathrm{~m}$ to $365 \mathrm{~m}$ only seven meters of outcrop are exposed (figure 27 ) as two small outcrops; $d$ and e (figure 27). Outcrop $d$ is two meters of mudstone (facies I) and outcrop e is five meters of a black mudstone (facies I) (figure $29 \mathrm{~b}$ ). At $365 \mathrm{~m}$, outcrop $\mathrm{f}$ (figure 27), contains seven meters of very fine to fine grained 5 to $25 \mathrm{~cm}$ thick sandstones with mudstone interbeds (facies III) (figure 30a). Sandstones are hummocky crossstratified (figure 30b), current rippled (figure 31a) and show minor bioturbation.

Outcrops g and h (figure 27) follow a $422 \mathrm{~m}$ covered interval. Outcrops f (figure 31b) and g consist predominantly of very fine to fine grained sandstone with interbedded mudstone (facies III). A conglomeratic lag (facies VI) with chert pebbles and fish scales is present at $815 \mathrm{~m}$ (figure $31 \mathrm{~b}$ ). Gamma Ray readings (figure 32) show a sharp spike just above this lag which is tentatively correlated with the Fish Scales Marker Bed (BFSM). The lag is overlain by mudstone (facies I). Following $15 \mathrm{~m}$ of covered interval the section coarsens upwards to fine grained sandstone (facies III) with common bioturbation.

\section{Micropaleontology:}

The Haplophragmoides multiplum assemblage (VD allomember) is present in outcrop a (figure 27). The assemblage is very diverse containing 20 foraminiferal species 

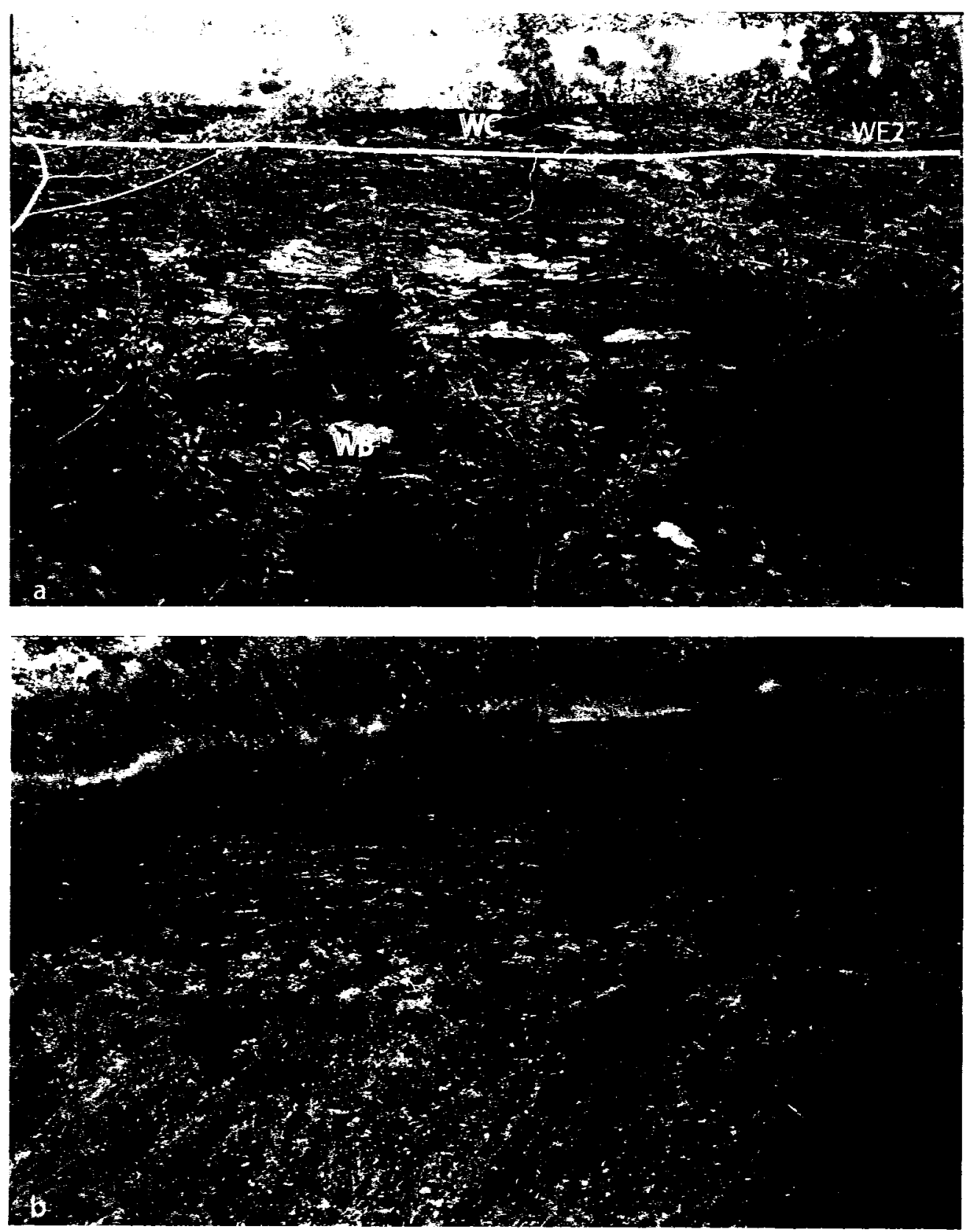

Figure 29. Outcrop photos of the Moberly Lake Road section. a) outcrop c in figure 27; fine sandstone interbedded with siltstone coarsening upwards to medium grained standstone containing allomembers WB and WC. b) Dark fine grained interval at $295 \mathrm{~m}$ (e in figure 27) in allomember WC. 

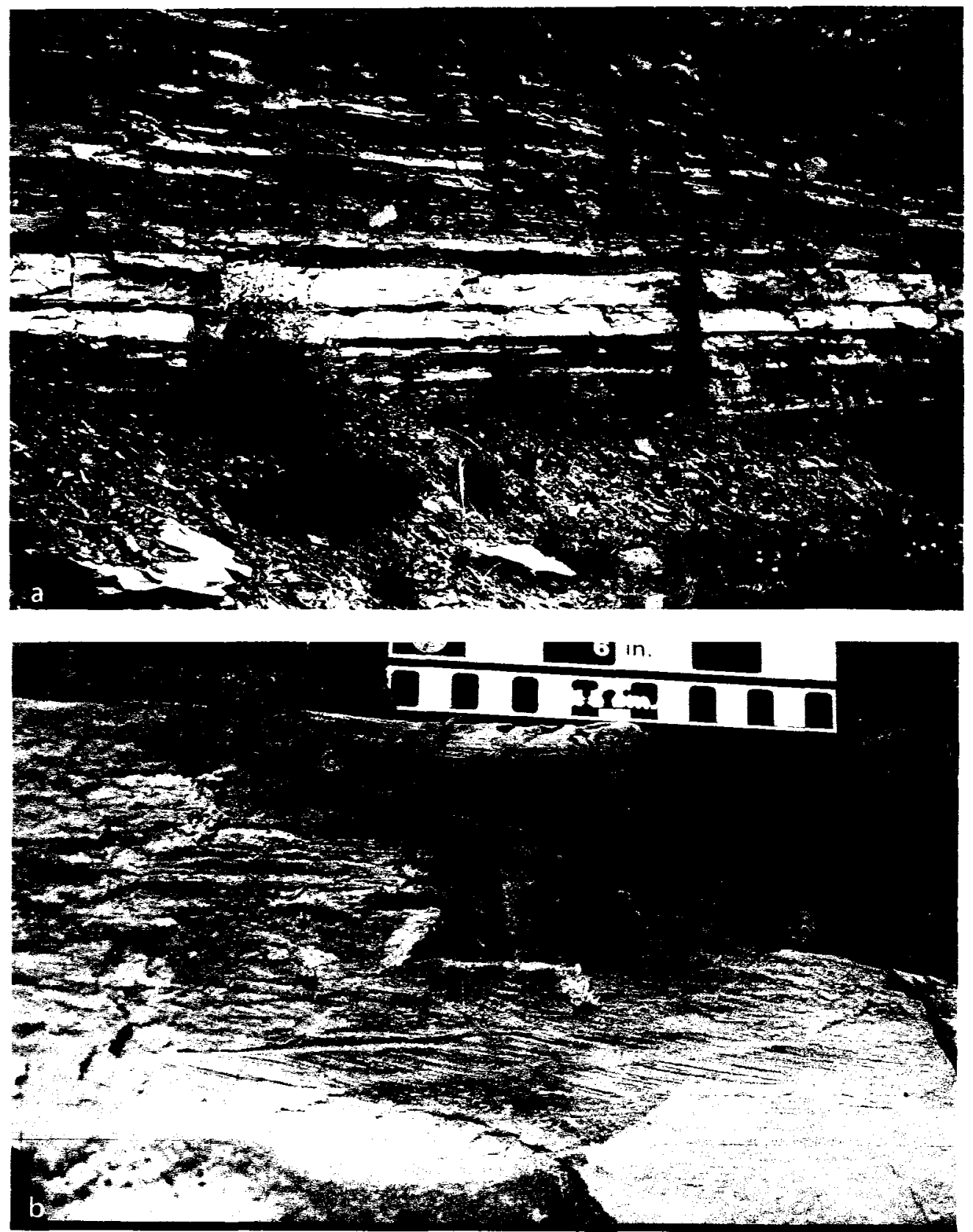

Figure 30. Outcrop photos of the Moberly Lake Road section. a. Outcrop $\mathrm{f}$ in figure 27 showing very fine to fine grained 5 to $25 \mathrm{~cm}$ thick sandstones with mudstone interbeds in allomember FA . b. Hummocky cross-stratification in fine sandstone in allomember FA in outcrop $\mathrm{f}$ of figure 27. 

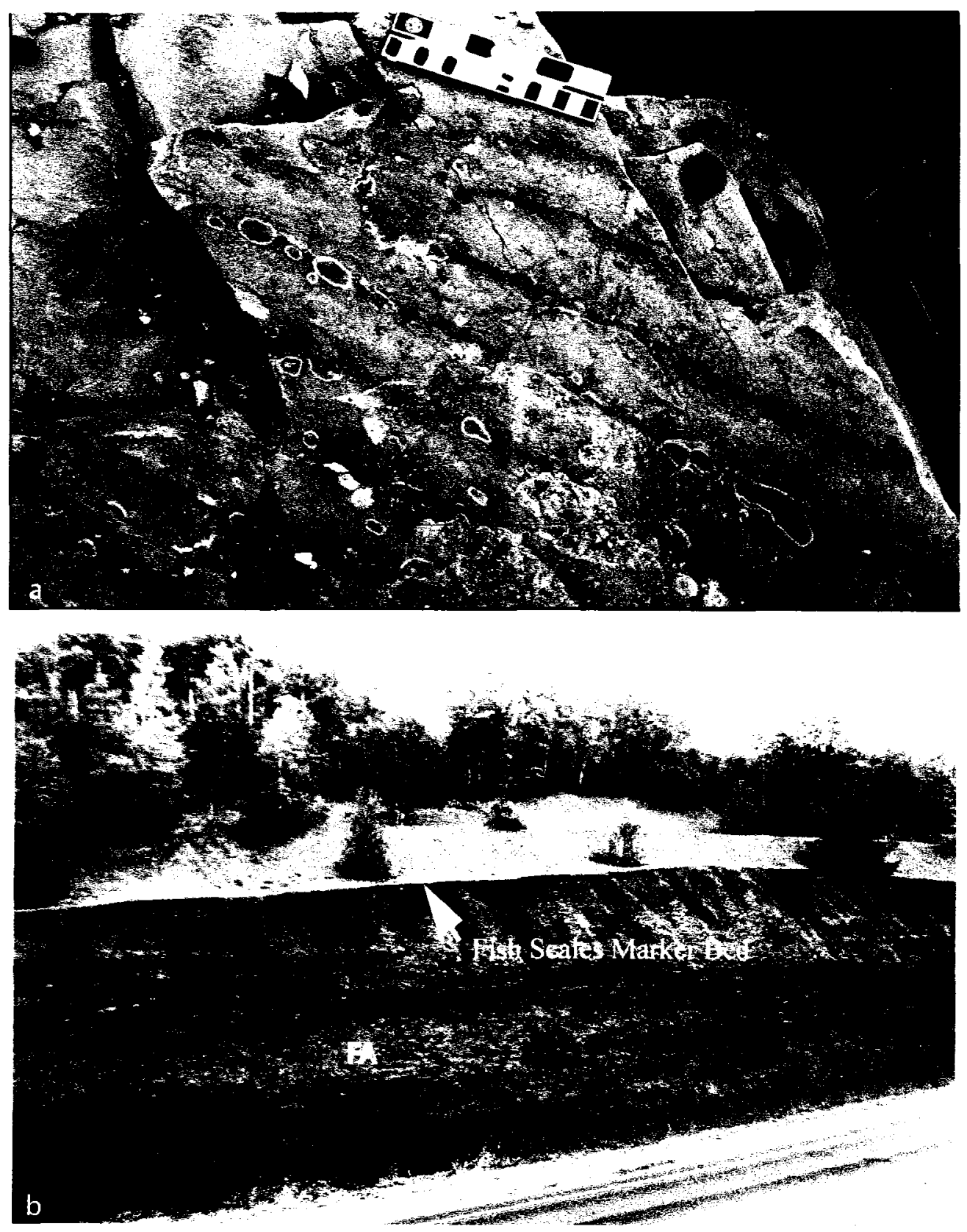

Figure 31. Outcrop photos of the Moberly Lake Road section. a) Asymetrical wave ripples in outcrop f (figure 27) in allomember FA . b) Allomembers FA and FB in outcrop g (figure 27) and Fish Scales Marker Bed (FSMB major flooding surface Roca 2007). 


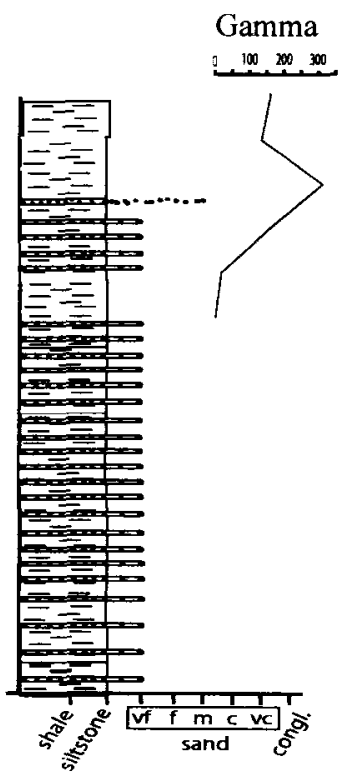

Figure 32. Section of outcrop along Moberly Lake Road containing a highly radioactive pebble bed that is tentatively correlated with the Fish Scale Marker Bed or FSMB in Roca (2007). 
with abundances ranging from 17 to 102 specimens per sample. Three meters of the Haplophragmoides postis goodrichi assemblage is present in the lower portion of outcrop b (figure 27). This short interval contains the species Trochammina rutherfordi, a species that occurs in both the Haplophragmoides multiplum and Haplophragmoides postis goodrichi assemblages. Neither indicator species, Haplophragmoides multiplum or Haplophragmoides postis goodrichi are present (figure 33) however wireline logs (see wireline log correlation) place this interval in the WA allomember (Haplophragmoides postis goodrichi assemblage). This interval contains 12 foraminiferal species with abundances ranging from 28 to 82 specimens per sample (figure 33 ).

The Trochammina umiatensis assemblage (allomember WB) starts at $30 \mathrm{~m}$ and continues to $95 \mathrm{~m}$ (figure 27 outcrops b \& c). The assemblage contains 18 foraminiferal species with abundances ranging from 4 to 84 specimens per sample (figure 33 ). The Haplophragmium swareni assemblage (allomember WC) is present in outcrops $\mathrm{c}$ and $\mathrm{d}$ in the interval from the sandstone at $95 \mathrm{~m}$ to the small black mudstone at $295 \mathrm{~m}$ (figure 27). The assemblage contains 19 foraminiferal species with abundances ranging from 3 to 14 specimens per sample (figure 33).

Foraminiferal samples from $236 \mathrm{~m}$ to $815 \mathrm{~m}$ (figure 27 ) were mostly barren. Three samples did contain a few foraminifera but specimens belonged to common long ranging taxa making placement impossible (figure 33). Above the Fish Scales Marker Bed (BFSM), the FB allomember is barren (figure 27). The remaining ten meters of section (outcrop h) represents the Gaudryina irenensis Subzone of the Verneuilinoides perplexus Zone. 


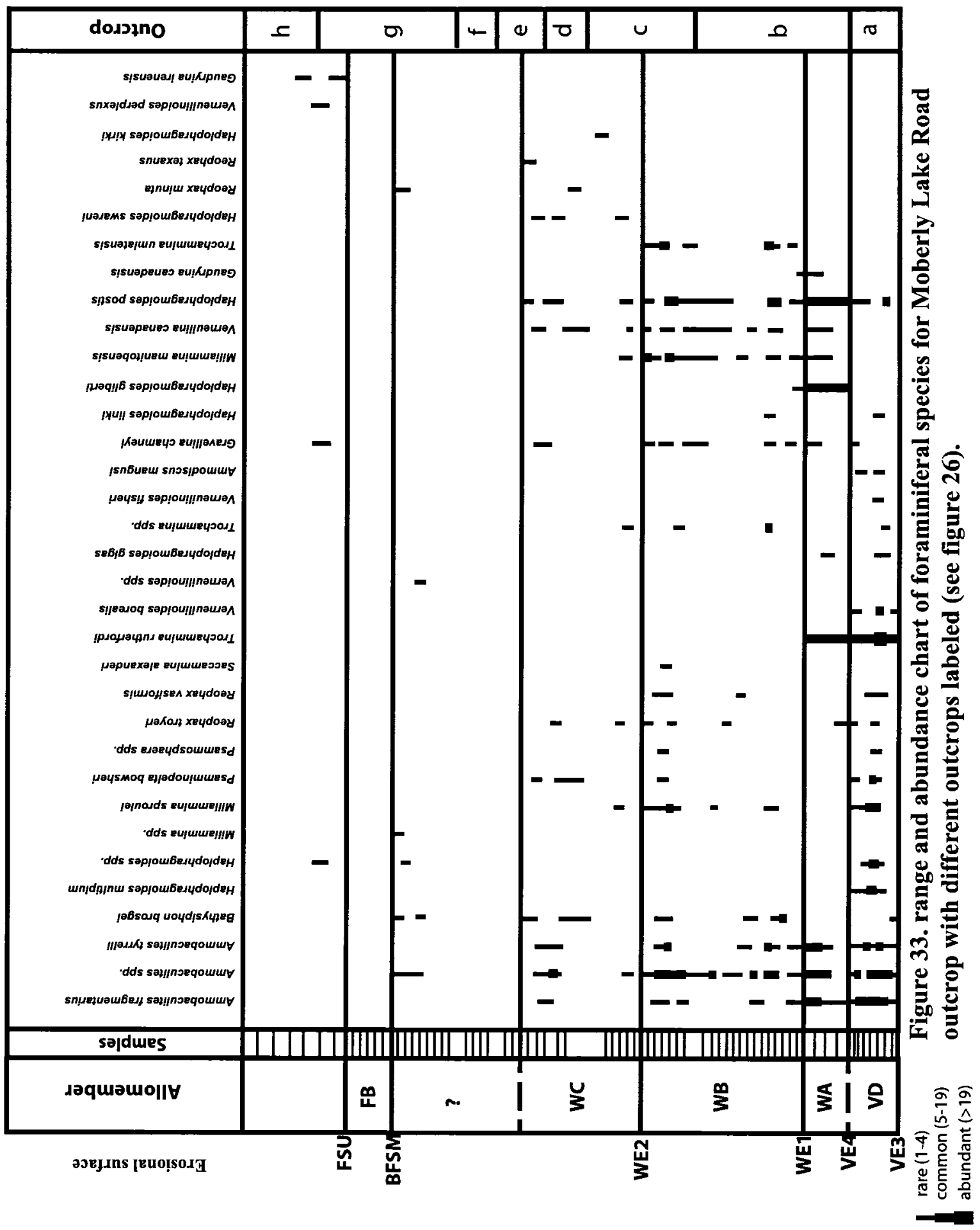




\section{Halfway River}

The outcrop at Halfway River sits on the east bank of the river just north of Highway 29 at $56 \mathrm{deg} 13^{\prime} 45^{\prime}$ ' $\mathrm{N}$ and $121 \mathrm{deg} 29^{\prime} 00^{\prime}$ ' W in British Columbia (figure 1 and table 1). The outcrop is situated north of the bridge on Highway 29 were it crosses the Halfway River.

\section{Lithology:}

The Halfway River outcrop is a $15 \mathrm{~m}$ section (figure 34) that consists of 5 to 15 $\mathrm{cm}$ thick very fine to fine grained sandstone with interbedded mudstone (facies III) with abundant siderite nodules (Figure 35). At five meters minor bioturbation is present and symmetrical wave ripples are present in a $12 \mathrm{~cm}$ fine to medium grained sandstone. From $10 \mathrm{~m}$ to $12 \mathrm{~m}$ the section consists of fine grained sandstone (facies IV) with a $14 \mathrm{~cm}$ coarse grained sandstone within it followed by three meters of dark grey mudstone (facies I).

\section{Micropaleontology:}

The Haplophragmoides multiplum assemblage is present in the basal five meters of section (allomember VD) and ends at a fine grained sandstone bed that is $12 \mathrm{~cm}$ thick (figure 34). This assemblage contains 18 foraminiferal species and has foraminiferal abundances from 14 to 53 specimens per sample (figure 36). The Haplophragmoides postis goodrichi assemblage occurs in the final ten meters of the section (allomember WA) and contains 22 foraminiferal species and abundances from 29 to 184 specimens per sample (figure 36). This outcrop contains the most diverse Haplophragmoides postis goodrichi assemblage with the study with Ammobaculites fragmentarius, Ammobaculites 


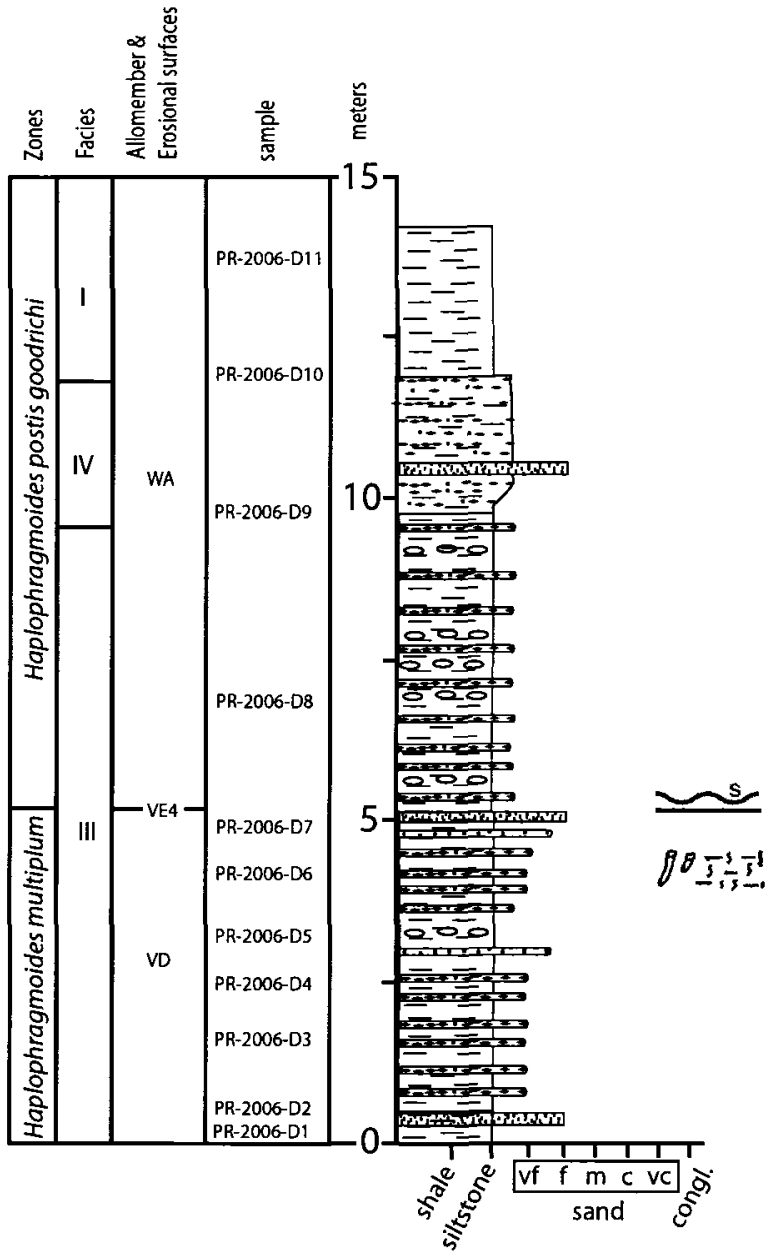

Figure 34. Stratigraphic section of the Halfway river outcrop with location of foraminiferal samples, allostratigraphic

surfaces, facies and foraminiferal zones (refer to legend: figure 8). 


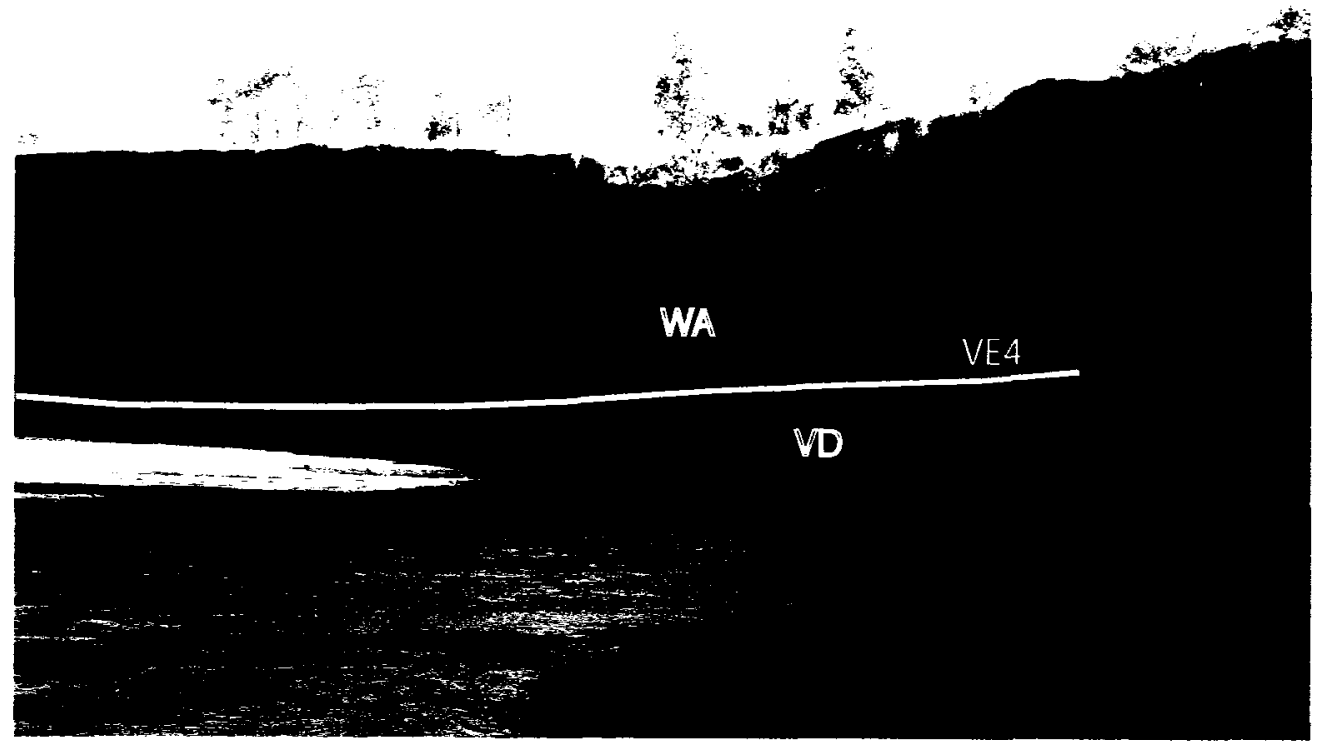

Figure 35. Outcrop of the Halfway River section containing allomembers VD and WA featuring mudstone with interbedded very fine to fine grained sandstone. 


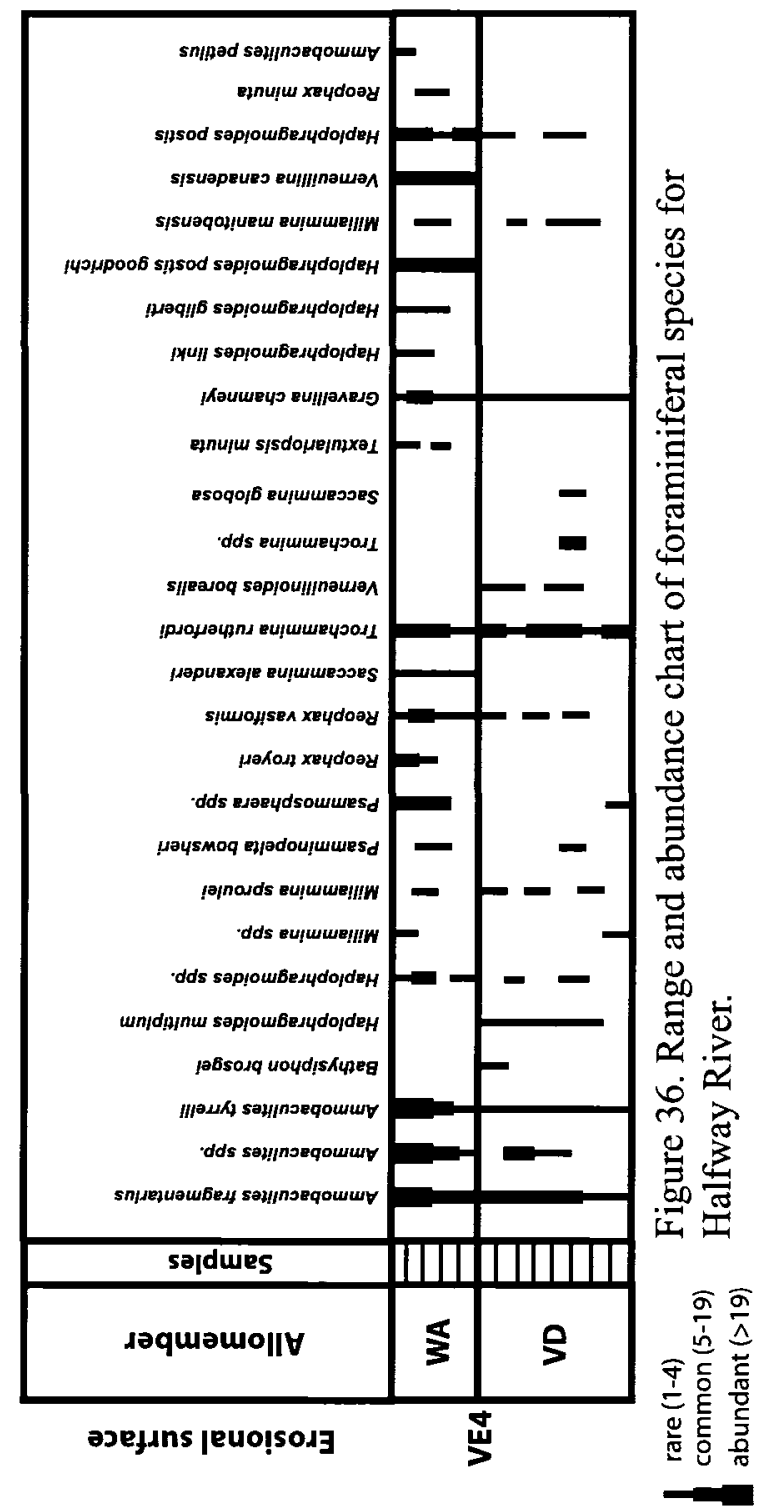


tyrrelli, Psammosphaera spp., Haplophragmoides spp., Reophax vasiformis, Reophax troyeri, Trochammina rutherfordi, Gravellina chamneyi, Haplophragmoides postis goodrichi, Verneuilina canadensis, and Haplophragmoides postis all being common.

\section{Cores}

The allostratigraphic framework by Roca (2007), which is the basis for my correlations, is mainly based on subsurface stratigraphic correlations. Therefore three cores were sampled for foraminifera that are located in Roca's southern study area (figure 1) in an attempt to: a) extend biostratigraphic correlations from outcrops into the subsurface; and b) test the lower Viking allomembers below surface VE3 for foraminiferal content that is represented in one of the cores. Unfortunately, samples were either barren or contained low foraminiferal counts that were poorly preserved. For documentation purpose results are included.

\section{Core 10-33-34-5W5}

\section{Lithology:}

Core 10-33-34-5W5 is $52 \mathrm{~m}$ long and comprises an interval from the VE4 to the BFSM surfaces (figure 37). The lowest $12 \mathrm{~m}$ of this section consists of medium to coarse grained cross-stratified sandstone with minor mudstone interbeds (facies I, II and IV). Multiple pebble beds are found within the cross-stratified sandstone as well as minor bioturbation. Mudstone intervals contain abundant pyrite. A finer interval of mudstone with scattered fine to medium sandstone (facies I and II) is present from $12 \mathrm{~m}$ to the BFSM erosional surface at $44 \mathrm{~m}$ (figure 37). Fish scales are present throughout this interval and become increasingly abundant higher in the section. A coarsening upwards 


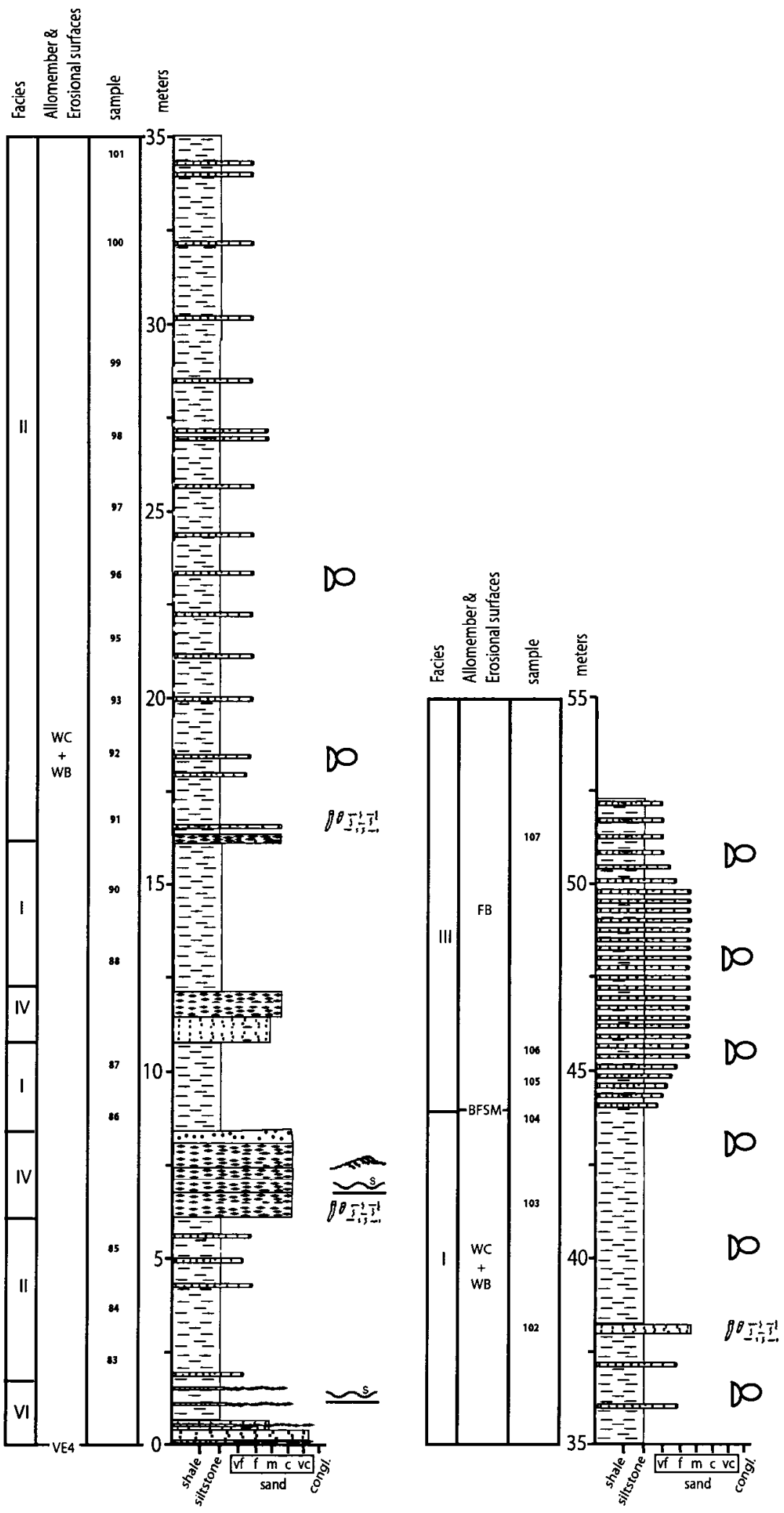

Figure 37. Stratigraphic section of the 10-33-34-5W5 core with location of foraminiferal samples, allostratigraphic surfaces and facies (refer to legend: figure 8). No foraminiferal zones are recognized in this core. 
and then fining upwards cycle is represented from $44 \mathrm{~m}$ to the top of the core. This very fine to medium grained sandstone interval with mudstone interbeds (facies II) contains abundant fish scales and wave ripples.

\section{Micropaleontology:}

Of the 23 samples obtained from the 10-33-34-5W5 core only two yielded rare foraminifera (figure 38). Due to poor preservation and long biostratigraphic ranges of the species present, no zone was assigned. The taxa Ammobaculites, Trochammina, Miliammina, Gravellina chamneyi and Haplophragmoides were identified.

\section{Core 13-11-41-26W4}

\section{Lithology:}

Core 13-11-41-26W4 is $23 \mathrm{~m}$ long and ranges from the VE3 surface to the WA allomember (figure 39). The basal four meters of core is a mudstone capped by a $20 \mathrm{~cm}$ coarse sandstone bed. This interval contains four pebble beds, two of which represent erosional surfaces (Figure 39). The remaining $19 \mathrm{~m}$ of core is a mudstone (facies I) with a few $2-4 \mathrm{~cm}$ thick sandstone beds.

\section{Micropaleontology:}

Due to poor preservation and long biostratigraphic ranges of the species present, no assemblage was assigned between the VE3 and VE4 surfaces. The Trochammina umiatensis assemblage is present above the VE4 surface in the WC allomember and also contains the species Verneuilina canadensis, Miliammina manitobensis, Ammobaculites fragmentarius and Ammobaculites tyrrelli (figure 38). 


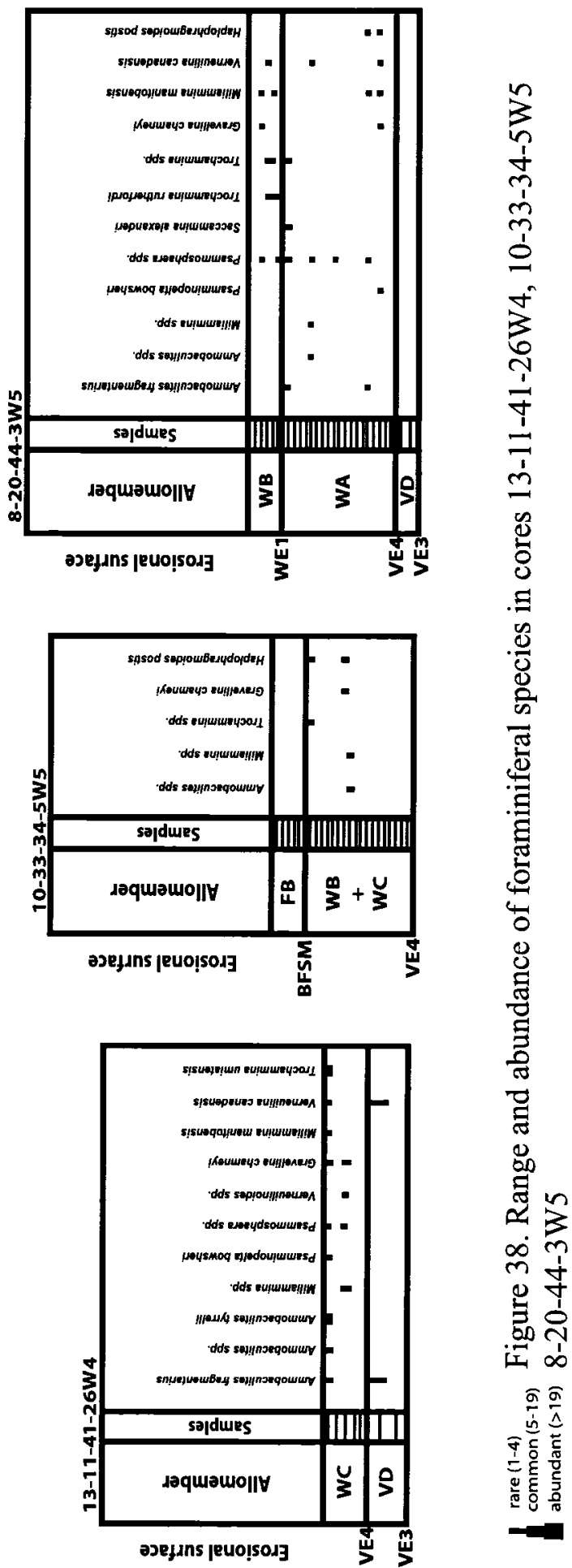




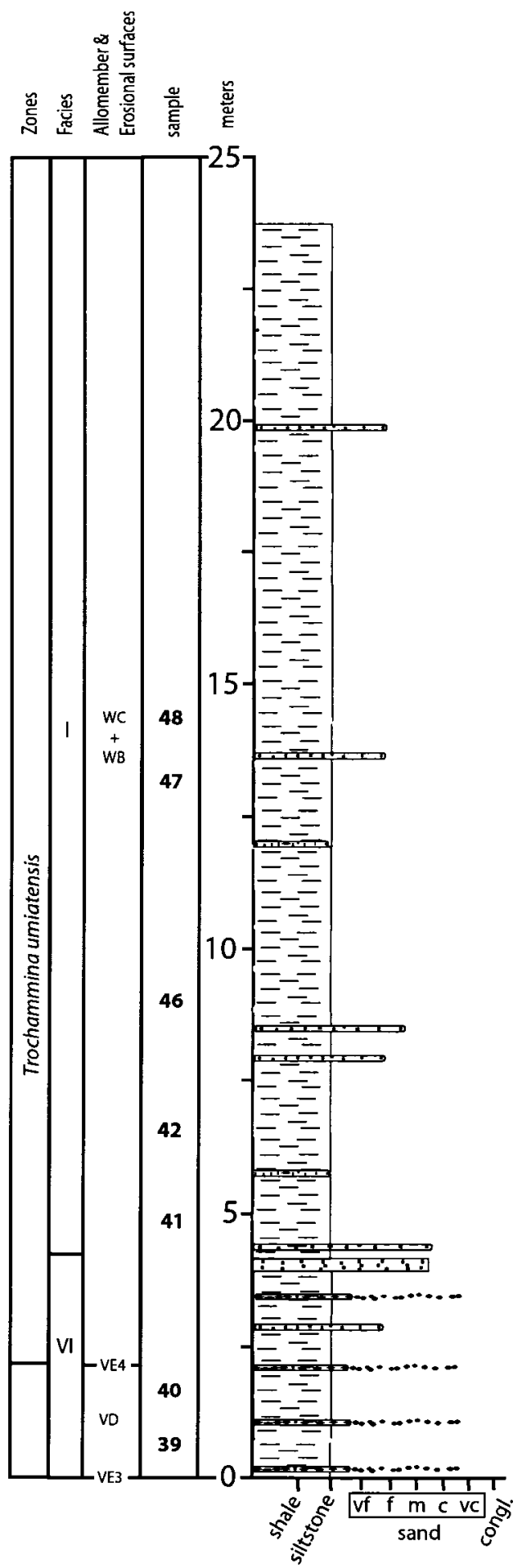

Figure 39. Stratigraphic section of the 13-11-41-26W4 core with location of foraminiferal samples, allostratigraphic surfaces (Roca, 2007), facies and foraminiferal zones (refer to legend: figure 8). 


\section{Core 8-20-44-3W5}

\section{Lithology:}

Core 8-20-44-3W5 covers $58 \mathrm{~m}$ representing strata from the VE3 surface to the WB allomember (figure 40). The lower $25 \mathrm{~m}$ is a medium grained sandstone (facies IV) with three pebble beds at the top, containing the VE3 and VE4 surfaces (fig 40). A mudstone containing very fine to fine wave rippled sandstones ( facies I and II) persist from $25 \mathrm{~m}$ to $49 \mathrm{~m}$. At $49 \mathrm{~m}$ a four meter coarsening upwards cycle begins that ends in a $45 \mathrm{~cm}$ medium sand bed with a pebble bed on top (facies III and VI). The remaining five meters of section becomes a finer grained mudstone (facies II).

\section{Micropaleontology:}

Of the 26 samples from the core 17 were barren of foraminifera. Due to poor preservation and long biostratigraphic ranges of the species present, no assemblage was assigned. The common species Ammobaculites fragmentarius, Haplophragmoides postis, Miliammina manitobensis and Verneuilina canadensis were present. Foraminiferal abundance and biostratigraphic ranges are shown in figure 38 .

\section{Wireline log correlations}

The shallow marine rocks of the Albian-Cenomanian strata were deposited during numerous transgressive-regressive events and hence the stratigraphic succession is punctuated by widely recognizable marine transgressive or flooding surfaces which can be readily identified and correlated in outcrop and subsurface. Because allostratigraphic 


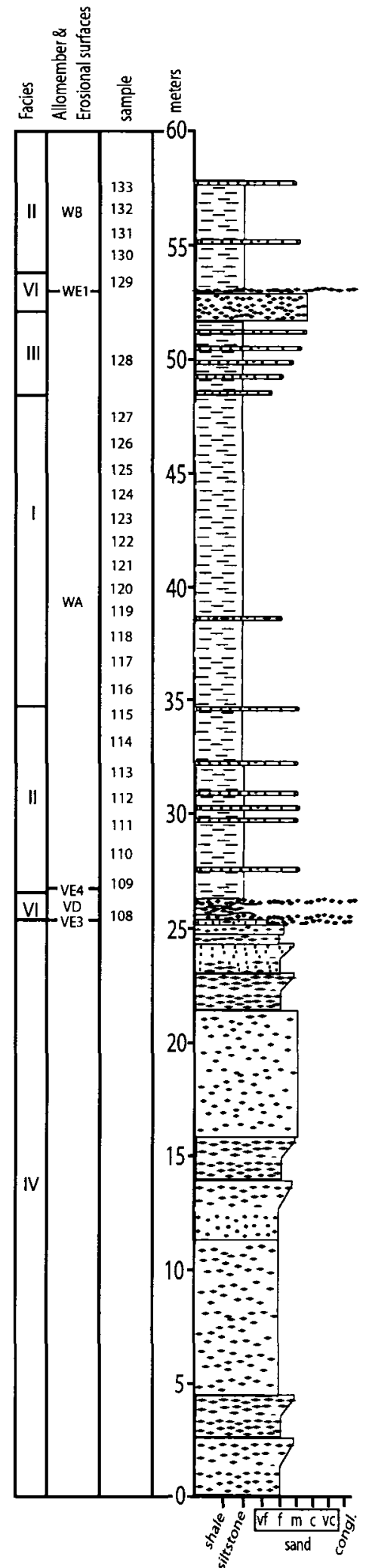

Figure 40. Stratigraphic section of the 8-20-44-3W5 core with location of foraminiferal samples, allostratigraphic surfaces (Roca, 2007) and facies (refer to legend: figure 8). no foraminiferal zones were identified. 
units are defined on the basis of mappable surfaces and are independent of the lithology between the bounding surfaces, an allostratigraphic approach is particularly well-suited to rock units that undergo major lateral variation in facies.

An initial allostratigraphic division of the Viking Formation was presented by Boreen and Walker (1991), who recognized numerous regionally traceable erosional surfaces on which Zhang (2006) and Roca (2007) have built their comprehensive allostratigraphic framework for western Alberta. The purpose of wireline log correlations of this study is to provide an extension of the allostratigraphic framework from western Alberta presented by Zhang (2006) and Roca (2007) to northeastern British Columbia in order to integrate the most western outcrops studied here. Until recently, the lack of a regional stratigraphic framework has made it difficult to relate extended, fine-grained strata of the Rocky Mountain foredeep to coeval rocks in other parts of the basin. The allostratigraphic framework presented by Zhang (2006) and Roca (2007) and extended in this study, allow for detailed correlation of individual depositional units in the subsurface and into outcrop. Such a framework is an essential prerequisite to a workable biostratigraphic framework and a comprehensive paleoenvironmental interpretation. It has to be pointed out that the number of wells that preserve the study interval is reduced in the British Columbia area. This results in large distances between wells giving in turn less confidence to correlations.

Figure 41 uses the complete reference section at Deadhorse Meadows and correlates its flooding surfaces to the nearest well log at 11-3-62-12-12W6 providing a reference for gamma ray and resistivity responses as proposed by Roca (2007). A NWSE and E-W cross-section is presented here (figure 42) that utilizes the erosional surfaces of Roca (2007) and Zhang (2006). The NW-SE cross-section (figure 43) starts just north 


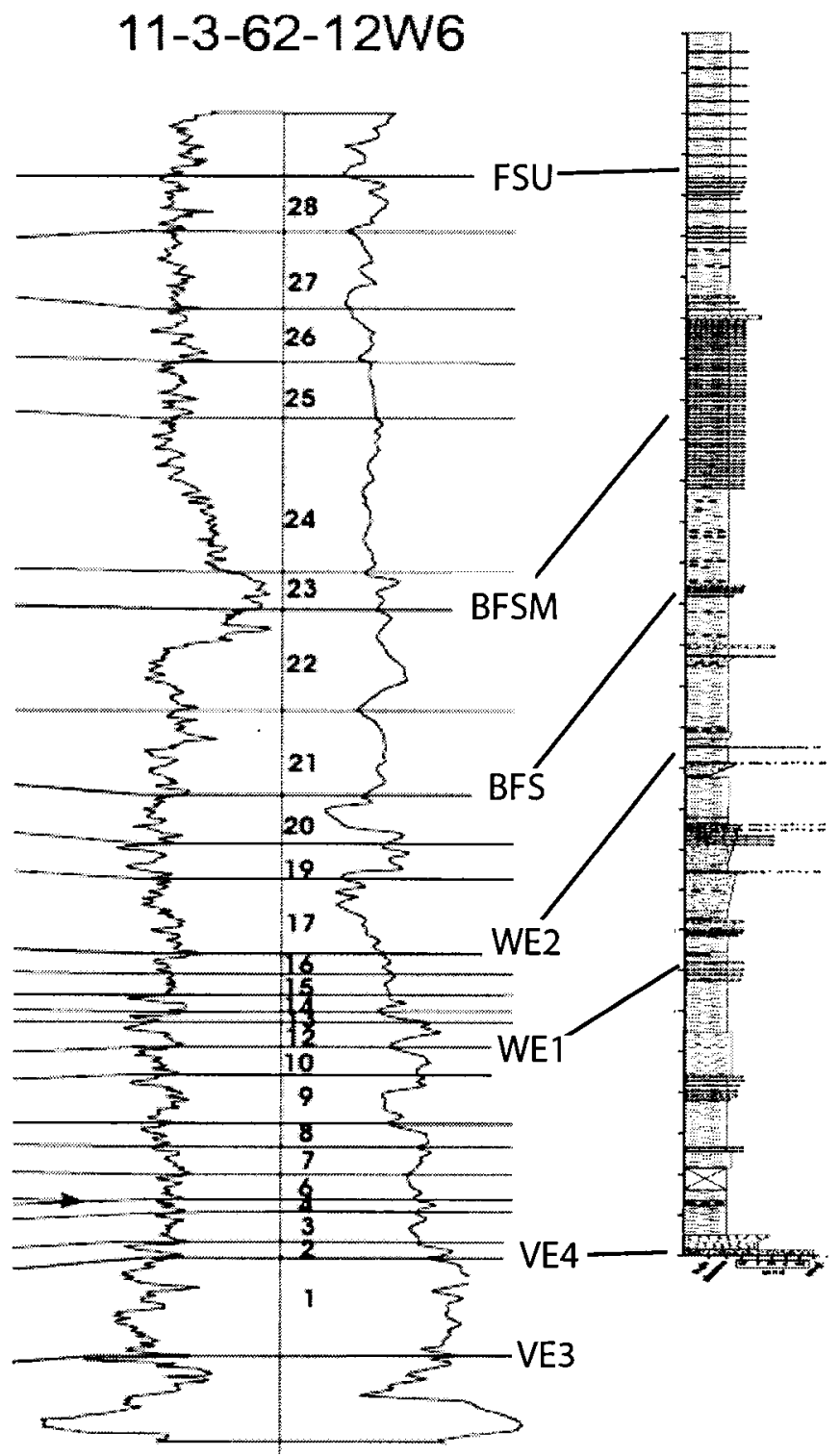

Figure 41. Allostratigraphic surfaces in the Deadhorse Meadows outcrop and well 11-3-62-12W6 (left curve is gamma ray log and right curve is resistivity) showing correlation of surfaces from outcrop into the subsurface (after Roca, 2007). 


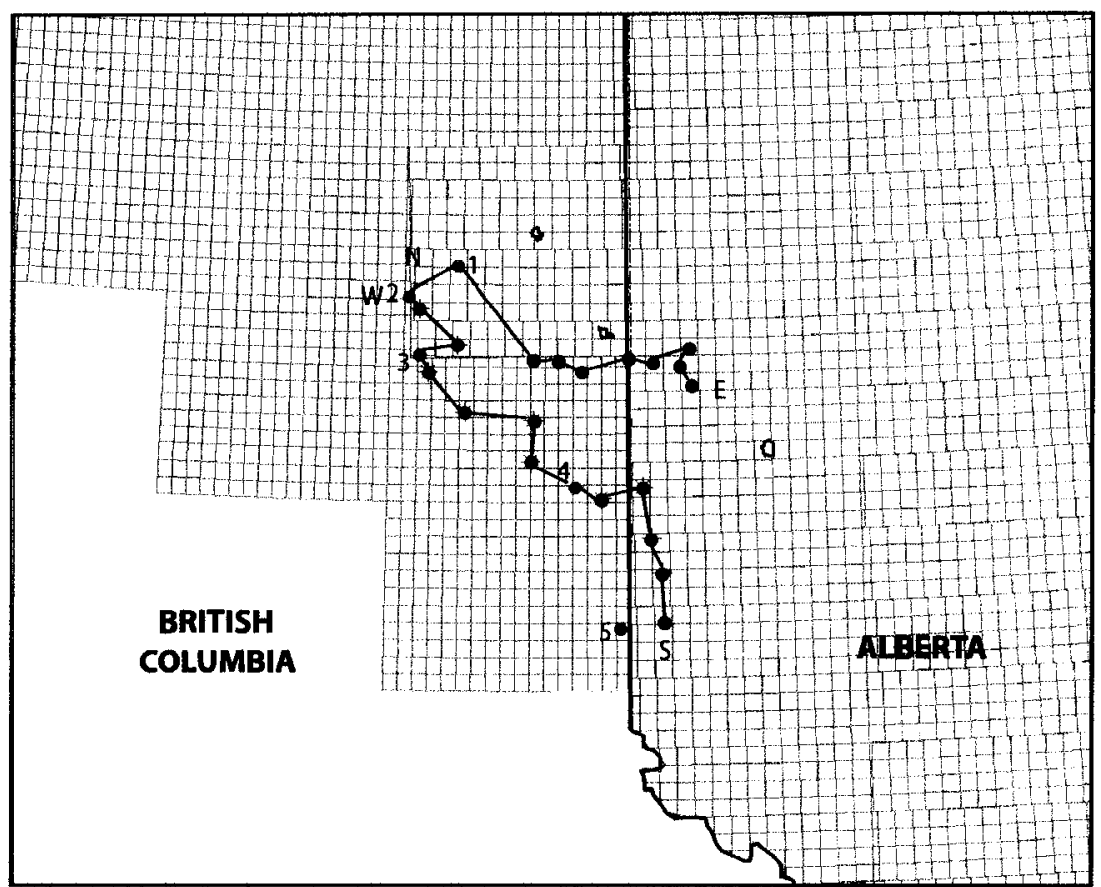

Figure 42. Black dots are wells used to create the NW-SE (blue line) and the east-west (green line) cross-sections. Red dots are outcrops from this study; 1: Halfway River, 2: Moberly Lake Road, 3: Hasler Creek, 4: Mount Belcourt, 5: Deadhorse Meadows. 


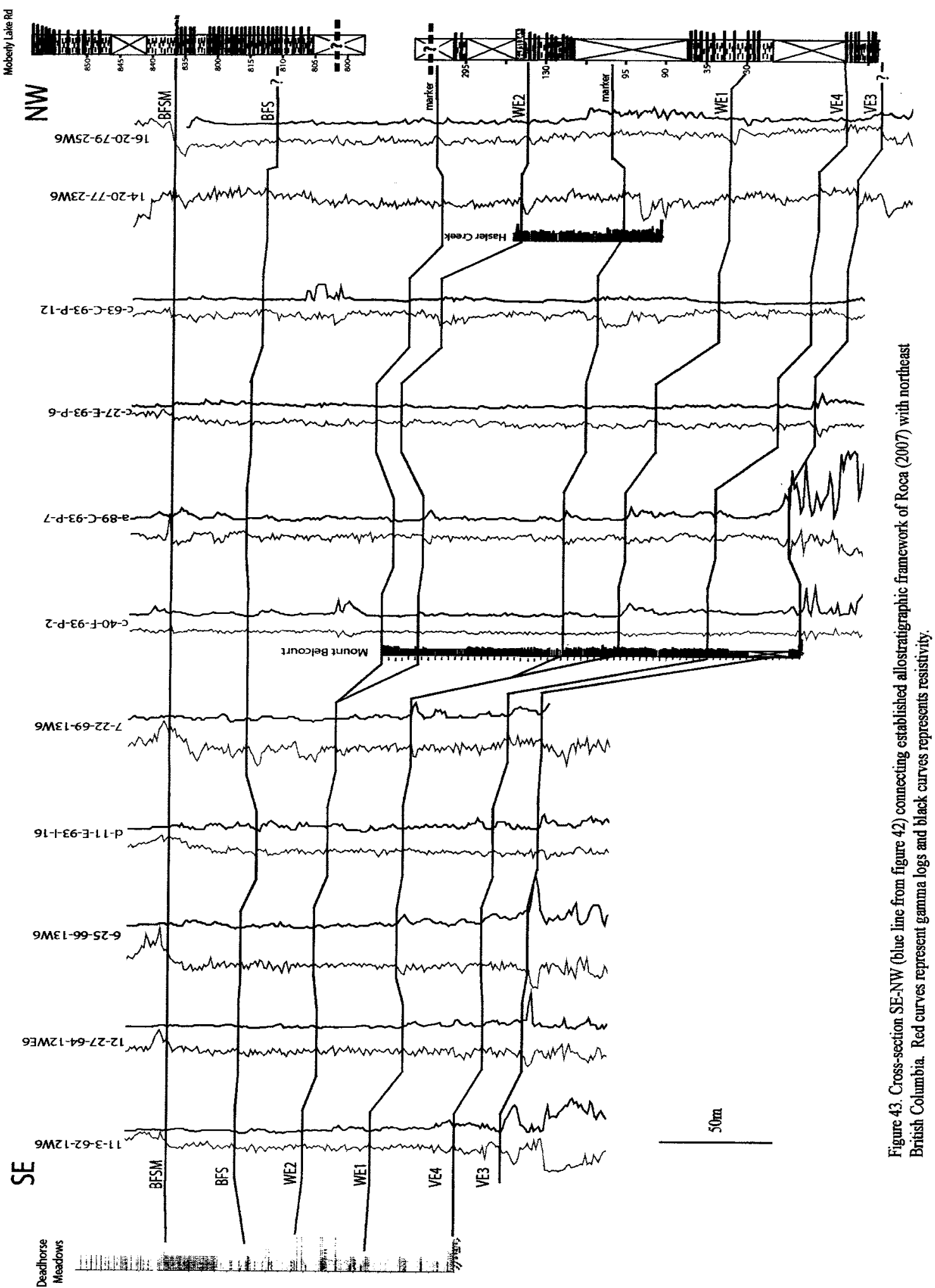

Reproduced with permission of the copyright owner. Further reproduction prohibited without permission. 
of the Deadhorse Meadows outcrop at well 11-3-62-12W6, part of Zhang's (2006) study, and heads northwest into British Columbia to the Moberly Lake Road outcrop. The E-W cross-section (figure 44) also starts in Zhang's (2006) framework at well 6-3-76-13W6 and moves west to the Moberly Lake Road outcrop.

The very distinct gamma-ray kick of the Fish Scale Marker Bed, widely recognized in the entire WCSB, has been used as a datum and cross-sections have been flattened on this surface. On gamma-ray curves flooding surfaces appear as a distinct increase in gamma radiation, and on resistivity curves as a decrease in electrical resistance values.

Broadly speaking, the VD, WA, WB, WC, FA and FB allomembers in British Columbia form a wedge that is thickest in the northwest and gradually thins eastward and southward to the Alberta-British Columbia border (figures 43 and 44). In western Alberta Roca (2007) and Zhang (2006) shows similar gradual thinning of strata to the south and east. On a regional scale Leckie et al. (1994) show a similar wedge formed by the Colorado Group that is thickest in the north and west and thins south and east throughout Alberta.

Log correlations in the British Columbia portion of this study support the micropaleontological framework for the Halfway River, Hasler Creek and Mount Belcourt outcrops. Erosional surfaces from nearby log correlations coincide with foraminiferal assemblage changes from these outcrops. In addition, allomember stratigraphy is in agreement with the sequence of foraminiferal zones (figures 43 and 44).

The Moberly Lake Road section, however, presents problems. Allostratigraphic correlations of the16-20-79-25W6 (Hudson Bay et al. Moberly) well indicate a thickness of $310 \mathrm{~m}$, whereas the total thickness of the Moberly Lake Road outcrops, only five 


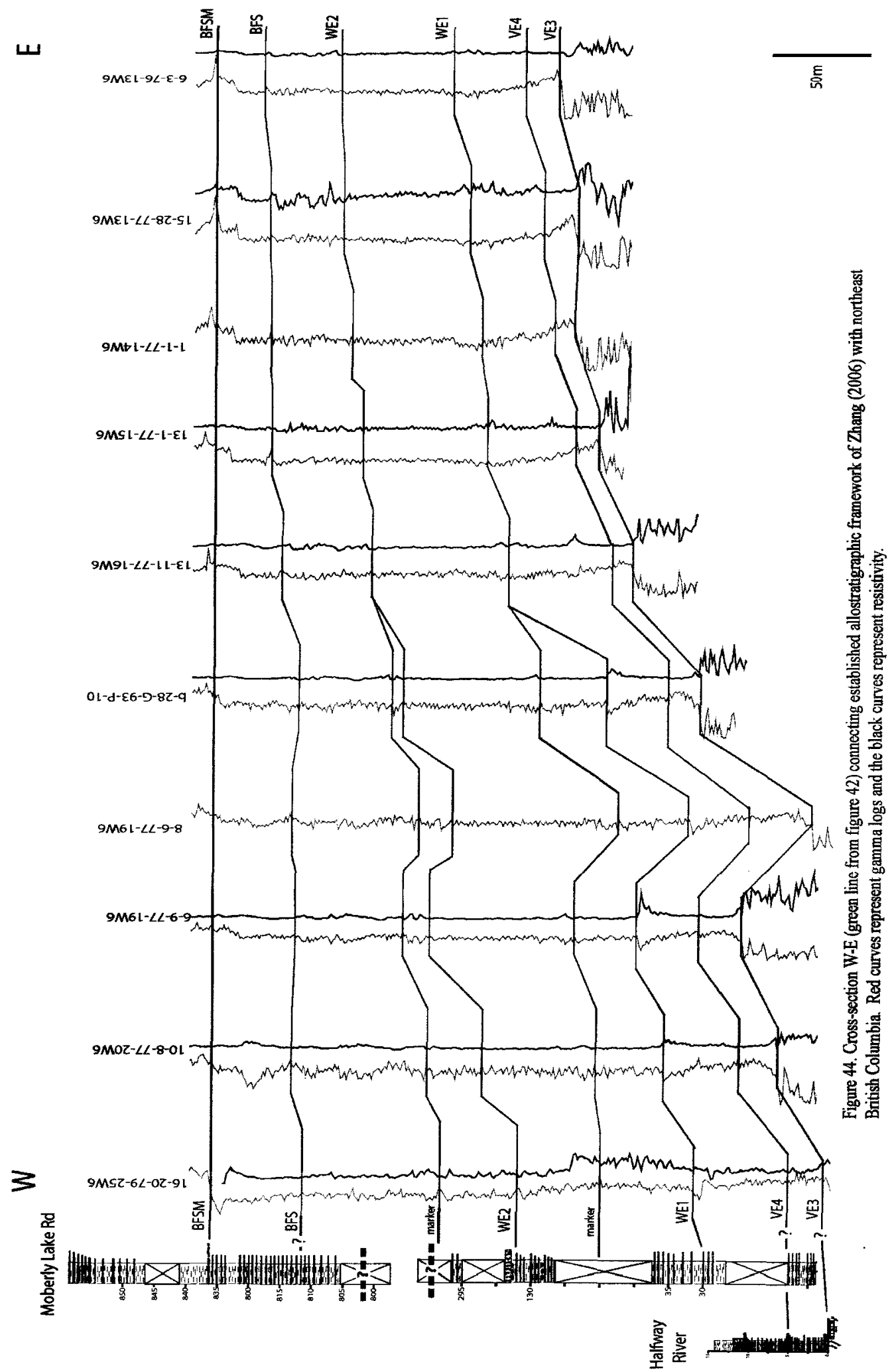


kilometres northwest, was calculated to be $850 \mathrm{~m}$ (figure 43 and 44 ) by assuming a consistent dip angle throughout all covered intervals. Foraminiferal indicator taxa and their corresponding allomembers in the initial $130 \mathrm{~m}$ (sections a-d in figure 27) correlate well with surfaces extended from the Hudson Bay et al. Moberly 16-20-79-25W6 well. This interval is followed by $660 \mathrm{~m}$ of section, of which, only six meters are exposed introducing much uncertainty. The remaining $60 \mathrm{~m}$ of section ( $\mathrm{g} \& \mathrm{~h}$ from figure 27 ) are more confidently placed in the vicinity of the Fish Scale Marker Bed. This position is supported by high gamma readings followed by a barren interval (allomember FB) changing into the Verneuilinoides perplexus Zone. It seems plausible that the Moberly Lake Road section contains a fault with repeated section and/or that the shallowly dipping strata become horizontal in the covered interval making section thicknesses inaccurate. 


\section{DISCUSSION}

\section{A biostratigraphic zonal scheme using allostratigraphy}

One of the main objectives of this study is the establishment of a foraminiferal zonal scheme in relation to the newly developed allostratigraphic framework in western Alberta and northeastern British Columbia. The extensive allostratigraphic framework proposed by Zhang (2006) and Roca (2007) has provided a physical stratigraphy linking the subsurface to outcrop in western Alberta. Previously, biostratigraphic work was integrated with lithostratigraphy, a methodology that resulted in numerous conflicting stratigraphic frameworks coupled with biostratigraphic subzones that had only localized relevance. Foraminiferal data gathered shows that, within the study area, each foraminiferal assemblage (distinctive enough to have biostratigraphic value and therefore receiving zonal status) is found in a body of strata (allomember) bound by unconformities. In addition, the discovery of the complete section at Deadhorse Meadows and the sequential reoccurrence of its foraminiferal zones in near and distant outcrops provided confidence in establishing a new zonation. Figure 45 contrasts the existing zonation after Caldwell et al. (1993) with the one of this study where zones are correlated to allomembers. Figure 46 shows the schematic cross-section of allomember subsurface geometry in a NW-SE direction as developed by Roca (2007). Each allomember is now correlated with an index species. The reasoning for creating this new zonation and moving away from the existing one is discussed below. 


\section{CURRENT ZONATION}

\section{THIS STUDY}

\begin{tabular}{|c|c|c|}
\hline 2345 & SUBZONE & ZONE \\
\hline & Fish Scale Marker & \\
\hline & $\begin{array}{c}\text { Haplophragmium } \\
\text { swareni }\end{array}$ & \\
\hline & $\begin{array}{c}\text { Haplophragmoides } \\
\text { postis goodrichi }\end{array}$ & $\begin{array}{l}\text { ammina } \\
\text { ittobensis }\end{array}$ \\
\hline & $\begin{array}{l}\text { Verneuilinoides } \\
\text { canadensis }\end{array}$ & \\
\hline & Reophax troyeri & \\
\hline & $\begin{array}{l}\text { Trochammina } \\
\text { umiatensis }\end{array}$ & \\
\hline & $\begin{array}{l}\text { Trochammina } \\
\text { depressa }\end{array}$ & \\
\hline & $\begin{array}{c}\text { Reophax } \\
\text { tundraensis }\end{array}$ & \\
\hline & Haplophragmoides & \\
\hline & $\frac{\text { glgas phaseolus }}{\text { Haolophraomoldes }}$ & \\
\hline & iglas algas. & \\
\hline & $\begin{array}{l}\text { Haplaphragmoldes: } \\
\text { uniorbis: }\end{array}$ & \\
\hline & $\begin{array}{c}\text { Ammobaculites } \\
\text { wenonahae }\end{array}$ & $\begin{array}{c}\text { Gaudryina } \\
\text { nanushukensis }\end{array}$ \\
\hline
\end{tabular}

3456 ZONE

ALLOMEMBER

\begin{tabular}{|c|c|c|}
\hline \multicolumn{2}{|c|}{ Fish Scale Marker } & FB \\
\hline $\begin{array}{l}\text { Haplophragmium } \\
\text { swareni }\end{array}$ & \multirow{2}{*}{ 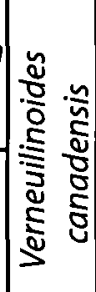 } & WC + FA \\
\hline $\begin{array}{c}\text { Trochammina } \\
\text { umiatensis }\end{array}$ & & WB \\
\hline \multicolumn{2}{|c|}{$\begin{array}{l}\text { Haplophragmoides } \\
\text { postis goodrichi }\end{array}$} & WA \\
\hline \multicolumn{2}{|c|}{$\begin{array}{l}\text { Haplophragmoides } \\
\text { multiplum }\end{array}$} & VD \\
\hline
\end{tabular}

\section{OUTCROP LEGEND}

1: Sikanni Chief River

2: Dokie Ridge

3: Halfway River

4: Moberly Lake Road

5: Hasler Creek

6: Deadhorse Meadows

Figure 45. Left diagram shows the current foraminiferal zonation (Caldwell et al. 1993) along with the outcrops used to create the subzonation in northeast British Columbia. The right diagram shows

foraminiferal zones from this study along with selected outcrops from the study. 


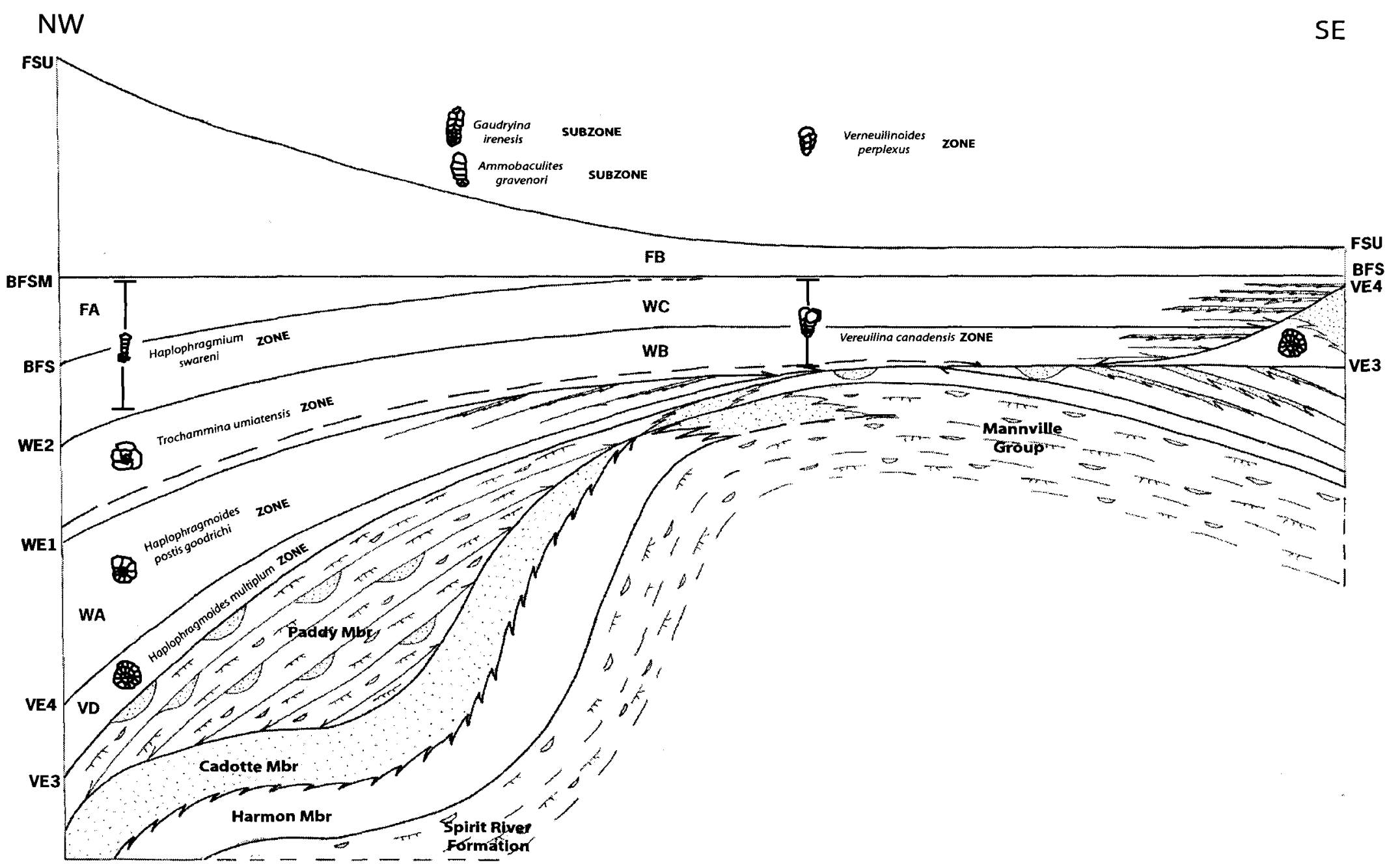

Figure 46. Schematic NW/SE cross-section from northwestern British Columbia to western Alberta showing the sequence of allomembers bounded by erosional surfaces and the distribution of foraminiferal zones. Modified from Roca 2007. See figure 4 for position of cross-section. See figure 4 for position of cross-section. 


\section{Lithostratigraphic vs. allostratigraphic biostratigraphy}

The current foraminiferal zonation after Caldwell et al. $(1978,1993)$ has been based on the concept of lithostratigraphy and a multitude of outcrops, which at the time were not allostratigraphically correlated. Figure 45 shows the current foraminiferal zonation and the sections used by Stelck et al. $(1956,1958)$, Sutherland and Stelck (1972), Stelck (1975, 1991, 2000), Stelck and Hedinger (1983), Koke and Stelck (1984, 1985) and Stelck and Koke (1987) to create that zonation in contrast to the new zonation using allomembers. Utilized outcrops for the new zonation include some of the short intervals of the previous authors that were revisited in addition to the newly discovered extensive reference section at Deadhorse Meadows (figure 45).

An important finding of this study is the difference in thickness of the Hasler interval in the Peace River area as determined by use of allostratigraphic correlations. Stelck and Koke (1987) and Stelck (1991) proposed a thickness of $530 \mathrm{~m}$ for the Hasler Formation based on the Hudson Bay et al. Moberly 16-20-79-25W6 well. Lithostratigraphically, their Hasler interval ranges from the top of the Boulder Creek Formation ("Cadotte" equivalent) to the base of the Goodrich Sandstone (Fig. 4 in Stelck and Koke, 1987). Using wireline logs (figures 43 and 44) this study has determined that the thickness of the Hudson Bay et al. Moberly 16-20-79-25W6 well is 310 m covering the interval from the VE3 to FSMB surfaces. In terms of lithostratigraphy this interval represents the very top of the Boulder Creek, Hasler, Goodrich and lower Cruiser formations representing a larger lithostratigraphic interval. Equivalent lithostratigraphic units in the subsurface would include in ascending order the uppermost Viking and Westgate formations (figure 5). 
The Sun et al. Chetwynd 14-20-77-23W6 well lies $65 \mathrm{~km}$ southeast of the Hudson Bay et al. Moberly 16-20-79-25W6 well where Stelck and Koke (1987) and Stelck (1991) calculated $230 \mathrm{~m}$ of Hasler Formation. Using the allostratigraphic surfaces the Chetwynd 14-20-77-23W6 well (figures 43 and 44) I interpret $300 \mathrm{~m}$ of strata from the VE3 surface to the FSMB surface. While Stelck and Koke (1987) and Stelck (1991) show a doubling of the thickness of the Hasler over $65 \mathrm{~km}$ from the Chetwynd 14-20-77-23W6 well (230 m) to the Hudson Bay et al. Moberly 16-20-79-25W6 well (530 m), this study shows only a $10 \mathrm{~m}$ increase in thickness over the $65 \mathrm{~km}$. Approximately $30 \mathrm{~km}$ west of the Moberly Lake Road section Stott (1982) recognized $265 \mathrm{~m}$ of Hasler shale in the type section at Dokie Ridge where he measured from the top of the Boulder Creek Formation to the base of the Goodrich Formation. Considering the wireline log data from this study and the thickness of the Hasler given by Stott (1982) it seems likely that Stelck and Koke (1987) and Stelck (1991) have overestimated the thickness of the Hasler shale in the Hudson Bay et al. Moberly 16-20-79-25W6 well.

The foraminiferal zonation after Caldwell et al. (1993) shows two zones and ten subzones (figure 45) within the Hasler and Goodrich formations in the Peace River area. In looking at the outcrops used in the current zonation (figure 45) it can be seen that none show a great degree of stratigraphic completeness. In fact, many of the subzones are only partially represented in outcrop and boundaries have been placed arbitrarily. For example Stelck and Koke (1987) state that the Haplophragmoides phaseolus Subzone has no clear boundary with the underlying $H$. gigas gigas Subzone. Another complication with the existing subzonal scheme stems from the use of subspecies such as Haplophragmoides gigas gigas and $H$. gigas phaseolus formerly introduced as $H$. gigas ssp. A (Stelck and 
Koke, 1987). These subzones are based on intraspecific variability that could easily be a response to changing facies and therefore have no biostratigraphic significance.

Despite resampling the Moberly Lake and Halfway River outcrops the subzones of the Haplophragmoides gigas Zone including the H. uniorbis, H. gigas gigas, $H$. gigas phaseolus, Reophax tundraensis, Trochammina depressa and Roephax troyeri could not be recognized. Some of these species were found, but neither with distinctive abundance nor range to justify zonal status.

While faunal elements found within this study are similar to Miliammina manitobensis Zone after Caldwell et al. $(1978,1993)$ some changes have been made. This study creates zones in reference to allomembers and purposefully does not use the species Miliammina manitobensis as an indicator species because of its long biostratigraphic range (figure 47). Figure 45 shows the zones from this study in stratigraphic order.

\section{Haplophragmoides multiplum Zone}

The Haplophragmoides multiplum Zone is a thin zone associated with allomember VD between the VE3 and VE4 erosional surfaces (figure 46). In the northern portion of the study area this zone is recognized in the Mount Belcourt, Moberly Lake Road and Halfway River outcrops. Roca's (2007) schematic allomember cross-section from the Deadhorse Meadows to the Fall Creek region (figures 1 and 4) indicates the presence of allomember VD in the NW and SE, but being eroded or non-deposited over the forebulge. Micropaleontolgical analysis of several Fall Creek outcrops (pers. comm. SchröderAdams, 2007) supports the presence of $H$. multiplum in allomember VD. The identification of this species at this interval in a previously described Fall Creek outcrop originally led to the incorrect identification of the Middle Albian Hulcross/Harmon 


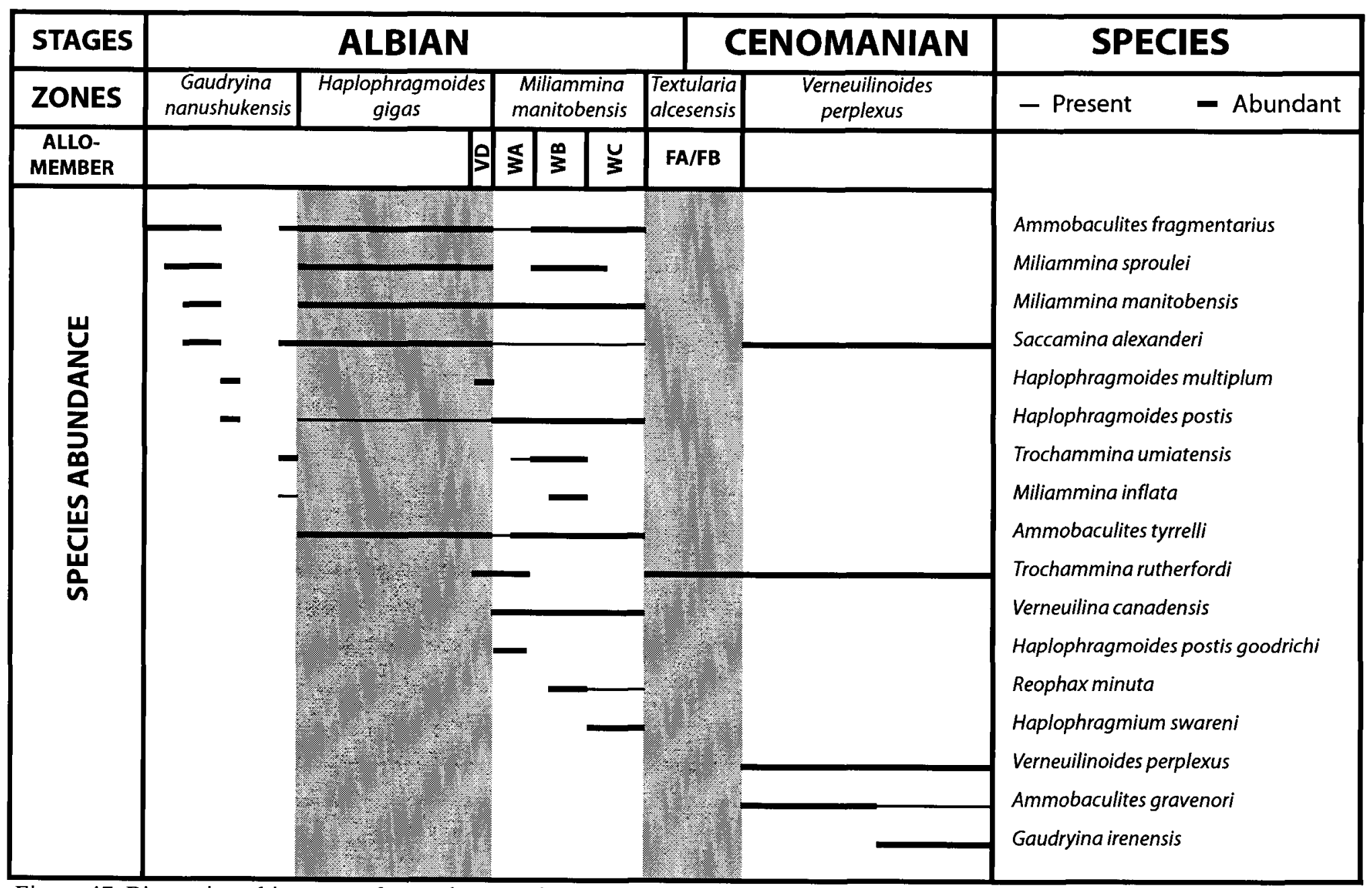

Figure 47. Biostratigraphic range of some key species in the Albian and Cenomanian strata of western Canada and allostratigraphic members. Ranges after Caldwell et al. 1978, 1993; this study and allomembers after Roca (2007). 
stratigraphic interval at this location (Leckie et al., 2000). At the time, this

biostratigraphic call was based on the zonation of Caldwell et al. (1993) who associated this subzonal index for the Harmon /Hulcross transgression. Integration with Roca's allostratigraphic framework now shows the association with allomember VD extending the range of $H$. multiplum from the Middle Albian to the early late Albian Viking Formation (allomember VD)

\section{Haplophragmoides postis goodrichi Zone}

The Haplophragmoides postis goodrichi Zone is recognized only in the northern portion of the study area and pinches out southward towards the forebulge (fig 46). This zone lies between the VE4 and WE1 erosional surfaces and is recognized by the abundant and dominating occurrence of Haplophragmoides postis goodrichi, which is present only within the WA allomember. This zone is recognized in the Halfway River, Deadhorse Meadows, Nickerson Creek, Moberly Lake Road and Sulphur River outcrops, all northern sections in the study area. In the current zonation by Caldwell et al. $(1978,1993)$ Haplophragmoides postis goodrichi is the middle of three subzones in the Miliammina manitobensis Zone (figures 6 and 45). Originally, Sutherland and Stelck (1972) described this subzone in the Moberly Lake Road outcrop and placed it on top of the Verneuilina canadensis Subzone. As shown in figure 45 this study places the Haplophragmoides postis goodrichi Zone stratigraphically lower and below the Verneuilina canadensis Subzone. This confirms observations by Stritch and Schröder-Adams (1999) who also placed the Haplophragmoides postis goodrichi Subzone below the Verneuilina canadensis Subzone in the Spirit River 12-20-78-6W6 well near Peace River Town. Allomember WA is not present in the southern region of Fall Creek (figure 46), 
confirmed by the absence of the H. postis goodrichi Zone in the Fall Creek outcrops (pers. comm, Schröder-Adams, 2007).

\section{Trochammina umiatensis Zone}

The Trochammina umiatensis Zone is recognized throughout the entire study area and lies between the WE1 and WE2 erosional surfaces associated with allomember WB (figures 46). This zone is recognized in the Deadhorse Meadows, Nickerson Creek, Sulphur River, Mount Belcourt, Moberly Lake Road and core 13-11-41-26W4. Trochammina umiatensis has been used as a zonal marker here because it only occurs in the WB allomember where $H$. postis goodrichi disappears (figure 47) and its consistent occurrence in nearly all outcrops. The zonation of Caldwell et al. (1993) also recognized this species as a subzonal index where it was found in the Moberly Lake and Hasler Creek localities.

\section{Haplophragmium swareni Zone}

The Haplophragmium swareni Zone is recognized in the northern portion of the study area in the interval from the WE2 surface to the BFSM surface (figure 46). This zone corresponds to the WC and FA allomembers. It is only represented in the Deadhorse Meadows and Moberly Lake Road outcrops. Large abundances of this species have been recognized farther north in the upper Buckinghorse Formation (SchröderAdams et al., 2003), Sikanni and lower Sully formations (Stelck and Hedinger, 1983; Schröder-Adams pers. comm., 2007). This species was also used by Caldwell et al., $(1978,1993)$ where it takes the highest subzone of the Miliammina manitobensis Zone (figure 45). In the southern portion of the study area the condensed nature of the strata 
produce an assemblage that has common elements of the Trochammina umiatensis and Haplophragmium swareni zones (WB and WC allomembers) (figure 46) .

In western Alberta the Textularia alcesensis Zone (found above the $H$. swareni Subzone of Caldwell et al. 1993) has been found locally in the interval straddling the Fish Scale Marker Bed (Stelck et al., 1958; Caldwell et al., 1978; Leckie et al., 2000) but is absent over most of the WCSB (Bloch et al., 1993). The T. alcesensis was not encountered in this study despite being originally recognized in the Peace River area. It might represent a facies related occurrence.

\section{Verneuilina canadensis Zone}

The Verneuilina canadensis Zone is recognized southeast of the forebulge between the WE1 and BFSM erosional surfaces (figure 46) where it encompasses both the WB and the WC allomembers. V. canadensis was found in cores 13-11-41-26W4 and 8-20-44-3W5 and in the Fall Creek sections (Schröder-Adams, pers. comm. 2007) in the same allomembers. The original foraminiferal zonation by Caldwell et al. $(1978,1993)$ agrees that east of the foredeep the three part subdivision of the Miliammina manitobensis Zone (figure 6) is replaced by a single subzone of $V$. canadensis, which contains elements of the Trochammina umiatensis and Haplophragmium swareni zones.

\section{Verneuilinoides perplexus Zone}

The allostratigraphic model (Roca 2007) reaches up to the FSU erosional surface above the Fish Scale Marker Bed. The FB allomember, bound by these two surfaces, is barren of foraminifera throughout the entire study interval, a well documented fact by Schröder-Adams et al. (1996) who described the disappearance of all Albian species at 
the base of the Fish Scales Formation in central and southern Alberta. Above FSU, outside of the allostratigraphic framework and further up within the Cenomanian, the Verneuilinoides perplexus Zone is present within the Moberly Lake Road and Deadhorse Meadows outcrops. This zone follows the original zonation created by Caldwell et al. $(1978,1993)$ with its two subzonations recognized in the study area (figure 46). In the

Deadhorse Meadows section both the Ammobaculites gravenori and Gaudryina irenensis subzones are present. In the Moberly Lake Road section only the Gaudryina irenensis Subzone is recognized.

\section{Foraminifera as paleoenvironmental proxies in sequence stratigraphy}

The integration of biostratigraphy with allostratigraphy in this study has proven superior over the integration with lithostratigraphy. Other authors have integrated their paleontological data with the more widely used method of sequence stratigraphy, a methodology that uses cyclic and genetically related stratal units resulting from sea-level change, and have also considered it as superior over lithostratigraphy (Brett, 1995; Abbott and Carter, 1997 and Brett, 1998). Given that many fossils are facies controlled, sequence stratigraphy becomes a tool for predicting the distribution of fossils in space and time. Thus, it is not only patterns of the first and last occurrence of species that can be understood, but also changes in the abundance, species composition, paleoecological attributes and taphonomic features. By using the succession of sequence system tracts, their distribution through time and their lateral correlation, a wealth of patterns at higher stratigraphic resolution can be studied with time-environment analysis.

The processes of sea-level, climate, and sediment supply fluctuation have strong biological impacts, controlling spatial distribution of organisms at a variety of scales and 
influencing patterns of immigration, origination, and extinction (Bennett, 1990; Rey et al., 1993). Bathymetric and sedimentologic factors with associated parameters, in particular, exert major controls on the distribution patterns of marine benthic organisms. Because paleoecological changes in shallow marine settings are closely correlated with fluctuations in sea level and sedimentation, one may predict many relationships between fossil distributional patterns and depositional sequences.

Sequence stratigraphy in respect to paleobiological patterns has received increasing attention in recent years (Brett, 1995, 1998; Holland, 1999; Rey et al., 1993; Scarponi and Kowalewski, 2007). Table 3 shows a summary of important relationships between fauna and sequences observed by Rey et al., (1993), Scarponi and Kowalewski, (2007) and this study. In marine-shelf environments it is sometimes difficult to distinguish the different system tracts of a depositional sequence (Vail et al., 1984, 1987: Posamentier and Vail, 1988; Sarg, 1988). This is particularly true when dealing with homogeneous lithology and intermittent data. For shallow shelf settings, preservation of lowstand systems tracts are typically restricted or absent, and depositional sequences consist of genetically related transgressive and highstand deposits, bounded by erosional lowstand unconformities (Baum and Vail, 1988).

In identifying system tracts this study uses micropaleontological data and lithological observations and compares those to results by Scarponi and Kowalewski (2007) and Rey et al. (1993). Both authors observe under oxygenated marine conditions a higher number of species in the transgressive systems tract (TST) representing the colonization phase as favourable ecological conditions develop. In contrast, the highstand systems tract (HST) is characterized by reduced species richness due to domination of a few taxa. 


\begin{tabular}{|c|c|c|c|}
\hline STUDY & ENVIRONMENT & $\begin{array}{c}\text { SYSTEMS } \\
\text { TRACT }\end{array}$ & FAUNAL PATTERNS \\
\hline $\begin{array}{c}\text { Scarponi } \\
\& \\
\text { Kowalewski } \\
2007\end{array}$ & Shallow marine & $\begin{array}{l}\text { HST } \\
\text { TST }\end{array}$ & $\begin{array}{l}\text { Low species richness and dominance of most common species } \\
\text { High species richness and most abundant species less dominant } \\
\text { Species richness decreases upwards within sequences from TST to HST } \\
\text { Turnover across sequences is negligible compared to variation between } \\
\text { different systems tracts }\end{array}$ \\
\hline $\begin{array}{c}\text { Rey et al. } \\
1993\end{array}$ & Shallow marine & $\begin{array}{l}\text { HST } \\
\text { TST } \\
\text { LST }\end{array}$ & $\begin{array}{l}\text { Low species richness, maximum concentration in middle of deposit, } \\
\text { High species richness, maximum concentration in middle of deposit, } \\
\text { gradual colonization at first, then rapid } \\
\text { Robust test morphology, lowest diversity }\end{array}$ \\
\hline This Study & Shallow marine & $\begin{array}{l}\text { HST/FSST } \\
\text { TST } \\
\text { LST }\end{array}$ & $\begin{array}{l}\text { Low diversity and dominance of most common species, maximum } \\
\text { concentration in middle of deposit, low turnover } \\
\text { Sequence is barren } \\
\text { No preservation }\end{array}$ \\
\hline
\end{tabular}

Table 3. Summary of important relationships between fauna and sequences observed by; Rey et al., 1993; Scarponi and Kowalewski, 2007 and this study. LST: lowstand systems tract; TST: transgressive systems tract; HST: highstand systems tract; FSST: falling stage systems tract. 
On sedimentological basis my measured sections do not give evidence for the preservation of lowstand systems tract (LST) or TST. These mainly preserve in incised valley fills, which are not present within measured strata. Therefore assemblages described here might represent primarily HST and possibly falling stage systems tracts (FSST). Generally, numbers of species do not show a significant change between allomembers suggesting the preservation of the same sea-level phase, namely the HST, in most allomembers. Scarponi and Kowalewski (2007) and Rey et al. (1993) found an average of 19 species for their HST, a number comparable to numbers found in this study (Table 4). In terms of foraminiferal abundance Rey et al. (1993) observed maximum concentrations in the middle deposits of the TST and HST. In the Deadhorse Meadows outcrop for example peak foraminiferal abundances for allomembers WA, WB, WC and FA also occur in the middle of the deposit in a relatively fine grained mudstone. If only HST and possible FSST are preserved, physical sedimentological evidence indicating sequence boundaries should be expected in measured sections where the LST and TST are missing. Where in some instances these boundaries are pronounced as e.g. the presence of a coal bed or a pebble bed, others are not obvious. In these cases, foraminiferal assemblage changes give the most convincing evidence for a basin paleoecological change related to sea level.

The lowest Cenomanian strata require further discussion. All Albian foraminifera disappear within the FB allomember and the section remains barren. Benthic foraminifera only reappear in strata above the FSU surface. The lack of benthic species in correlative strata to FB has previously been interpreted as the result of anoxic bottom water conditions (Schröder-Adams et al., 1996). Rey et al., (1993) has seen similar faunal successions within sequences in anoxic basins where the TST lacks foraminifera and the 


\begin{tabular}{|c|c|c|}
\hline Allomember & $\begin{array}{c}\text { Species } \\
\text { richness }\end{array}$ & $\begin{array}{c}\text { Dominant } \\
\text { genera }\end{array}$ \\
\hline FB & $\begin{array}{c}3-13 \\
\text { species }\end{array}$ & $\begin{array}{c}\text { Saccammina } \\
\text { Bathysiphon }\end{array}$ \\
\hline FA & Barren & NA \\
\hline WC & $\begin{array}{c}12 \\
\text { species }\end{array}$ & $\begin{array}{c}\text { Ammobaculites } \\
\text { Miliammina }\end{array}$ \\
\hline WB & $\begin{array}{c}9-21 \\
\text { species }\end{array}$ & $\begin{array}{c}\text { Ammobaculites } \\
\text { Mriliammina } \\
\text { Trochammina } \\
\text { Miliammina }\end{array}$ \\
\hline WA & $\begin{array}{c}10-22 \\
\text { species }\end{array}$ & $\begin{array}{c}\text { Haplophragmoides } \\
\text { Ammobaculites }\end{array}$ \\
\hline VD & $\begin{array}{c}17-20 \\
\text { species }\end{array}$ & $\begin{array}{c}\text { Ammobaculites } \\
\text { Trochammina }\end{array}$ \\
\hline
\end{tabular}

Table 4. Foraminiferal species richness (variable number of species results from multiple outcrops) and dominant genera for allomembers and depositional sequences. 
following HST shows recolonization and diversification. Similarities between both studies support the interpretation of the FB allomember as being the TST representing the anoxic phase (see discussion below). In the HST (strata above FSU) foraminifera start to colonize the seafloor starting with primitive, one chambered forms such as the genus Saccammina and tubular taxa such as Bathysiphon followed by more sophisticated building plans. The tubular tests of Bathysiphon, living erect on the seafloor, also indicate a deeper and low energy paleoenvironment.

As discussed above, foraminiferal evidence suggests the predominant preservation of HST tracks in the recorded strata. This is in agreement with the sequence stratigraphic interpretation based on the new allostratigraphic framework that suggests that each allomember associated with Albian sediments represent the HST/FSST (Roca, pers. comm., 2007).

\section{Paleoshorelines}

Foraminiferal diversity is dependant on numerous ecological factors. Marginal marine environments generally have a reduced number of species that can tolerate extreme conditions often associated with these environments. Therefore interpretations of fossil assemblages cannot be decoupled from paleogeographic reconstructions and ancient shoreline positions. The fossil record of marginal marine environments suggests that such settings tend to be represented by relatively fewer taxa e.g. (Baumbach, 1977; Kowalewski et al., 2002) dominated by opportunistic species with intermittently explosive population growths. Studying the allomember WA and its foraminifera in various outcrops makes this point. In the southeastern outcrops of Sulphur River and Nickerson Creek the species richness is 13 and 10 respectively. The allomember WA in 
these two outcrops is almost exclusively dominated by Haplophragmoides postis goodrichi making up 50 to 67 percent respectively of all specimens. Moving northwest, abundance of $H$. postis goodrichi peaks at the Deadhorse Meadows outcrop increasing to 80 percent of all specimens despite a slightly higher total number of 18 species. North of Deadhorse Meadows species richness increases to 22 species but with decreasing dominance. Paleogeographic maps by Roca (pers. comm. 2007) indicate that during deposition of WA the paleoshoreline was close to the Deadhorse Meadows, Nickerson Creek and Sulphur River outcrops. This is supported by a coal bed at the WE1 surface (WE1 forms the upper boundary of allomember WA) at Deadhorse Meadows indicating a nearshore marsh environment. The increase in species richness and greater evenness of species (loss of dominance of Haplophragmoides postis goodrichi) at Halfway River suggests a more seaward position for WA in the northwest or at least more fully marine conditions.

\section{Use of morphotypes}

Paleoenvironmental data of the past several million years have recorded an impressive record of sea-level rise and fall that is preserved in both strata of continental margins and isotopes of deep-sea carbonates (Tibert and Leckie, 2004). To identify comparable patterns with fossil assemblages we often rely on proxy data that compare the Recent with the Past.

The abundance and well known ecological preferences of different morphotypes in modern agglutinated foraminifera are the basis for the following interpretations. Jones and Charnock (1985) highlighted the potential to make paleoecological inferences using 
modern agglutinated foraminifera that are differentiated into morphogroups based on their different test morphologies, life position and associated feeding strategies. I have adopted this approach to facilitate comparison of Recent with Cretaceous taxa for paleoenvironmental reconstructions. Table 5 is modified from Jones and Charnock (1985) by combining their morphotypes, feeding strategies, life positions and ecological requirements with genera found in this study. Using this data one can make a number of paleoenvironmental interpretations.

\section{Paleobathymetry}

Paleontologic data frequently provides a far more sensitive gauge of relative water depth than do sedimentologic features (Brett, 1998). Throughout evolution specific organisms tend to be conservative with respect to their preferred depth ranges. Hence, most genera and families seem to have occupied similar bathymetric zones for millions of years (Boucott, 1990; Aberhan, 1994).

The breakdown of foraminifera based on generic morphologies in selected outcrops is shown in figures $48 \mathrm{a}, \mathrm{b}$ and c. Figure 49 is modified from Jones and Charnock (1985) and shows the breakdown of relative proportions of morphotypes in neritic environments from marsh to outer shelf. Foraminiferal test morphologies are subdivided into planispiral, serial/uncoiling, quinqueloculine and trochospiral. When applying this model to the Western Interior Sea, it is important to keep in mind its unusual paleoecology related to e.g. basin restriction, prevailing relative shallow bathymetry and lowered salinities. Furthermore, the Cretaceous marine settings cannot be discussed without taking anoxic events into account (Jenkyns, 1980). These factors and their widespread influence throughout the basin may have overprinted the distribution of 


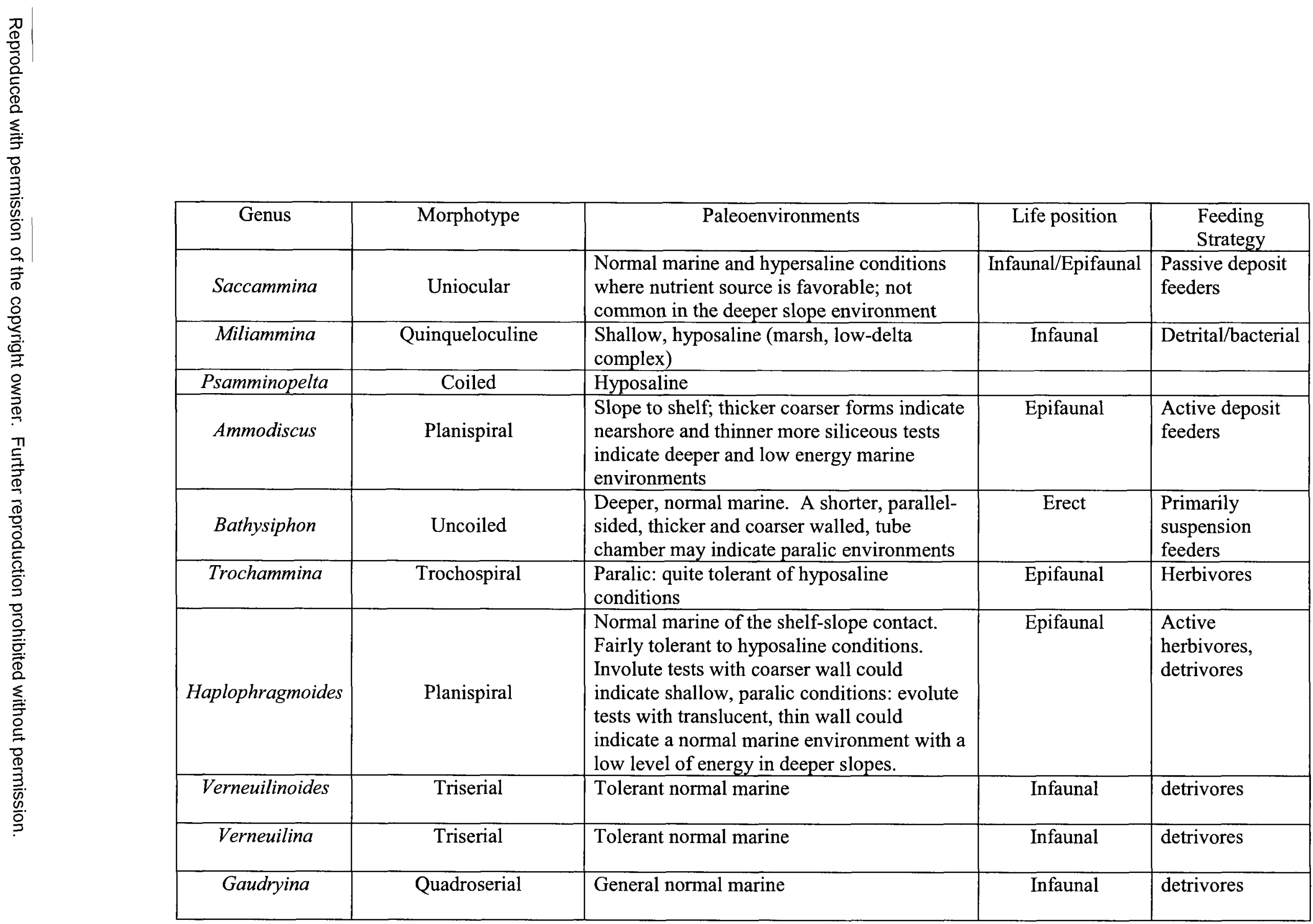

Table 5. Paleoenvironment, life position, and feeding strategy of foraminera genera based on morphotypes. Modified from Chamney

(1976) and Jones and Charnock (1985). 


\begin{tabular}{|c|c|l|l|l|}
\hline Gravellina & Serial & Tolerant to less favorable normal marine & Infaunal & detrivores \\
\hline Textularia & Biserial & $\begin{array}{l}\text { Normal marine with relatively moderate } \\
\text { energy level/ coarser test wall indicates } \\
\text { higher energy level and greater amounts of } \\
\text { silica cement indicate lower energy level }\end{array}$ & $\begin{array}{l}\text { Infaunal } \\
\text { bacterial/ } \\
\text { scavengers }\end{array}$ \\
\hline Ammobaculites & $\begin{array}{l}\text { Cormal marine to hyposaline, from } \\
\text { nearshore, to shallow shelf to slope }\end{array}$ & Infaunal & $\begin{array}{l}\text { Detrital/ } \\
\text { bacterial } \\
\text { scavengers }\end{array}$ \\
\hline Reophax & uniserial & $\begin{array}{l}\text { All normal marine environments of the shelf } \\
\text { and slope. Not tolerant to environmental } \\
\text { changes. }\end{array}$ & $\begin{array}{l}\text { Infaunal } \\
\text { bacterial/ } \\
\text { scavengers }\end{array}$ \\
\hline
\end{tabular}

Table 5 continued 


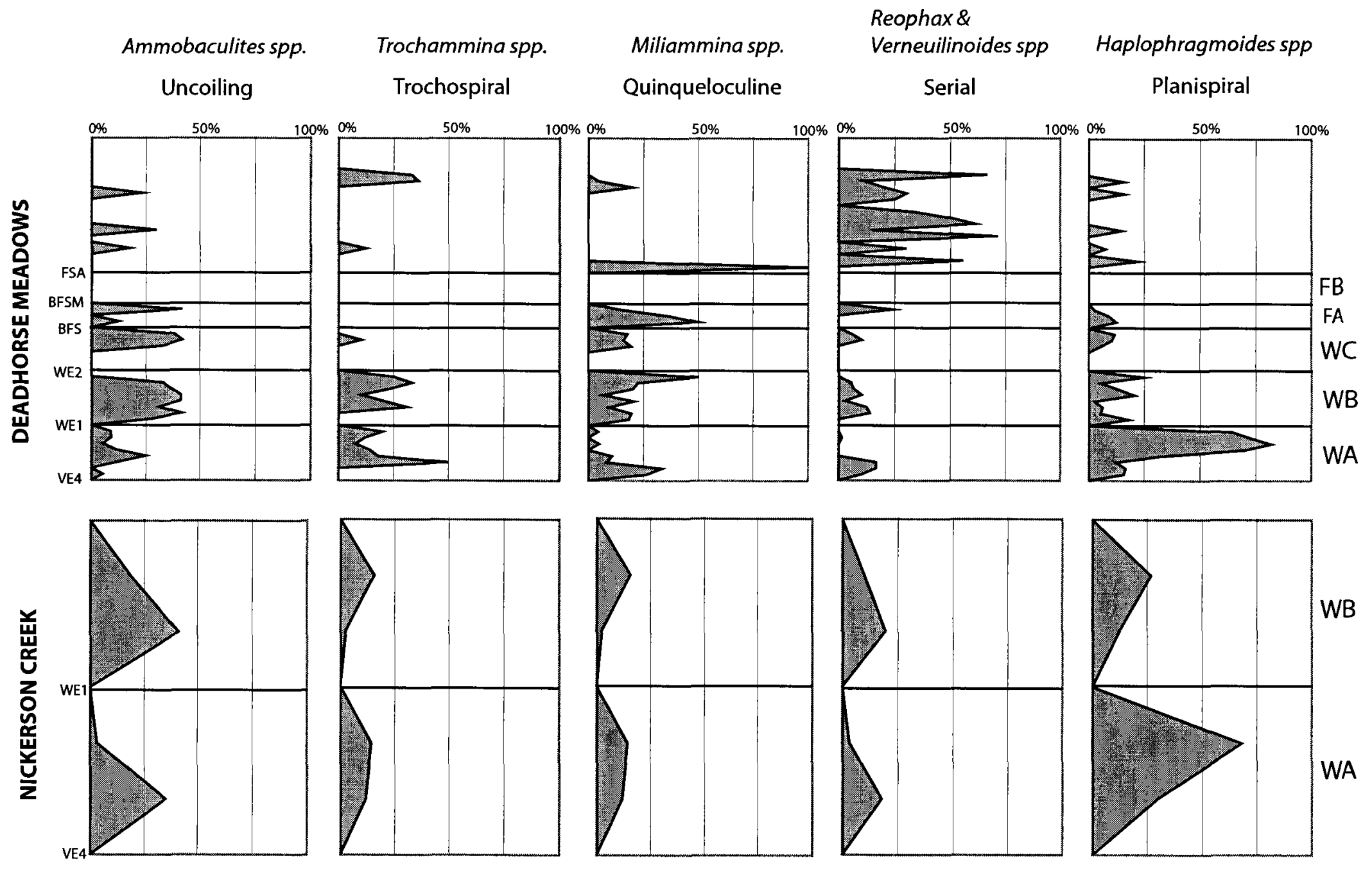

Figure 48a. Foraminiferal morphotypes shown as a percentage of entire sample with erosional surfaces labeled on the left and allomembers labeled on right. 


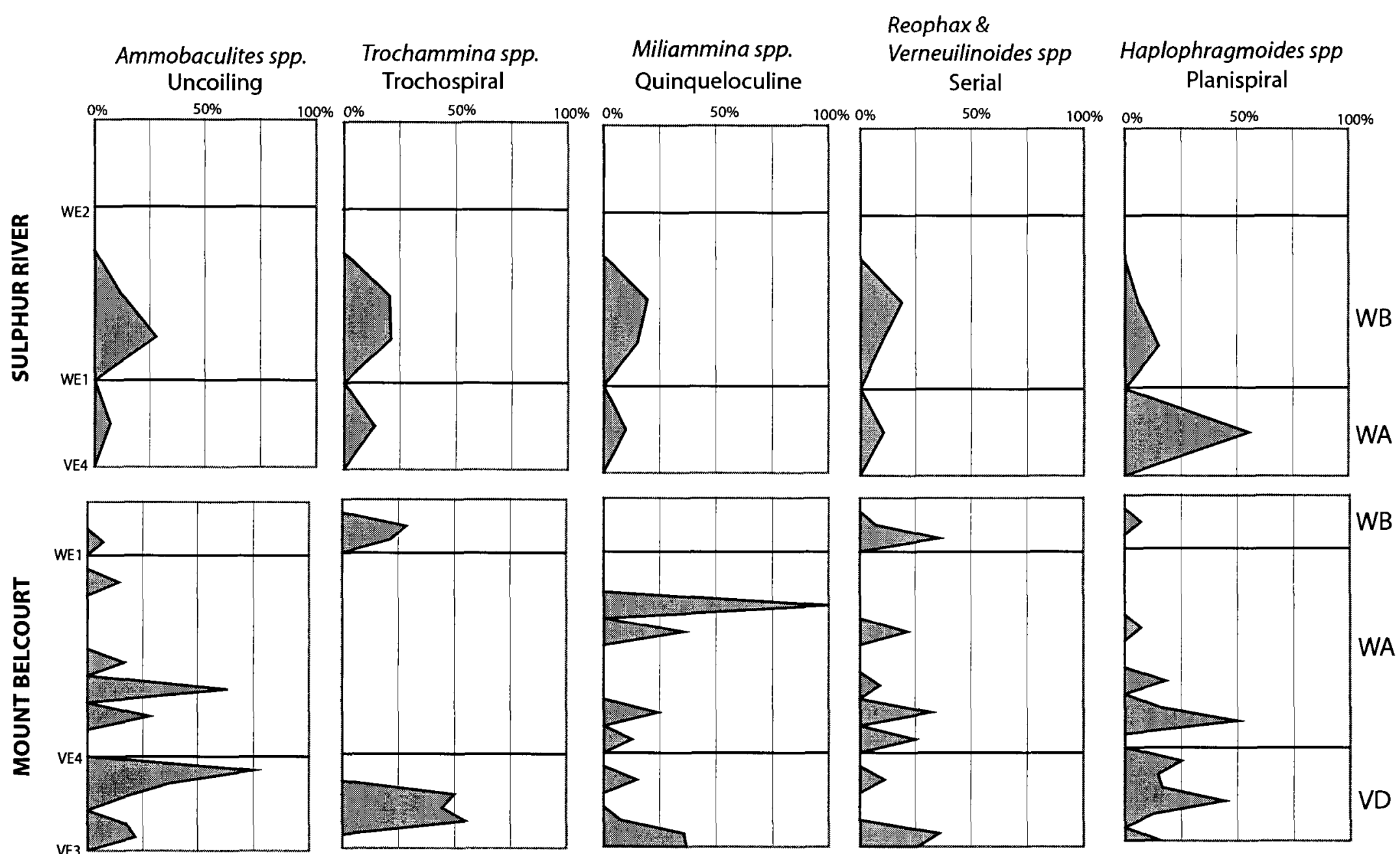

Figure 48b. Foraminiferal morphotypes shown as a percentage of entire sample with erosional surfaces labeled on the left and allomembers on the right. 


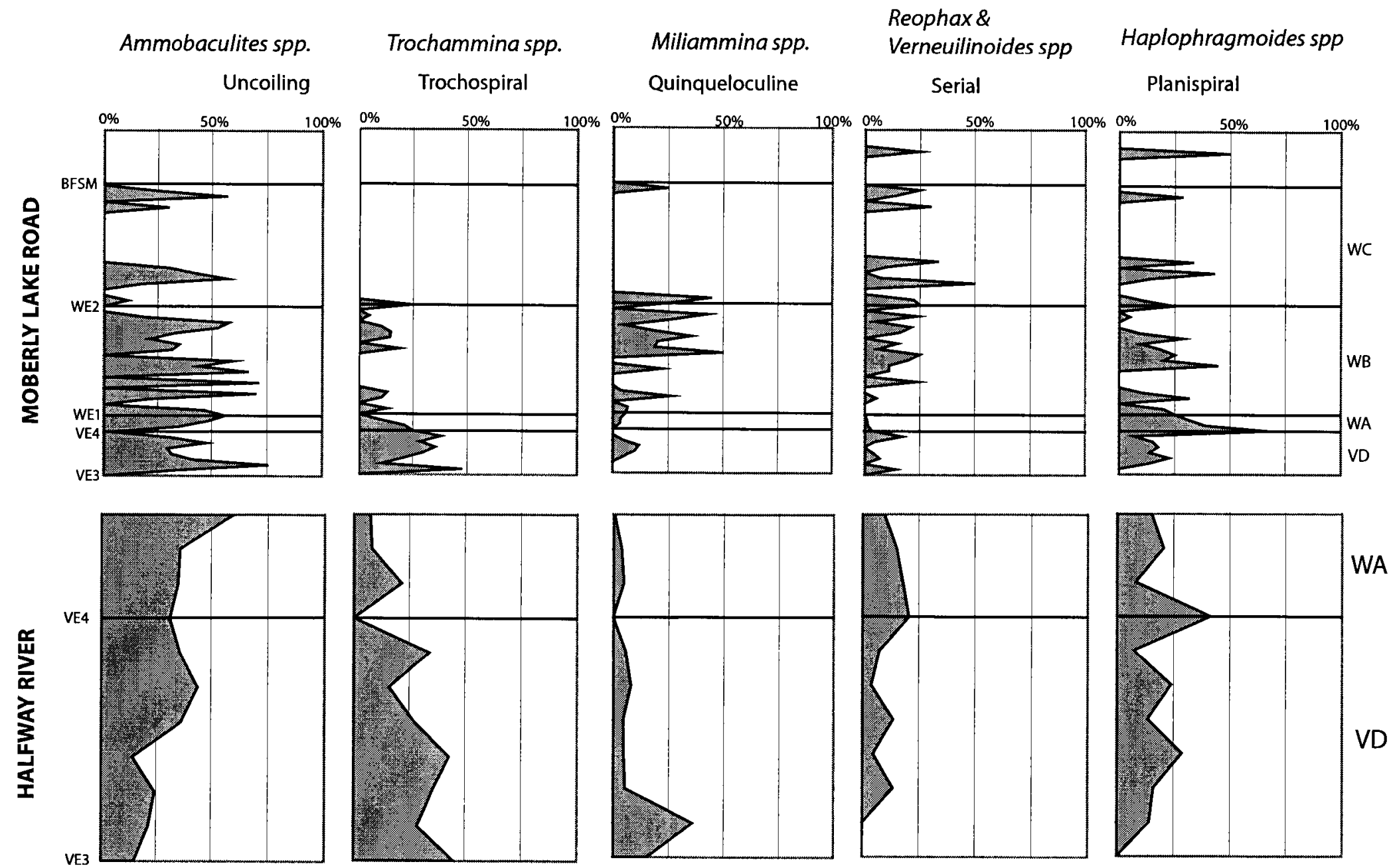

Figure 48c. Foraminiferal morphotypes shown as a percentage of entire sample with erosional surfaces labeled on the left and allomembers on the right. 


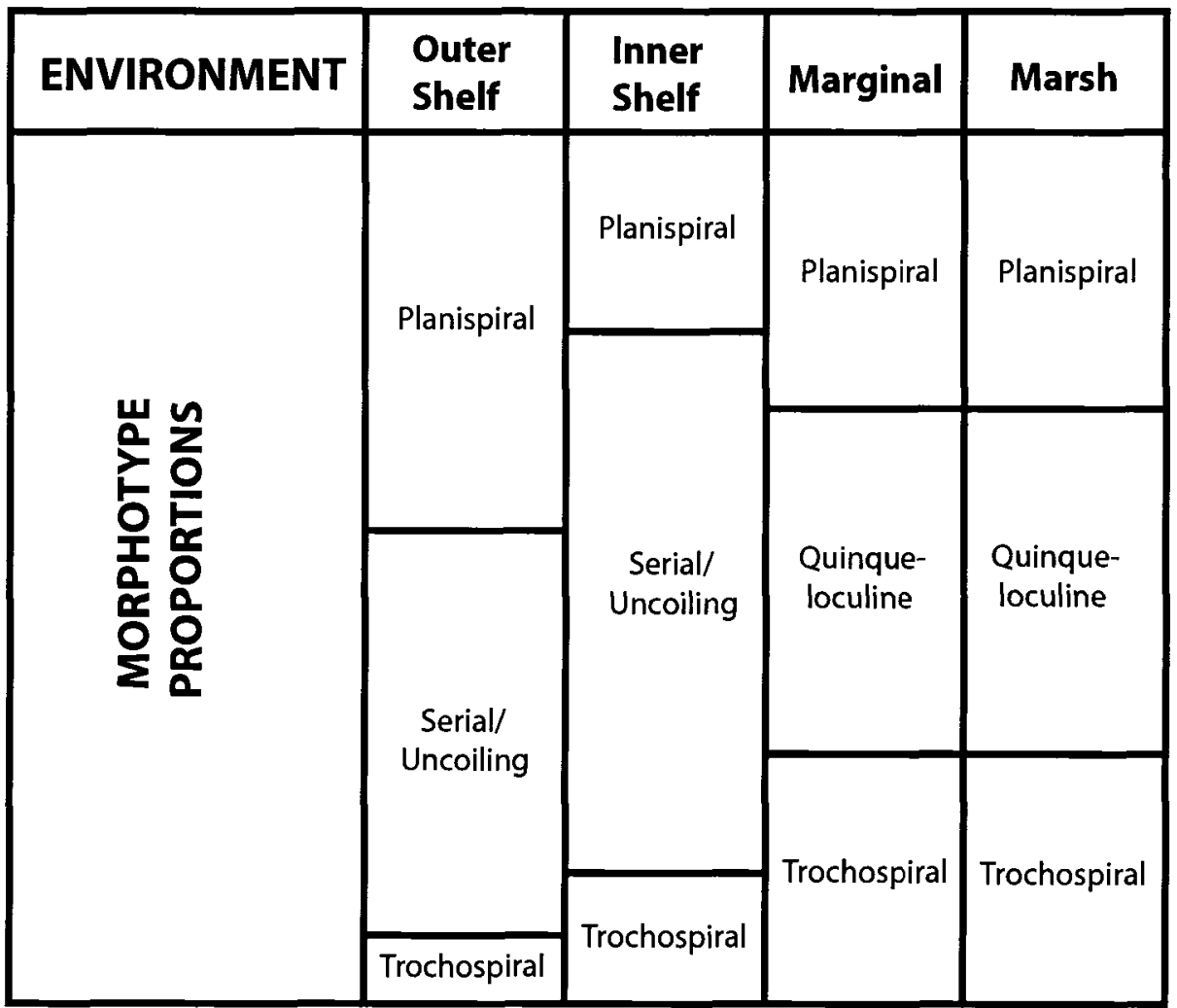

Figure 49. Relative abundances of morphotypes in neritic environments modified from Jones and Charnock (1985). 
morphotypes resulting in less distinctive trends when compared with open oceanic settings.

Nevertheless, a changing dominance in test morphologies can be best observed in the reference section at Deadhorse Meadows (figure 48 a). The lowest allomember WA contains dominantly planispiral and to a lesser degree quinqueloculine and trochospiral morphotypes. This combination indicates a marginal marine environment (figure 49 and 50), also supported by the nearly monospecific assemblage of the Haplophragmoides postis goodrichi Zone in this allomember as discussed above. Paleoshoreline maps by Roca (2007) also indicate that during WA time the shoreline was near the Deadhorse Meadows locality. In contrast, the WA allomember in Halfway River contains more uncoiling/serial morphotypes (figure 48c) that suggest a deeper marine setting further northwest of Deadhorse Meadows. The middle allomembers (WB, WC, FA) show a dominance of uncoiling and quinqueloculine forms suggesting a slightly deeper paleoenvironment from marginal to inner shelf settings (figure 49 and 50). The upper portion of the section that falls within the Cenomanian is mainly characterized by serial and uncoiled foraminiferal tests with a distinct decrease in other morphotypes (figure 48a) pointing towards offshore conditions (figure 49 and 50). For example, suspension feeders that are uncoiled (table 5) require lower energy conditions. At this time, paleoecology changes with the onset of the Greenhorn Transgression (Kauffman, 1977) (figure 2). Due to the incompleteness of the other outcrops morphotype distributions are more difficult to interpret (figures $48 \mathrm{a}, \mathrm{b}$ and c).

Paleoenvironmental analysis of sedimentological facies (table 2) agrees with paleontological interpretations based on foraminifera and their morphotypes. Outcrops 


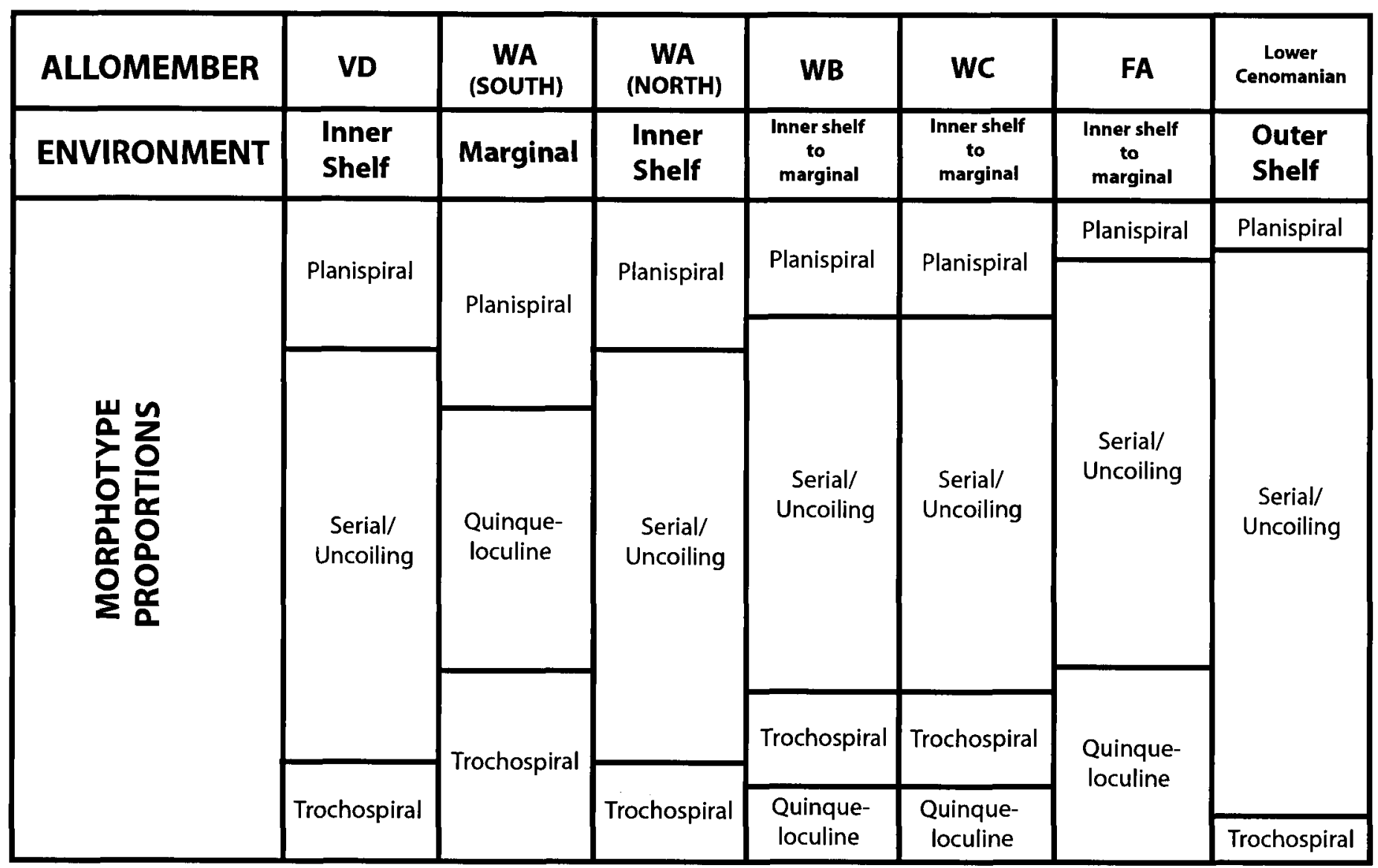

Figure 50. Relative abundaces of morphotypes in allomembers and environments. Modified from Jones and Charnock (1985). 
contain sheet-like sandstones often showing current ripples and fine to medium grained hummocky cross-stratified sandstone (facies II \& III from table 2) agreeing with the inner shelf setting interpretation of the middle allomembers. The FB allomember is barren of foraminifera in all outcrops making paleontological based estimates of paleobathymetry difficult. At Deadhorse Meadows where the full allomember is preserved the section consists of a platy grey mudstone, abundant fish scales and minor very fine sandstone beds that are parallel laminated or contain starved ripples. These features indicate an environment below fair weather wave base, an offshore shelf environment. Above the FB allomember the facies becomes mudstone rich with occasional coarser storm beds. These features are characteristic of shallow marine environments in the lower shoreface setting (Clifton, 1986). The overall deepening from shoreface to upper and lower offshore regions (table 2) triggers the morphological change in foraminiferal faunas to uniserial and uncoiled morphotypes, which is the most pronounced foraminiferal change within the studied interval.

\section{Paleosalinity}

The Albian to Cenomanian foraminiferal species identified in this study show an affinity to Boreal agglutinated assemblages of the Albian Tuktu and Grandstand formations of northern Alaska, described by Tappan (1962), Berquist (1966), and Sliter (1979). Particularly the Albian Mowry Sea which was dominated by a cool, low salinity watermass of Boreal affinity (Stelck, 1975; Schröder-Adams et al., 1996; Stritch and Schröder-Adams, 1999) that resulted in an assemblage dominated by agglutinated foraminifera. In modern settings agglutinated assemblages are indicative of hyposaline 
conditions in shallow water settings and in deepest waters that fall below the Calcium Compensation Depth.

Reduced salinities during the restricted phases of the Western Interior Sea may account for the abundance of the quinqueloculine morphotype (e.g. the genus Miliammina) which according to Jones and Charnock (1985) should be most common in marsh and marginal marine environments (figure 49). Numerous studies of Recent and fossil assemblages use the quinqueloculine morphotype as a proxy for reduced salinity environments (Scott et al., 1980; Culver et al., 1996; Tibert and Leckie, 2004). In this study the quinqueloculine morphotype is dominant in the WB, WC and FA allomembers (table 4), suggesting reduced salinities during the deposition of these allomembers.

\section{Lower Cenomanian anoxia}

Benthic communities may signal bottom-water oxygen levels (Sageman, 1989) and help to identify oxygen depletion events. The end of the Albian is marked by a widespread disappearance of Albian foraminiferal species within the Canadian portion of the Western Interior Sea. This horizon is marked by a bioclastic conglomerate or sandstone followed by a claystone to mudstone interval rich in phosphatic debris (Leckie et al., 1992; 2000; Bloch et al., 1999). Although no total organic carbon content was measured in the studied sections, in southern and central Alberta a clear increase is reported at this horizon (Bloch et al., 1999). The high gamma ray signature of the Fish Scale Marker Bed (BFSM) makes it an important wireline log marker throughout the basin. The concentration of phosphatic material often related to fish debris depends on local sedimentation rates. The bioclastic component of this bed in the Rocky Mountain foothills with high clastic input is strongly diluted compared to regions in the eastern 
basin where bonebeds develop. In this study the BFSM and the overlying FB allomember are present at the Moberly Lake Road (figure 27) and the Deadhorse Meadows outcrops (figure 9). The FSMB in the Moberly Lake Road section is a pebble conglomerate with a high gamma ray signal immediately above, but poor in phosphatic debris. At Deadhorse Meadows this horizon is a medium grained sandstone containing abundant plant debris. Fish scales are a visible component throughout this interval. Immediately above the BFSM both sections are fine grained mudstones with no bioturbation or foraminifera.

The widespread disappearance of all foraminifera at the end of the Albian requires an explanation. Previous authors have hypothesized a stratified water column that is established through the Early Cenomanian sea-level rise by bringing Tethyan and Boreal derived watermasses together (Hay, 1989; Hay et al., 1993). The difficulty with this theory is the lack of typical pelagic Tethyan derived microfossils in these early Cenomanian deposits (Schröder-Adams et al., 1996). It also has been suggested that episodes of widespread anoxia are typically associated with transgressions resulting in an increased influx of organic matter such as refractory wood and plant material. During the early Cenomanian the northern portion of the Western Interior Sea does not show evidence for pelagic organic carbon. Nannofossils and planktic foraminifera only entered during late Cenomanian/Turonian time when Tethyan waters became more prevalent in the North (Bloch et al., 1999). Diverse dinoflagellate communities in surface waters, however, survived the Albian/Cenomanian boundary suggesting that surface waters remained productive during deposition of the Lower Cenomanian Fish Scales Formation (Bloch et al., 1999). Hydrogen Index values vary depending on localities indicating a mixed source of organic matter with mainly terrestrial derived organic matter in the northwest (Bloch et al., 1999) close to the study area. In any case, decomposition of this 
increased amount of organic matter through bacterial oxidation caused oxygen depleted waters (Kauffman, 1981; Hallam, 1992; Wignall, 1994). Where this oxygen minimum zone reaches the sediment/water interface the benthic community will be negatively affected (Jenkyns, 1980). Leckie et al. (1992) found abundant amorphous organic matter above the FSMB, which has been linked to marine transgression and anoxic bottom waters. Algal cysts are abundant within the FB allomember, and commonly occur in organic-rich marine shales, deposited under anoxic conditions (Leckie et al., 1992). Black, bituminous shales are globally widespread throughout Cretaceous oceans. These stem from oceanic anoxic events that were short-lived periods of increased organic carbon burial, measured in distinct carbon isotope excursions (e.g. Jenkyns, 1980; Leckie et al., 2002 and references therein). Figure 51 roughly positions the Cretaceous lithostratigraphic units of the western margin of the Canadian Western Interior Sea onto a Cretaceous timescale comparing formational boundaries to eustatic sea-level cycles and variations in $\delta^{13} \mathrm{C}$. The loss of all benthic foraminifera at the Albian-Cenomanian boundary in the Western Interior Sea, dated at $98-99 \mathrm{Ma}$ (Obradovich, 1993) just falls slightly later than the Anoxic Event OAE1d, also called the Breistroffer Event (figure 51). This oceanic anoxic event developed mainly in the eastern and western Tethys approximately $99.5 \mathrm{Ma}$ ago (Leckie et al., 2002). It is believed to be triggered by a series of events such as tectonics, global warming, rising sea level, resulting in flooding of coastal plain areas, changes in ocean circulation and increasing watermass stratification. These extraordinary changes continued throughout the Upper Cretaceous and culminated in the globally spread OAE2 (Bonarelli event) marking the Cenomanian/Turonian boundary. Cretaceous open oceanic sediments such as deposited in the Tethyan Ocean were rich in pelagic carbonate, which differs to the Western Interior Sea during 


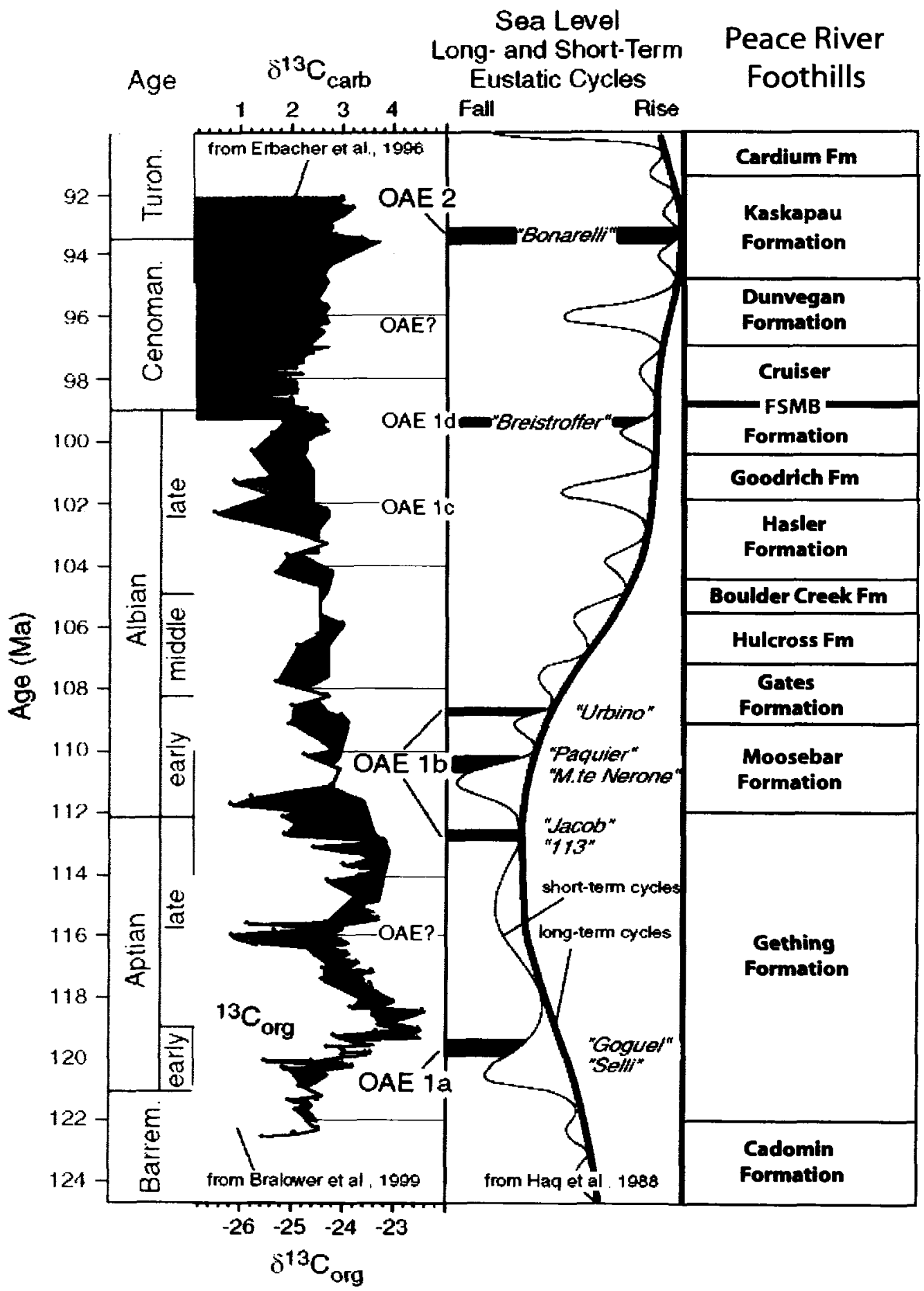

Figure 51. Summary of major geochemical, tectonic and sea level events associated with mid-Cretaceous oceanic anoxic events (OAEs) (from Leckie et al., 2002). Peace River foothills strata (Stott, 1982) showing the Fish Scale Marker Bed (FSMB) in comparison to global sea-level. 
Albian/early Cenomanian time where clastic sedimentation prevailed in a shallow foreland basin. Therefore, direct comparisons are difficult. Consequently, for the abovediscussed reasons rapid rising sea levels during early Cenomanian time flooding coastal areas rich with organic matter seems to be the most plausible explanation for the cause of depleted oxygen bottom waters in this epicontinental sea.

\section{Application beyond the study area}

In the studied outcrops foraminiferal assemblage changes have been shown to correlate with sequence stratigraphic units. This integration resulted in a newly proposed biostratigraphic framework. The question remains if this framework is useful when applied to subsurface strata further east in the basin, for example in forebulge areas where unconformities are common and in regions removed from the westerly derived sediment source. Recently, subsurface well log correlations have resulted in an allostratigraphic framework for the Cenomanian to Turonian interval for the Rocky Mountain Foothills to southwestern Saskatchewan (Tyagi et al., 2007). This demonstrates that allostratigraphic surfaces can be pulled from the foredeep east to condensed forebulge in Saskatchewan.

Figure 52 gives a rough comparison between the overall changes in numbers of agglutinated species of the Deadhorse Meadows section and well 11-36-22-1W2 in eastern Saskatchewan, which was studied by Schröder-Adams et al. (1996). While the interval of the Westgate and Belle Fourche formations in Saskatchewan are condensed to less than half the thickness of Deadhorse Meadows (allomembers WA to FC), broad similarities can be seen. The peak foraminiferal abundance in the western WA allomember has no representation further east as shown in the allostratigraphic framework (figure 46) and is not correlated here. Further up in the section, as one 


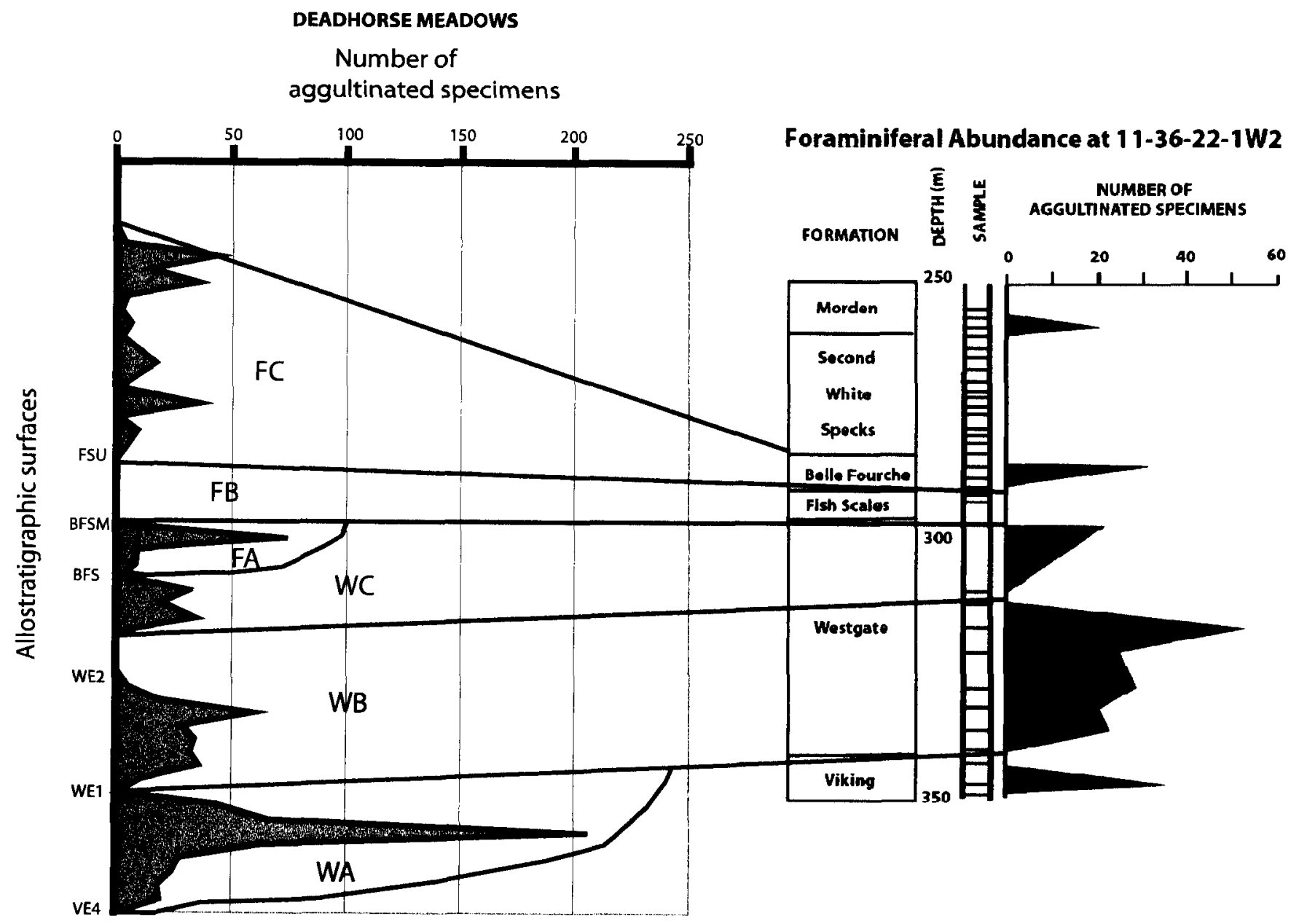

Figure 52. Possible correlation between the Deadhorse Meadows section and the 11-36-22-1W2 well in eastern Saskatchewan (from Schröder-Adams et al. 1996) using erosional surfaces and total number of aggultinated foraminifera. Allomembers are labled in black. 
observes abundance fluctuations associated with sequence boundaries (e.g. WE2) at Deadhorse Meadows, one can also detect those within the Westgate Formation in Saskatchewan. The widely recognized BFSM and its associated faunal change are clearly recorded in both localities. Final correlations between these patterns require further integration of allostratigraphic and micropaleontological work. Basin-wide correlative trends might suggest an eustatic signal that has influenced the Western Interior Sea (Plint and Kreitner, 2007) and its foraminiferal faunal development. 


\section{CONCLUSIONS}

Late Albian to Cenomanian strata in the Rocky Mountain foredeep were studied in seven outcrops addressing micropaleontology, lithostratigraphy and allostratigraphy. The following conclusions are drawn from this study:

1- The original foraminiferal zonation after Caldwell et al. (1993) for Northeastern British Columbia has been revised as a result of integration with recently developed regional allostratigraphic framework after Roca (2007). A new zonation of six foraminiferal zones has been proposed. These include in ascending order:

a) The Haplophragmoides multiplum Zone recognized in the VD allomember between the VE3 and VE4 surfaces.

b) The Haplophragmoides postis goodrichi Zone is present only in the northern portion of the study area in the WA allomember between the VE4 and WE1 surfaces.

c) The Trochammina umiatensis Zone is recognized in the WB allomember between the WE1 and WE2 surfaces.

d) The Haplophragmium swareni Zone is present in the WC and FA allomembers between the WE2 and FSMB surfaces.

e) The Verneuilina canadensis Zone is recognized in the southern portion of the study area in the WB and WC allomembers between the WE1 and FSMB surfaces.

f) The Verneuilinoides perplexus Zone which lies outside the allostratigraphic framework of Roca (2007) and Zhang (2006) follows the original zonation created by Caldwell et al. $(1978,1993)$ and contains both the Ammobaculites gravenori and Gaudryina irenensis subzones. 
2- The new zonal indicators are chosen for their laterally consistent occurrence within their retrospective allomember, their short biostratigraphic range and their easily recognizable morphology.

3- The allostratigraphic framework for Albian-Cenomanian strata created by Roca (2007) and Zhang (2006) in western Alberta has been extended to northeastern British Columbia in order to integrate studied outcrops. Log correlations to the Peace River area of British Columbia indicate an overestimation in the previously assumed thickness of the Hasler Formation.

4- Foraminiferal assemblage changes correlate with allostratigraphic erosional surfaces throughout the study area and new zonations coincide with allomembers.

5- The FB allomember represents the lowest Cenomanian and is barren of foraminifera. The interval represents an anoxic event possibly due to rapid transgression resulting in increased input of organic matter extending the oxygen minimum zone.

6- The reference section at Deadhorse Meadows preserves mainly HST/FSST. All sequences show relatively low species richness with peak abundances occurring in the middle of the sequence.

7. Vertical and lateral distribution of foraminiferal morphotypes correlate to sedimentary facies developments, paleosalinities and paleoshoreline positions making them useful paleoenvironmental indicators. Albian sediments and their faunal communities represent lower shoreface to marginal marine settings. Deepening to lower offshore settings takes place above the BFSM within the lowest Cenomanian associated with the Greenhorn transgression. 
8- Close integration of biostratigraphic boundaries and faunal changes with allostratigraphy has resulted in refined positions of erosional surfaces that had the most impact on the paleoecological setting and with that the recognition of system tracts. 


\title{
SYSTEMATICS
}

Each species is listed with its original reference in addition to one, often more recent publication that figures the species. Species occurrences are based on lithostratigrapic units and allomembers after Roca (2007).

\section{AGGULTINATED FORAMINIFERA}

\author{
Family ASTRORHIZIDAE Brady, 1881 \\ Genus Bathysiphon M. Sars in G. O. Sars, 1872 \\ Bathysiphon brosgei Tappan, 1957 \\ Plate 1, figures 1,2
}

Bathysiphon brosgei Tappan, 1957. United States National Museum, Bulletin no. 215, p. 202, pl. 65, figs. $1-5$.

Bathysiphon brosgei Tappan, Stelck and Koke, 1987, Canadian Journal of Earth Sciences v. 24 , pl. 1, figs. 1-3.

Occurrence. This species is recognized in the Hasler, Goodrich and Cruiser formations of the Ft. St. John Group of northwestern Alberta and northeastern British Columbia. In central Alberta it occurs in the Joli Fou, Viking and Westgate formations of the Colorado Group. In this study it is recognized in allomembers VD, WA, WB, WC and FA after (Roca, 2007). B. brosgei was originally described from the Topagoruk and Fortress Mountain formations of Alaska.

Family SACCAMMINIDAE Brady, 1884

Genus Psammosphaera Schultze, 1875 


\section{Psammospaera sp.}

Plate 1, figure 3

Saccammina alexanderi (Loeblich and Tappan), 1950

Plate 1, figure 4

Porteonina alexanderi Loeblich and Tappan, 1950. University of Kansas Paleontological Contributions, Protozoa, art. 3, p. 5, pl. 1, figs. 1, 2.

Saccammina alexanderi (Loeblich and Tappan), Eicher, 1960, Peabody Museum of

Natural History, Bulletin, no. 15, p. 55, pl. 3, figs. 1, 2.

Occurrence. This species is recognized in the Moosebar, Hasler, Goodrich and Cruiser formations of the Ft. St. John Group of northwestern Alberta and northeastern British Columbia. In central Alberta it occurs in the Joli Fou, Viking and Westgate formations of the Colorado Group. It is recognized in allomembers VD, WA, WB, WC and FA after (Roca, 2007). S. alexanderi was originally described from the Lower Cretaceous Kiowa Shale, of Kansas.

\section{Saccammina globosa Crespin, 1963}

Plate 1, figure 5

Saccammina globosa Crespin, 1963. Australia, Department of Natural Development, Bureau of Mineral Resources, Geology and Geophysics, Bulletin 66, p. 21, pl. 1 figs. 13-17.

Occurrence. This species is recognized in the Hasler Formation of the Ft. St. John Group of northwestern Alberta and northeastern British Columbia. In central Alberta it occurs in the Westgate Formation of the Colorado Group. It is 
recognized in allomembers VD, WA and WB after (Roca, 2007). S. globosa was originally described from the Cretaceous of Australia.

Remarks. The globular shape of S. globosa separates it from S. alexanderi.

Family AMMODISCIDAE Ruess, 1862

Genus Ammodiscus Reuss, 1862

Ammodiscus mangusi Tappan, 1957

Plate 1, figure 6

Ammodiscus mangusi Tappan, 1957, United States National Museum, Bulletin no. 215, p. 203, pl. 65, figs. 15-14.

Ammodiscus mangusi Tappan, Koke and Stelck, 1985, Canadian Journal of Earth Sciences v. 22, pl. 1, figs. 20-21.

Occurrence. This species is recognized in the upper Hasler Formation of the Ft. St. John Group of northwestern Alberta and northeastern British Columbia. It is recognized in allomember WB after (Roca, 2007). A. mangusi was originally described in the Topagoruk and Fortress Mountain formations of Alaska

Family HORMOSINIDAE Haeckel, 1894

Genus Reophax de Montfort, 1808

Reophax minuta Tappan, 1940

Plate 1, figures 7,8

Reophax minuta Tappan 1940, Journal of Paleontology. v. 14, p. 94, pl. 14, fig 4.

Reophax minuta Tappan, Stelck and Hedinger 1983, Canadian Journal of Earth Sciences v. 20 , no. 8 , p. 1248-1259, pl. 1, fig. 17-18. 
Occurrence. This species is recognized in the Hasler and Goodrich formations of the Ft. St. John Group of northwestern Alberta and northeastern British Columbia. In central Alberta it occurs in the Westgate Formation of the Colorado Group. It is recognized in allomembers WB, WC and FA after (Roca, 2007). $R$. minuta was originally described from the Lower Cretaceous Washita Group.

Reophax texanus Cushman and Waters, 1928

Plate 1, figure 9

Reophax texanus Cushman and Waters, 1928, Journal of Paleontology, vol. 2, no. 4, p 367 , pl. 1, fig 9-11.

Reophax texanus Cushman and Waters, Stelck and Hedinger 1983, Canadian Journal of Earth Sciences v. 20, no. 8, p 1248-1259, pl. 1, fig. 7.

Occurrence. This species is recognized in the Hasler Formation of the Ft. St. John Group of northwestern Alberta and northeastern British Columbia. It is recognized in allomember WC after (Roca, 2007). R. texanus was originally described in the Cisco Group Sutton County, Texas.

Reophax troyeri Tappan, 1960

Plate 1, figures 10,11

Reophax troyeri Tappan, 1960, American Association of Petroleum Geologists Bulletin, v. 44 , no. 3 , p. 291 , pl. 1, figs. 10-12.

Reophax troyeri Tappan, Koke and Stelck, 1985, Canadian Journal of Earth Sciences v. 22, pl. 1, figs. $20-24$. 
Occurrence. This species occurs in the Hasler, Goodrich formations of the Ft. St. John Group of northwestern Alberta and northeastern British Columbia. In central Alberta it occurs in the Joli Fou and Westgate formations of the Colorado Group. It is recognized in allomembers VD, WA, WB, WC and FA after (Roca, 2007). This tason was originally described from the Middle Albian Topagoruk Formation, northern Alaska.

Remarks. This species has a small to medium test with a very distinct neck. It can be readily distinguished from Ammobaculites fragmentarius by its smaller size and more uniform test.

Reophax vasiformis Chamney, 1978

Plate 1 , figures 12,13

Reophax vasiformis Chamney, 1978, Geological Survey of Canada, Bulletin 253, p. 10 11 , pl. 1, figs. 12-14.

Reophax vasiformis Chamney, Koke and Stelck, 1985, Canadian Journal of Earth Sciences v. 22, pl. 1, figs. 17-19.

Occurrence. This species is recognized in the Hasler and Goodrich formations of the Ft. St. John Group of northwestern Alberta and northeastern British Columbia. In central Alberta it occurs in the Joli Fou and Westgate formations of the Colorado Group. It is recognized in allomembers VD, WA, WB after (Roca, 2007).

This species was originally described from the Middle to Upper Albian Arctic Red Formation, Yukon Territory.

Family RZEHAKINIDAE Cushman, 1933

Genus Miliammina Heron-Allen and Earland, 1930 
Miliammina manitobensis Wickenden, 1932

Plate 1, figures 16-19

Miliammina manitobensis Wickenden, 1932, Royal Society of Canada Transcations, $3^{\text {rd }}$ Serial, v. 26, sec. 4. p. 90 , pl. 1 figs. 11 a-c.

Miliammina manitobensis Wickenden, North and Caldwell, 1975a, Geological Survey of Canada Paper 74-38, pl. 1, figs. 12a-14b.

Occurrence. This species occurs in the Moosebar, Harmon, Hasler and Goodrich formations of the Ft. St. John Group of northwestern Alberta and northeastern British Columbia. In central Alberta it occurs in the Joli Fou and Westgate formations of the Colorado Group. It is recognized in allomembers VD, WA, WB, WC and FA from (Roca, 2007). M. manitobensis was originally described from the Upper Albian Ashville Formation in Manitoba, and later was recognized by Nauss (1947) in the Lower Albian Loydminster Formation in central Alberta.

Remarks. M. manitobensis is very common throughout the Albian across the entire basin. The test varies gradationally from elongate to oval. The aperture in some specimens is formed by the end of the final tubular chamber; in others, the chamber is constricted at or near its end to form a neck, variable in length.

\section{Miliammina sproulei Nauss, 1947}

Plate 2, figures 1, 2

Miliammina sproulei Nauss, 1947, Journal of Paleontology v. 21, no. 4, p. 339, pl. 48, figs. 13a-b.

Miliammina sproulei Nauss, Koke and Stelck, 1985, Canadian Journal of Earth Sciences v. 22 , pl. 2 , figs. $2,3,7,8$. 
Occurrence. This species occurs in the Moosebar, Harmon, Hasler and Goodrich formations of the Ft. St. John Group of northwestern Alberta and northeastern British Columbia. In central Alberta it occurs in the Joli Fou and Westgate formations of the Colorado Group. It is recognized in allomembers VD, WA and WB after (Roca, 2007). M. sproulei was originally recorded in the Lower Albian Cummings Formation in the Vermilion area of Alberta.

Remarks. The narrow elongate test distinguishes $M$. sproulei from $M$. manitobensis

Genus Psamminopelta Tappan, 1957

Genus Psamminopelta bowsheri Tappan, 1957

Plate 2, figure 3

Genus Psamminopelta bowsheri Tappan, 1957, United States National Museum, Bulletin no. 215 , p. 211 , pl. 67 , figs. $11-18$.

Genus Psamminopelta bowsheri Tappan, Sutherland and Stelck, 1972, Bulletin of Canadian Petroleum Geology, v. 20, no. 3, p. 566-567, pl. 2, figs. 14-17, pl. 3, figs. 1-4.

Occurrence. This species occurs in the Hasler, Goodrich and Cruiser formations of the Ft. St. John Group of northwestern Alberta and northeastern British Columbia. In central Alberta it occurs in the Joli Fou and Westgate formations of the Colorado Group. It is recognized in allomembers VD, WA, WB, WC and FA after (Roca, 2007). P. bowsheri was originally reported from the northern Alaskan Albian succession of the Torok, Tuktu, Topagoruk and Grandstand formations. 
Remarks. The paratypes encompassed a wide range of sizes. Specimens of this study also vary in size and are ovate to lenticular.

Family LITUOLIDAE de Blainville, 1825

Genus Haplophragmoides Cushman, 1910

Haplophragmoides collyra Nauss, 1947

Plate 2, figures 4, 5

Haplophragmoides collyra Nauss, 1947, Journal of Paleontology v. 21, p. 337, pl. 49, figs. 2,5 .

Haplophragmoides collyra Nauss, Koke and Stelck, 1985, Canadian Journal of Earth Sciences v. 22, p. 1248-1259, pl. 2, figs. 34-36.

Occurrence. This species is recognized in the Cruiser Formation of the Ft. St. John Group of northwestern Alberta and northeastern British Columbia. H. collyra was first described in the Late Cretaceous Lloydminster shale.

Haplophragmoides gigas Cushman, 1927

Plate 2, figures 6,7

Haplophragmoides gigas Cushman, 1927, Royal Society of Canada, Transactions ser. 3, v. 21 , pl. 2 , p. 129 , fig. 5 .

Haplophragmoides gigas Cushman, Stelck and Koke, 1986, Canadian Journal of Earth Sciences v. 24, p. 2254-2278, pl. 3, figs 5-6.

Occurrence. This species is recognized in the Hasler Formation of the Ft. St. John Group of northwestern Alberta and northeastern British Columbia. In central Alberta it occurs in the Joli Fou and Westgate formations of the Colorado Group. It is 
recognized in allomember VD from (Roca, 2007). H. gigas was first found in the upper Cretaceous in the British Petroleum Well No. \#13 at 1921-1929 feet interval.

Remarks. This species is known to have a wide range in size.

Haplophragmoides gilberti Eicher, 1965

Plate 2, figures 8,9

Haplophragmoides gilberti Eicher, 1965, Journal of Paleontology v. 39, no. 5, p. 894, pl. 103, figs. $11,13,14$.

Haplophragmoides gilberti Eicher, Sutherland and Stelck, 1972, Bulletin of Canadian Petroleum Geology, v. 20, p. 567-568, pl. 3, figs, 8-9.

Occurrence. This species is recognized in the Hasler Formation of the Ft. St. John Group of northwestern Alberta and northeastern British Columbia. In central Alberta it occurs in the Joli Fou and Westgate formations of the Colorado Group. It is recognized in allomember WA after (Roca, 2007). H. gilberti was originally described from the Cenomanian Graneros shale in Colorado.

Haplophragmoides kirki Wickenden, 1932

Plate 2, figures 10,11

Haplophragmoides kirki Wickenden, 1932, Transactions of the Royal Society of Canada, ser. 3 , v. 26. sec. 4 , p. 85 , pl. 1 figs. 1 a-c.

Haplophragmoides kirki Wickenden, McNeil and Caldwell, 1981, Geological Association of Canada, Special Paper no. 21, p. 152, pl. 11, figs. 10a-b. 
Occurrence. This species is recognized in the Cruiser Formation of the Ft. St. John Group of northwestern Alberta and northeastern British Columbia. In central Alberta it occurs in the Belle Fourche Formation of the Colorado Group. H. kirki was originally described from the Campanian Bearpaw Formation in Alberta

\section{Haplophragmoides linki Nauss, 1947}

Plate 2, figures 12,13

Haplophragmoides linki Nauss, 1947, Journal of Paleontology, v. 21, no. 4, p. 339, pl. 49 , figs. 7 a, b.

Haplophragmoides linki Nauss, North and Caldwell, 1975a, Geological Survey of Canada Paper 74-38 pl. 1, figs. 17a, b.

Occurrence. This species occurs in the Moosebar, Harmon, Hasler, Goodrich and Cruiser formations of the Ft. St. John Group of northwestern Alberta and northeastern British Columbia. In central Alberta it occurs in the Joli Fou and Westgate formations of the Colorado Group. It is recognized in allomembers VD, WA, WB, WC after (Roca, 2007). H. linki was originally described from the Lloydminster Member of the Cantaur Formation in the Vermilion area of Alberta.

Haplophragmoides multiplum Stelck and Wall, 1956

Plate 2, figures $14-17$

Haplophragmoides multiplum Stelck and Wall, in Stelck et al., 1956, Research Council of Alberta, Report no. 75, p. 37-38,pl. 4, figs. 14-16. 
Haplophragmoides multiplum Stelck and Wall, Eicher, 1960, Peabody Museum of Natural History, Bulletin, no. 15, p. 58-59, pl. 3, fig. 12.

Occurrence. This species occurs in the Harmon and Hasler formations of the Ft. St. John Group of northwestern Alberta and northeastern British Columbia. In central Alberta it occurs in the Joli Fou Formation of the Colorado Group. It is recognized in allomember VD after (Roca, 2007). H. multiplum was originally described from the Harmon Formation of northeastern British Columbia.

Remarks. H. multiplum makes a good indicator for the VD allomember because it is easily recognized, has a short range and is abundant in the VD allomember. $H$. multiplum is easily recognized by its small, planispiral test, with at least three whorls of chambers with twelve in the ultimate whorl. H. multiplum is a subzonal marker in the Albian Gaudryina nanushukensis Zone (Caldwell et al., 1978, 1993) in the Harmon/Hulcross Formation. Its presence in the VD allomember (Viking Formation) and paucity above it make it a good indicator for the VD allomember.

Haplophragmoides postis Stelck and Wall, 1956

Plate 2, figures 18-21; Plate 3, 1-4

Haplophragmoides postis Stelck and Wall, in Stelck et al., 1956, Research Council of Alberta, Report no. 75 , p. 38, pl. 4, figs. 23-24.

Haplophragmoides postis Stelck and Wall, Koke and Stelck, 1985, Canadian Journal of Earth Sciences v. 22, pl. 2, figs. 15-21, 26-30.

Occurrence. This species occurs in the Hasler, Goodrich and Cruiser formations of the Ft. St. John Group of northwestern Alberta and northeastern British Columbia. In central Alberta it occurs in the Joli Fou and Westgate formations of the Colorado 
Group. It is recognized in allomembers VD, WA, WB, WC and FA after (Roca, 2007). H. postis was originally reported from the Early Albian Gates Formation of northeastern British Columbia, but has since been recognized in the Upper Albian.

Remarks. A lot of variability exists within $H$. postis. Sutures are distinct and range from nearly straight to slightly sigmoidal. Seven to ten chambers are usually visible in the ultimate whorl. This species can be distinguished by medium sized tests that are evolute with chambers that are approximately the same size.

Haplophragmoides postis goodrichi Sutherland and Stelck, 1972

Plate 3, figures 5, 6

Haplophragmoides postis goodrichi Sutherland and Stelck, 1972, Bulletin of Canadian Petroleum Geology, p. 570, pl. 3, figures 13-15.

Occurrence. This species is recognized in the Hasler Formation of the Ft. St. John Group of northwestern Alberta and northeastern British Columbia. It is recognized in allomember WA after (Roca, 2007). H. postis goodrichi was originally described from the Upper Albian Goodrich Formation of northeastern British Columbia.

Remarks. $H$. postis goodrichi differs from $H$. postis by being less evolute and having strongly inflated chambers that increase rapidly in size. The number of chambers varies form seven to ten in the ultimate whorl with two to two and a half whorls being visible. This species makes a good indicator for the WA allomember because it is easily identifiable and only occurs in the WA allomember. It also occurs in great numbers especially in near nearshore deposits. 
Haplophragmoides topagorukensis Tappan, 1957

Plate 3, figures 7, 8

Haplophragmoides topagorukensis Tappan, 1957, United States National Museum, Bulletin 215, pl. 203, pl. 65, figs. 15-25.

Haplophragmoides topagorukensis Tappan, Sutherland and Stelck, 1972, Bulletin of Canadian Petroleum Geology, p. 570-571, pl. 3, figs. 10-12.

Occurrence. This species is recognized in the Hasler Formation of the Ft. St. John Group of northwestern Alberta and northeastern British Columbia. In central Alberta it occurs in the Westgate Formation of the Colorado Group. It is recognized in allomember WC after (Roca, 2007). H. topagorukensis was originally described from the Albian Torok, Topagoruk, and Grandstand formations in northern Alaska.

Genus Haplophragmium Reuss, 1860

Haplophragmium swareni Stelck and Hedinger, 1976

Plate 4, figures 7,8

Haplophragmium swareni Stelck and Hedinger, 1976, Journal of Foraminiferal Research, vol 6, no. 2, p. 137, pl. 1, figs 8-11.

Occurrence. This species is recognized in the Goodrich Formation of the Ft. St. John Group of northwestern Alberta and northeastern British Columbia. It is recognized in allomembers WC and FA after (Roca, 2007). H. swareni was originally described from the Sully Formation on the Sikanni Chief River in northeastern British Columbia and has been extended by Schröder-Adams and Pedersen (2003) into the Buckinghorse Formation. 
Remarks. H. swareni is used as an indicator species for the Haplophragmium swareni Zone (allomembers WC and FA). This species occurs only in this interval and is easily identified. It consists of a streptospirally or trochospirally coiled portion (6-10 chambers) and a later rectilinear portion with 5 or 6 chambers.

Genus Ammobaculites Cushman, 1910 Ammobaculites fragmentarius Cushman, 1927

Plate 3, figures 11-14

Ammobaculites fragmentarius Cushman, 1927a, Royal Society of Canada Transactions, $3^{\mathrm{RD}}$ serial, v. 21 , sec. 4 , p. 130 , pl. 1 , fig. 8 .

Ammobaculites fragmentarius Cushman, Stelck, Wall, Bahan, and Martin, 1956, Alberta Research Council Report no. 75, p. 21-22, pl. 5, figs. 18-19.

Occurrence. This species is recognized in the Hasler, Goodrich and Cruiser formations of the Ft. St. John Group of northwestern Alberta and northeastern British Columbia. In central Alberta it occurs in the Joli Fou and Westgate formations of the Colorado Group. It is recognized in allomembers VD, WA, WB, WC and FA after (Roca, 2007). A. fragmentarius was originally described from unnamed Cretaceous rocks of Alberta.

Remarks. This species is easily distinguished by its tapering nature in the uniserial portion of the test. A. fragmentarius is common throughout the entire Albian in the Western Interior.

Ammobaculites gravenori Stelck and Wall, 1955 
Plate 3, figures 9,10

Ammobaculites gravenori Stelck and Wall, 1955, Research Council Report., Edmonton, Alberta, no. 68, p 65, pl. 1, figs 1-3.

Occurrence. This species is recognized in the Cruiser Formation of the Ft. St. John Group of northwestern Alberta and northeastern British Columbia. A. gravenori was first described from the Imperial Oil Limited Spirit River test hole A-337-1 in the Kaskapau Formation

Remarks. This species is similar to $A$. tyrrelli but is distinguished by having a more involute coiled portion. It is also a subzonal marker in the Verneuilinoides perplexus Zone of Caldwell et al., (1978, 1993).

Ammobaculites petilus Eicher, 1960

Plate 3, figure 15,16

Ammobaculites petilus Eicher, 1960, Peabody Museum of Natural History, Bulletin 15, p. 62-63, pl. 4, figs. 2a, b, 6 .

Ammobaculites petilus Eicher, North and Caldwell, 1975a, Geological Survey of Canada Paper 74-38, pl. 2, figs. 6, 7.

Occurrence. This species occurs in the Cruiser Formation of the Ft. St. John Group of northwestern Alberta and northeastern British Columbia. In central Alberta it occurs in the Belle Fourche Formation of the Colorado Group. It is recognized in allomembers WA and WB after (Roca, 2007). A petilus was originally described from the Upper Albian Thermopolis Shale, Wyoming.

Remarks. A petilus differs from A. tyrrelli principally in being much more slender with less inflated chambers and having a smaller coil often with more chambers. 
Ammobaculties tyrrelli Nauss, 1947

Plate 3 , figures 17,18 ; Plate 4, figures 1,2

Ammobaculties tyrrelli Nauss, 1947, Journal of Paleontology v. 21, no 4, p. 333, pl. 48, fig. 2 .

Ammobaculties tyrrelli Stelck and Wall, in Stelck et al., 1956, Research Council of Alberta Report no. 75, p. 23, pl. 5, fig. 20.

Occurrence. This species occurs in the Hasler and Goodrich formations of the Ft. St. John Group of northwestern Alberta and northeastern British Columbia. In central Alberta it occurs in the Joli Fou and Westgate formations of the Colorado Group. It is recognized in allomembers VD, WA, WB, WC and FA after (Roca, 2007). A.tyrrelli (sensu stricto) was originally described from the Lloydminster Shale in the Vermilion area of Alberta.

Remarks. I include Ammobaculites tyrrelli jolifouensis Stelck and Wall in this category as the specimens quite closely resemble $A$. tyrrelli. Also included in this category is $A$. humei Nauss which has a similar stratigraphic range. Nauss described the difference between A. tyrrelli and A. humei as the latter having more coarse grains in the test and a pyriform last chamber. These differences may be the result of differing substrates and preservation.

Ammobaculites wenonahae Tappan, 1960

Plate 4 , figures 3,4

Ammobaculites wenonahae Tappan, 1960, American Association of Petroleum Geologists Bulletin, v. 44, no. 3, p. 291. pl. 1, figs. 3-6. 
Ammobaculites wenonahae Tappan, Koke and Stelck, 1984, Canadian Society of Petroleum Geologists Memoir 9, pl. 1, figs. 33-35.

Occurrence. This species is recognized in the Hasler Formation of the Ft. St. John Group of northwestern Alberta and northeastern British Columbia. In central Alberta it occurs in the Joli Fou and Westgate formations of the Colorado Group. It is recognized in allomember VD after (Roca, 2007). A. wenonahae was initially described from the Middle Albian Topagoruk and Upper Albian Grandstand formations, northern Alaska.

Remarks. A. wenonahae differs from A. fragmentarius Cushman in being two to three times as large with chambers proportionally broader, lower and more closely appressed.

Family TEXTULARIOPSIDAE Loeblich and Tappan, 1982

Genus Textulariopsis Banner and Pereira, 1981

Textulariopsis minuta (Berthelin), 1880

Plate 4, figure 11

Textulariopsis minuta (Berthelin), Stelck and Hedinger, 1983, Canadian Journal of Earth Sciences v. 20, pl. 2, figs. 9-10.

Textulariopsis minuta (Berthelin), Stelck and Koke, 1987, Canadian Journal of Earth Sciences v. 24 , pl. 4 , figs. $26-27$.

Occurrence. This species occurs in the Hasler Formations of the Ft. St. John Group of northwestern Alberta and northeastern British Columbia. It is recognized in allomembers WA and WB after (Roca, 2007). 
Remarks. The original reference was unavailable for this species. T. minuta may have been placed originally in one of a number of genera including Textularia, Bigenerina or Vulvulina.

\author{
Family TROCHAMMINIDAE Schwager, 1877 \\ Genus Trochammina Parker and Jones, 1859 \\ Trochammina rutherfordi Stelck and Wall, 1955 \\ Plate 4, figures 12,13
}

Trochammina rutherfordi Stelck and Wall, 1955, Research Council of Alberta, Report no. 70 , p. 56-57, pl. 1, figs, 11-12.

Trochammina rutherfordi Stelck and Wall, North and Caldwell, 1975a, Geological Survey of Canada Paper 74-38, pl. 67, figs. 27-29.

Occurrence. This species was recognized in the Hasler, Goodrich and Cruiser formations of the Ft. St. John Group of northwestern Alberta and northeastern British Columbia. In central Alberta it occurs in the Westgate and Belle Fourche formations of the Colorado Group. It is recognized in allomembers VD and WA after (Roca, 2007). T. rutherfordi was originally described from the Cenomanian Kaskapau Formation in northwestern Alberta.

Remarks. T. rutherfordi can be recognized by its trochoid test with three whorls and six chambers in the ultimate whorl.

Trochammina umiatensis Tappan, 1957

Plate 4, figures 14,15 
Trochammina umiatensis Tappan, 1957, United States National Museum, Bulletin no. 215 , p. 214 , pl. 67 , figs. $27-29$.

Trochammina umiatensis Tappan, Sutherland and Stelck, 1972, Bulletin of Canadian Petroleum Geology v. 20, p. 575, pl. 5, figs. 1-4.

Occurrence. This species is recognized in the Hasler Formation of the Ft. St. John Group of northwestern Alberta and northeastern British Columbia. In central Alberta it occurs in the Westgate Formation of the Colorado Group. It is recognized in allomember WB after (Roca, 2007). T. umiatensis was originally described from the Upper Albian Grandstand Formation, northern Alaska.

Remarks. T. umiatensis is an indicator species of the Trochammina umiatensis Zone (allomember WB) and is easily recognized by having a trochoid test with chambers that are inflated and subglobular, few in number, increasing rapidly in size, and only four or five chambers in each whorl.

Family VERNEUILINIDAE Cushman, 1911

Genus Verneuilinoides Loeblich and Tappan, 1949

Verneuilinoides borealis Tappan, 1957

Plate 4, figure 16

Verneuilinoides borealis Tappan, 1957, United States National Museum, Bulletin no. 215 , p. 206 , pl. 66 , figs. $10-18$.

Verneuilinoides borealis Tappan, Sliter, 1981, Geological Survey of Canada Bulletin 300 , p. 57 , pl. 11 , figs. 11,16 .

Occurrence. This species is recognized in the Hasler Formation of the Ft. St. John Group of northwestern Alberta and northeastern British Columbia. In central Alberta it 
occurs in the Joli Fou and Westgate formations of the Colorado Group. It is recognized in allomember VD after (Roca, 2007). V. borealis was originally recognized in the Albian Torok, Topagoruk, and Grandstand formations, northern Alaska.

Remarks. This species is extremely variable in size, degree of flaring, and coarseness of texture

Verneuilinoides fischeri Tappan, 1957

Plate 4, figure 17,18

Verneuilinoides fischeri Tappan, 1957, U. S. National Museum Bulletin, Washington D. C., no. 215 , p. 145 , pl. 66 , figs $23-28$.

Occurrence. This species is recognized in the Hasler Formation of the Ft. St. John Group of northwestern Alberta and northeastern British Columbia. It is recognized in allomember VD from (Roca, 2007). V. fischeri was first described from the Upper Cretaceous Ignek formation, Alaska.

Verneuilinoides perplexus Stelck and Wall, 1955

Plate, 4 figures 19, 20

Verneuilinoides perplexus Stelck and Wall, 1955, Alberta Research Council, Report no. 68 , p. 10 pl. 2 , figs 40,41 .

Occurrence. This species is recognized in the Cruiser Formation of the Ft. St. John Group of northwestern Alberta and northeastern British Columbia. In central Alberta it occurs in the Belle Fourche Formation of the Colorado Group. $V$. 
perplexus was first described from the Upper Cretaceous, upper Cenomanian, lowermost part of the Kaskapau formation

Remarks. This species is a zonal marker in Caldwell et al., $(1978,1993)$ and this study. It is distinguished by having a triserial test with five volutions that increases rapidly in size with the final volution comprising at least one-third of the length of the test.

Genus Gaudryina d'Orbigny, 1839

Gaudryina canadensis Cushman, 1943

Plate 5, figure 1

Gaudryina canadensis Cushman, 1943, Contrib. Cushman Laboratory for Foraminiferal Research, v. 19, pt. 2, p. 28, pl. 6, figs. 7-8.

Gaudryina canadensis Cushman, McNeil and Caldwell, 1981, Geological Association of Canada Special Paper 21, p. 175, pl. 14, fig. 10-11.

Occurrence. This species is recognized in the Hasler and Goodrich formations of the Ft. St. John Group of northwestern Alberta and northeastern British Columbia. In central Alberta it occurs in the Joli Fou and Westgate formations of the Colorado Group. It is recognized in allomember WB and WC after (Roca, 2007). $G$. canadensis was originally described from the subsurface of Alberta.

Gaudryina irenensis Stelck and Wall, 1955

Plate 5, figures 2, 3

Gaudryina irenesis Stelck and Wall, 1955, Research Council of Alberta, Report 68, p. 208, pl. 66, figs. 19-22. 
Gaudryina irenesis Stelck and Wall, McNeil and Caldwell, 1981, Geological Association of Canada Special Paper 21, p. 177, pl. 14, figs. 8-9.

Occurrence. This species is recognized in the Cruiser Formation of the Ft. St. John Group of northwestern Alberta and northeastern British Columbia. G. irenensis was originally described upper Cenomanian in the lower part of the Kaskapau Formation.

Remarks. G. irenensis is a subzonal marker in the Verneuilinoides perlexus Zone of Caldwell et al., $(1978,1993)$. It is similar to $G$. hectori Nauss however, it was a stouter triserial portion and does not become biserial until rather late in its development.

Genus Verneuilina d'Orbigny, 1839

Verneuilina canadensis Cushman, 1927

Plate 5, figures 4-7

Verneuilina canadensis Cushman, 1927a, Transactions of the Royal Society of Canada ser. 3 , v. 21 , sec. 4 , p. 131 , pl. 1, fig. 11 .

Verneuilina canadensis Cushman, McNeil and Caldwell, 1981, Geological Association of Canada Special Paper 21, p. 175, pl. 14, fig. 3.

Occurrence. This species is recognized in the Hasler and Goodrich formations of the Ft. St. John Group of northwestern Alberta and northeastern British Columbia. In central Alberta it occurs in the Westgate Formation of the Colorado Group. It is recognized in allomembers WA, WB and WC after (Roca, 2007). V. canadensis was originally described from the subsurface of Alberta, uncertain formation. 
Remarks. V. canadensis has only been recorded from the Western Interior of North America. It is recognized as a subzonal marker in Caldwell et al., $(1978,1993)$ and as a zonal marker of the WB and WC allomembers in the southern portion of this study. This species makes a good indicator species due to its short biostratigraphic range, its ease of identification and abundance.

Family GLOBOTEXTULARIIDAE Cushman, 1927b

Genus Gravellina Brönnimann, 1933

Gravellina chamneyi Stelck, 1975

Plate 5, figures 8,9

Gravellina chamneyi Stelck, 1975, Geological Association of Canada Special Paper 13, p. 267-268, pl. 3, figs. $27,28,37-44$.

Gravellina chamneyi Stelck, Koke and Stelck, 1985, Canadian Journal of Earth Sciences v. 22 , pl. 4 , figs. $30,31,34-36$.

Occurrence. This species is recognized in the Hasler and Goodrich formations of the Ft. St. John Group of northwestern Alberta and northeastern British Columbia. In central Alberta it occurs in the Joli Fou and Westgate formations of the Colorado Group. It is recognized in allomembers WB and WC after (Roca, 2007). $G$. chamneyi was originally described from the upper Buckinghorse shale (Upper Albian) in northeastern British Columbia.

\section{CALCAREOUS FORAMINIFERA}

Family NODOSARIIDAE Ehrenberg, 1838

Genus Lenticulina Larmack, 1804 
Lenticulina macrodisca Tappan, 1960

Plate 5, figures 10,11

Lenticulina macrodisca Tappan, 1960, American Association of Petroleum

Geologists Bulletin vol. 44, no. 3, pl. 1 figs 16-19.

Lenticulina macrodisca Tappan, Stelck et al., 2000, Canadian Journal of Earth Science vol. 37 pl. 1, fig. 10.5 .

Occurrence. This species was only found I this study with a single occurrence. It appears in the Hasler Formation in the Deadhorse Meadows outcrop in British Columbia in allomember VD. Stelck, et al., 2000 found this species in the upper Viking of Giroux Lake, Alberta, a correlative stratigraphic interval to allomember VD. L. macrodisca was originally described from the Albian Topagoruk Formation in Alaska. 


\section{REFERENCES}

Abbott, S. T., and Carter, R. M., 1997. Macrofossil associations from mid-Pleistocene cyclothems in the Castlecliff section, New Zealand: Implications for sequence stratigraphy. Palaios, vol. 12, no. 2, p. 188-210.

Aberhan, M., 1994. Guild-structure and evolution of Mesozoic benthic shelf communities. Palaios, vol. 9, p. 516-545.

Banner, F. T. and Pereira, C. P.G., 1981. Some biserial and triserial agglutinated smaller foraminifera, their wall structure and its significance. Journal of Foraminiferal Research, 11. p. 85-117.

Baum, G.R., and Vail, P.R., 1988. Sequence stratigraphic concepts applied to Paleogene outcrop, Gulf and Atlantic basins. In: Wilgus, C.K., Hastings, B.S., St. C. Kendall, C.G., Posamentier, H.W., Ross, C.A., and Van Wagoner, J.C., (eds)., Sea-level changes: An integrated approach, Society of Economic Paleontologists and Mineralogists, Special Publication no. 42, p. 302-327.

Bennett, K . D., 1990. Milankovitch cycles and their effects on species in ecological and evolutionary time, Paleobiology, vol. 16, p. 579-607.

Berthelin, G., 1880. Mémoire sur les Foraminiféres fossils de l'étage Albien de Montcley (Doubs). Mémoire de la Sociétée Géologique de France, ser. 3, no.1, p. 1-84.

Berquist, H. R., 1966. Micropaleontology of the Mesozoic rocks of Northern Alaska. United States Geological Survey, Professional Paper 302-D, p. 93-227.

Blainville, H. M. Ducrotay de, 1825. Manuel de macologie et de conchyliologie (1827). Paris: F.G. Levrault.

Bloch, J., Schröder-Adams, C., Leckie, D. A., McIntyre, D.L., Craig, L. and Staniland, M., 1993. Revised stratigraphy of the lower Colorado Group (Albian to Turonian), Western Canada. Bulletin of Canadian Petroleum Geology, vol. 41. p. 325-348.

Bloch, J., Schröder-Adams, C., Leckie, D. A., McIntyre, D.L., Craig, L., 1999. Sedimentology, micropaleontology, geochemistry, and hydrocarbon potential of shale from the Cretaceous Lower Colorado Group in Western Canada. Geological Survey of Canada. Report: 531, $185 \mathrm{pp}$.

Boreen, T. and Walker, R. G., 1991. Definition of the allomembers and their facies assemblages in the Viking Formation, Willesden Green area, Alberta. Bulletin of Canadian Petroleum Geology, vol. 39, no. 2, p. 123-144. 
Boucott, A. J., 1990. Silurian and pre-Upper Devonian bio-events: in Kauffman, E. G., and Walliser, O. H., (eds)., Extinction events in earth history, Lecture notes in Earth Sciences, vol. 30: Springer-Verlag, Berlin, p. 5-30.

Brett, C. E., 1995. Sequence Stratigraphy, Biostratigraphy, and Taphonomy in Shallow Marine Environments, Palaios, vol. 10, p. 597-616.

Brett, C. E., 1998. Sequence Stratigraphy, Paleoecology, and Evolution: Biotic Clues and Responses to Sea-Level Fluctuations. Palaios, vol. 13, p. 241-262.

Brady, H. B., 1878. On the reticularian and radiolarian Rhizopoda (Foraminifera and Polycystina) of the North Polar Expedition 1875-76, Annals and Magazine of Natural History, ser. 5(1), p. 425-440.

Brady, H. B., 1881. Notes on some of the reticularian Rhizopoda of the Challenger expedition. Part III. 1. Classification. 2. Further notes on new species. 3. Note on Biloculina mud. Quaternary Journal of Microscopial Science, new ser. 21, p.3171.

Brady, H. B., 1884. Report on the foraminifera dredged by H. M. S. Challenger, during the years 1873-1876, in Report on the scientific results of the voyage of the H. M. S. Challenger during the years 1873-1876, Zoology, vol. 9

Caldwell, W.G.E., 1984. Early Cretaceous transgressions and regressions in the southern interior plains. In: D.D. Stott and D.J. Glass (eds), The Mesozoic of middle North America. Canadian Society of Petroleum Geologists Memoir, 9. p.173-203.

Caldwell, W.G.E., Diner, R., Eicher, D.L., Fowler, S.P., North, B.R., Stelck, C.R., and von Holdt Wilhelm, L., 1993. Foraminiferal Biostratigraphy of Cretaceous marine cyclothems. In: Caldwell, W.G.E., and E.G. Kauffman (eds), Evolution of the Western Interior Basin. Geological Association of Canada Special Paper, 39. p. 477-520.

Caldwell, W.G.E., North, B.R., Stelck, C.R. and Wall, J. H., 1978. A foraminiferal zone scheme for the Cretaceous system in the interior plains of Canada. In: C. R. Stelck and B.D.E. Chatterton, (eds), Western and Arctic Canadian Biostratigraphy. Geological Association of Canada Special Paper, 18, p. 495-575.

Cant, D., 1988. Regional structure and development of the Peace River Arch, Alberta: A Paleozoic failed rift system? Bulletin of Canadian Petroleum Geology, vol. 36, p. 284-295.

Carpenter, W. B., 1869. On the rhizopodal fauna of the deep sea. Proceedings of the Royal Society of London, $46 \mathrm{pp}$.

Carsey, D. O., 1926, Foraminifera of the Cretaceous of central Texas. University of Texas, Bulletin 2612, 56 pp. 
Chamney, T. P., 1969. Barremian Textularina, Foraminiferida from Lower Cretaceous beds, Goodenough Section, Aklavik Range, District of MacKenzie. Geological Survey of Canada, Bulletin 185, 41 pp.

Chamney, T. P., 1973. Microfauna of Gething Formation In: Stott, D. F., (ed), Lower Cretaceous Bullhead Group between Bullmoose Mountain and Tetsa River, Rocky Mountain Foothills, northeastern British Columbia. Geological Survey of Canada, Bulletin 219. p. 67-71.

Chamney, T. P. 1976. A morphological approach for paleoenvironmental interpretation of foraminifera; Albian of the Canadian Arctic. Bulletin of Canadian Petroleum Geology, vol. 25, no. 6, p. 1252.

Chamney, T. P., 1978. Albian foraminifera of the Yukon Territory. Geological Survey of Canada, Bulletin 253, $62 \mathrm{pp}$.

Chen, D., and Bergman, K., 1999. Stratal reorientation, depositional processes, and sequence evolution of the Cretaceous in the Peace River Arch region of the Western Canada Sedimentary Basin. Bulletin of Canadian Petroleum Geology, vol. 47, p. 594-620.

Clifton, H. E., 1986. Interpreting paleoenergy levels from sediment deposited on ancient wave-dominated shelves. In: Kinght, R. J. and McLean, J. R., (eds), Shelf Sands and Sandstones. Canadian Society of Petroleum Geologists, Memoir 11, p. 181191.

Culver, S., Woo, H. J., Oertel, G. F., and Buzas, M A., 1996. Foraminifera of coastal depositional environments, Virginia, U.S.A.: Distribution and taphonomy. Palaios, vol. 11, p. 459-486.

Crespin, I., 1963. Lower Cretaceous arenaceous Foraminifera of Australia. Australia, Department of Natural Development, Bureau of Mineral Resources, Geology and Geophysics, Bulletin 66, 69 pp.

Cushman, J. A., 1910. A monograph of the foraminifera of the North Pacific Ocean. Pt. 1. Astrohizidae and Lituolidae. Bulletin of the United States National Museum, vol. 71(1), p. 1-134.

Cushman, J. A., 1911. A monograph of the foraminifera of the North Pacific Ocean. Pt. 2.Textulariidae. Bulletin of the United States National Museum, vol. 71(2), p. 1108.

Cushman, J. A., 1927a. Some foraminifera from the Cretaceous of Canada. Transactions of the Royal Society of Canada, ser. 3, vol. 21, no. 4, p. 127-132. 
Cushman, J. A., 1927b. An outline of a re-classification of the foraminifera.

Contributions from the Cushman Laboratory for Foraminiferal Research, vol. 3. p. 1-105.

Cushman, J. A., 1933. Some new foraminiferal genera. Contributions from the Cushman Laboratory for Foraminiferal Research, vol. 9, p. 32-38.

Cushman, J. A., 1943. Gaudryina canadensis, new name. Contributions from the Cushman Laboratory for Foraminiferal Research, vol.19, no. 2. p. 27-28.

Dawson, G. M., 1870. On Foraminifera from the Gulf and River St. Lawrence. Canadian Naturalists, vol. 5. p. 172-177.

Defrance, J.L. M., 1824. Dictionaries des Science Naturelles, vol. 32, moll-morf. Strasbourg: F.G. Levrault, 86 pp.

Ehrenberg, C. G., 1838. Über dem blossen Auge unsichtbare Kalkthierchen und Kieselthierchen als Hauptbestandtheile der Kreidegebirge. Bericht über die zu Bekanntmachung geigneten Verhandlungen der Küöoniglichen Preussischen Akademie der Wissenschaften zu Berlin vol.1838, p. 192-200.

Eicher, D. L., 1960. Stratigraphy and micropaleontology of the Thermopolis Shale. Peabody Museum of Natural History, Bulletin 15, 126 pp.

Eicher, D. L., 1965. Foraminifera and biostratigraphy of the Graneros Shale. Journal of Paleontology, vol. 39. no. 5, p. 875-909.

Eicher, D. L., 1967. Foraminifera from the Belle Fourche shale and equivalents, Wyoming and Montana. Journal of Paleontology, vol. 41. no.1, p. 167-188.

Eicher, D. L., 1975. Cenomanian and Turonian foraminifera and paleoenvironments in the Big Bend region of Texas and Mexico. Geological Association of Canada, Special Paper no. 13, p. 277-301

Eicher, D. L., and Diner R., 1985. Foraminifera as indicators of water mass in the Cretaceous Greenhorn Sea, Western Interior. In: Pratt, L. M., Kauffman, E. G., and Zelt, F. B., (eds), Fine-grained deposits and biofacies of the Cretaceous Western Interior Seaway, evidence of cyclic sedimentary processes. SEPM Guidebook, vol. 4, p. 60-71.

Escalante, A. A. and Ayala, F. J., 1996. Molecular paleogenetics: the evolutionary history of Plasmodium and related protists. In: Jablonski, D., Erwind, D. H. and Lipps, J. H.., (eds), Evolutionary paleobiology, University of Chicago Press, 434 pp. 
Guliov, P., 1966. Two new middle Albian Foraminifera species from Saskatchewan. Contributions to the Cushman Foundations for Foraminiferal Research. vol.17. p. 142-143.

Guliov, P., 1967. Lower Cretaceous (Middle Albian) Albian Foraminifera species from Saskatchewan. Saskatchewan Department of Mineral Resources, Report 105. p. 340.

Haeckel, E., 1894. Systematische Phylogenie. Entwurf eines Naturlichen Systems der Organismen auf Grung ihrer Stammesgeschichte, Theil 1, Systematische Phylogenie der Protisten und Pflanzeb. Berlin: Georg Reimer.

Hallam, A., 1992. Phanerozoic sea-level changes. Columbia University Press. 435 pp.

Harrison, S. M., 1988. Albian foraminiferal biostratigraphy of a key borehole in northeastern British Columbia. University of Saskatchewan, M. Sc. Thesis, 99 pp.

Hay, W. W., 1989. Marginal seas as source of an oceanic oxygen minimum and origin of organic carbon-rich deposits. American Association of Petroleum Geologists. Bulletin 73, p. 362-376.

Hay, W.W., Eicher, D.L. and Diner, R., 1993. Physical oceanography and water masses in the Cretaceous Western Interior Seaway. In: Caldwell, W.G.E., and E.G. Kauffman, (eds), Evolution of the Western Interior Basin. Geological Association of Canada Special Paper, 39. p. 297-318.

Hein, F .J., Dean, M . E., Delure, A M., Grant, S K., Robb, G. and Logstaffe, F. J., 1986. The Viking Formation in the Caroline, Garrington and Harmattan East Fields, Western South-Central Alberta: sedimentology and paleogeography. Bulletin of Canadian Petroleum Geology, vol. 34, p. 91-110.

Hesse, R., 1984. Early diagenetic pore water/sediment interaction: Modern offshore basins. In: McIlreath, I. A., and Morrow, D. W., (eds), Diagenesis Geoscience Canada, p. 277-317.

Heron-Allen, E. and Earland, A., 1930. Some foraminifera from the South Atlantic: Pt. III. Miliammina, a new siliceous genus. Royal Microbiological Society of London, ser. 3, vol. 50, p. 38-45.

Holland, S.M., 1995. The stratigraphic distribution of fossils. Paleobiology, vol. 21. p. 92-109.

Holland, S. M. 1999. Were Paleozoic marine communities saturated with species? The influence of local and regional processes on local diversity of fossil assemblages. Abstracts with Programs, Geological Society of America, vol. 31, no. 7 p. 335. 
Jeletzky, J.A., 1968. Macrofossil Zones of the Marine Cretaceous of the Western Interior of Canada, and their correlation with the zones and stages of Europe and Western Interior of the United States. Geological Survey of Canada, Paper 67-72, p. 1-66.

Jeletzky, J. A., 1970. Cretaceous paleogeography of Arctic Canada. American Association of Petroleum Geologists Bulletin, vol. 54, no. 12, p. 2488-2497.

Jeletzky, J. A., 1971a. Marine Cretaceous biotic provinces and paleogeography of western and Arctic Canada: illustrated by a detailed study of ammonites: Geological Survey of Canada, Paper 70-22, 92 pp.

Jeletzky, J. A., 1971b. Biochronology of Jurassic-Cretaceous transition beds in Canada. Geological Survey of Canada, vol. 71-16, p. 1-8.

Jenkyns, H. C., 1980. Cretaceous anoxic events: from continents to oceans. Journal of Geological Society of London, vol. 137, Part 2, p. 171-188.

Jervey, M. T., 1992. Siliciclastic sequence development in foreland basins with examples from the Western Canadian Foreland Basin. In: R. W. Macqueen and D. A. Leckie, (eds), Foreland Basins and FoldbeltsTulsa, American Association of Petroleum Geologists Memoir 55, p. 9-14.

Jones, R. W. and Charnock, M. A., 1985. Morphogroups of agglutinated foraminifera: Their life positions and feeding habits and potential applicability in (paleo) ecological studies: Revue de Paléobiologié, vol. 4, p. 311-320.

Jowett, D. M. S., 2004. Paleoenvironments and regional correlations of AlbianCenomanian strata in the frontier Liard Basin of northwestern Canada. Carleton University. PhD. 411 pp.

Jowett, D. M. S., and Schröder-Adams, C. J., 2005. Paleoenvironments and regional stratigraphic framework of the middle-upper Albian Lepine Formation in the Liard Basin, northern Canada. Bulletin of Canadian Petroleum Geology, vol. 53, no. 1, p. $25-50$.

Kauffman, E.G., 1977. Geological and biological overview: Western Interior Cretaceous basin. The Mountain Geologist, vol.14, no. (3-4), p. 75-99.

Kauffman, E.G., 1981. A model for the generation of Cretaceous marine cyclothems in the Western Interior United States. Society of Economic Paleontologists, vol. 32, p. 1-4.

Kauffman, E.G., 1984. Paleobiogeography and evolutionary response in the Cretaceous western interior seaway of North America. In: G.E.G. Westermann, (ed), Jurassic-Cretaceous biochronology and paleogeography of North America. Geological Association of Canada Special Paper, 27 p. 273-306. 
Kauffman, E. G., and Caldwell, W. G. E., 1993. The Western Interior Basin in space and time. In: Caldwell, W G. E., and Kauffman, E. G., (eds), Evolution of the Western Interior Basin. Geological Association of Canada, Special Paper 39, p. 130 .

Kidwell, S.M., and Behrensmeyer, A.K., 1993. Taphonomic approaches to time resolution in fossil assemblages: Paleontological Society Short Course No. 6, Knoxville, $302 \mathrm{pp}$.

Koke, K.R., and Stelck, C.R., 1984. Foraminifera of the Stelckiceras Zone, basal Hasler Formation (Albian), northeastern British Columbia. Canadian Society of Petroleum Geologists, Memoir 9, p. 271-279.

Koke, K.R., and Stelck, C.R., 1985. Foraminifera of a Joli Fou Shale equivalent in the Lower Cretaceous (Albian), northeastern British Columbia. Canadian Journal of Earth Science, vol. 22, p. 1299-1313.

Kowalewski, M., Behrensmeyer, A. K., Fuersich, F. T., Gastaldo, R. A., Kidwell, S. M., Kosnik, M A., Plotnick, R. E., Rogers, R., and Alroy, J., 2002. Phanerozoic taphonomy of marine benthos: effects of skeletal durability on macroevolutionay trends. Abstracts with Programs. Geological Society of America, vol. 34, no. 6, p. 357.

Lamrack, J.B., 1804. Sutie des mémoires sur les fossils des environs de Paris. Annales Musée National d'Histoire Naturelle vol. 5, p. 179-188.

Leckie, D.A., Battacharya, J. P., Bloch, J., Gilboy, C. F. and Norris, B., 1994. Cretaceous Colorado/Alberta Group of the Western Canada Sedimentary Basin. In: Kramers, J. and Madunicky, M., (eds) Geological Atlas of the Western Canada Sedimentary Basin. Alberta Geological Survey. p. 335-352.

Leckie, D. A., Bloch, J., Singh, C., Wall, J. and Wilson, M., 1991. Shales of the Cretaceous Colorado Group in Western Canada: 1. What is the Fish Scale Marker Bed and can it produce hydrocarbons? Bulletin of Canadian Petroleum Geology, vol. 39 , no. $2,217 \mathrm{pp}$.

Leckie, D.A., Fox, C., and Tarnocai, C., 1989. Multiple paleosols of the late Albian Boulder Creek Formation, British Columbia, Canada. Sedimentology vol. 36, p. 307-323.

Leckie, D.A. and Reinson, G.E., 1993. Effects of middle to late Albian sea-level fluctuations in the Cretaceous Interior Seaway, Western Canada. In: Caldwell, W.G.E., and E.G. Kauffman (eds), Evolution of the Western Interior Basin. Geological Association of Canada Special Paper, 39, p. 119-129. 
Leckie, D.A. and Singh, C., 1991. Estuarine deposits of the Albian Pady Member (Peace River Formation) and lowermost Shaftesbury Formation, Alberta, Canada. Journal of Sedimentary Petrology, vol. 61, no. 5, p. 825-849.

Leckie, D.A. and Smith, D.G., 1992. Regional setting, evolution and depositional cycles of the Western Canadian Foreland Basin, In: R.W. Macqueen and D.A. Leckie (eds.), Foreland Basins and Foldbelts, American Association of Petroleum Geologists, Memoir 55, p. 9-46.

Leckie, D.A., Schroeder-Adams, C. J., Rosenthal, L. and Wall, J. H., 2000. An outcrop of the Albian Viking Formation and a southerly extension of the Hulcross/Harmon interval in west-central Alberta. Bulletin of Canadian Petroleum Geology, vol. 48, no. 1, p. $30-42$.

Leckie, D.A., Schroeder-Adams, C. J., Bloch, J. 2000. The effect of paleotopography on the late Albian and Cenomanian sea-level record of the Canadian Cretaceous interior seaway. Geological Society of America Bulletin, vol. 112, no. 8, p. 11791198.

Leckie, D.A., Staniland, M.R., and Hayes, B.J., 1990. Regional maps of the Albian Peace River and lower Shaftesbury formations on the Peace River Arch, northwestern Alberta and northeastern British Columbia. Bulletin of Canadian Petroleum Geology, vol. 38A, p. 176-189.

Leckie, D.A., Singh, C., Bloch, J., Wilson, M. and Wall, L., 1992. An anoxic event at the Albian-Cenomanian boundary: the Fish Scale Marker Bed, northern Alberta, Canada. Palaeogeography, Palaeoclimatology, Paleoecology, vol. 92, p. 139-166.

Leckie, R. M., Bralower, T. J. and Cashman, R. 2002. Oceanic anoxic events and plankton evolution; biotic response to tectonic forcing during the Mid-Cretaceous. Paleoceanography, vol. 17, no. 329 pp.

Loeblich, A. R. and Tappan, H., 1950. Foraminifera from the type Kiowa Shale, Lower Cretaceous, of Kansas. University of Kansas Paleontological contributions, Protozoa, art. vol. 3, p. 1-15.

Loeblich, A. R., 1946. Foraminifera from the type Pepper Shale of Texas. Journal of Paleontology, vol. 20, p. 130-139.

Loeblich, A. R. and Tappan, H., 1946, New Washita foraminifera. Journal of Paleontology, vol. 20, p. 238-258.

Loeblich, A. R. and Tappan, H., 1949. Foraminifera from the Walnut Formation (Lower Cretaceous) of northern Texas and southern Oklahoma. Journal of Paleontology vol. 23, p. 245-266. 
Loeblich, A. R. and Tappan, H., 1950. Foraminifera from the type Kiowa Shale, Lower Cretaceous, of Kansas. University of Kansas Paleontological contributions, Protozoa, art. vol. 3, p. 1-15.

Loeblich, A. R. and Tappan, H., 1964. Protista (2), Sarcodina. In: R. C. Moore, (ed), Treatise on Invertebrate Paleontology, pt. C. Geological Society of America and University of Kansas Press. p. 97-133.

Loeblich, A. R. and Tappan, H., 1982. A revision of Mid-Cretaceous textularian foraminifers from Texas. Journal of Micropaleontology, vol. 1, p. 55-69.

Loeblich, A. R. and Tappan, H., 1984. Some new porteinaceous and agglutinated genera of Foraminiferida. Journal of Paleontology vol. 58, p. 1158-1163.

Loeblich, A. R. and Tappan, H., 1987. Foraminiferal Genera and their Classification, (2 vol.). Van Nostrand Reinhold Company, New York, 2047 pp.

McNeil, D. H. and Caldwell, W. G. E., 1981. Cretaceous rocks and their Foraminifera in the Manitoba Escarpment. Geological Association of Canada Special Paper, 21, $439 \mathrm{pp}$.

McNeil, D. H., Issler, D. R. and Snowdon, L. R., 1996. Colour alteration, thermal maturity, and burial diagenesis in fossil foraminifers. Geological Survey of Canada, Report: 499, p. 34.

Mellon, G. B. and Wall, J. K., 1956. Foraminifera of the Upper McMurray and Basal Clearwater formations. Research Council of Alberta, Report 72, no.1, p. 5-29.

Mellon, G. B. and Wall, J. H., 1963. Correlation of the Blairmore Group and equivalent strata. Bulletin of Canadian Petroleum Geology, vol. 11, p. 396-409.

Monger, W. H., and Nokleberg, W. J., 1995. Evolution of the northern North American Cordillera: generation, fragmentation, displacement and accretion of successive North American plate-margin arcs. Geology and ore deposits of the American Cordillera, Geological Society of Nevada, p.1-20.

Montfort, P. Denys de, 1808. Conchyliologie Systématique et Classification Méthodique des Coquilles, vol. 1. Paris: F. Schoell. 52 pp.

Murray, J. W. and Alve, E., 1999. Taphonomic experiments on marginal marine foraminiferal assemblages: how much ecological information is preserved? Palaeogeography, palaeoclimatology, Palaeoecology, vol. 149, no. 1-4, p. 183197.

Nauss, A. W., 1945. Cretaceous stratigraphy of theVermilion area, Alberta, Canada. Journal of Paleontology, vol. 21, p. 329-343 
Nauss, A. W., 1947. Cretaceous microfossils of the Vermilion area, Alberta. American Association of Petroleum Geologists, Bulletin 29, p.1606-1629.

Nielsen, A. R. 1950. A microfaunal study of the Shaftesbury Formation. University of Alberta, Edmonton. Master's Thesis, 111 pp.

North American Commission of Stratigraphic Nomenclature [NACSN], 1983. North American Stratigraphic Code: American Association of Petroleum Geologists, Bulletin, vol. 67, p. 841-875.

North, B. R. and Caldwell, W. G. E., 1975a. Cretaceous foraminifera from Saskatchewan and Manitoba. Geological Survey of Canada, Paper 74-38 35pp.

North, B. R. and Caldwell, W. G. E., 1975b. Foraminifera faunas in the Cretaceous system of Saskatchewan. In: W. G. E. Caldwell, (ed), The Cretaceous System in the Western Interior of North America. Geological Association of Canada Special Paper, 13, p. 303-331.

Obradovich, J.D., 1993. A Cretaceous time scale. In: Caldwell, W.G.E., and E.G. Kauffman, (eds), Evolution of the Western Interior Basin. Geological Association of Canada Special Paper, 39, p. 379-396.

O'Connell, S. C., Dix, G. R. and Barclay, J. E., 1990. The origin, history and regional structural development of the Peace River Arch, Western Canada. Bulletin of Canadian Petroleum Geology, vol. 38A, p. 4-24.

Orbingy, A. d', 1826. Tableau méthodique de la classe des Céphalopodes. Annales des Sciences Naturelles vol. 7, p. 245-314.

Orbingy, A. d', 1839. Voyage dans l' Amérique méridionale - Foraminiféres, vol, 5(5), p. 1-86.

Patzkowski, M. E. and Holland, S. M., 1999. Biofacies replacement in a sequence stratigraphic framework: Middle and Upper Ordovician of the Hashville Dome, Tennessee, USA: Palaios, vol. 14, p. 301-323.

Posamentier, H.W., and Vail, P.R., 1988. Eustatic controls on clastic deposition II Sequence and systems tracts models. In: Wilgus, C.K., Hastings, B.S., St. C. Kendall, C.G., Posamentier, H.W., Ross, C.A., and Van Wagoner, J.C., (eds)., Sea-level changes: An integrated approach, Society of Economic Paleontologists and Mineralogists, Special Publication no. 42, p. 125-154.

Plint, G. A. and Kreitner, M. A., 2007. Extensive thins sequences spanning Cretaceous foredeep suggest high-frequency eustatic control: Late Cenomanian, Western Canada foreland basin. Geology, vol. 35. no. 8, p. 735-738. 
Price, L., 1964. Structure contours on Fish Scales marker horizons, northeastern British Columbia, and adjoining Alberta and Northwest Territories. Geological Survey of Canada. Preliminiary survey map, p. 57.

Price, R. A., 1994, Cordilleran tectonics and the evolution of the Western Canada Sedimentary Basin. In: (eds) Mossop, G. and Shetsen, I., Geological Atlas of the Western Canada Sedimentary Basin, p. 13-24.

Reuss, A. E., 1844. Geognostische Skizzen Aus Böhmen, Prague: C. W. Medau, vol. 2, p. $1-17$.

Reuss, A. E., 1862. Entwurf einer Systematischen Zusammenstellung der Foraminiferen. Sitzungsberichte der Kaiserlichen Akademie der Weissenschaften in Wien, Mathematisch-Naturwissenschaftliche Classe (1861) vol. 44(1), p. 355-396.

Rey J., Cubaynes, R., Qajoun, A., and Ruget, C., 1993. Foraminifera indicators of systems tracts and global unconformities. Special Publication of the International Association of Sedimentologists, vol. 18, p. 109-123.

Roca, X. A., 2007. Tectonic and eustatic controls on the allostratigraphy and depositional environments of the Lower Colorado Group (Upper Albian) central foothills and adjacent plains of Alberta, Western Canada Foreland Basin. Western University, Ontario, Canada. PhD Thesis. 432 pp.

Roy, K., Jablonski, D., and Valentine, J. W., 1994. Eastern Pacific molluscan provinces and latitudinal diversity gradient: No evidence for "Rappoport's rule": Proceedings of the National Academy of Sciences, vol. 91, p. 8871-8874.

Roy, K., Valentine, J. W., Jablowski, D., and Kidwell, S. M., 1996. Scales of climatic variability and time averaging in Pleistocene biotas: Implications for ecology and evolution, Trends in Ecology and Evolutions, vol. 11, p. 458-463.

Sageman, B. B., 1989. The benthic boundary biofacies model: Hartland Shale Member, Greenhorn Formation (Cenomanian), Western Interior, North America.

Palaeogeography, Palaeoclimatology, Palaeoecology, vol. 74, no. 1-2 p. 87-110.

Sarg, J.F., 1988. Carbonate sequence stratigraphy: In: Wilgus, C.K., Hastings, B.S., St. C. Kendall, C.G., Poasmentier, H.W., Ross, C.A., and Van Wagoner, J.C., (eds), Sea-level changes: An integrated approach, Society of Economic Paleontologists and Mineralogists, Special Publication No. 42, p. 155-181.

Sars, G. O., 1872. Undersògelser over Hardangerfjordens Fauna. Forhandlinger I Videnskasselskabet I Kristiania, vol. 1871, p. 246-255. 
Scarponi, D., and Kowalewski, M., 2007. Sequence stratigraphic anatomy of diversity patterns: late Quaternary benthic mollusks of the Po Plain, Italy. Palaios, vol. 22, no. 3, p. 296-305.

Schröder, C.J., 1986. Deep-water arenaceous foraminfera in the Northwest Atlantic Ocean. Dalhousie Univeristy, Halifax, Nova Scotia, Canada. PhD thesis $190 \mathrm{pp}$.

Schröder-Adams, C.J., Leckie, D.A., Bloch, J., Craig, J., McIntyre, D.J. and Adams, P.J., 1996. Paleoenvironmental changes in the Cretaceous (Albian to Turonian) Colorado Group of western Canada: microfossil, sedimentological and geochemical evidence. Cretaceous Research. vol.17, p. 311-365.

Schröder-Adams, C.J. and Pedersen, P. K., 2003. Litho and biofaces analysis of the Buckinghorse Formation: The Albian Western Interior Sea in Northeastern British Columbia. Bulletin of Canadian Petroleum Geology vol. 51, p. 234-252.

Scott, D. B., and Medioli, F. S., 1980. Quantitative studies of marsh foraminiferal distributions in Nova Scotia: Implications for sea level studies: Cushman Foundation for Foraminiferal Research, Special Publication No. 17, 58 pp.

Sliter, W. V., 1979. Cretaceous foraminifers from the north slope of Alaska. In: Ahlbrandt, T. S., (ed) Preliminary geologic petrologic and paleontologic results of the study of Nanushuk Group rocks, North Slope, Alaska United States Geological Survey Circular 794, p. 147-158.

Sliter, W. V., 1981. Albian foraminifers from the Lower Cretaceous Cristopher Formation of the Canadian Arctic Islands. Geological Survey of Canada, Bulletin 300 , p. 41-70.

Stelck, C.R., 1958. Stratigraphic position of the Viking Sand. Journal of the Alberta Society of Petroleum Geologists, vol. 6, p. 2-7.

Stelck, C.R., 1975. The Upper Albian Miliammina manitobensis Zone in northeastern British Columbia. In: W.G.E. Caldwell, (ed), The Cretaceous System in the Western Interior of North America. Geological Association of Canada Special Paper, 13, p. 251-275.

Stelck, C.R., 1991. Foraminifera of the middle to upper Albian transition (Lower Cretaceous), northeastern British Columbia. Canadian Journal of Earth Sciences, vol. 28 , p. 561-580.

Stelck, C.R. and Hedinger, A.S., 1976. Secondary cribation in Haplophragmium (foraminifera). Journal of Foraminiferal Research, vol. 6, p. 134-141.

Stelck, C.R. and Hedinger, A.S., 1983. Foraminifera of the lower part of the Sully Formation (upper Albian), northeastern British Columbia. Canadian Journal of Earth Sciences, vol. 20, p. 1248-1259. 
Stelck, C.R. and Koke, K.R., 1987. Foraminiferal zonation of the Viking interval in the Hasler Shale (Albian), northeastern British Columbia. Canadian Journal of Earth Sciences, vol. 24, p. 2254-2278.

Stelck, C. R. and Leckie, D. A., 1990. Biostratigraphy of the Albian Paddy Member (Lower Cretaceous Peace River Foramtion), Goodfare, Alberta. Canadian Journal of Earth Sciences, vol. 27, no. 9, p. 1159-1169.

Stelck, C. R., MacEachern, J. A., and Pemberton, S. G. 2000. A calcareous foraminiferal fanule from the upper Albian Viking Formation of the Giroux Lake and Kaybob North fields, northwestern Alberta: implications for regional biostratigraphic correlation. Canadian Journal of Earth Sciences vol. 37, p. 1389-1410.

Stelck, C.R. and Wall, J.H., 1955. Foraminifera of the Cenomanian Dunveganoceras Zone from Peace River area of western Canada. Research Council of Alberta, Report 70, $81 \mathrm{pp}$.

Stelck, C. R., Wall, J. H., Bahan, W. G. and Martin, L. J., 1956. Middle Albian Foraminifera from the Athabasca and Peace River drainage areas of Western Canada. Alberta Research Council Report 75, 59 pp.

Stott, D.F., 1968. Lower Cretaceous Bullhead and Fort St. John groups, between Smoky and Peace Rivers, Rocky Mountain foothills, Alberta and British Columbia. Geological Survey of Canada, Bulletin 152, 134 pp.

Stott, D.F., 1982. Lower Cretaceous Fort St. John Group and Upper Cretaceous Dunvegan Formation of the foothills and Plains of Alberta, British Columbia, District of MacKenzie and Yukon Territory. Geological Survey of Canada, Bulletin 328, 124 pp.

Stott, D. F., 1984. Cretaceous sequences of the foothills of the Canadian Rocky Mountains. In: Stott, D F. and Glass, D J., (eds), The Mesozoic of North America. Canadian Society of Petroleum Geologists, Memoir 9, p. 85-108.

Stritch, R. A., and Schröder-Adams, C. J., 1999. Foraminiferal response to Albian relative sea-level changes in northwestern and central Alberta, Canada. Canadian Journal of Earth Science vol. 36, p. 1617-1643.

Sutherland, G. D. and Stelck, C.R., 1972. Foraminifera from the Cretaceous Neogastroplites zone Moberly Lake, British Columbia. Bulletin of Canadian Petroleum Geology, vol. 20, p. 549-582.

Tappan, H., 1940. Foraminifera from the Grayson Formation of northern Texas. Journal of Paleontology, vol. 14, p. 93-126. 
Tappan, H., 1943. Foraminifera from the Duck Creek Formation of Oklahoma and Texas. Journal of Paleontology, vol.17, p. 476-517.

Tappan, H., 1951. Northern Alaska index foraminifera. Cushman Foundation for Foraminiferal Research Contributions, vol. 2, p. 1-8.

Tappan, H., 1957. New Cretaceous index Foraminifera from northern Alaska. United States National Museum, Bulletin 215, p. 201-222.

Tappan, H., 1960. Cretaceous biostratigraphy of northern Alaska. American Association of Petroleum Geologists Bulletin, 44, no. 3, p. 273-297.

Tappan, H., 1962. Foraminifera from the Arctic slope of Alaska; Part 3, Cretaceous Foraminifera. United States Geological Survey, Professional Paper 236-C, p. 91205.

Tibert. N. E., and Leckie, M. R., 1985. High-resolution estuarine sea level cycles from the late Cretaceous: Amplitude constraints using agglutinated foraminifera. Journal of Foraminiferal Research, vol. 34, no. 2, p. 130-143.

Tibert. N. E., and Leckie, M. R., 2004. High resolution estuarine sea level cycles from the Late Cretaceous: amplitude constraints using agglutinated foraminifera. Journal of Foraminiferal Research, vol. 34, no. 2, p. 130-143.

Then, D. R. and Dougherty, B. J., 1983. A new procedure for extracting foraminifera from indurated organic shale. Geological Survey of Canada, vol. 83-1B, p. 413414.

Tyagi, A., Plint, G. A. and McNeil, D. H., 2007. Correlation of physical surfaces, bentonites and biozones in the Cretaceous Colorado Group from the Alberta Foothills to southwest Saskatchewan, and a revision of the Belle Fourche Second White Specks formational boundary. Canadian Journal of Earth Sciences. vol. 44, p. 871-888.

Vail, P. R., 1984. Episodic and cyclic sedimentation. American Association of Petroleum Geologists, vol. 68, no. 4, p. 536-537.

Vail, P.R., 1987, Seismic sequence interpretation using sequence stratigraphy, part 1 Seismic stratigraphy interpretation procedure: in Bally, A.W., eds., Atlas of seismic stratigraphy: American Association of Petroleum Geologists Studies in Geology vol. 27, p. 1-10.

Van der Zwaan, G. J., Duijnstee, I. A. P., den Dulk, M., Ernst, S. R., Jannink, N. T. and Kouwenhoven, T. J., 1999. Benthic foraminifers: proxies or problems? A review of paleoecological concepts. Earth Science Reviews, vol. 46, no. 1-4, p. 213-236. 
Veizer, J., 2003, Isotopic evolution of seawater on geological time scales: sedimentological perspective, in Lentz, D.R., ed., Geochemistry of Sediments and Sedimentary Rocks: Evolutionary Considerations to Mineral Deposit-Forming Environments: Geological Association of Canada, GeoText 4, p. 53-68.

Wall, J.H., 1967a. Cretaceous foraminifera of the Rocky Mountains foothills, Alberta. Research Council of Alberta, Bulletin 20: 185 pp.

Wall, J.H., 1967b. Paleoecology of Cretaceous marine microfaunas in the Rocky Mountain Foothills of Alberta and British Columbia. In: Wall, J.H., (ed), Paleoenvironments of the Cretaceous seaway in the Western Interior. Colorado School of Mines, Golden Colorado, p. 173-196.

Warren, P. S., and Stelck, C. R., 1969. Early Neogastroplites, Fort St. John Group, western Canada. Bulletin of Canadian Petroleum Geology vol.17, p. 529-547.

Wickenden, R T. D. and Shaw, G., 1943. Stratigraphy and structure in Mount Hulcross Commotion Creek map area, British Columbia (summary account). Geological Survey of Canada, vol. 17, no. p. 17-32.

Wickenden, R. T. D., 1932. New species of foraminifera from the Upper Cretaceous of the prairie provinces. Transactions of the Royal Society of Canada, ser. 3, vol. 26, no. 4, p.127-132.

Wickenden, R. T. D., 1951. Some Lower Cretaceous sections on Peace River below the mouth of Smoky River, Alberta. Geological Survey of Canada, Paper 51-16 $47 \mathrm{pp}$.

Wignall, P. B., 1994. Black Shales. Oxford Monographs on Geology and Geophysics, vol. $30,127 \mathrm{pp}$.

Williams, G. K., 1958. Influence of the Peace River Arch on Mesozoic strata. Journal of Alberta Society of Petroleum Geologists, vol. 6, p. 74-81.

Williams, G.D. and Stelck, C.R., 1975. Speculations of the Cretaceous paleogeography of North America. In: W.G.E. Caldwell, (Editor), The Cretaceous System in the Western Interior of North America. Geological Association of Canada Special Paper, 13, p. 1-20.

Zhang, H., 2006. Allostratigraphy of the Shaftesbury Formation, Northern Alberta and northeastern British Columbia: response to eustatic and tectonic controls. University of Western Ontario. M. Sc. Thesis 237 pp. 
PLATES 


\section{PLATE 1}

Agglutinated taxa:

Figures 1, 2. Bathysipon brosgei Tappan. X40, 1 Hasler Creek PR-2006-C6, side view; 2 Deadhorse Meadows DHM-15-04, side view.

Figure 3. Psammosphaera sp. X40, Hasler Creek PR-2006-15, side view.

Figure 4. Saccammina alexanderi Loeblich and Tappan. X40, Halfway River PR-2006D10.

Figure 5. Saccammina globosa Crespin. X40, Moberly Lake Rd. PR-2006-F4, side view.

Figure 6. Ammodiscus mangusi Tappan. X40, Moberly Lake Rd. PR-2006-F3, side view.

Figures 7, 8. Reophax minuta Tappan. X40, 7 Deadhorse Meadows DHM-34-04, side view; 8 Halfway River PR-2006-D9, side view.

Figure 9, Reophax texanus Cushman and Waters. X40, Moberly Lake Rd. PR-2001-J3, side view.

Figures 10, 11. Reophax troyeri Tappan. X40, 10 Moberly Lake Rd. PR-2001-H11, side view; $11 \mathrm{Mt}$. Belcourt Belct-7, side view.

Figures 12, 13. Reophax vasiformis Chamney. X40, 12 Moberly Lake Rd, PR-2001-H9, side view; 13 Moberly Lake Rd, PR-2001-H4, side view.

Figures 14-19. Miliammina manitobensis Wickenden, X40, 14 and 15 Deadhorse Meadows DHM-13-04, opposite sides; 16 and 17 Hasler Creek PR-2006-C9, opposite sides; 18 and 19 Hasler Creek PR-2006-C19, opposite sides. 

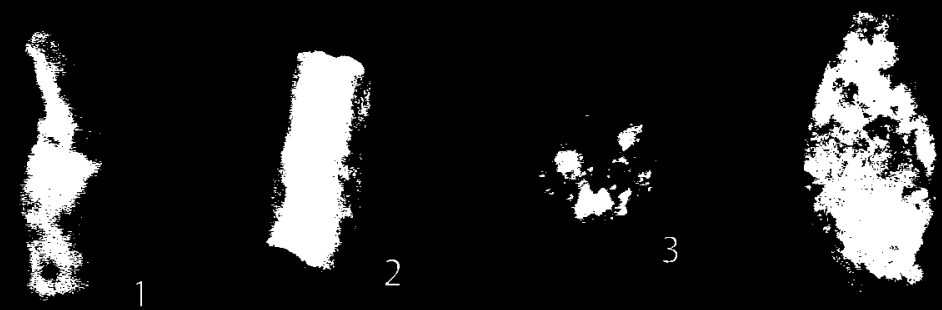

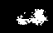

称

की मैक 3

6
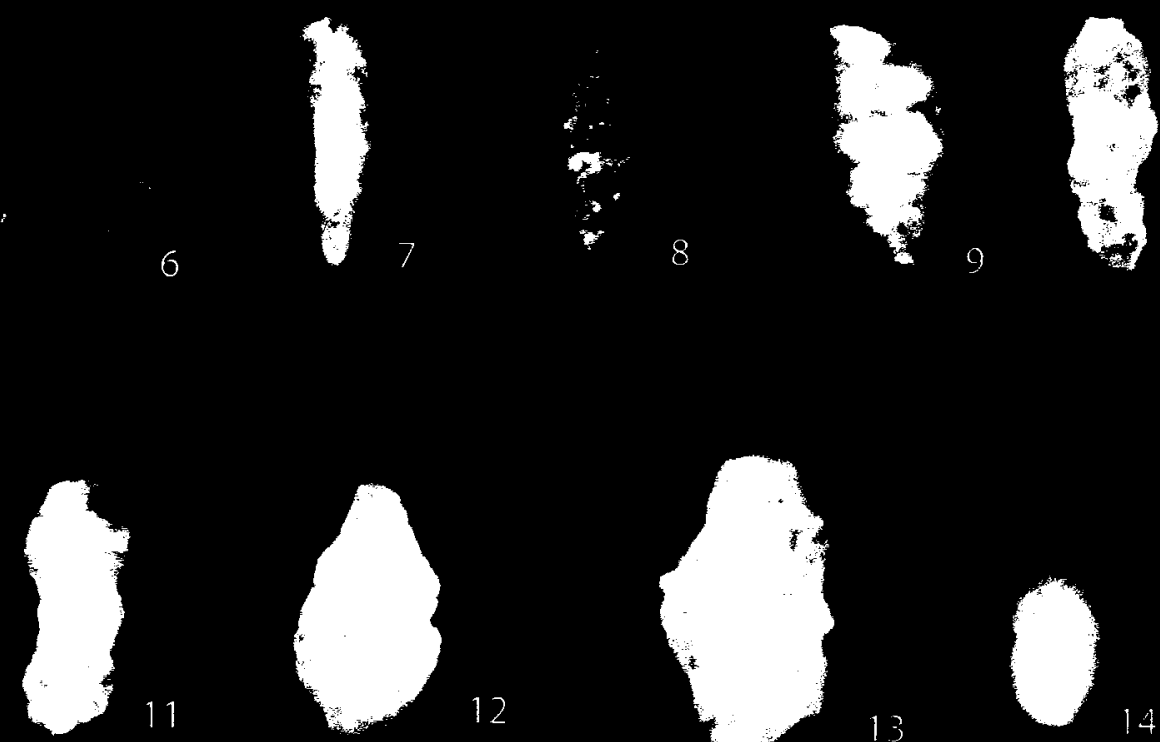

12

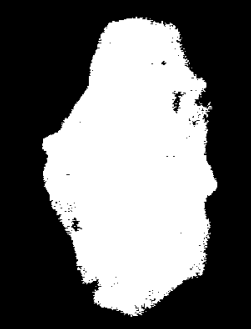

13
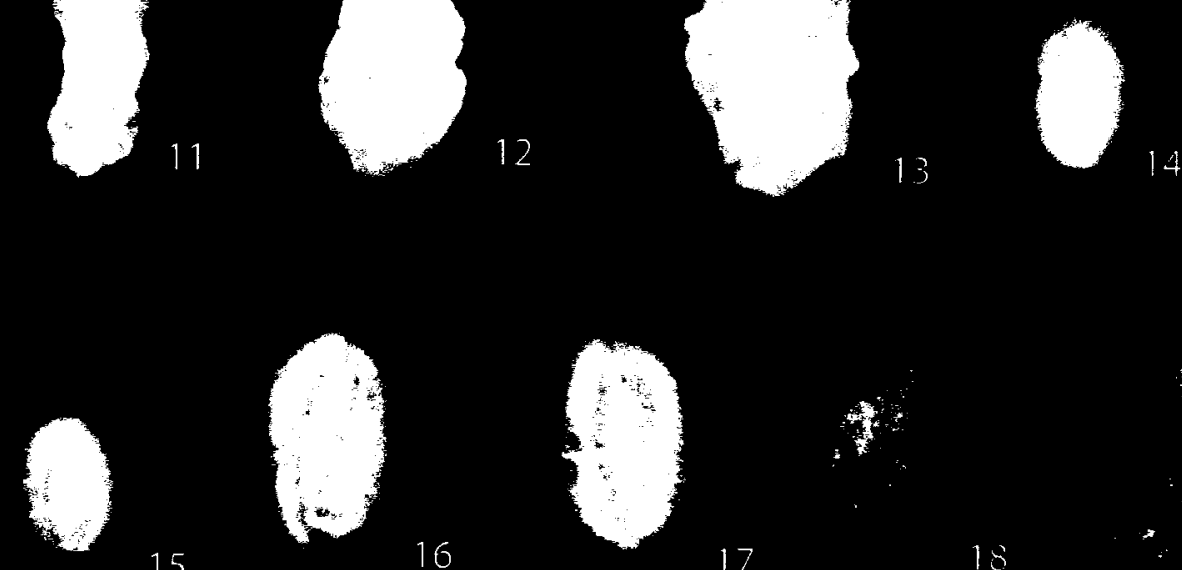

15

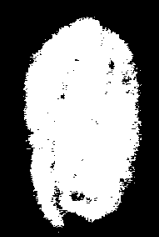

16
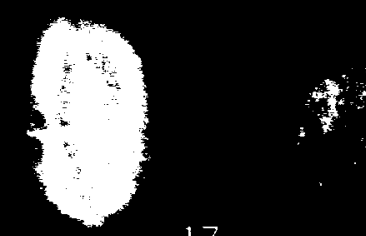

17

18 


\section{PLATE 2}

Figures 1, 2. Miliammina sproulei Nauss. X40, 1 Nickerson Creek NC-6-04, side view; 2 Deadhorse Meadows DHM-34-04, side view.

Figure 3. Psamminopelta bowsheri. X40, Hasler Creek PR-2006-15, side view.

Figures 4, 5. Haplophragmoides collyra Nauss. X40, Halfway River, PR-2006-D9, opposite side views.

Figures 6, 7. Haplophragmoides gigas Cushman. X40. Moberly Lake Rd. PR-2001-G3, opposite side views.

Figures 8, 9. Haplophragmoides gilberti Eicher. X40, Moberly Lake Rd. PR-2006-G3, opposite side views.

Figures 10, 11. Haplophragmoides kirki Wickenden. X40, Moberly Lake Rd. PR-2001$\mathrm{H} 2$, opposite side views.

Figures 12, 13. Haplophragmoides linki Nauss. X40, Moberly Lake Rd. PR-2006-F3, opposite side views.

Figures 14-17. Haplophragmoides multiplum Stelck and Wall. X40, 14, 15; Moberly Lake Rd. PR-2006-F4, opposite side views; 16, 17; Mt. Belcourt Belct-7, opposite side views.

Figures 18-21. Haplophragmoides postis Stelck and Wall. X40, 18, 19; Moberly Lake Rd, PR-2001-H9, opposite side views; 20, 21; Moberly Lake Rd, PR-2001-H4, opposite side views. 


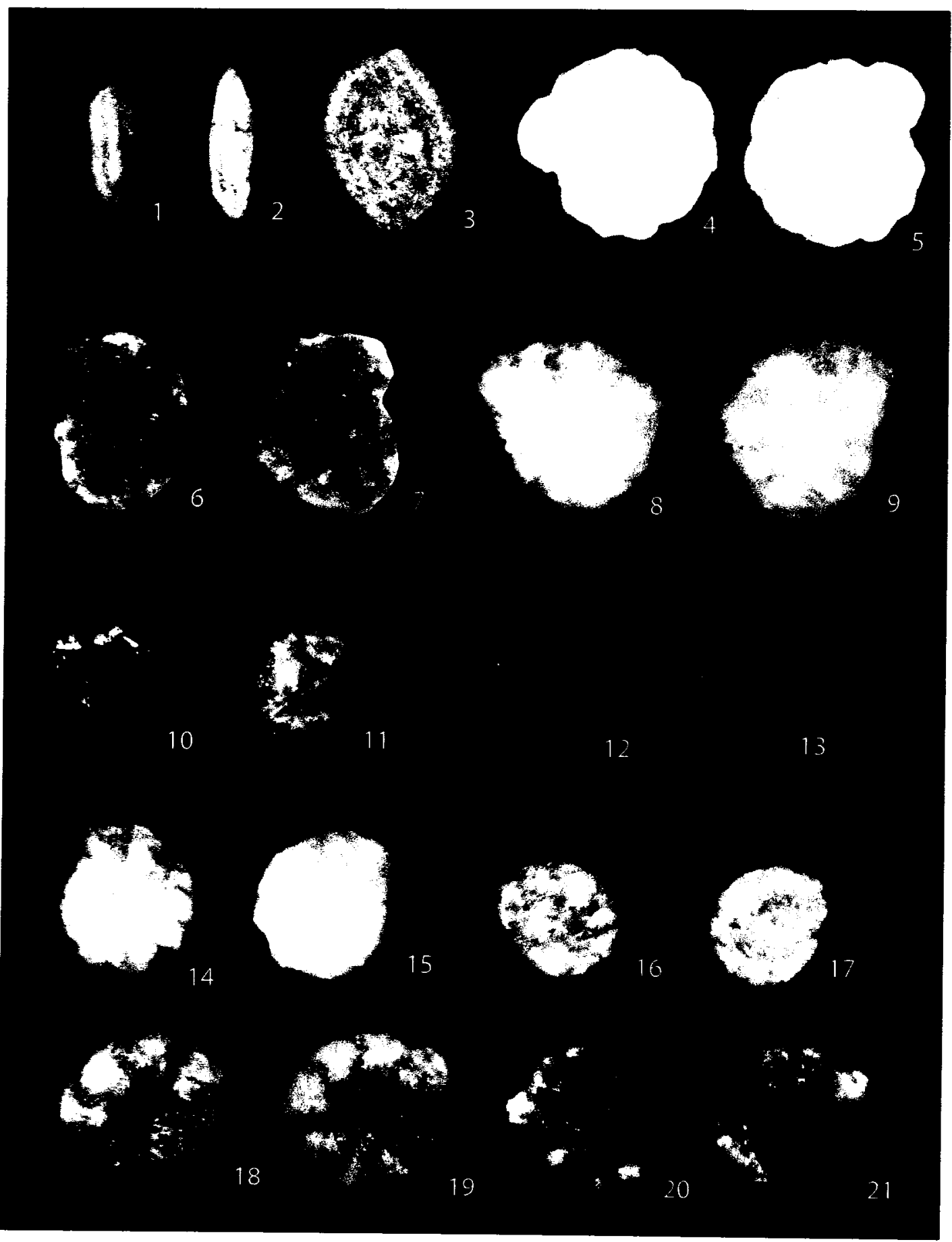




\section{PLATE 3}

Figures 1-4, Haplophragmoides postis Stelck and Wall X40, 1, 2 Moberly Lake Rd.

PR-2001-J1, opposite side views: 3, 4 Deadhorse Meadows DHM-30-04, opposite side views.

Figures 5, 6. Haplophragmoides postis goodrichi Sutherland and Stelck X40, Deadhorse Meadows, DHM-9-04, opposite side views.

Figures 7, 8. Haplophragmoides topagorukensis Tappan X40, Nickerson Creek, NC-406, opposite side views.

Figures 9, 10. Ammobaculites gravenori Stelck and Wall X40, Deadhorse Meadows, PR2006-I10, opposite side views.

Figures 11-14. Ammobaculites fragmentarius Cushman X40, 11, 12 Deadhorse Meadows DHM-21-04, opposite side views; 13, 14 Halfway River, PR-2006-D7, opposite side views.

Figures 15, 16. Ammobaculites petilus Eicher X40, Halfway River, PR-2006-D10, opposite side views.

Figures 17, 18. Ammobaculties tyrrelli Nauss X40, Deadhorse Meadows, DHM-23-04, opposite side views. 

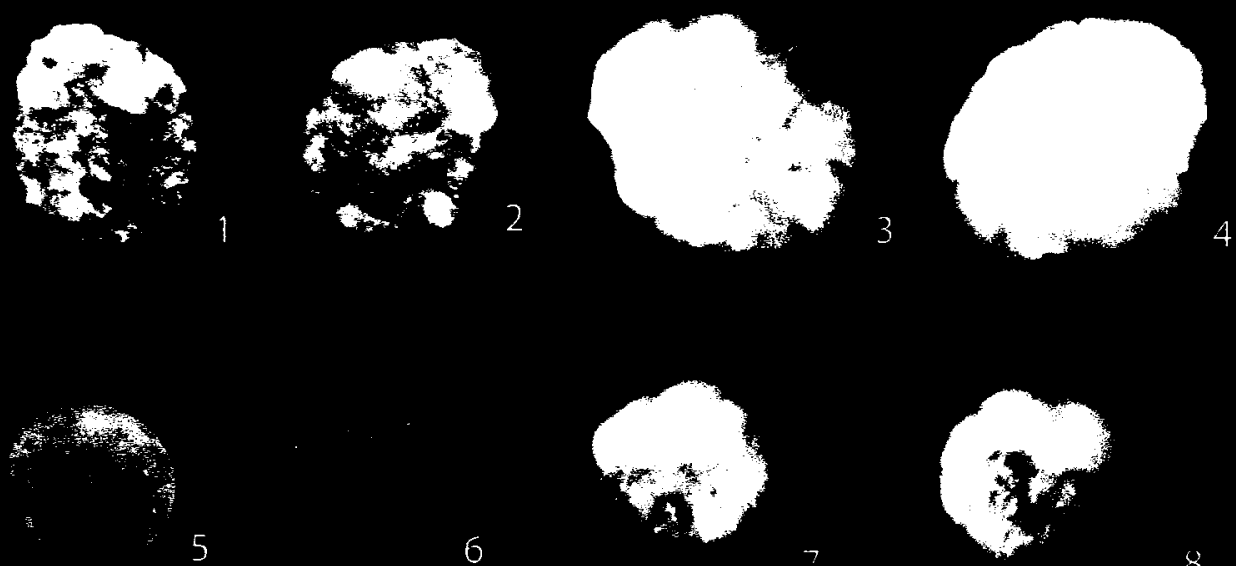

8
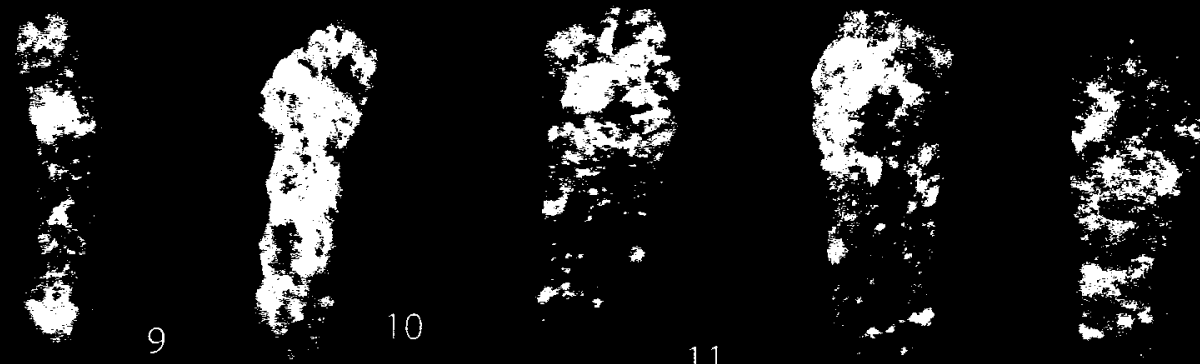

9

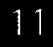

12

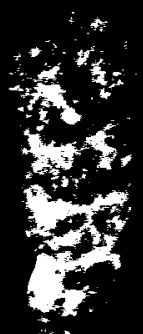

14
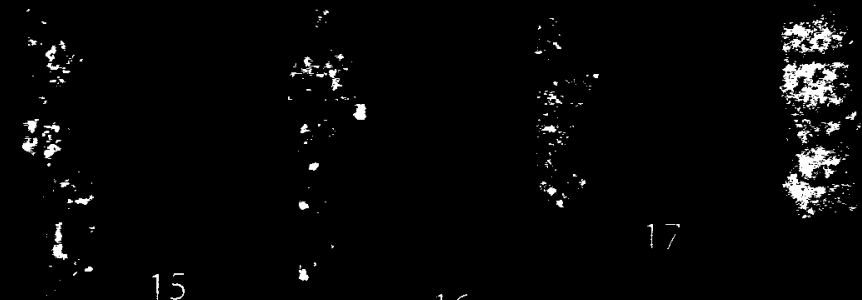

18

16 


\section{PLATE 4}

Figures 1, 2. Ammobaculites tyrrelli Nauss X40, Halfway River, PR-2006-D5 opposite side views.

Figures 3, 4. Ammobaculites wenonahae Tappan X40, Sulphur River, SR-6-04, opposite side view.

Figures 5-10. Haplophragmium swareni Stelck and Hedinger X40, 5, 6 Moberly Lake Rd. PR-2006-F3, opposite side view; 7, 8 Deadhorse Meadows, DHM-33-04, opposite side views; 9, 10, Deadhorse Meadows DHM-32-04, opposite side views.

Figure 11, Textulariopsis minuta Berthelin X40, Deadhorse Meadows, DHM-7-04.

Figures 12, 13. Trochammina rutherfordi Stelck and Wall X40, Sulphur River, SR-5-04, 12 spiral view, 13 umbilical view.

Figures 14, 15. Trochammina umiatensis Tappan X40, Sulphur River, SR-6-04, 14, umbilical view, 15 spiral view.

Figure 16. Verneuilinoides borealis Tappan X40, Nickerson Creek, NC-1-06.

Figures 17, 18. Verneuilinoides fischeri Tappan X40, Moberly Lake Rd. PR-2006-F3, opposite side views.

Figures 19, 20. Verneuilinoides perplexus Loeblich X40, Deadhorse Meadows, PR2006-13, opposite side views. 


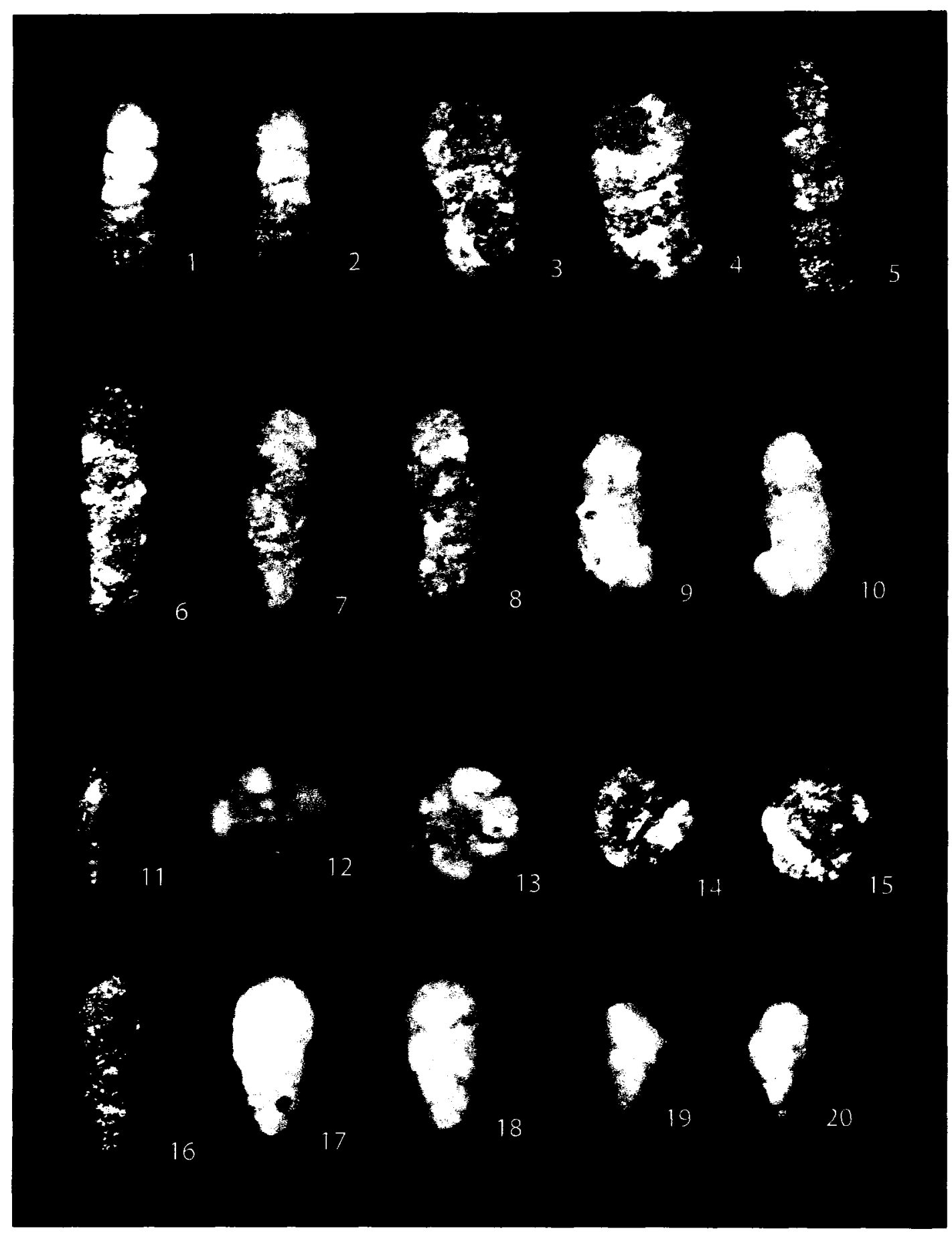




\section{PLATE 5}

Figures 1. Gaudryina canadensis Cushman X40, Moberly Lake Rd. PR-2001-G4, opposite side views.

Figures 2, 3. Gaudryina irenensis Stelck and Wall X40 Deadhorse Meadows, PR-2006I17, opposite side views.

Figures 4-7. Verneuilina canadensis Cushman X40, 4,5. Moberly Lake Rd. PR-200-H7, opposite side views; 6. Deadhorse Meadows, DHM-15-04; 7. Moberly Lake Rd. PR-2001-G3.

Figures 8, 9. Gravellina chamneyi Stelck X40, Hasler Creek, PR-2006-C6, opposite side views.

\section{Calcareous taxa:}

Figures 10, 11. Lenticulina macrodisca (Reuss) Tappan X40 Mt. Belcourt, Belct 9, opposite side views. 


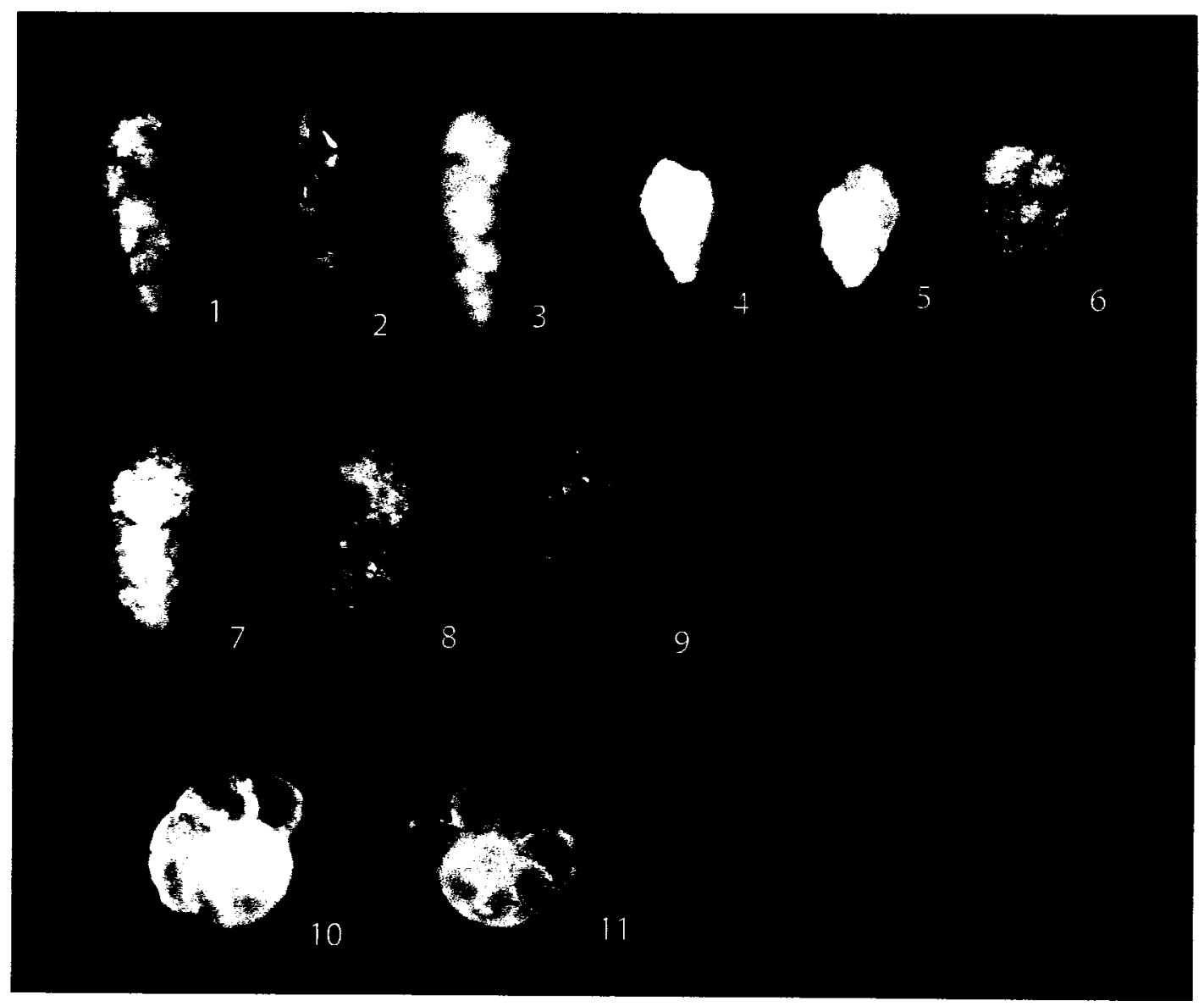




\section{APPENDIX}




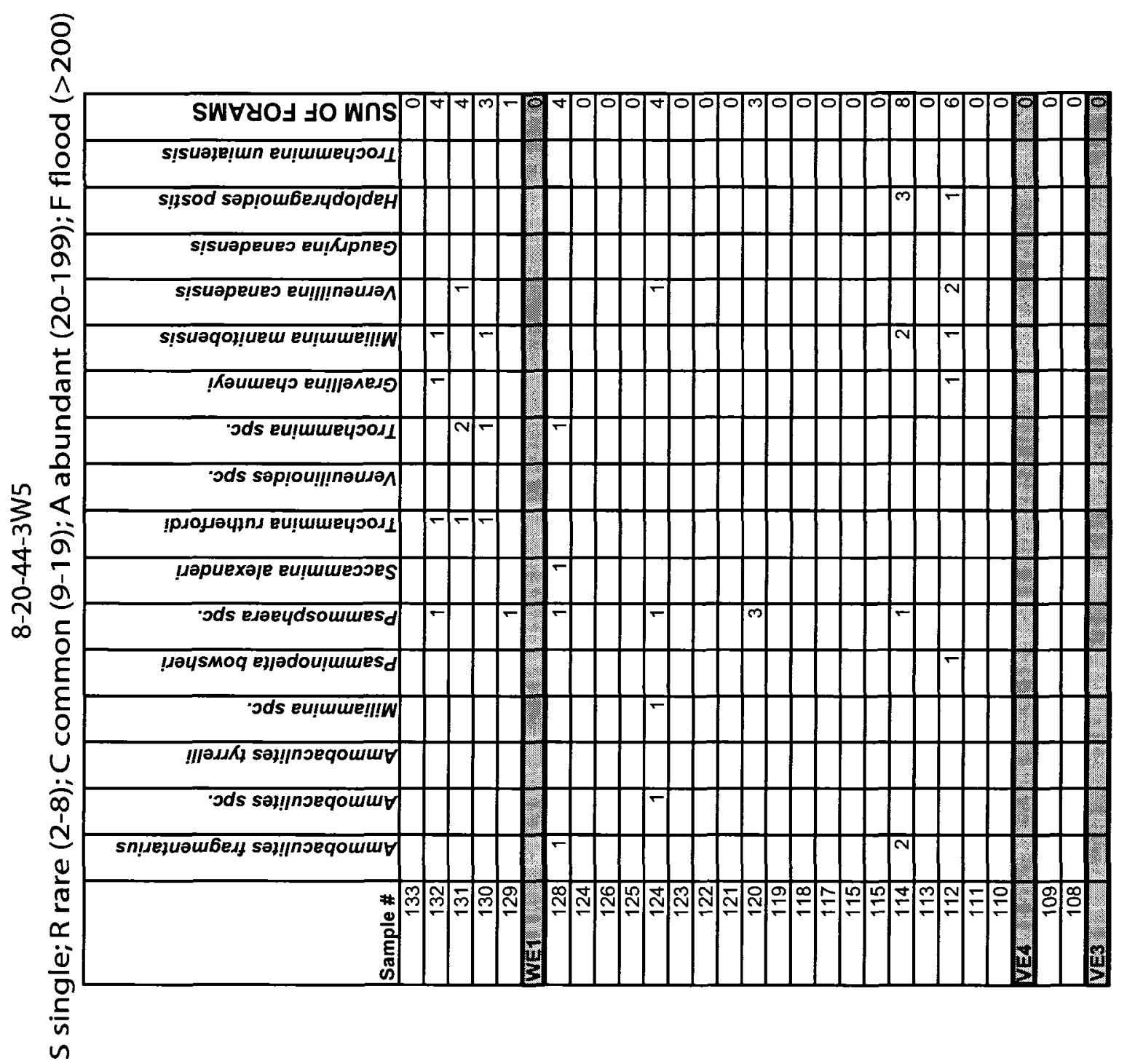




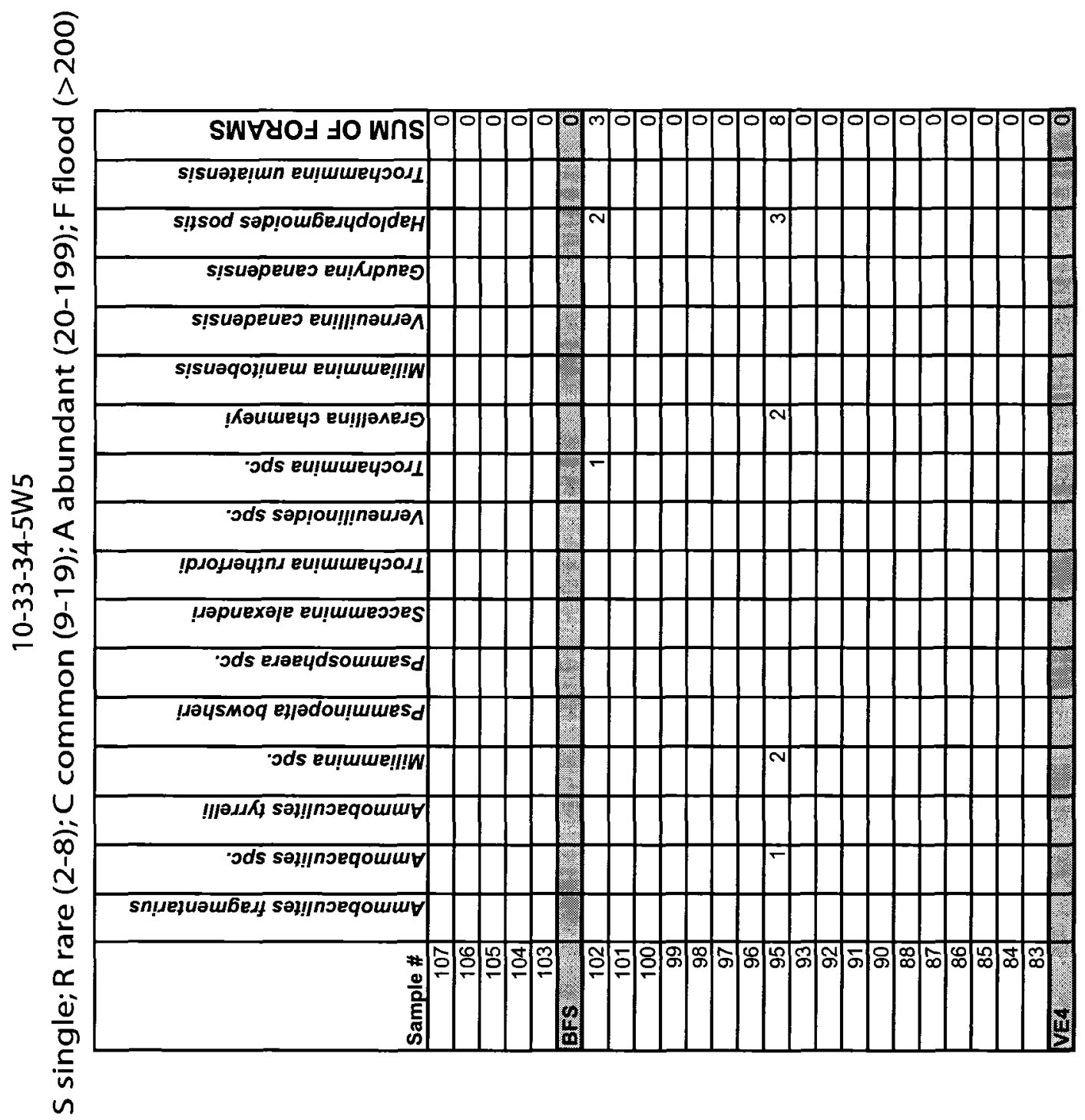




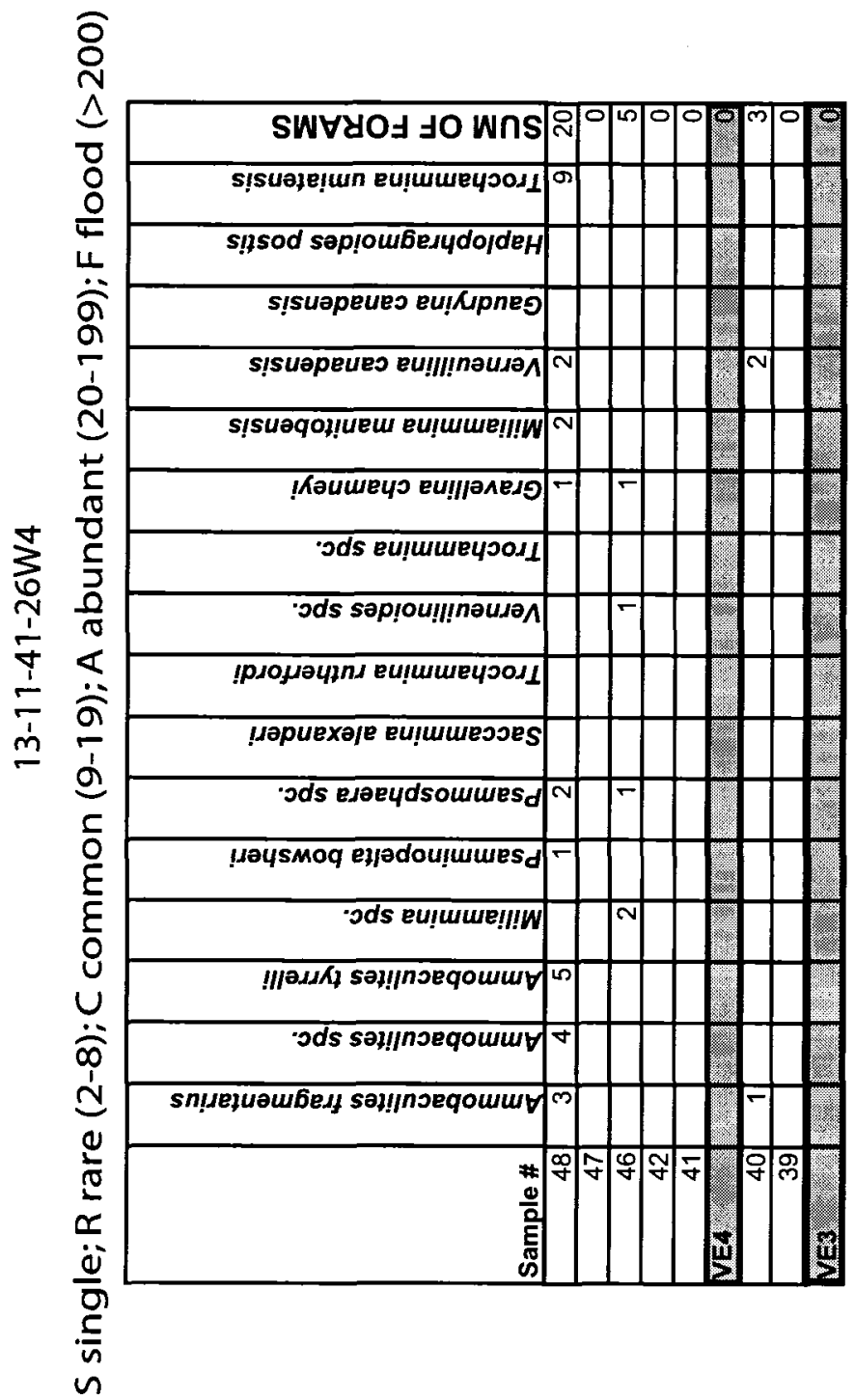




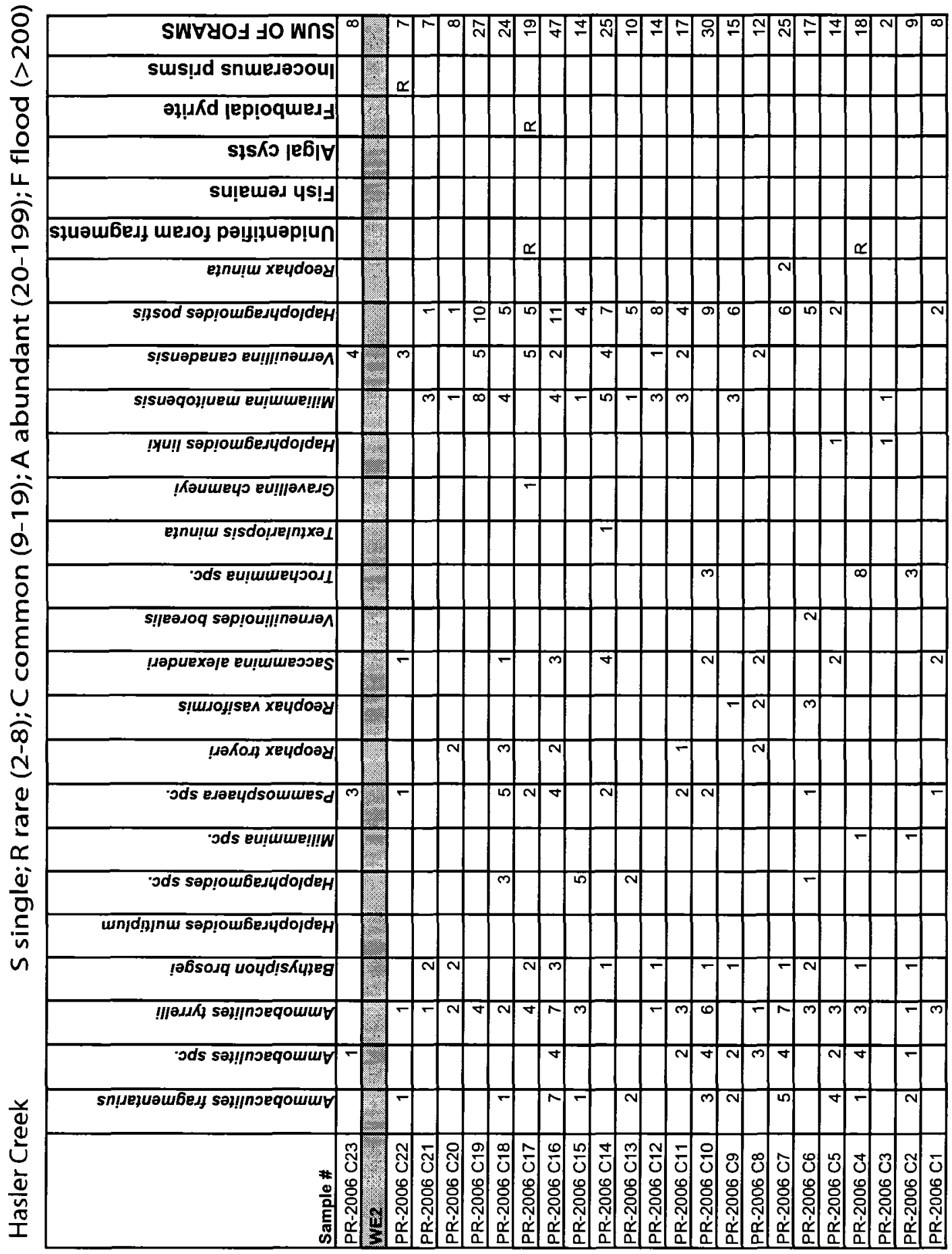




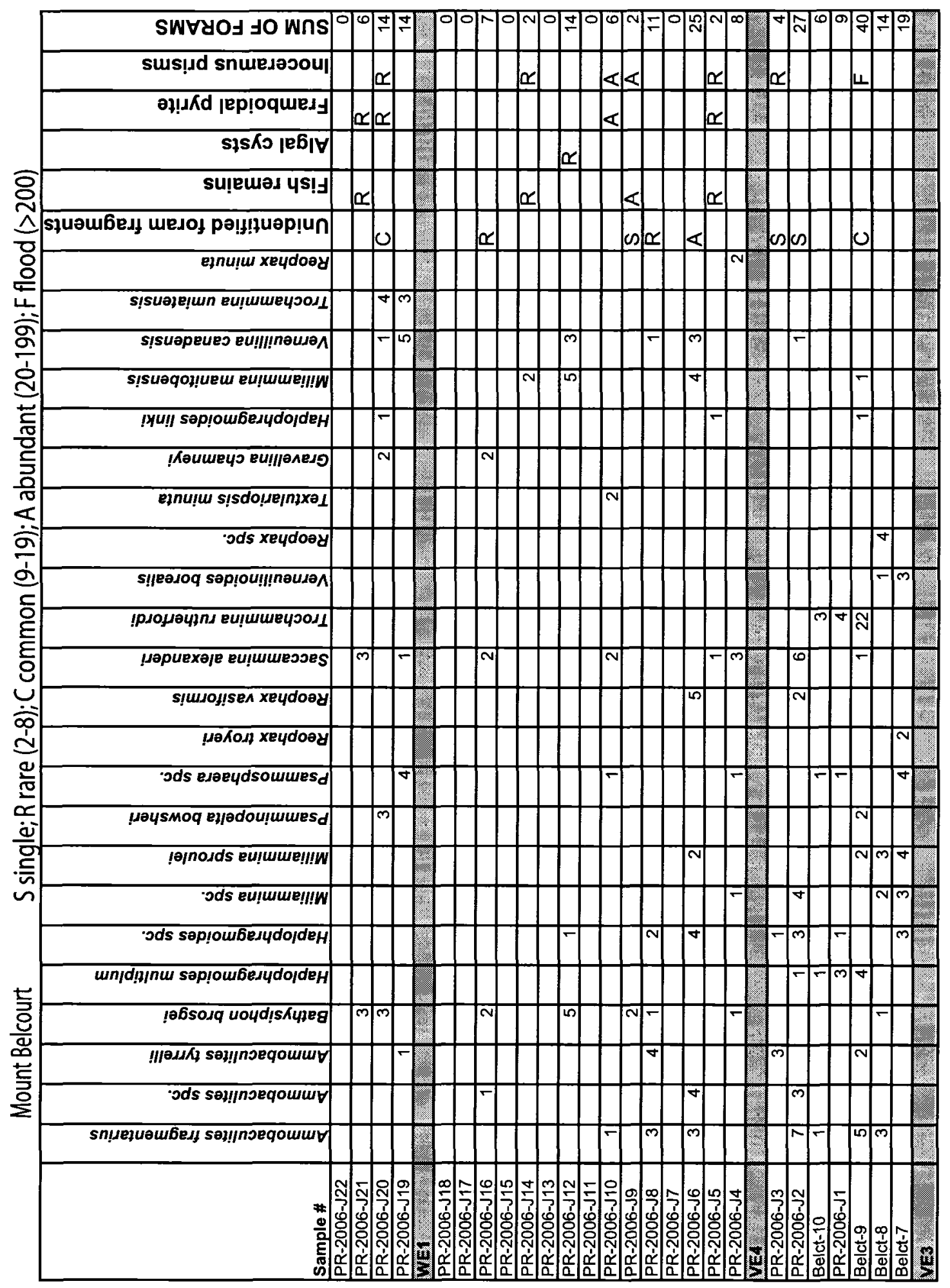




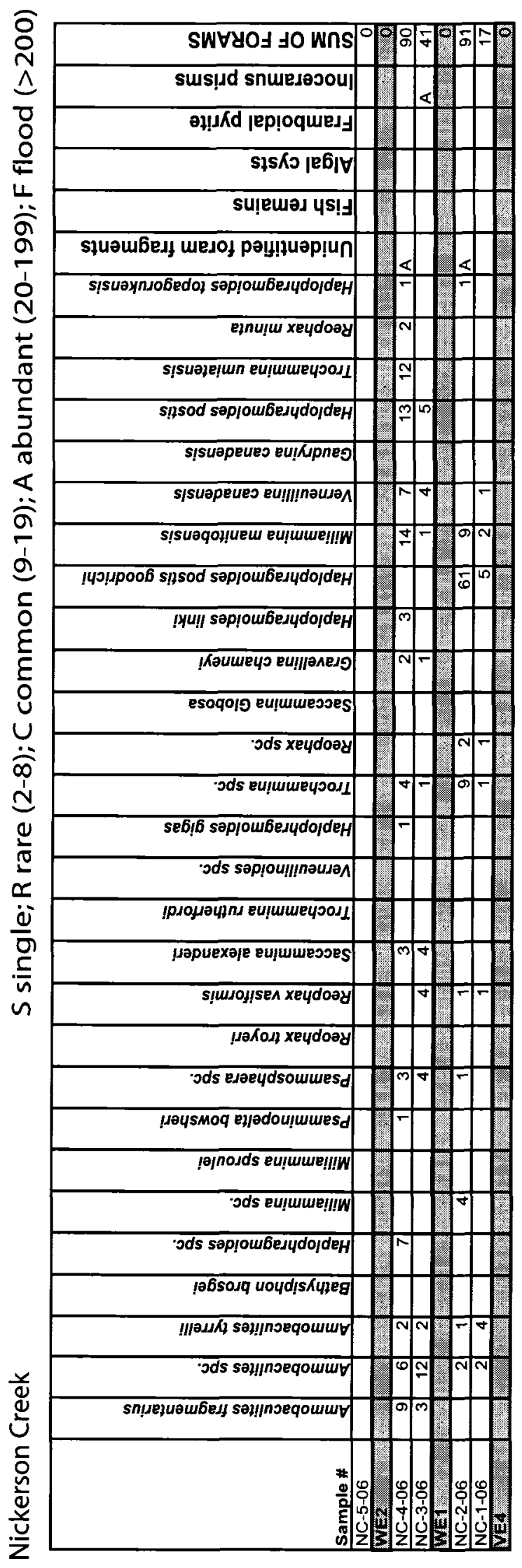

Reproduced with permission of the copyright owner. Further reproduction prohibited without permission. 


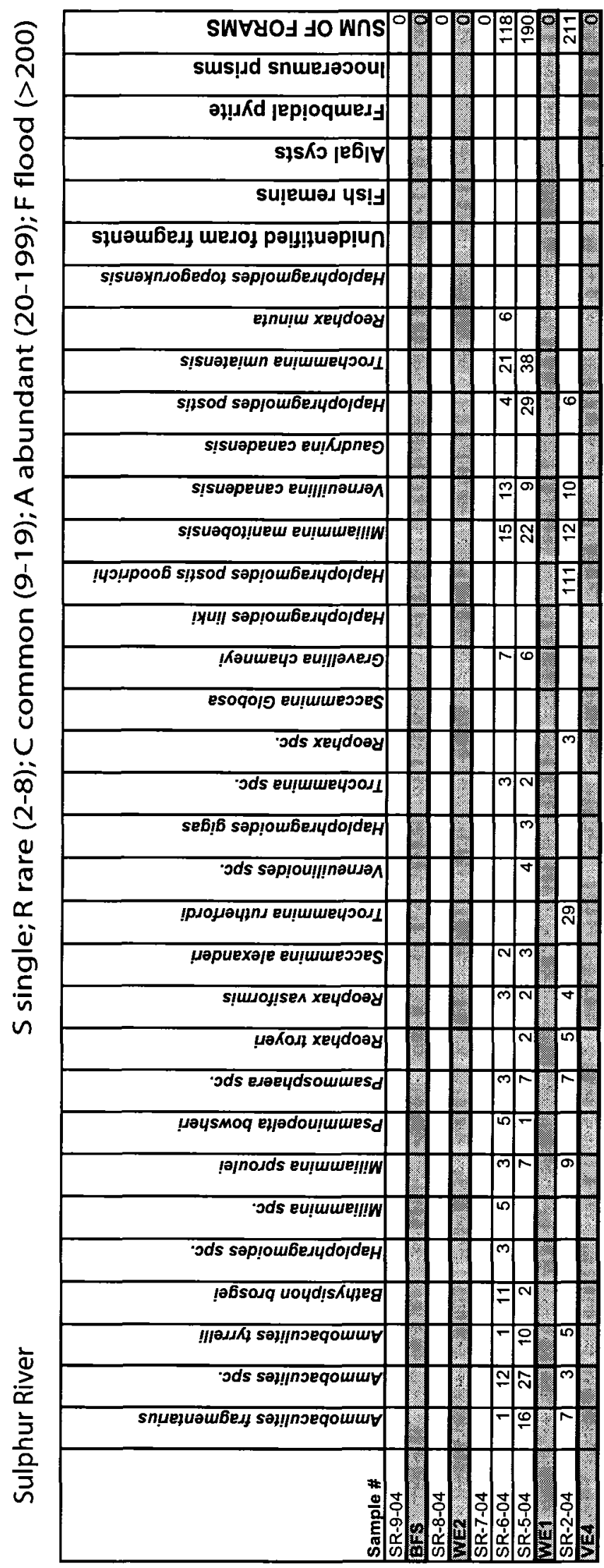

Reproduced with permission of the copyright owner. Further reproduction prohibited without permission. 


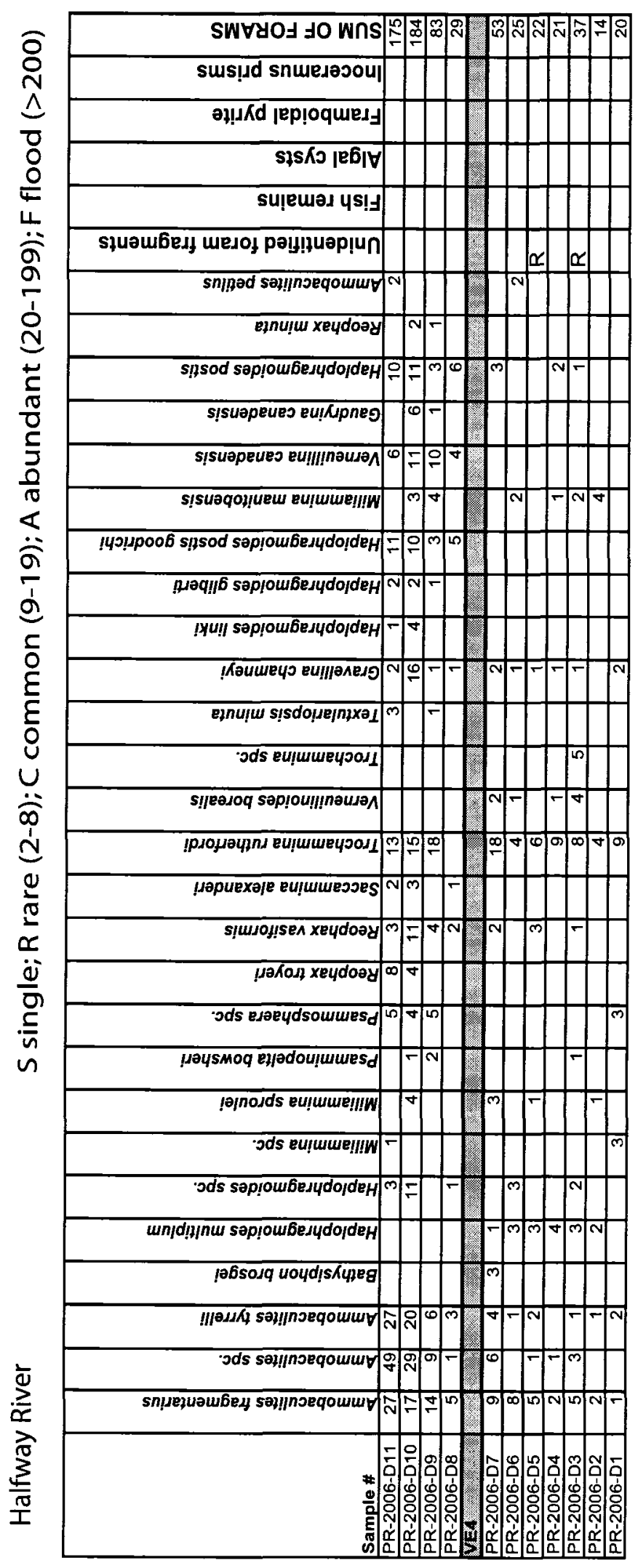




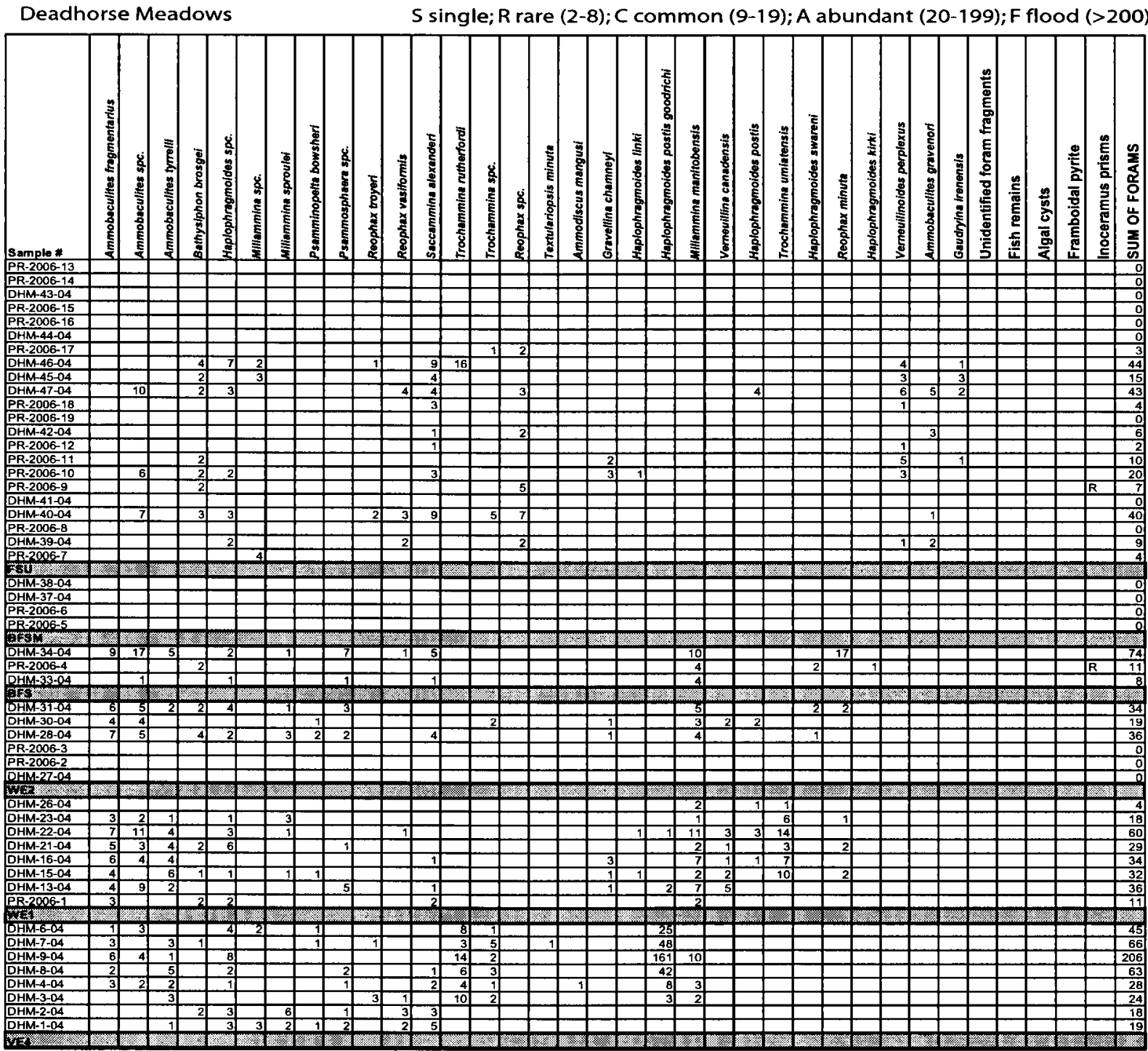


